\title{
Imageria e poéticas de representação da paisagem urbana nas redes \\ Didiana Prata
}

\section{Dissertação de Mestrado}

apresentada à Faculdade de Arquitetura e Urbanismo

da Universidade de São Paulo para a obtenção

do título de Mestre em Arquitetura e Urbanismo.

Área de Concentração: Projeto Espaço e Cultura

Orientador: Profa. Dra. Giselle Beiguelman

São Paulo

2016 
Autorizo a reprodução e divulgação total ou parcial deste trabalho, por qualquer meio convencional ou eletrônico,

para fins de estudo e pesquisa, desde que citada a fonte.

E-MAIL DA AUTORA: didiana@pratadesign.com.br

\section{Agradecimentos}

O desenvolvimento deste trabalho contou com a colaboração e generosidade de amigos, familiares, instituições e diversas pessoas.

Em primeiro lugar, gostaria de agradecer à minha orientadora Giselle Beiguelman por ter me acolhido na FAU-USP. Pelo seu entusiasmo com a pesquisa, sua contribuição e estímulo durante o percurso, sobretudo nas transformações e evoluções do projeto. Sua companhia e astral foram contagiantes.

À profa. Clice Mazilli, pela convivência e disponibilidade em conversar sobre a

construção de narrativas imagéticas e devires, ao longo de um semestre intenso na FAU DESIGN, onde fui monitora PAE na disciplina "Processos de Criação e Design Visual".

Aos professores Artur Rozestraten e Guilherme Wisnik, pelas contribuições preciosa na banca de qualificação, importantes para a delimitação do recorte da pesquisa.

Aos colegas da pós-graduação, pela interlocução permanente, troca de referências, links, contribuindo para a formação de uma rede. Em especial, Francesco Perrota Bosch, Lucas Bambozzi, Lucas Girard, Giovanna Casimiro, Artur Codeiro, Ana Ottoni, Vanessa Poitena, Luciana Santos e Silas Marti.

Ao Cacá (prof. Carlos Falci) e seu bom papo mineiro, durante meu retiro no Matutú. Pela sua contribuição precisa, cirúrgica, no momento certo da dissertação.

Aos artistas mapeados nesta pesquisa que acreditam na potencialidade da imagem mobile, se interessaram e acompanharam parte do projeto e cederam suas imagens para minhas apropriações: Everton Ballardin, Ivan Padovanni, Miriam Homem de Melo, Roberto Wagner, Juan Esteves, Danny Zappa e H.Dimantas.

Às amigas Catherine Otondo e Marcella Faria por todas as conversas e incentivo no mergulho acadêmico. Às pratas da casa, Luisa Prat, Beatriza Dorea, Lilian Og e Sofia Toi, pela paciência e pela ajuda na finalização dos volumes. E à Silvana pela solidariedade e atenta revisão.

Aos meus pais que sempre me incentivaram a fazer o que eu quisesse e torcem incondicionalmente por mim.

Ao Jero, meu amor. À Teresa, Tarsila e Antonio, nossos filhos. Sem vocês sou pá furada. 


\section{Resumo}

Esta dissertação tem como foco central a investigação acerca das narrativas visuais produzidas por câmeras celulares e veiculadas nas redes sociais, particularmente no Instagram. Explora como a tecnologia dos dispositivos móveis, somada ao movimento do corpo e do olho, contribui para uma nova estética de produção de imagens do cotidiano. 0 estudo tem como contexto a cidade de São Paulo e também explora as novas formas de documentar e de se relacionar com o espaço urbano, a partir da produção e veiculação de imagens na internet.

A pesquisa se concentra no viés poético das imagens produzidas, mediadas e veiculadas no Instagram e investigará o contexto e a natureza das imagens das redes sociais, que se apresentam de forma fragmentada, em um processo de publicação contínuo, em um scroll vertical infinito, na tela do usuário do aplicativo. Explorará as possibilidades de construção de linguagem, na chave da artemídia, e seus respectivos atributos tecnológicos e estéticos. Investigará paralelamente como se dá a edição e subjetivação dessas narrativas, construídas em tempo real, indagando qual o papel do autor, do curador e do editor quando o processo se torna colaborativo.

A imagem mobile será pensada por meio de imagens, a partir de um ensaio autoral: uma compilação de narrativas reunidas no caderno Imageria urbana, realizadas com imagens mobile a partir de apropriações e edições coletivas ou individuais, organizadas pelos tagueamentos de dados algorítmicos, pelos sinais "\#" (hashtags precedidas da palavra-chave) e por pins de geolocalização. Essa publicação constitui simultaneamente o objeto de estudo teórico e prático desta pesquisa e representa alguns lugares da cidade de São Paulo por meio da estética de dados. A partir desse material - e suas imbricaç̃oes interdisciplinares - oferecemos os subsídios teóricos para aprofundarmos na linguagem poética das narrativas visuais das redes.

\section{Palavras-chaves:}

imagem mobile, narrativas visuais, Instagram, redes sociais, paisagem urbana, mapeamentos, net art, estética de banco de dados 


\section{Abstract}

Imagery and poetic representations of urban landscape in social media networks

This dissertation aims at investigating visual narratives produced by mobile cameras and posted on social networks, specifically Instagram. Exploring how mobile device technology, coupled with the movement of body and eye, contributes to new aesthetic of production on everyday imaging. The city of São Paulo comes as the study's context and explores new ways to register and to relate to the urban space stemming from the production and posting of images online.

The research focuses on poetic bias of the produced images mediated and shown on Instagram and investigates the context and nature of the images on social networks, which are presented in a piecemeal fashion, in a continuous process of posting through endless vertical scroll on the app's user screen. The work will explore the possibilities of language construction from artmedia point of view, and its respective technological and aesthetic attributes. In addition, it will investigate how editing and subjectivity of these narratives take place, built in real time, inquiring the role of the author, of the curator and of the editor when the process becomes collaborative.

The mobile image will have images brought through an authorial essay; a compilation of narratives gathered in the notebook Urban Imagery, made with mobile images from collective or individual publications and appropriations, organized from algorithm data tagging by the "\#" (hashtag preceded by keyword) and pins of geolocation. Such publication is both the theoretical and practical object of this research study and represents some places of the city of São Paulo through the data aesthetics. From this material - and its interdisciplinary overlaps - we provide the theoretical basis to deepen into the poetic language in visual narratives of networks.

\section{Key words:}

Mobile image, visual narrative, Instagram, social network, urban landscape, mapping,

net art, database aesthetics 


\section{Sumário}

VOLUME 1

Introdução

A imagem mobile:

Contexto, natureza e singularidade

1.1. Multiculturalismo, tecnologia e consumo

1.2. Narrativa radicante

1.3. Superprodução de imagens e estetização do cotidiano

1.4. Imageria: novas potencialidades e funções da imagem

1.5. Natureza tecnológica e numérica

1.6. Redes informacionais

1.7. A tela como interface

\section{VOLUME 2}

Arqueologia das narrativas visuais:

Do Atlas Mnemosyne (Warburg, 1924-1929) a

On Broadway (Manovich, 2014)

2.1. Derivas contemporâneas: estética do deslocamento

2.2. A Instamatic de Smithson e o Instagram de "qualquer um"

2.3. Narrativas imagéticas impressas e digitais

2.4. Let's participate and play

2.5. Artemídia na história da arte

2.6. Um atlas atual e radicante

2.7. A linguagem híbrida e o espaço cíbrido
VOLUME 3

Imageria urbana: \#x

Caderno de imagens

\section{VOLUME 4}

Narrativas nas redes:

Poéticas no fluxo midiático

4.1. Imagens feitas para viajar

4.2. A arte como metalinguagem 10

4.3. A habilidade do metadado de agregar imagens

4.4. \# (hashtag) $+\mathrm{X}$ (palavra-chave)

4.5. A volta do texto. 0 paradoxo da era cibernética

4.6. Criando narrativas a partir de novos contextos e dados

4.7. A frase-imagem

4.8. Estética coletiva e diluição do autor

Considerações finais

Referências 


\section{Introdução}

A investigação sobre a poética das narrativas visuais nas redes sociais parte da premissa da contaminação dos campos da arte, da tecnologia, da comunicação e dos territórios (o espaço geográfico e o ciberespaço) nos quais essas imagens são produzidas e veiculadas. Para compreender a singularidade dessas narrativas construídas com imagens mobile - imagens captadas "em movimento", potencializadas pelos recursos tecnológicos das câmeras e dos aplicativos dos aparelhos celulares nos quais são produzidas, mediadas e veiculada - foi preciso explorar as intersecções entre esses campos.

Constatamos o quanto as raízes dessa nova prática estética estão imbricadas com as manifestações da cultura urbana contemporânea e com os movimentos políticos e sociais de um mundo cada vez mais globalizado, conectado em redes informacionais. Assumimos o viés tecnológico, cultural e artístico dessa prática para investigarmos as relações entre representação e subjetivação do espaço a partir dessas narrativas fragmentadas, diluídas no fluxo midiático das redes.

\section{Questão fundamental}

O foco central desta pesquisa é a poética da narrativas visuais com imagens mobile. Qual a natureza dessa imagem e a singularidade dessa manifestação artística, imbricada no campo da artemídia? E como essa imagem pode ganhar outras potencialidades inerentes aos dispositivos tecnológicos das redes, possibilitando novas manifestações e significações formais, estéticas e comunicacionais?

Investigaremos especificamente como os recursos do aplicativo Instagram, tais como o uso de palavras-chaves precedidas de \# (hashtags) e pins de georreferenciação (GPS), são determinantes no processo de formação das camadas narrativas; como esses dados algorítmicos dão visibilidade às imagens, em novos formatos, deslocando-as para outros contextos além daquele no qual foram originalmente captadas ou produzidas.

Há vários desdobramentos relacionados à questão central e destacamos quatro pontos que guiaram a investigação da pesquisa:

- Apropriação e desinstitucionalização das narrarivas visuais nas redes: a contaminação de esferas individuais e coletivas configura uma nova estética coletiva e transdiscursiva?

- A imagem mobile dentro de um contexto de artemídia: como a produção de linguagem nas redes está atrelada à imagem numérica, ao texto e às estratégias de uso de dados algorítmicos?

- De que modo a estética das redes representa a paisagem urbana contemporânea?

\section{Iconografia das redes como metodologia}

O caderno Imageria urbana: \#x é um registro das narrativas das redes, ao modo de "O turista aprendiz" de Mario de Andrade nos anos 20, o caderno de suas viagens etnográficas pelo Nordeste. Entretanto, a publicação reúne registros das incursões da autora pelo Instagram, espaço no qual ela se apropria dos registros das viagens imagéticas de outrem, das poéticas de representação da cidade de São Paulo, para construir uma imageria urbana por meio de um grande banco de dados digital. É uma publicação impressa - com viés mais artístico e curatorial cujo corpo narrativo desencadeou o processo de investigação desta pesquisa. A formulação das questões fundamentais se deu a partir dessas imagens, e todo o processo de investigação baseou-se nos ensaios reunidos nessa edição.

Essa publicação tece um diálogo permanente com as referências teóricas da pesquisa, organizadas em quatro capítulos, conectados entre si. A narrativa escrita da dissertação procura responder às questões problematizadas pelos ensaios visuais do caderno. E vice-versa. 


\section{A estrutura da dissertação}

No capítulo 1 "A imagem mobile" investigamos o contexto multicultural e social do homem contemporâneo e sua relação estetizante com o cotidiano pelo prisma "radicante" de Bourriaud (2011). Associamos consumo, tecnologia e produção de linguagem no século XXI a partir das contribuições de Lipovetsky e Serroy (2014), Foster (2014) e Rancière (2005). E traçamos um paralelo com a produção e distribuição de imagem com dispositivos móveis.

A partir desse panorama de estetização do cotidiano, que Rancière (2005) denomina a "partilha do sensível do qualquer um", passamos a investigar especificamente a natureza da imagem mobile. Como paradigma teórico assumimos o uso do termo imagérie de Rancière (2013), traduzido como "imageria". 0 autor insere a linguagem da imagem atual, do fluxo das redes e das mídias no conceito de um novo "regime de imagéité": "As imagens são operações: relações entre um todo e as partes, entre uma visibilidade e uma potência de significação e de afeto que lhe é associada, entre as expectativas e aquilo que vem preenchê-las." (RANCIÈRE, 2013, p.11-12). Adotamos a palavra "imageria" no título por dois motivos: primeiramente por ela revelar a natureza da imagem mobile, uma imagem que pertence a este novo regime de imagens das redes, a esta imageria. Em segundo lugar pela associação direta que fazemos de "imageria"com "imaginário", revelando a natureza onírica e subjetiva das narrativas da pesquisa.

Utilizaremos o termo "imagem mobile", em vez da denominação corrente "fotografia mobile", pois assumimos não só suas características metamórficas (dentro do novo regime de imageria de Rancière), mas também o caráter móvel e numérico dessa imagem em permanente deslocamento. Aprofundaremos essa discussão a partir de Couchot (2003).

Beiquelman (2011) e Bastos (2009) tratam do contexto das redes e do uso de dispositivos móveis (especificamente da câmera do celular e dos aplicativos de captação, mediação e distribuição de imagem), ressaltando suas características tecnológicas e vocação para agenciamentos da net art. A questão da tela como interface das narrativas mobile também é contemplada no capítulo inicial.

No capítulo 2, "Arqueologia das narrativas visuais: do Atlas Mnemosyne (Warburg, 1924-1929) a On Broadway (Manovich, 2014)", abrangemos um grande arco temporal de diferentes expressões artísticas cujos agenciamentos se aproximam das narrativas produzidas e publicadas no Instagram. Partimos do conceito debordiano de deriva e da experiência do caminhante e sua apreensão estética da paisagem, tratada por Careri (2013).

Iniciamos com o Atlas Mnemosyne de Aby Warburg, cujo trabalho é referência atemporal para a arte contemporânea (GRAU, 2011; DIDI-HUBERMANN, 2013), Os trabalhos de Ed Ruscha e Robert Smithson realizados nos anos 60 e 70 servem de referência de artistas visuais que lidam com mapeamento, fotografia, paisagem urbana e reprodução técnica. Além disso, alinham-se com a produção bem mais atual de artistas cujos agenciamentos partem da apropriação de imagens captadas na internet, no Google ou no Flickr, do colecionismo digital. Destacamos os alemães Joachim Schmid e Michael Wolf, o holandês Erik Kessels e a americana Dina Kelberman, com o trabalho "I am Google", iniciado em 2011, ainda em andamento. E, por fim, apresentamos um artista fundamental para a pesquisa, Lev Manovich, especificamente a obra On Broadway, visualizada em um aplicativo. A partir do estudo de padrões estéticos de produção de imagem na rede, o artista relaciona, em um sistema próprio criado em seu laboratório de pesquisa, dados algorítmicos da cidade (geolocalização, número de fotos publicadas no Instagram e Twitter, entre outros) para representar a cidade por meio dessa estética do banco de dados.

Os ensaios de Mary Flanagan e Christiane Paul na coletânea Context providers: conditions of meaning in media arts (2011) tratam especificamente do contexto desses jogos narrativos na chave da artemídia e travam um diálogo importante entre 
Imageria e poéticas de representação da paisagem urbana nas redes

os meios de produção (cultural e tecnológico) e de veiculação (produtos reproduzidos em série, impressos ou digitais) na produção de linguagem contemporânea.

O capítulo 3, "Imageria urbana: \#x", como já comentado, traz o caderno de ensaios narrativos e pode ser apreciado fora da ordem dos volumes teóricos.

O último capítulo, "Narrativas nas redes: poéticas no fluxo midiático", concentra as especificidades das narrativas visuais criadas com imagens mobile, tais como a interdependência entre a poética dessas imagens e o meio tecnológico do dispositivo no qual são produzidas. Trataremos da dependência da imagem ao código escrito - para seu reconhecimento como informação arquivada na rede (BEIGUELMAN, 2003; WENDT, 2014) - e de como os tagueamentos e dados algorítmicos potencializam as construções de muitas camadas narrativas, criando uma miríade de possibilidades de representações poéticas em diferentes contextos de visualização (DIAMOND, 2011; PAUL, 2011; VESNA, 2007). Discutiremos também a estética das redes, a partir da defesa das imagens em baixa resolução, das "imagens feitas para viajar" (STEYERL, 2009), e a diluição da autoria.

Por fim, relacionamos o ensaio de imageria urbana e sua singularidade poética aplicada à representação da paisagem urbana. Sua potência como linguagem, produzida por "qualquer um", por cidadãos que compartilham novos modos de ver, de usar e de subjetivar o espaço urbano à luz da estética mobile.
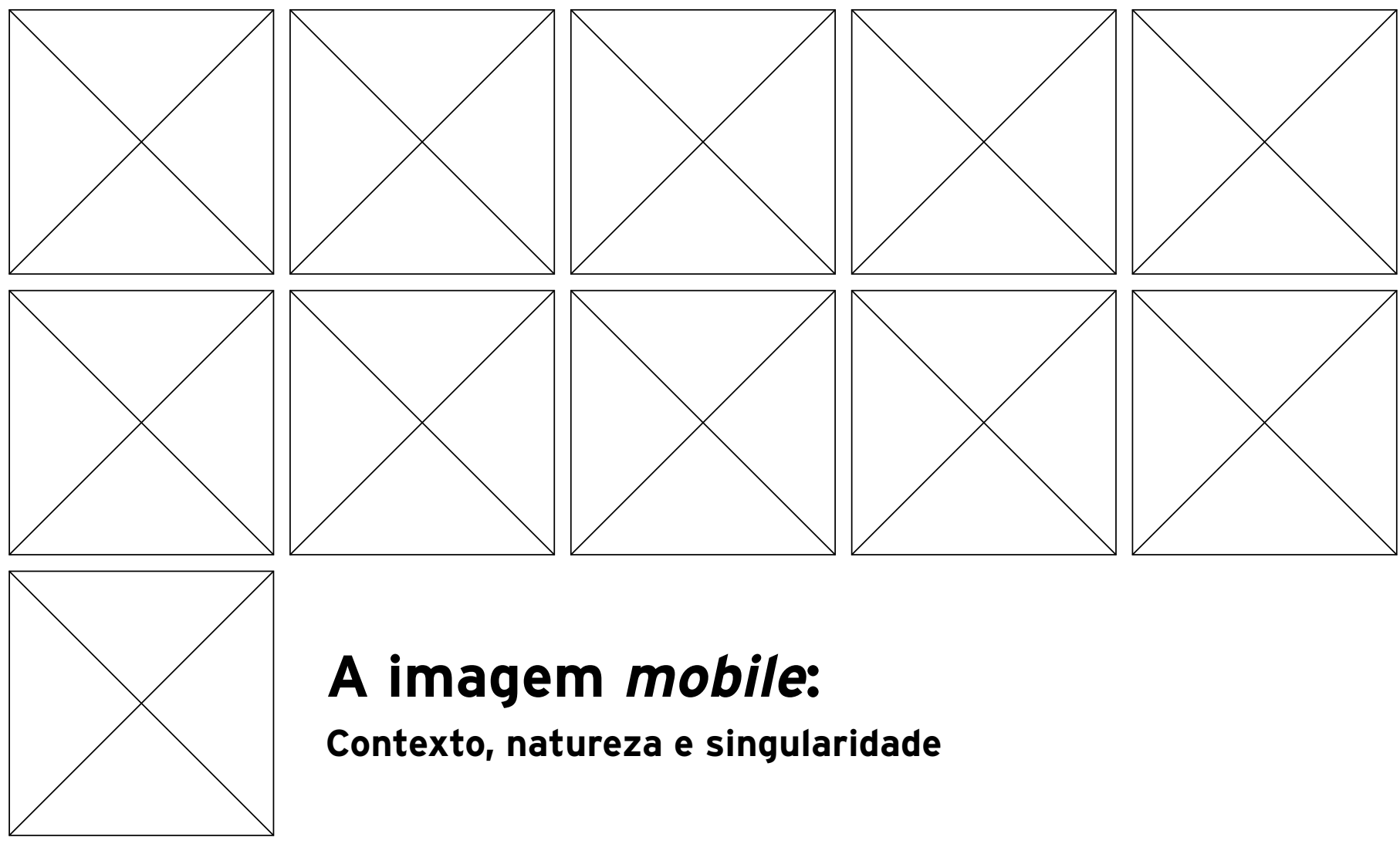

A imagem mobile:

Contexto, natureza e singularidade
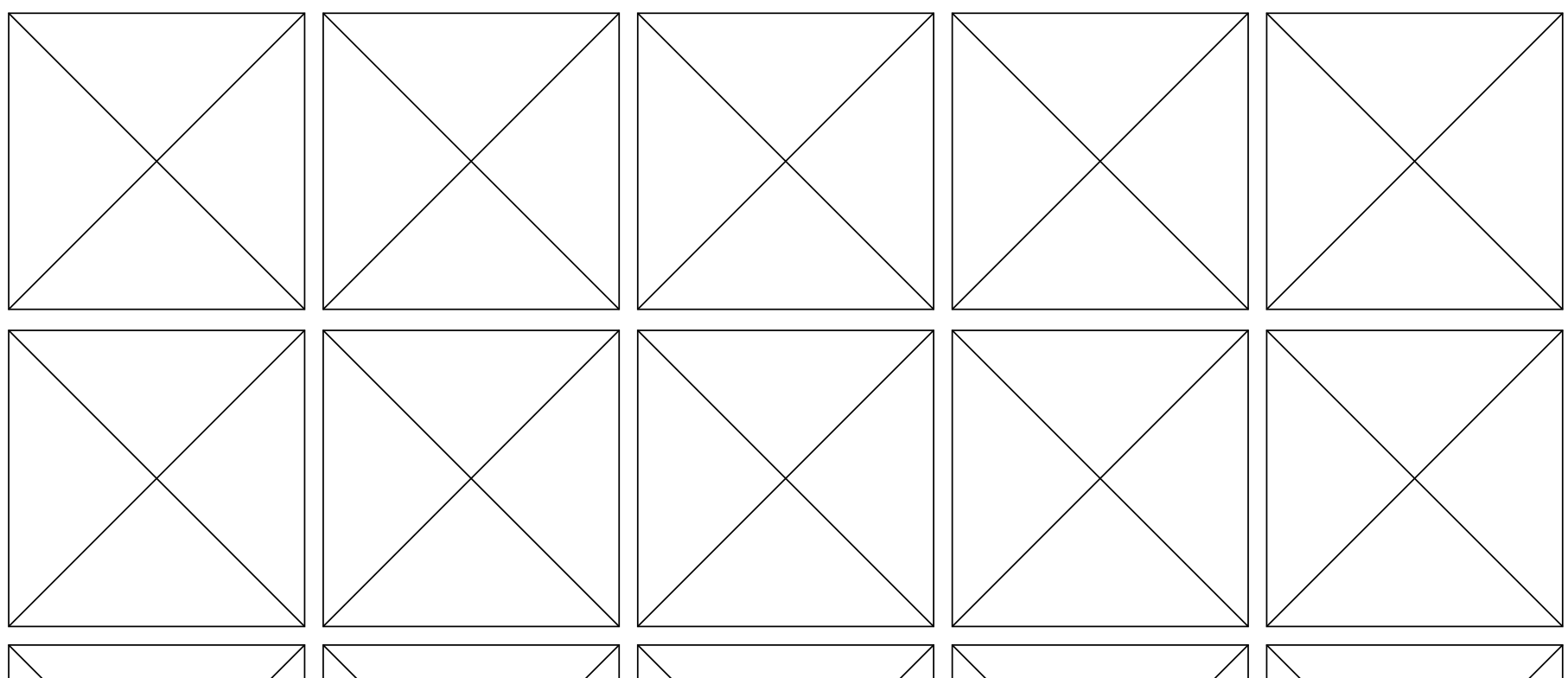
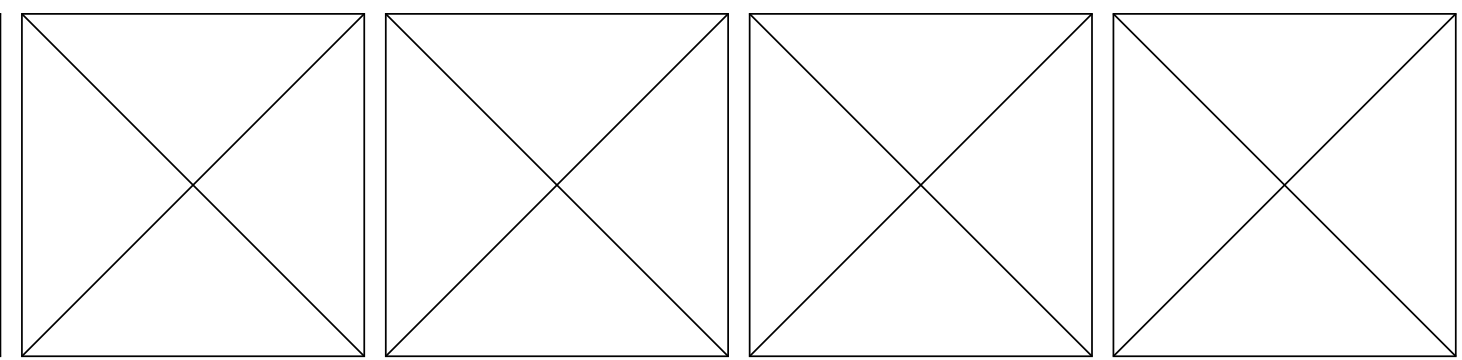
O uso da tecnologia e a produção de imagens estão incorporados no cotidiano do homem contemporâneo. Trabalhamos, nos conectamos com a família, nos conectamos socioculturalmente, nos politizamos, trocamos afetos (e desafetos) e participamos e ativamos as redes sociais com nossas manifestações de diversas naturezas. As fronteiras entre a vida off-line e a vida on-line parecem não existir, estão borradas, e nós, cidadãos, habitamos espaços "cíbridos" - neologismo utilizado por Beiguelman (2003) para dar conta das interpenetrações entre redes on e off-line.

Problematizar a singularidade da imagem produzida com dispositivos móveis exige primeiramente entender o contexto cultural e tecnológico no qual esta produção de linguagem está inserida. Qual a natureza desta imagem, suas características funcionais, formais e estéticas? Como classificar essa fotografia, uma imagem potencializada desde sua origem pelo uso customizado da tecnologia dos smartphones, na qual ela é produzida e mediada? Quais são as regras do jogo desses "aparelhos fotográficos", no sentido flusseriano, manipulados por "funcionários", homens que brincam com o aparelho e agem em função dele (FLUSSER, 1985)?

Nessa perspectiva, este capítulo apresenta um panorama da realidade multicultural na qual vivemos e produzimos linguagem e se apoia em algumas referências teóricas para responder às perguntas feitas acima, tendo sempre como perspectiva a poética das narrativas visuais construídas com imagens mobile produzidas por dispositivos móveis, mais precisamente, por câmeras celulares.

A discussão sobre como a globalização em seus aspectos econômicos, políticos e culturais impactou a produção artística do século XXI será feita pela chave da arte radicante de Nicolas Bourriaud (2011) e por meio de Lipovetsky e Serroy (2015).

Aprofundaremos as potencialidades da imagem mobile, no contexto de superprodução de imagens nas redes, a partir de dois conceitos fundamentais do filósofo e teórico francês Jacques Rancière. 0 primeiro diz respeito à estetização do cotidiano e à produção de linguagem do qualquer um: a "partilha do sensível", conforme livro homônimo do autor (2005). O segundo, "o novo regime de 'imagéité'", descrito em $O$ destino das imagens (2013), explica as novas formas e funções das imagens atuais.

Abordaremos a natureza tecnológica da imagem mobile a partir de Couchot (2003). E as novas manifestações de linguagem das redes sem fio no ciberespaço, esse novo lugar habitado por nós no qual a veiculação da imagem mobile está inserida, serão vistas a partir das referências de Nomadismos tecnológicos, volume organizado por Giselle Beiguelman e Jorge La Ferla (2011). A relação do uso de dispositivos móveis com a ressignificação dos lugares e territórios urbanos, tratada por Marcus Bastos em "Mapeamento incompleto de algumas geografias celulares" (2010), complementará essa reflexão.

A mobilidade do homem contemporâneo - inserido na globalização econômica e cultural, de fluxos migratórios e de produção de linguagem veiculada em tempo real - permite a construção de novos imaginários, novas experimentações. É dentro desse contexto que está inserido o autor, o artista e também editor e produtor das imagens mobile.

Bourriaud (2013) enxerga a globalização sob uma perspectiva estética. E vai buscar na ciência, especificamente na botânica, a imagem de raiz para desenvolver a teoria da estética radicante. Parte das raízes culturais para conceituar os novos enraizamentos multiculturais da arte contemporânea. A raiz seria o modernismo. As vanguardas artísticas do século XX são como movimentos de poda de galhos inúteis, de subtrair, eliminar e reiniciar a partir de uma nova fundação libertadora. Ele aposta que a modernidade atual se reinventará rejeitando a má solução do enraizamento identitário e a padronização dos imaginários decretados pela 
globalização econômica: "Os criadores de hoje baseiam-se em uma arte RADICANTE - epíteto que designa um organismo capaz de fazer brotar suas próprias raízes e de agregá-las à medida que vai avançando." (BOURRIAUD, 2011, p.20).

\section{Multiculturalismo, tecnologia e consumo}

Para Bourriaud, a obrigação territorial não faz parte da manifestação cultural contemporânea. As correntes pop, como referência a uma manifestação crítica à produção e ao consumo de massa, guardavam uma relação mais temporal entre a arte e o mundo e tinham um tempo para se desenvolver e se fazer notar. Estamos sujeitos a um conjunto de entidades "efêmeras", à precariedade da durabilidade dos produtos, dos modismos, das marcas.

Esse universo é também retratado por Bauman, que define o período dessa efemeridade da indústria e do consumo como modernidade líquida', e por Lipovestsky em A estetização do mundo - Viver na era do capitalismo artista (2014).

Lipovetsky e Serroy propõem discutir o domínio estético nesses tempos de expansão mundial da economia de mercado, em que os meios de produção e a distribuição industrial e cultural passam de universos completamente separados para universos completamente imbricados. A partir de uma visão hibridista de arte e consumo, na era da estetização da economia e do cotidiano denominada por eles capitalismo artista, os autores consideram a tecnologia como o grande motor para a interdependência do design, dos bens de consumo, do usuário/ consumidor, da arte e da economia.

É interessante associar a interdependência do design aos bens de consumo des-

O termo "líquido" é usado por Zygmunt Bauman em Modernidade líquida (2001) como metáfora para descrever a presente época da história moderna: "os fluidos não fixam espaç̧o nem prendem o tempo não se atêm a uma forma específica, ocupam um espaço apenas por um momento" (BAUMAN, 2001, p.8). crita por Lipovetsky à visão crítica de Hal Foster em Design and crime (2013), no qual este censura a apologia à forma e à imagem do design dos produtos, nos tempos atuais, como mecanismos de individuação e exclusividade. Foster condena a excessiva preocupação formal com o design, a forma exterior, que nem sempre representa uma boa eficiência/inteligibilidade de uso (seja em um telefone celular, um tênis ou uma obra de arquitetura escultórica). Faz uma crítica contundente à "brandificação" da vida cotidiana, onde tudo parece ser desenhado a partir de uma estratégia estética.

Essa nova arte, empoderada pelos repertórios culturais, sociais e de consumo hoje é produzida e consumida por qualquer um: “Essa arte da hipermodernidade é essencialmente híbrida e não pode ser separada do perfil da nova cultura consumatória, centrada nas expectativas de qualidade de vida, de sedução, de emoções, de experiências e sensações renovadas." (LIPOVETSKY e SERROY 2015, p.92).

A partir desse ponto de vista, mais relacionado ao mercado e a um contexto antes cultural do que sociopolítico, a arte tornou-se talvez o caminho para a criação e afirmação de identidades. Há uma dessacralização da criação artística que possibilita ao homem comum produzir, mediar e veicular sua "arte" de forma independente e instantânea, livre de qualquer curadoria e institucionalização. Trataremos mais adiante da dissolução institucional da arte na era das redes em outra chave, a da produção de artemídia.

Inserido nesse contexto multicultural e desterritorializado, o cidadão globalizado está conectado 24 horas por dia a um dispositivo móvel, o gadget mais vendido e explorado pela indústria das telecomunicações e de tecnologia em todo o mundo. São mais de 7 bilhões de celulares em todo o mundo² (correspondendo

${ }^{2}$ Cf. União Internacional de Telecomunicações (UIT), dado de 27/5/2015 em <http://www.ebc.com.br/ tecnologia/2015/ 
a quase $100 \%$ da população mundial). O Brasil figura em quarto lugar na lista de países com celulares em uso, depois da China, Índia e EUA: são 255,2 milhões de aparelhos no país ${ }^{3}$, o equivalente à densidade de 1,2 celular por habitante.

Os modelos smartphones correspondem a $65 \%$ do total de celulares no $\mathrm{Brasil}^{4}$ (168 milhões). Esses dispositivos com câmeras e aplicativos de pré e pós-edição, vinculados às redes sociais, abrem novos paradigmas para essa cultura da precariedade e do efêmero. Nunca se fotografou tanto, e no meio dessa imageria há indícios de uma nova corrente artística, de uma produção de linguagem condicionada ao deslocamento e às publicações fragmentadas nas redes.

É justamente desse fenômeno de tradução e precariedade das imagens produzidas com dispositivos móveis pelo cidadão comum e por artistas que vamos tratar aqui. Importa-nos compreender como a cidade de São Paulo é representada pelas narrativas do cotidiano e pelas narrativas de artistas, amadores ou não.

\section{Narrativa radicante}

Ser radicante: pôr em cena, pôr em andamento as próprias raízes, em contextos e formatos heterogêneos, negar-Ihes a virtude de definir por completo a nossa identidade; traduzir as ideias, transcodificar as imagens, transplantar os comportamentos, trocar mais do que impor. (BOURRIAUD, 2011, p.11)

O conceito do radicante nos ajuda a entender essa produção imagética como manifestação de linguagem poética, bem como a estabelecer uma relação entre

${ }_{3}^{3}$ Dados da Anatel publicados em maio de 2016 em 〈http://www.teleco.com.br/ncel.asp〉.

${ }^{4} 27$ a Pesquisa Anual de Administração e Uso de Tecnologia da Informação nas Empresas, realizada pela FGV-SP e divulgada em 14/4/2016 em 〈http://www1.folha.uol.com.br/mercado/2016/04/ 1761310-numero-de-smartphones-em-uso-no-brasil-chega-a-168-milhoes-diz-estudo.shtml`. produção artística, deslocamento e camadas narrativas "traduzidas" e dispostas, em tempo real, de forma fragmentada, nas redes. Ao nos determos nas imagens usadas nesta pesquisa, vemos como a imagem hoje pode representar uma comunicação narcísica, a estetização do cotidiano e também uma manifestação poética. A memória radical cede lugar à atuação do radicante, onde há acúmulo de referências, multiplicidades, apropriações, sem hierarquização dos elementos formais.

Nesse ponto, Bourriaud sai em defesa da representação artística produzida na multiplicidade, embora questione se será possível redescobrir algo de incisivo no universo precário. É uma questão também aprofundada por Lipovetsky e por Jacques Rancière. Trabalhamos com a hipótese afirmativa de que, sim, descobrimos algo novo na produção artística do universo precário.

Entramos na era de novos formatos de expressões culturais e artísticas, mediadas e veiculadas por textos e imagens. A figura do DJ, usada por Bourriaud, descreve o artista do qual estamos falando: o personagem/produtor de linguagem que se apropria da produção coletiva e a agrega à sua. Ele usa a lógica do sample, do remix, do ready-made e do deslocamento do significado. "O imaginário contemporâneo está desterritorializado, à semelhança da produção global [...]", diz (BOURRIAUD, 2011, p.176).

A referência à imagem do rizoma de Deleuze e Guattari em Mil platôs: capitalismo e esquizofrenia (1996), em oposição à verticalidade da árvore, é uma citação do autor que ilustra perfeitamente a arte radicante. Inspirada na estrutura fluida da internet nos anos 1990, aplica-se perfeitamente aos dias de hoje, em tempos de redes fluidas, não hierárquicas, de geografias celulares (como veremos adiante, com Marcus Bastos).

Bourriaud pondera, no entanto, que, ao contrário do efeito multiplicador do rizoma, o radicante assume o percurso singular do autor. Esse ponto, o do reforço 
da identidade do sujeito por meio da prática estética da produção de imagens, me parece central na discussão da pesquisa para tratarmos das narrativas. O ser radicante se instala nos lugares por onde passa, cria novas raízes com os lugares, empresta-Ihes novas características temporárias inerentes ao movimento, à passagem - ele habita como locatário dos lugares presentes, um nômade. A noção de tempo-espaço passa a reger o movimento do artista contemporâneo, que não se prende a um circuito fechado, que converte a geografia em psicogeografias.

A partir do conceito radicante de Bourriaud, podemos afirmar que o papel político da arte, nesse sistema sem local preciso e estendido no tempo e no ciberespaço, é justamente o de driblar essa homogeneização de imagens genéricas, de fluxos de repetição e distribuição de informação. $O$ artista consegue, dentro do fluxo midiático, introduzir a sua mensagem, por meio de imagens, de forma singular, poética. Uma imagem potencializada, que tem a força de interromper o fluxo fragmentado de imagens no scroll infinito das telas dos aparelhos celulares e traz à tona a estética radicante.

\section{Superprodução de imagens e estetização do cotidiano}

A superprodução de imagens não é um dado novo na história. Em $O$ destino das imagens, Rancière (2013) conta que a proliferação de imagens como narrativa cotidiana tem sua origem no século XIX, com o advento das técnicas reprodutivas, incluindo a fotografia, e a descentralização das artes e do poder, antes confinados à Igreja e aos impérios e reinados. Inicia-se um período de troca entre as imagens da arte e a comercialização de novos produtos, de reproduções de "imageria coletiva" dedicada a contar uma história de uma sociedade por meios que permitem às pessoas ver-se e rir-se de si mesmas. Surgem várias publicações populares, como o Magazin Pittoresque, em que o texto e as imagens, editadas em forma de vinhetas e historinhas, espelhavam a sociedade de uma época.
A imageria, impressa ou digital, também está vinculada ao colecionismo, um elemento intrínseco à história da arte, da ciência e da tecnologia e à história da reprodutibilidade técnica desde os Gabinetes de Curiosidades do século XVI os antecessores dos espaços expositivos institucionalizados. Importante destacar a imageria representada pelo Atlas Mnemosyne, composto por Aby Warburg entre 1924 e 1929 - referência fundamental para entendermos as narrativas visuais com imagerias contemporâneas (assunto tratado no capítulo 2, Arqueo-

\section{logia das narrativas visuais).}

Nos dias de hoje, a imageria está associada a imagens digitais que circulam nas redes. Elas são publicadas em galerias virtuais, podem estar vinculadas a coleções institucionais ou privadas, ou podem ser fruto da produção individual de um artista que se apropria da imageria como matéria-prima para sua produção artística. As "coleções" de imageria produzidas de forma individual ou coletiva e disponibilizadas especificamente no Instagram, para acesso de qualquer um serão o foco central da pesquisa e estão editadas no caderno Imageria urbana.

Vimos com Lipovestsky e Bourriaud como o contexto multicultural atual propicia a produção de diversas manifestações estéticas do artista amador, do homem contemporâneo. Aprofundaremos a questão da produção e veiculação de imageria pelo artista anônimo a partir de Rancière, para quem vivemos numa época de extrema estetização do cotidiano, onde a partilha (divisão, comparti(hamento) do sensível significa a partilha de um sentimento particular em relação ao sentimento ou acontecimento comum. É um partilhar de fragmentos de espaços e tempos, simultâneos (RANCIÈRE, 2005, p.15).

Assim como Bourriaud, Rancière afirma que é justamente no terreno estético que se trava hoje a discussão política, a generalização do espetáculo e a multiplicação dos discursos. Estamos constantemente dando visibilidade às relações sociais, culturais e políticas e, portanto, produzindo no campo da estética nossa 
manifestação discursiva. O autor propõe um novo regime estético das artes no qual "a revolução estética é antes de tudo a glória do qualquer um" (RANCIÈ$\mathrm{RE}, 2005$, p.48). Esse princípio confere visibilidade ao anônimo, que é capaz de produzir arte e também conferir beleza a outros modos de representação, destituídos de sistemas e hierarquias de gêneros de representação das artes visuais. Nesse novo regime estético o banal torna-se belo como rastro do verdadeiro. A legitimidade da narrativa passa pela ficção, pela representação do belo, para que se possa pensar a história ou o acontecimento. Assim, discutem-se os arranjos entre os signos do real e das imagens, as relações do que se vê e o que se diz, entre o que se faz e o que se pode fazer, por meio da linguagem.

Para Rancière, dar visibilidade é uma operação política. A partir desse novo regime estético ao qual as imagens mobile pertencem, podemos dizer que a grande questão passa a ser como podemos medir o nosso poder por meio da nossa visibilidade. É um problema pertinente à complexidade das operações envolvidas nas publicações de imagens e mensagens nas redes sociais. Não só pela articulação entre arte, política e estética, mas sobretudo pela heterogeneidade da qualidade do que é publicado e distribuído. Os artistas anônimos têm posse da imagem, mas esta nem sempre está conectada a uma mensagem significativa. É como se a hierarquia de representação fosse quebrada por uma superprodução de imagens mudas, sem "discurso" individual. Como se a visibilidade dessas imagens dependesse de um outro sistema de representação para torná-las visíveis.

A experiência de novas formas de representação estética de imagens digitais nas redes se dá de diferentes formas. Vemos a realidade cotidiana autenticada por imagens que seguem diversos estilos, de acordo com o repertório de cada um. São imagens produzidas e utilizadas, na maioria das vezes, como emissoras de experiências hedonistas ou de manifestações poéticas de diferentes naturezas. Veremos nos exemplos abaixo uma das várias possibilidades de edição de imagens no Instagram, nos quais a legenda, ou melhor, o tagueamento do "\#" comum, organiza um discurso de imageria coletiva.
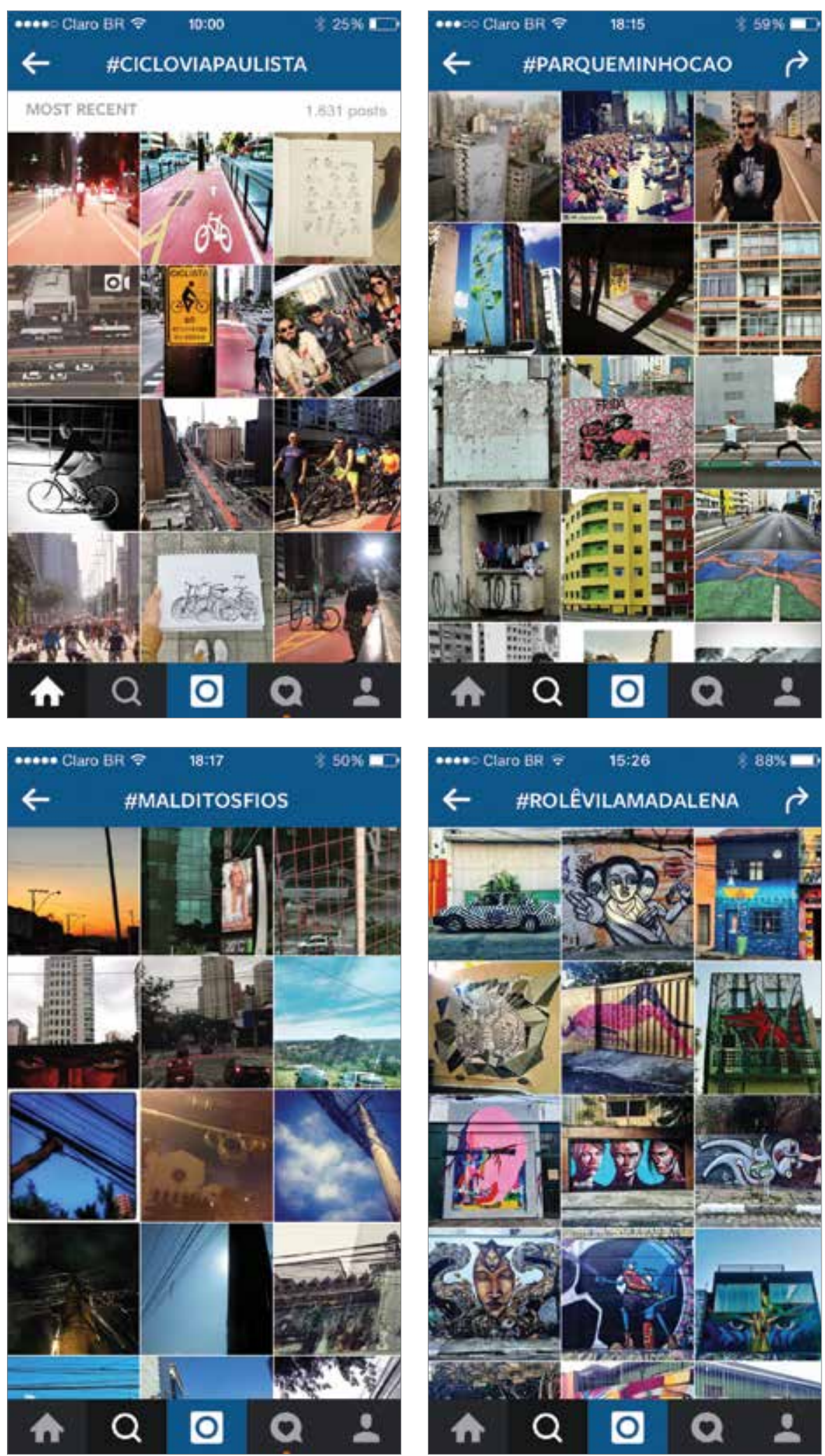

Imageria coletiva: capturas de telas a partir das hashtags \#cicloviapaulista, \#parqueminhocao, \#malditosfios e \#rolêvilamadalena (ver as edições completas no caderno 3, Imageria urbana, p. 7-45). 


\section{Imageria: novas potencialidades e funções da imagem}

Como já explicado anteriormente, adotamos a palavra "imageria" - com base em Rancière (2013) - para denominar o conjunto de novas potencialidades da imagem mobile proporcionadas pelos dispositivos móveis. Para o autor, vivemos em um momento de alteridade das imagens, em um novo regime de imagéité (traduzido na edição brasileira por imagismo):

As imagens são operações: relações entre um todo e as partes, entre uma visibilidade e uma potência de significação e de afeto que the é associada, entre as expectativas e aquilo que vem preenchê-las. (RANCIÈRE, 2013, p.11-12).

A natureza intrínseca das imagens, em qualquer meio, é a mesma. o que muda é sua performance na tela do cinema, na tela da televisão, na tela do celular. Os afetos que elas suscitam são inerentes à sua natureza e não ao meio tecnológico/performático em que são distribuídas. Para Rancière, é importante reconhecer as propriedades estéticas das imagens de arte nas transformações contemporâneas do lugar que elas ocupam. Ele está preocupado com dois tipos de jogos: o que se dá entre o real e a imagem produzida à semelhança; e aquele que consiste em operar a alteração dessa semelhança. Nesse último jogo de operações, o autor identifica que as imagens de arte, enquanto tais, são dessemelhanças e que o regime comum da imagem é aquele que põe em cena uma relação do dizível com o visível (RANCIÈRE, 2013, p.15-17).

Abrimos parênteses aqui para associar a definição do aparelho fotográfico, "brinquedo que traduz o pensamento conceitual em fotografias" (FLUSSER, 1985, p.5), com a definição feita por Rancière e relacionada à linguagem das imagens produzidas a partir da manipulação desses aparelhos. As palavras "jogo" e "brinquedo" são usadas tanto na definição da função dos novos apareIhos tecnológicos (incluo aqui a câmera celular) como na conceituação do novo regime de imagéité de Rancière. A palavra "jogar" parece-me perfeita para a discussão das narrativas imagéticas nas redes.

Rancière introduz três formas de imagéité - a imagem nua, a ostensiva e a metamórfica - e levanta três poderes vinculados à imagem: o poder de mostrar, 0 poder de significar e o poder de dar testemunho da história.

Podemos relacionar a forma metamórfica às operações de linguagens associadas às imagens produzidas com câmeras de celulares.

Segundo essa lógica, é impossível circunscrever uma esfera específica de presença que isolaria as operações e os produtos da arte das formas de circulação da imageria social e comercial, e das operações de interpretação dessa imageria. (RANCIÈRE, 2013, p.34).

Assim, o papel da imageria produzida e circulada nas redes pode ser associado ao papel da imagem metamórfica conceituado por Rancière: os novos dispositivos transferem novas funções às imagens, que passam a assumir papéis potencializados inerentes ao lugar midiático onde a imagem circula. Esses dispositivos podem transferir à imagem tarefas relacionadas à crítica e curadoria dessa própria imagem, em um jogo narrativo inédito.

Ao olhar a diversidade de fotos organizada pela busca por \#cicloviapaulista 1.631 imagens postadas em apenas 12 horas desde a inauguração da ciclovia vemos várias camadas narrativas. Esses agrupamentos de imagens fragmentadas e desconectadas, quando reunidos sob o mesmo "\#", apresentam os elementos da imagérié e do jogo de imagens e de narrativas metamórficas, descritos por Rancière. A imagem metamórfica conecta-se a outros tipos de imagens para interromper o fluxo midiático, dando visibilidade a uma narrativa. Seguindo esse raciocínio, a estética de tal imagem passa também a ter uma natureza dupla. Ela faz parte de uma narrativa singular, contextualizada por seu autor, 
participante de um jogo estetizante de produção de linguagem, e, simultaneamente, pertence à imageria de imagens produzidas como manifestações socioculturais e políticas, suscetíveis à invisibilidade por estarem no fluxo midiático. Aprofundaremos esse conceito no capítulo 4, Narrativas visuais

\#cicloviapaulista: 1.631 imagens postadas em apenas 12 horas desde a inauguração da ciclovia (ver ensaio completo no caderno 3, Imageria urbana, p. 8-15)

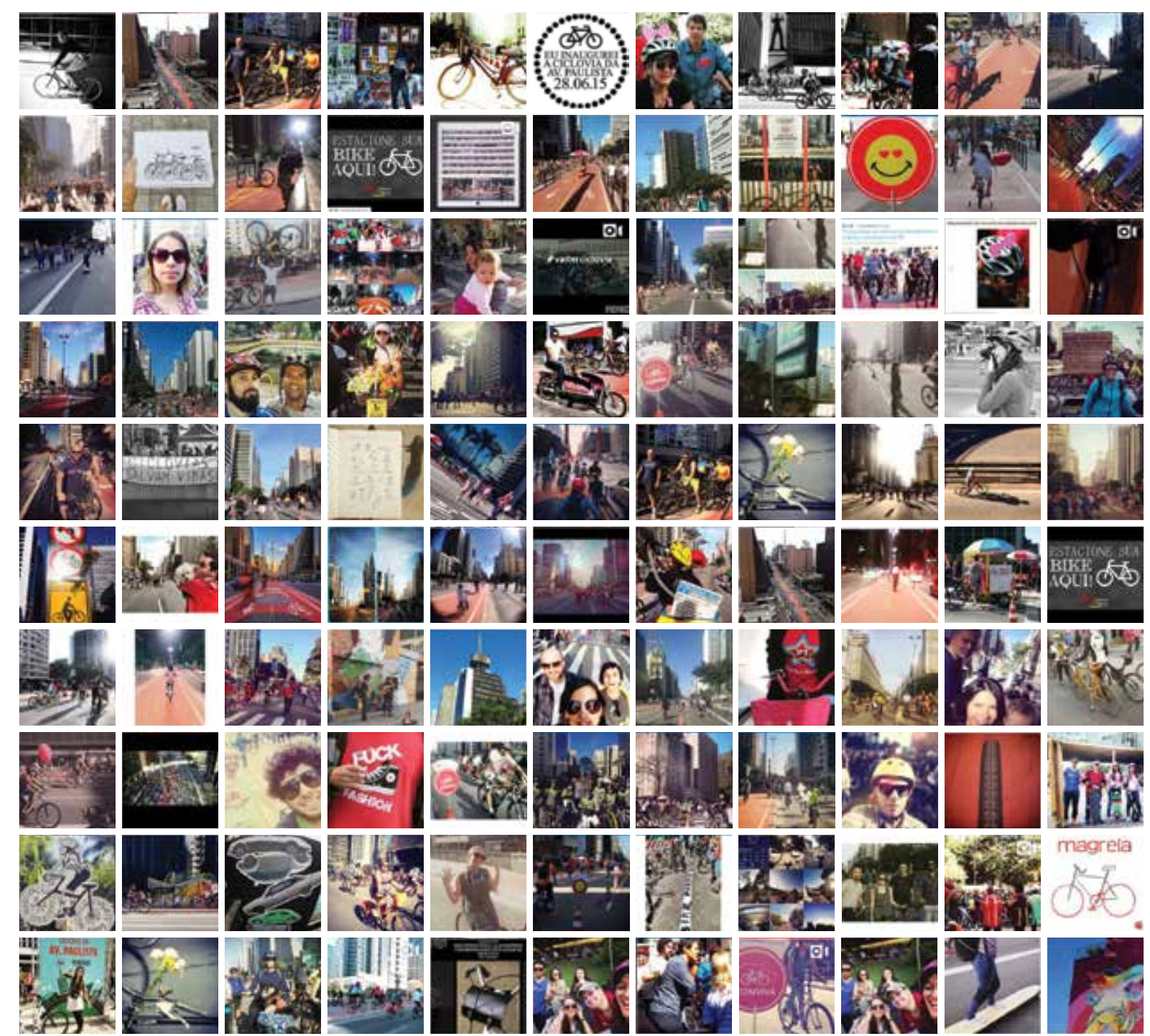

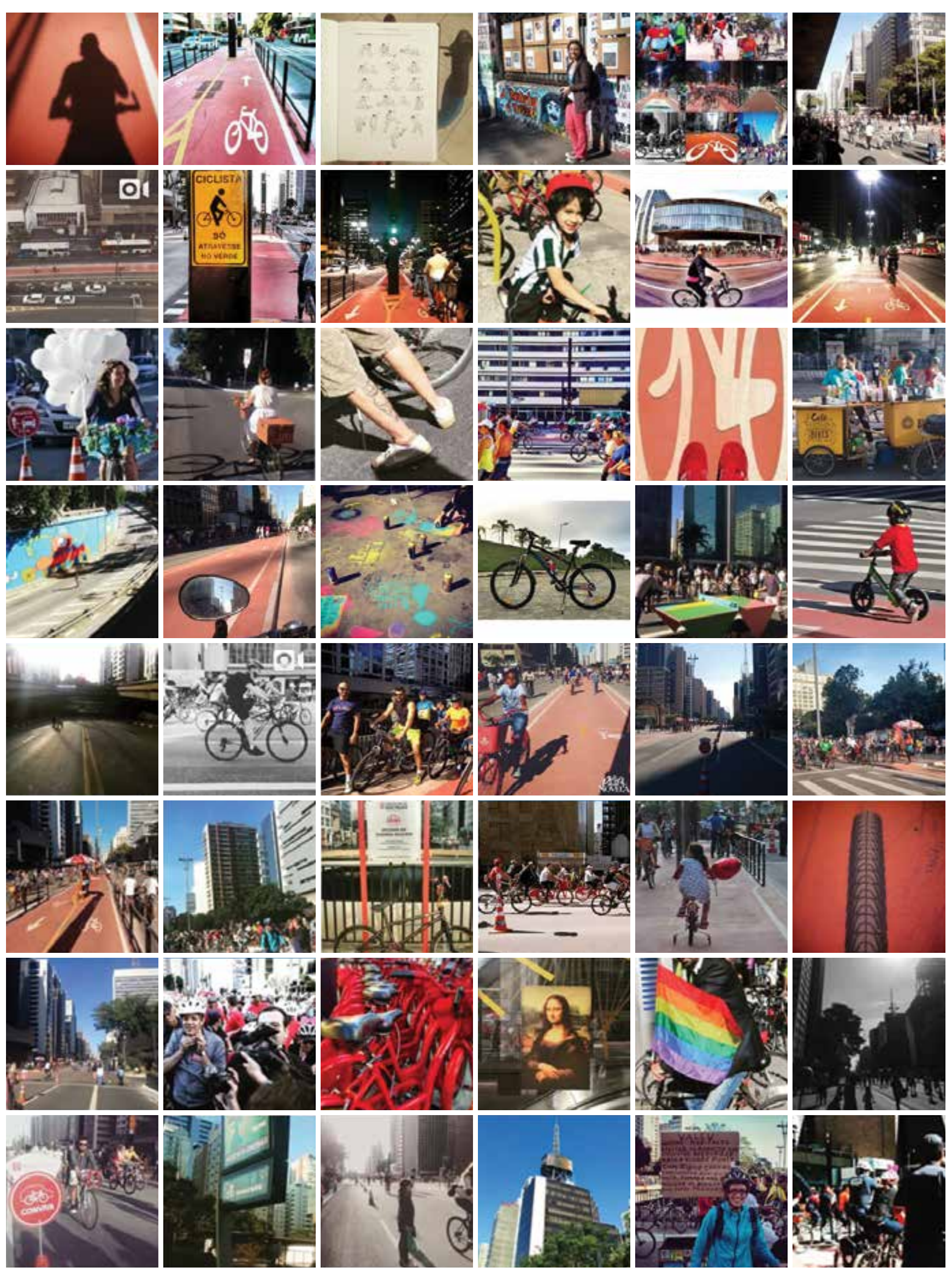




\section{Natureza tecnológica e numérica}

A partir da evolução tecnológica das câmeras fotográficas, desde as de grande formato, as portáteis profissionais, as Kodac Instamatic (ainda com filme negativo, responsável pela popularização da fotografia), as snapshots digitais (substitutas da Instamatic) e depois as câmeras dos aparelhos celulares, parece lógico associarmos a imagem produzida e projetada na telinha do celular com um tipo de fotografia digital. Veremos porém que não é bem assim.

A evolução da câmera analógica para a digital representou uma mudança de paradigma na forma de captar, ler e materializar a informação da imagem. A substituição do processo químico, que sensibiliza a prata e revela o grão da imagem analógica (da imagem fixa), pelo processo numérico, que interpreta matematicamente a luz para transformá-la em pixels, significou uma transformação radical na linguagem fotográfica e na velocidade do processo de visualização da imagem. Não representou, porém, uma mudança na origem da captação. A imagem era premeditada e sua veiculação dependia de outros dispositivos e interfaces, como o papel fotográfico, a impressão fine-art, o livro, um site.

A captação da imagem com a câmera celular funciona de forma similar à das câmeras digitais e introduz a possibilidade de veiculação automática e imediata dessa imagem, além de outras possibilidades de edição e apropriação. Essa passagem da fotografia premeditada para a imagem premediada ${ }^{5}$ tangencia outras dimensões espaciais e temporais.

" "Premediado", conceito criado por Richard Grusin no livro Premediation: Affect and Mediality in America after 9/11 (2010), em que o autor levanta o quanto as imagens do episódio de 11 de Setembro foram mediadas pelos meios de comunicação antes da publicação As ima isons de Iídia Setembro tendiam para cenas de comoção e provocavam uma identidade afetiva com o espectador: "A forma que a «imediacia» assume hoje é a de uma espécie de rede contínua. «lmediacia» deixou de ser a rasura da mediação no sentido da experiência da realidade livre de mediação, para se tornar experiência de uma ligação ou de uma rede permanente". Diana Gonçalves, "Entrevista a Richard Grusin", Comunicação \& Cultura, no 10, 2010, p.157-69. Disponível em: ‘http://repositorio.ucp.pt/bitstream/10400.14/10490/1/09.-Entrevista-a-Richard-Grusin.pdf. . Acesso em mai. 2015.
O uso dos dispositivos tecnológicos dos aplicativos possibilita várias ações, como tratar, publicar, copiar, colar, distribuir e trocar imagens, bem como apropriar-se de outras - materializadas e minimizadas numa tela pequena, em qualquer lugar e em tempo real. Essas imagens mediadas, em permanente deslocamento, são de origem (uma matriz numérica) muitas vezes desconhecida, proporcionadas pelos recursos de aplicativos de captação, edição e distribuição como o Instagram.

Em A Tecnologia na arte: da fotografia à realidade virtual (2003), Edmond Coucho trata das novas hierarquias sensoriais entre as máquinas e o sujeito. A imagem digital, numérica, é cada vez mais controlada, desde sua criação, sua morfogênese (a maneira pela qual suas formas são produzidas), até sua distribuição. As máquinas numéricas, como ele as denomina, registram outras informações além da imagem, relacionadas ao movimento do corpo, ao comando vocal, dando novas liberdades de expressão.

A imagem é uma atividade que coloca em jogo técnicas e um sujeito (operário, artesão ou artista, segundo cada cultura) operando com estas técnicas [...]. Como operador, este sujeito controla e manipula técnicas através das quais vive uma experiência íntima que transforma a percepção que tem do mundo: a experiência tecnestésica.

(COUCHOT, 2003, p.15)

A experiência tecnestésica se dá a partir de uma percepção na qual o "eu" está diluído; dá-se através do jogo perceptivo entre o eu e o fazer técnico, sobre um modo impessoal, por meio de um sujeito-NÓS. Isso não significa que o sujeito perde suas qualidades individuais e torna-se objeto, mas o sujeito do fazer técnico está fundido numa espécie de anonimato. Cria-se uma outra sincronia entre o eu sujeito e o aparelhamento tecnológico e a experiência sensível de um modo coletivo e subjetivo de se expressar. 
Para Couchot, a imagem numérica abre uma nova era da imagem. A partir da fotografia, os automatismos desencadearam cada vez mais novas associações entre a figuração, o objeto e o sujeito. Ou, como ele prefere, entre a tecnicidade figurativa e uma figura da subjetividade. A imagem numérica, ao se automatizar, ganha autonomia. Essa análise se dá a partir da evolução tecnológica da imagem e sua transmissão - a imagem fixa (fruto da ampliação com nitrato de prata), o cinema, o vídeo e a televisão, até a imagem digital do computador e celulares. Seu estudo sobre a imagem parte dos deslocamentos evolutivos do uso da imagem numérica na arte. 0 numérico traz novas ferramentas de simulação para o artista operar com programas computacionais ao invés da matéria. A imagem é tratada em outro espaço, o da ciência e dos números. A figuração é resultado de uma simulação numérica, aberta a novas potencializações.

A imagem-matriz é a denominação da imagem calculada pelo computador, que se apresenta fisicamente sobre a tela, por meio de duas dimensões de pontos, os pixels. A distribuição dos pixels é definida rigorosamente pelo cálculo numérico da máquina, e todas as características de luminosidade e cor dependem dessa varredura numérica.

Importante observar que a imagem-matriz já traz em seu nome uma característica da reprodutibilidade técnica: ela é a base para replicações infinitas, para novos cálculos computacionais. A fonte dessa imagem pode ser real (um objeto, pessoas ou uma imagem impressa que será "transformada" em uma imagem digital). Ou ainda pode ser construída e modelizada a partir de coordenadas numéricas - nesse caso, a fonte da imagem não é mais um objeto, mas um processo computacional cuja técnica permite a visualização de imagens em outros planos (visões de um espaço utópico) e obedece a outra lógica de visualização, que foge à nossa questão sobre a natureza da imagem mobile.

Couchot coloca esse diferencial da imagem-matriz e sua capacidade de novas representações como uma liberação da imagem. Esta passa a ser projetada sobre a tela, mas não é mais foto, nem cinema, nem televisão: “Com ela se instaura uma nova ordem visual em ruptura com as técnicas tradicionais da imagem, mas em continuidade com a lógica da escrita alfabética que liberava o pensamento da materialidade sonora da língua." (COUCHOT, 2003, p.164).

Essa análise sobre a imagem e as novas possibilidades estéticas oferecidas pelo numérico foi escrita pelo autor no início dos anos 2000, quando não havia celulares com câmeras. Porém, ela introduz elementos fundamentais a respeito da imagem e dos dispositivos tecnológicos sempre em evolução: conceitua a imagem em constante transformação "numérica", por meio dos aparatos e dispositivos usados pelo sujeito para produzir imagens.

A visão de Couchot, por esse prisma, nos parece muito importante pois assume o caráter de permanente deslocamento dessa imagem numérica; ela é móvel, mobile. Já não é mais uma fotografia fixada num suporte, "gráfica", e sim uma imagem cuja gênese está nas relações delicadas de um sujeito-NÓS, que tende ao tecnicismo, e do sujeito-EU, que tenta resistir a essa dependência e redefinir sua própria identidade no mundo das artes.

A imagem mobile, além de numérica, é metamórfica. Possui novos valores e novas potencialidades embutidas desde sua criação. Ela passa a ter atribuições como tagueamento georreferencial, hashtags temáticas, e acumula simultaneamente as funções de representação estética e de mídia, quando veiculada nas redes sociais.

A infinidade de formas de tratar, visualizar, deslocar, compartilhar, apropriar-se dessa imagem e vinculá-la a outras narrativas depende não mais do seu autor mas de sua potencialidade poética como imagem autônoma. Ela está condicionada às possibilidades de uso das ferramentas tecnológicas dos aplicativos na rede, que acabam por transformar essa representação do real em uma simulação de outra imagem, inerente ao ambiente midiático, imbricado no campo da ciência e da arte. 
A partir dessa abordagem de Couchot e assumindo o conceito flusseriano no qual o aparelho maquínico e seus dispositivos determinam as regras e as características da imagem, parece adequado substituirmos o termo "fotografia mobile" por "imagem mobile".

\section{Redes informacionais}

A infraestrutura para a mobilidade urbana e consequente uso dos dispositivos móveis nas estratégias artísticas e comunicacionais depende fundamentalmente da rede de telefonia celular, uma malha invisível e difusa. Esse tema é tratado por Marcus Bastos em Mapeamento incompleto de algumas geografias celulares (2010). 0 autor descreve a rede como um espaço de fluxo de dois sentidos: de deslocamento de informação e de conexões em deslocamento, configurando um regime no qual se torna imperativo pensar nos limites do visível e do invisível. Essa rede de celulares, segundo Bastos, apresenta uma estrutura multiplicadora de modelo distribuído de difusão (não há mais uma rede difusora centralizada como a TV ou o rádio).

As redes informacionais funcionam em cadeias que se reverberam, mimetizam aspectos dos organismos vivos, tecem uma malha invisível e fluida sobre a geografia física. Bastos também descreve como mimética a relação do apareIho celular com o corpo, levantando a questão da cibernetização do corpo. Do vestir-se com a rede, um grande organismo composto por conexões e espaços (BASTOS, 2010).

O uso dos dispositivos móveis está intrinsecamente relacionado ao espaço, seja no âmbito do uso do próprio dispositivo, feito pelo homem em movimento, como uma prótese de seu corpo, seja na relação com o entorno. Os trabalhos no campo da arte que se utilizam desse dispositivo, acionados pelas conexões de rede mó- veis, friccionam necessariamente esses dois espaços. 0 entrecruzamento do âmbito físico e do informático é conceituado pelo autor como "geografias celulares".

Essa definição de geografias celulares me parece muito adequada para olharmos a malha urbana tecida pelas imagens realizadas com dispositivos móveis sob outro aspecto. A partir dessas imagens da cidade, do cotidiano e da vida social, estamos acrescentando dados à história das cidades, por meio de uma camada maleável, fragmentada, subjetivada de sua imaterialidade cultural. Ou, como diz Bastos: "A cidade vê sua capa imaterial transformada em um elemento de paisagem." (BASTOS, 2010, p.10).

Um outro ponto destacado pelo autor é a aplicação do conceito de fronteira a vários aspectos da nossa vida contemporânea: as fronteiras entre o real e 0 virtual, entre o material e o imaterial etc. E há, ainda, as novas fronteiras geopolíticas, com a questão dos refugiados no mundo, nos dias de hoje. A linha de divisão é tênue e exige mudanças de paradigmas e novas reflexões sobre os limites territoriais e o entendimento de uma vida mais globalizada e informatizada.

Por esse prisma, podemos entender a maleabilidade das fronteiras das redes de uso dos dispositivos móveis. Você apreende e experiencia uma materialidade visual e discursiva, em qualquer lugar do mundo, por meio de uma imagem, um vídeo, na sua mão-celular.

O problema da fronteira também se aplica ao discurso e à experiência de acontecimentos, publicados nas redes de forma reativa, personalizada; o limite da vida pública e da privada, do autoral e do coletivo, do original e do apropriado. A partir da reflexão de Bastos sobre fronteiras e geografias celulares, problematizamos a seguir quatro questões inerentes às redes, a fim de entendermos um pouco mais sobre o lugar onde se dá a produção e veiculação dessas manifestações artísticas on-line. 
i. O uso de aparelhos celulares depende do consumo privado de aparelhos e da assinatura de planos de telefonia com tecnologia wireless. $O$ acesso é pago, embora a internet se propusesse originalmente a ser um grande espaço virtual coletivo, um ponto de encontro de livre acesso.

ii. O uso de redes sociais como YouTube, Twitter, Facebook e Instagram é gratuito e possibilitou o upload de arquivos por seus usuários. Ou seja, qualquer um media e publica sua produção (artística, musical, literária ou não) gratuitamente, sem a intermediação de instituições ou editoras (trataremos disso adiante a partir do artigo de Hito Steyerl). Já os aplicativos são extremamente controlados, funcionam com bases algorítmicas e programações e códigos fechados, mantidos por empresas privadas. Há uma promiscuidade sem precedentes no que é meu, é seu, é nosso. Não há fronteiras visíveis, a ubiquidade da rede é fato.

iii. A passagem de receptor de conteúdo e linguagem produzida e veiculada na internet, pelos downloads de arquivos gratuitos, para produtor, mediador e editor independente, livre para fazer seu upload a qualquer tempo, constitui de fato a grande mudança de paradigma para o homem cibernético atual.

iv. A mudança da cultura de rede para a cultura remix, em que a tecnologia das redes passa a disponibilizar uma infinidade de dados para serem reutilizados para os mais diversos fins, proporciona uma miríade de possibilidades de manifestações de linguagem poéticas.

\section{A tela como interface}

A tela como interface de interação com o cidadão/espectador está presente desde o cinema, no final do século XIX. Depois de quase meio século, tivemos a primeira transmissão à distância para a tela de televisão (na Alemanha em 1935 período de dominação nazista). As imensas telas urbanas integradas à arquitetura das grandes cidades surgiram em Nova York nos anos 1950, nos edifícios da Times Square, com propósitos publicitários das empresas ali localizadas (Nasdaq, rede de TV ABC, jornal The New York Times e diversos teatros e casas de entretenimento). Hoje são alugadas por grande empresas como o Google, que pagam milhões por mês por uma tela de LCD nesse lugar estratégico. Já as primeiras telas portáteis surgiram com os aparelhos de vídeo, lançados pela Sony em 1983 (em formato Betamax, hoje obsoleto).

Do tamanho máximo e da imobilidade das telas, passamos para a mobilidade do vídeo e evoluímos para os dispositivos digitais e a minimização das telas dos dispositivos móveis. Os smartphones, telefones inteligentes, na versão que conhecemos hoje, com câmeras e acesso a rede wi-fi e $3 G$ ou 4G, surgiram apenas nos anos 2000. 0 primeiro iPhone é de 2007. Antes disso, os celulares tinham função dupla de telefone e PDA (portable personnal assistant), com serviços de mensagens SMS, calculadora, alarme e outros gadgets.

Em um ensaio sobre a revolução telefônica da imagem digital e a minimização de interfaces, Wolfgang Schäffner afirma que "a chegada da imagem digita ao telefone pode ser considerada um dos acontecimentos mais importantes da história da imagem [...]" (SCHÄFFENER, 2011, p.209). Para o autor, as três principais características do telefone celular - mobilidade, minimização da tela e hibridação - criam novas relações entre comunicação e espaço.

Voltando à superfície da tela: todos os formatos apresentados, sem exceção, são interfaces de projetos culturais, educacionais, artísticos, cada vez mais publicitários. Giselle Beiguelman, em Territorialização e agenciamento das redes (em busca da Ana Karenina da era da mobilidade) (2011), aborda essa questão e levanta a importância de redimensionarmos a discussão sobre a cultura de rede e o fomento ao consumo, ao controle e ao uso crítico e criativo das mídias existentes. 
Essas microtelas são extensões de dispositivos complexos e inteligentes, dotados de conexão à internet e acesso a serviços e redes sociais. Abrem possibilidades inéditas de fomento ao consumo, ao controle e ao uso crítico e criativo das mídias e apontam para diferentes concepções e tendências políticas da ecologia midiática atual. (BEIGUELMAN, 2011, p.248)

A tela como interface de mediação com a cultura de rede na era da mobilidade e a proliferação de aparelhos e a multiplicação de pontos de acesso a redes sem fio permitem a mediação contínua do usuário e a construção de novas cartografias, novos procedimentos de territorialização e agenciamento. A autora alerta para a outra face do nomadismo e do uso de dispositivos móveis, centrais no campo da contracultura e das micropolíticas (como vimos com Bourriaud). E destaca a força do marketing, da "brandificação", que se utilizam de estratégias de "domesticação do imaginário" e estão presentes em todos os conteúdos e serviços pelos quais nos comunicamos diariamente (nos celulares, nas plataformas Twitter, Facebook, YouTube, Instagram).

Os territórios informacionais fazem parte do nosso cotidiano e estamos inseridos nesse contexto de brandificação. Torna-se fundamental, portanto, discernirmos entre as imagens publicadas a partir de estratégias de branding e as imagens nas quais nos debruçamos nesta pesquisa, cuja potencialidade poética nos conecta a outras estratégias no campo da arqueologia, da arquitetura, das artes visuais e, mais especificamente, da net art.

Beiguelman aponta para a problematização do uso controlado e privado dos territórios informacionais, mas enfatiza, com otimismo, o outro lado da moeda, das diversas estratégias que se utilizam dessa rede como lugar de produção, troca, compartilhamento e veiculação de produções artísticas. Trata da relação homem-aparelho celular a partir do pensamento flusseriano sobre fotografia:
O nomadismo contemporâneo vinculado aos dispositivos móveis pode sugerir um processo de criação dentro de cadeias industriais, em que nos tornamos amalgamados aos aparelhos e às suas regras internas, fazendo que seja decisivo o enfrentamento das normas predefinidas no seu programa. (BEIGUELMAN, 2011, p.234)

É interessante associarmos o agenciamento dos dispositivos tecnológicos ao conceito de transformatos de Bourriaud (2011). A estratégia de manipulação de dados e decodificação de informações possibilita um novo tratamento e uma nova direção formal e estética aos dados. Esta prática é usada por muitos artistas em instalações multimídia e se assemelha à estratégia do uso de \# para nomear as narrativas fragmentadas visualizadas na tela do aplicativo Instagram. Os dados algorítmicos organizam a visualização na tela do celular, configurando segmentos narrativos em quadrados sequenciais - um formato predeterminado e formalmente muito marcante, imposto pelo desenho de tela do aplicativo. Nessa interface, o transformato se apresenta como ficção narrativa e se torna o meio no qual as linhas entre arte e literatura, narrativa e forma se embaralham.

Os paradigmas teóricos de Bourriaud, Rancière, Beiguelman, Bastos e Couchot sobre o contexto e a natureza das narrativas com imagens mobile nos ofereceram uma nova perspectiva para estudarmos essas manifestações artísticas na chave da artemídia, distanciando a imagem mobile dos paradigmas da fotografia tradicional. Aprofundaremos a análise das narrativas visuais nos capítulos

\section{Arqueologia das narrativas visuais e Narrativas nas redes.}


Imageria e poéticas de representação da paisagem urbana nas redes

\section{Arqueologia das narrativas visuais: do Atlas Mnemosyne (Warburg, 1924-1929) \\ a On Broadway (Manovich, 2014)}




\section{Sumário}

VOLUME 1
Introdução

A imagem mobile:

Contexto, natureza e singularidade

1. Multiculturalismo, tecnologia e consumo

1.2. Narrativa radicante

3. Superprodução de imagens e estetização do cotidiano

Imageria: novas potencialidades e funções da imagem

1.5. Natureza tecnológica e numérica

1.6. Redes informacionais

VOLUME 2

Arqueologia das narrativas visuais:

Do Atlas Mnemosyne (Warburg, 1924-1929) a

On Broadway (Manovich, 2014)

2.1. Derivas contemporâneas: estética do deslocamento

2.2. A Instamatic de Smithson e o Instagram de "qualquer um"

2.3. Narrativas imagéticas impressas e digitais

2.4. Let's participate and play

2.5. Artemídia na história da arte

2.6. Um atlas atual e radicante

2.7. A linguagem híbrida e o espaço cíbrido

VOLUME 3

Imageria urbana: \#x

Caderno de imagens

VOLUME 4

Narrativas nas redes:

Poéticas no fluxo midiático

4.1. Imagens feitas para viajar

4.3. A habilidade do metadado de ag

4.4. \# (hashtag) $+X$ (palavra-chave)

4.5. A volta do texto. 0 paradoxo da era cibernética

4.6. Criando narrativas a partir de novos contextos e dados

4.7. A frase-imagem

4.8. Estética coletiva e diluição do autor

Referências 
Este capítulo reúne a edição de trabalhos de artistas que compõem um panorama no qual identificamos estratégias ou processos de criação, produção e veiculação similares aos tensionamentos das narrativas com imagens mobile. São narrativas visuais, compostas por imagens fragmentadas, estáticas ou em movimento, veiculadas em suportes impressos ou digitais, algumas interconectadas e apresentadas em tempo real. São exemplos de novas formas de representação estética por imagens, que lidam com mapeamento, narrativa, devir, no sentido diagramático de Foucault. Essas novas cartografias são fundamentais para entendermos as manifestações estéticas realizadas com imagem mobile nas redes, dentro de um contexto sociopolítico, pela história da arte e da artemídia.

Todo diagrama é intersocial, e em devir. Ele nunca age para representar um mundo preexistente, ele produz um novo tipo de realidade, um novo modelo de verdade. Não é sujeito da história nem a supera.

Faz a história desfazendo as realidades e as significações anteriores, formando um número equivalente de pontos de emergência ou de criatividade, de conjunções inesperadas, improváveis. Ele duplica a história com um devir [...]. (FOUCAULT, 1975 apud DELEUZE, 2005, p.46).

Investigar as narrativas visuais a partir de uma retrospectiva histórica nos ajuda a ancorar as bases das novas linguagens emergentes. A inserção da imagem mobile dentro de uma linha evolutiva da arte contemporânea pressupõe assumirmos as novas raízes socioculturais e as novas condições do meio onde produzimos e veiculamos nossas manifestações estéticas. Esse contexto foi aprofundado na chave da estética radicante (BOURRIAUD, 2011) no capítulo 1 e será retomado neste capítulo, a partir do livro Media Art Histories, editado por Oliver Grau (MIT Press, 2010), uma compilação de textos de pesquisadores sobre esse tema.

Podemos relacionar as narrativas visuais com o conceito de mapeamentos etnográficos introduzido por Jamenson em Post modernism - or the cultural logic of late capitalism (1995). Optamos, porém, por aprofundar a questão dos mape- amentos a partir de Hal Foster em "O artista etnógrafo", no livro O retorno ao real (2014), pois este aproxima esse conceito às práticas artísticas contemporâneas, associando a construção de narrativas a um deslocamento da produção artística do eixo social para o cultural - e à consequente substituição das questões sociais por problemáticas antropológicas. Para Foster, essa virada antropológica - a partir dos anos 70 com os artistas minimalistas -, na qual a arte passa para o campo expandido do espaço, traz novos lugares para a arte ao abrir uma miríade de possibilidades de expressões imbricadas em diversas disciplinas, incluindo a etnografia. 0 artista passa a realizar um trabalho de campo. Ele é um observador participante e mistura teoria à sua prática.

Os site-specific passam a ser uma estratégia recorrente das novas práticas de mapeamentos sociológicos. E Foster aponta para a fragilidade desses mapeamentos nos quais os artistas podem confundir identidade com identificação. Para ele, a identificação com a comunidade retratada, no caso de um site-specific, muitas vezes é pequena ou inexistente. Há, segundo ele, o perigo da fetichização pseudoetnográfica, uma estratégia de paródia, estereotipada (FOSTER, 2014, p.182).

Esse reconhecimento do trabalho horizontal, no qual a dimensão social prevalece sobre a dimensão histórica (eixo vertical) trazida por Foster, me parece fundamental para incluirmos o mapeamento etnográfico como uma estratégia metodológica da arte contemporânea, pertinente à virada da arte e da cultura neste século. E nos ajuda a entender as diferentes matrizes das narrativas aqui reunidas.

Já a contextualização das narrativas em rede, na chave da artemídia, foi pesquisada a partir das perspectivas de Mary Flanagan e Christiane Paul em Context Providers: Conditions of Meaning in Media Arts (2011).

É importante destacar que o critério utilizado para a seleção de trabalhos reunidos neste capítulo não segue uma cronologia ou genealogia e pode ser considerado arbitrário, na medida em que se trata de uma curadoria de trabalhos feita a 
partir de um recorte específico, que obedece a um critério de investigação específico sobre as narrativas visuais na arte e pretende responder a algumas questões relacionadas à natureza das narrativas com imagens mobile. Os artistas reunidos nessa arqueologia apresentam estratégias diferentes entre si e diferentes resultados formais, muito embora formem um conjunto riquíssimo de referências de mapeamentos imagéticos (fotográficos na maioria das vezes) sobre a paisagem urbana. A documentação do deslocamento do artista, pelo território geográfico (derivas urbanas) ou informacional (no caso de mapeamentos imagéticos no Google, Flicker ou Facebook e Instagram), é o grande elo de ligação dos trabalhos.

Por fim, incluímos o Atlas Mnemosyne de Aby Warburg (1924-1929) como uma referência histórica de construção narrativa a partir de uma imageria - fruto da prática de colecionismo. Analisamos a similaridade da estratégia de Warburg com a de artistas contemporâneos a partir de textos do próprio Warburg (1929), de Grau (2010) e de Didi-Huberman (2011). E traçamos um paralelo com os trabalhos de Lev Manovich, Dina Kelberman, Joachim Schmid, Erik Kessels e Penelope Umbrico - artistas que também lidam com colecionismo de imageria das redes e estética dos bancos de dados.

\section{Derivas contemporâneas: estética do deslocamento}

Em "Os radicantes", Bourriaud (2011) trata da busca permanente da representação do sujeito na coletividade da cidade e destaca os trabalhos atuais de Gabrie Orosco e Frans Aylis como exemplos de estratégia de deriva. Trata da errância e da mescla do real, imaginário e simbólico. Levanta a importância de esses registros artísticos trabalharem o ficcional, o regime do relato, da narrativa, que por vezes funciona como legenda, mas sem apagá-la. Assinala a atuação da Internacional Situciacionista, nos anos 60, praticada por cidadãos, artistas não profis sionais que aboliram a arte autônoma em prol de um envolvimento com as "situações vividas" por eles na cidade, independentes de qualquer campo disciplinar.

É muito comum associar as práticas de deriva de artistas contemporâneos com o flâneur moderno de Baudelaire. Entretanto, o flâneur era um burguês excêntrico, que vagava nas ruas de Paris sem um destino. As derivas propostas por artistas como Robert Smithson, Ed Ruscha, Robert Venturi, Denise Scott Brown Steven Izenour e outros apresentados neste capítulo são fruto de um planejamento e uma prática de deslocamento programada. A deriva aqui tem o significado debordiano e se aproxima da prática situacionista:

[...] O conceito de deriva está indissoluvelmente ligado ao reconhecimento de efeitos de natureza psicogeográfica e à afirmação de um comportamento lúdico-construtivo, o que, de todos os pontos de vista, o opõe às normas clássicas de viagem e passeio [...]. Na sua unidade a deriva abarca, ao mesmo tempo, esse deixar-se ir conforme as solicitações do terreno e sua contradição necessária: o domínio das variações psicogeográficas através da consciência e do cálculo das suas possibilidades. (DEBORD, 1956, apud CARERI, 2013, p.88).

Debord fazia parte do grupo multidisciplinar Situacionista que pretendia entender a cidade como um lugar capaz de surpreender. 0 trajeto é o que importa na 
deriva, o oposto da viagem (VISCONTI, 2014), daí a associação direta a cartografias e a mapas psicogeográficos. Outro aspecto relevante, inerente à prática da deriva, é o fato de ser representada por fotografias, realizadas pelo próprio artista ou por outrem, quando o artista participa da ação.

Essa escritura imagética em marcha é a crítica do urbano e funda uma estética do "deslocamento", assunto aprofundado por Francesco Careri em Walkscapes: o caminhar como prática estética (2013). 0 caminhar como ato de potência sensorial do corpo e do olho na apreensão da paisagem é tema central desse livro, no qual o autor faz um retrospecto histórico da atividade andarilha desde os povos nômades até os dias de hoje. Para Careri, o ato de caminhar já modifica o significado do espaço atravessado - o homem deixa seus rastros, os menires. Ele também explora a noção de ocupação do espaço e da experienciação estética transurbana do caminhante. O caminhar é um instrumento estético capaz de modificar os espaços urbanos, preenchidos de significados, de coisas. (CARERI, 2013, p. 28-33)

O rastreamento do espaço, marcado pelo homem primitivo com os menires, se assemelha à indexação das fotos realizadas pelo relato de viagem de Rober Smithson, assim como os pins de localização nos mapas do usuário do Instagram marcam um "estive aqui", anexado à imagem. Essa prática de mapeamentos personalizados, transmitidos por meio de iconografias específicas e fragmentadas, tem forte relação com as derivas situacionistas, surrealistas e dadaístas da segunda metade do século XX.

O vetor cartográfico da prática dessas narrativas abre outros caminhos relacionados ao tema central da pesquisa no que diz respeito ao andar como elemento condicionante da criação artística das narrativas. Por isso, vamos focar na representação poética da paisagem urbana realizada pelo andarilho.

\section{A Instamatic de Smithson e o Instagram de "qualquer um"}

Como principal referência de deriva, citamos "Um passeio pelos monumentos de Passaic", de Robert Smithson, artista célebre que utilizava sua câmera Instamatic para ressignificar objetos e lugares em narrativas singulares. Smithson lidava com os tensionamentos da desterritorialização, das alterações do ambiente natural pelo homem, e inaugurou o conceito de non-site para a sua arte, na medida em que algumas obras jamais puderam ser vistas in loco e demandavam o registro fotográfico como estratégia de linguagem.

Smithson extrapola os limites entre o real e o metafórico. O tempo, a entropia e a geologia são palavras-chaves para o entendimento de seus trabalhos. Ele trabalha com várias dicotomias: a construção modernista $X$ ruína, o humano $X$ máquina, vernacular $X$ em série/industrializado, o espaço fechado das galerias $X$ espaço aberto dos sites; o início $X$ fim, o avesso, num ciclo entrópico de de senvolvimento, construção, ressignificação, memória e esquecimento, pó

A câmera fotográfica Instamatic, lançada em 1963, marcou a passagem da fotografia profissional para a fotografia amadora, democrática. Essa câmera por tátil, de baixo custo, instrumentalizou o fotógrafo anônimo - o "qualquer um" - a produzir as imagens do instante. A Kodak vendeu 5 milhões de câmeras em apenas três anos após o lançamento. 0 uso de filmes negativos, coloridos, ASA 100 e 125, contribuiu para a popularização da fotografia. Com a câmera Instamatic de filme de 12 poses, Smithson teve de ser muito assertivo na escoIha dos elementos a serem retratados e de recorrer a uma elaboração mental e visual enorme para eleger as imagens únicas daquela narrativa fragmentada e emoldurada, típica dos filmes Kodak Verichrome. A estética das narrativas do Instagram, aplicativo usado nas câmeras celulares, disponibiliza filtros e possibilita o mesmo efeito dos filmes e técnicas de impressão usados nos anos 70 . É a possibilidade de apropriação de linguagem e da partilha do sensível do "qualquer um". (RANCIÈRE, 2005). 


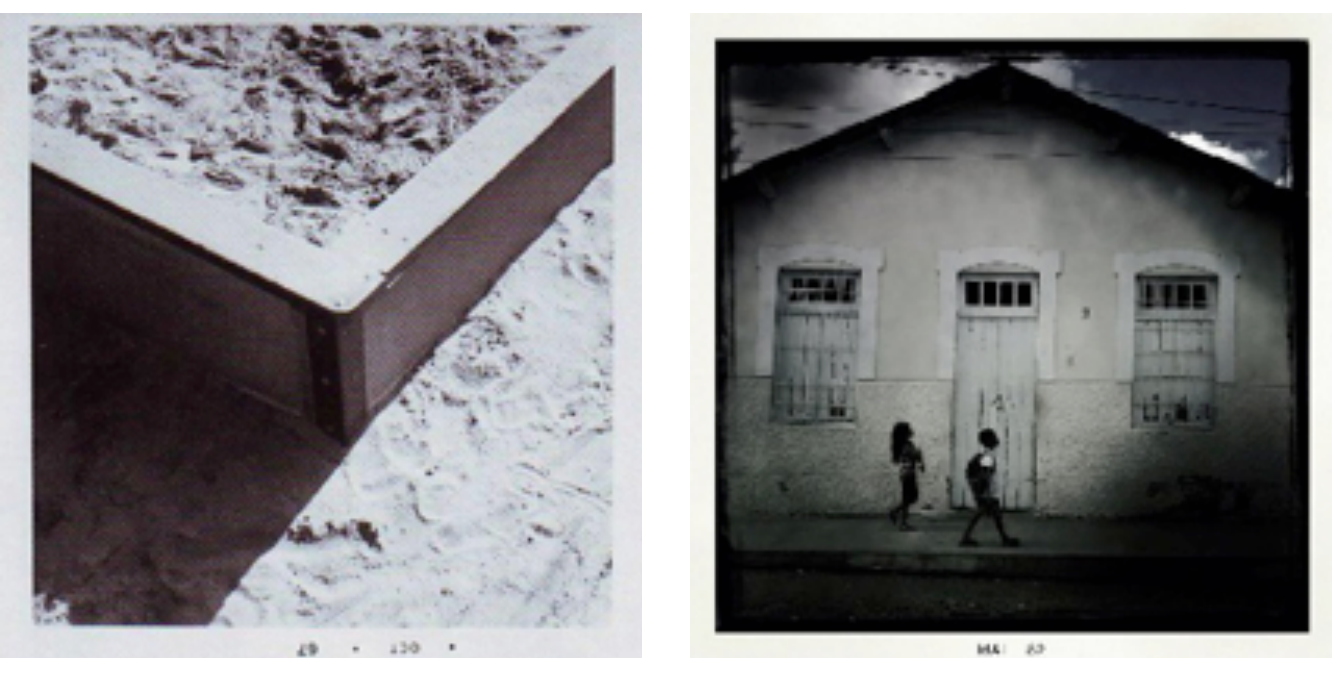

À esquerda, a última foto dos monumentos de Passaic, realizada com o filme Kodak Verichrome Pan. Ao lado, foto feita com câmera celular, com os aplicativos Hipstamatic e Instagram, que emulam os mesmos efeitos do filme Kodak,reproduzindo até a moldura com a data de ampliação à época.

Smithson descreve propositalmente sua câmera como "minha Instamatic", demonstrando afeto, como se a câmera fosse a extensão de seu próprio olho:

O sol do meio-dia dava um caráter cinematográfico ao lugar, convertendo a ponte e o rio numa imagem superexposta. Fotografar tudo isso com a minha Instamatic 400 era como fotografar uma fotografia. 0 sol converteu-se numa lâmpada monstruosa que projetava uma série sucessiva de "fotogramas" em direção aos meus olhos através da minha Instamatic. Quando andei sobre a ponte, foi como se andasse sobre uma fotografia enorme feita de madeira e aço e, debaixo, o rio existia como um enorme filme que mostrava apenas e tão-somente uma imagem branca contínua [...]. Eu estava completamente controlado pela Instamatic (ou aquilo que os teóricos chamam de câmera) [...]. (SMITHSON, 2003, p. 126).

Podemos também interpretar a expressão "minha Instamatic" pelo viés irônico de Smithson. A câmera como símbolo de pertencimento a uma sociedade de consumo. Não basta vivenciar, tem que registrar, mostrar em álbuns de viagens - o "estive aqui". Transpondo para os dias de hoje, "meu celular" é a expressão do homem contemporâneo, parte de seu corpo, extensão de seu olho, seu instrumento de comunicação via internet com o mundo, sua câmera mobile utilizada para fins recreativos, profissionais e também poéticos.

Há uma contemporaneidade metalinguística nas camadas simultâneas de narrativas e superposição de linguagem em "Passaic". Smithson também apresenta o homem-máquina e a câmera como elemento simbiótico do olho humano. Essa descrição híbrida do espaço, do estar dentro e fora, de pertencer ao mundo real e simultaneamente ao mundo metafórico das imagens, poderia ser transposta para os dias atuais para descrevermos o homem cíbrido, que vive o real e está conectado simultaneamente com o virtual, com as redes informacionais, onde ele publica e veicula suas narrativas.

A fotografia, na sua essência, também lida com a relação espaço-temporal, mas fragmenta e emoldura essa experiência, transformando-a em imagem bidimensional. 0 uso da fotografia é documental em alguns trabalhos de Smithson em que a localização é inacessível. Dessa forma, a obra passa a ter sempre um significado metalinguístico, um jogo do real e da representação fotográfica. Nesses trabalhos, nos quais a questão da entropia é latente, Smithson não se preocupa, propositalmente, com questões de composição formal da fotografia. O foco está apenas na documentação. Ao expor essas fotos em galerias, ele apresenta, na contramão da fotografia moderna americana, fragmentos de paisagens em transformação, num tempo estendido. E estabelece uma dialética entre non-site e site.

Essa relação dialética parece-nos interessante para entendermos a relação entre o real e o virtual nos dias de hoje. Como dito no capítulo anterior, as fronteiras estão borradas e de certo modo podemos habitar e nos comunicar em um ambiente "non-site", como o ciberespaço, apesar de nos referirmos, por meio 
das imagens, a sítios geográficos onde estivemos, passamos e registramos.

Em trabalhos como o relato de viagem a Passaic, a fotografia é parte inerente da obra, clicada com um propósito ensaístico. A inovação da linguagem narrativa desta texto-obra-fotográfica foi certamente influenciada pela fotografia e pela literatura produzida nesse período de novas experimentações. Na literatura, On the road, livro marco da geração beat, de Jack Kerouac, publicado em 1957, influenciou uma série de artistas. Smithson certamente se contaminou com esse mix de teorias beatnik, com William Burroughs e Kerouac, e também com a literatura realista-fantástica de Jorge Luis Borges (citada na obra Passaic).

\section{Narrativas imagéticas impressas e digitais}

A influência "on the road" de Smithson se aproxima do trabalho do californiano Ed Ruscha, que inovou e marcou a história da fotografia com a série Twentysix gasoline stations, realizada em 1963.

Ruscha faz uma road trip de Los Angeles a Oklahoma City, pela Route 66. A narrativa, editada em formato de livreto, consiste em documentar a sequência de postos de gasolina, vários deles fechados ou abandonados, na beira da estrada. Essa linguagem de deriva, de ressignificação por meio da neutralização das emoções, se relaciona à linguagem fotográfica de "Passaic".

0 artista se destacou pelas edições de fotolivros em formatos pequenos. Estava atento à linguagem e à estética da narrativa fotográfica mediada por um produto de massa, um livreto impresso reproduzido " $n$ " vezes. A sequência de fotos como um todo, aliada ao formato e ao design (as propriedades no meio de veiculação), parecia mais importante do que a fotografia em si. Ele negava veementemente ser um fotógrafo, e suas imagens, despidas da presença humana e de qualquer ação, funcionavam como matéria-prima para a obra-narrativa.
A fotografia de rua produzida até então, a street art que marcou a fotografia moderna americana do pós-guerra, com apuro técnico, iluminação e composição rigorosamente estudados, se distanciava completamente da fotografia introduzida por Ruscha em seus fotolivros. 

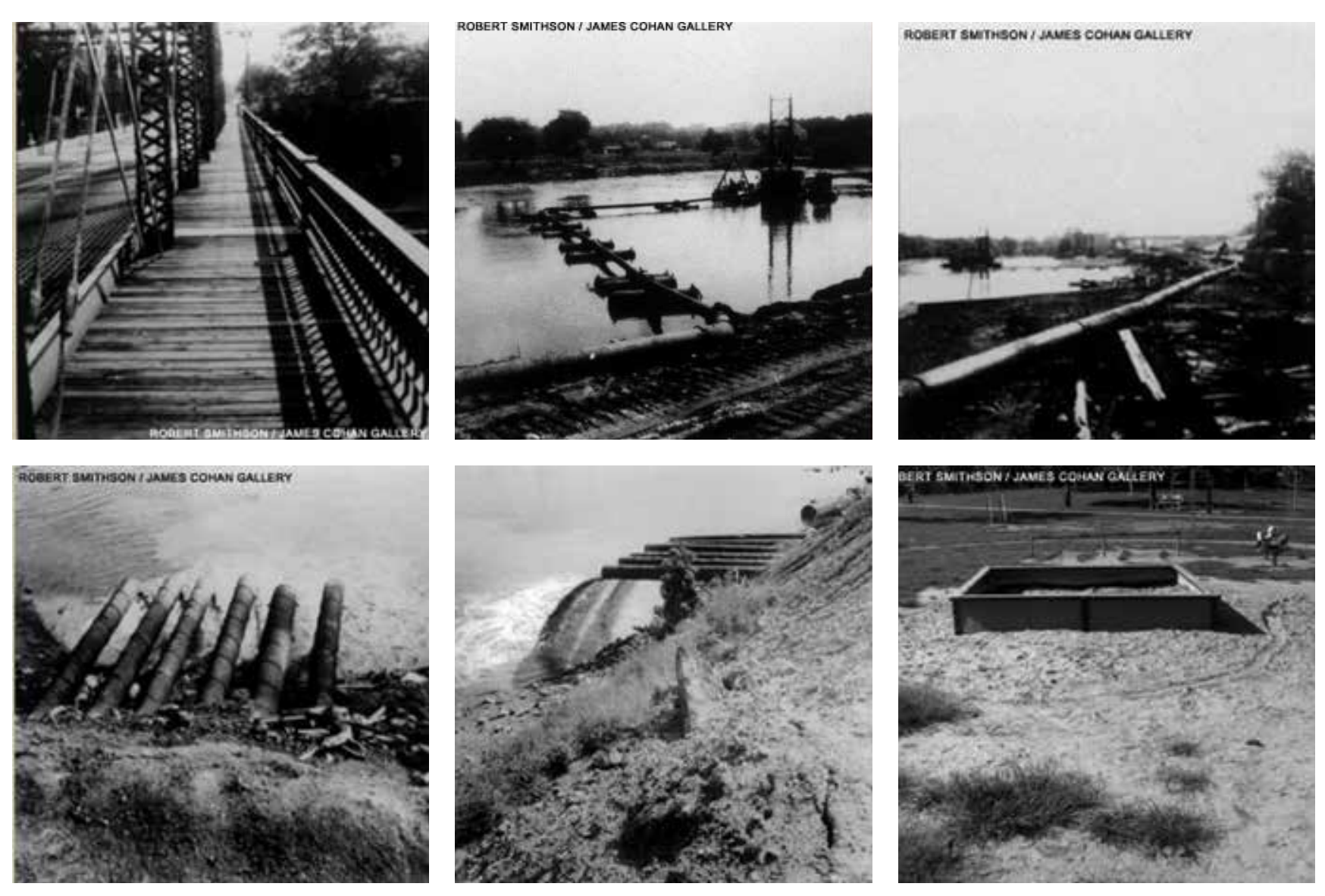
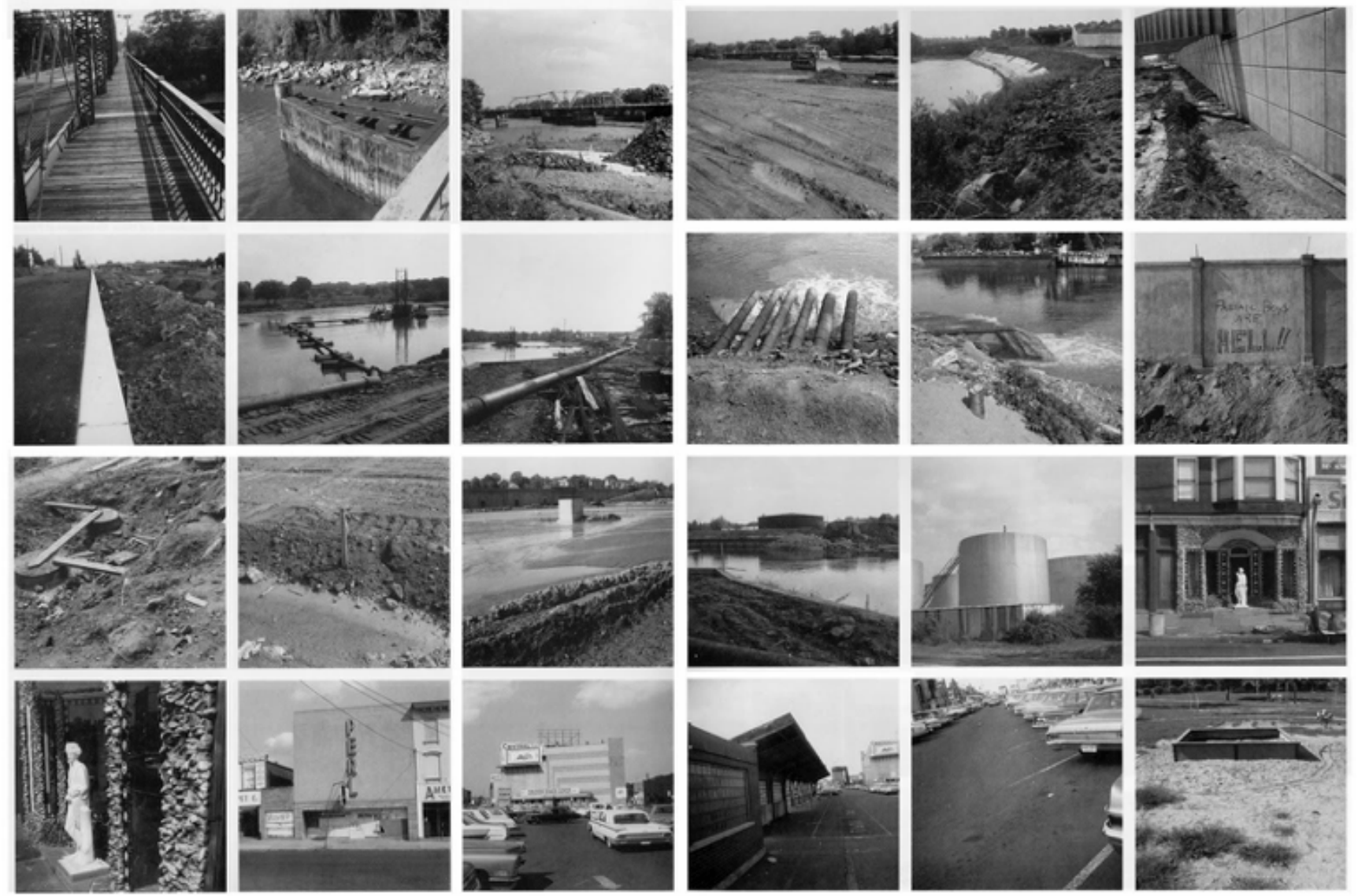

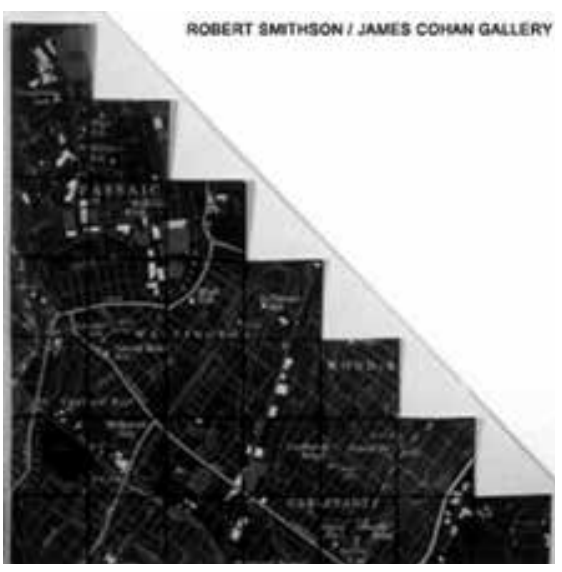

Um Passeio pelos Monumentos de Passaic (Nova Jersey, 1967. Escrito e publicado na revista Artforum Robert Smithson

Obra inédita no formato texto-obra-fotográfica, problematiza questões relativas à conceituação de espaço como lugar, a experimentações de linguagens e às fronteiras entre as artes visuais, a ciência e a tecnologia. O uso de metanarrativas é linguagem fotográfica, realizada ao longo do percurso, com a popular câmera fotográfica Instamatic, vetor da democratização da fotografia e da produção de imagem do fotógrafo anônimo. "A minha Instamatic", diz Smithson com afeto. Ou "o meu Instagram", nos dias de hoje. 
TWENTYSIX

GASOLINE

STATIONS

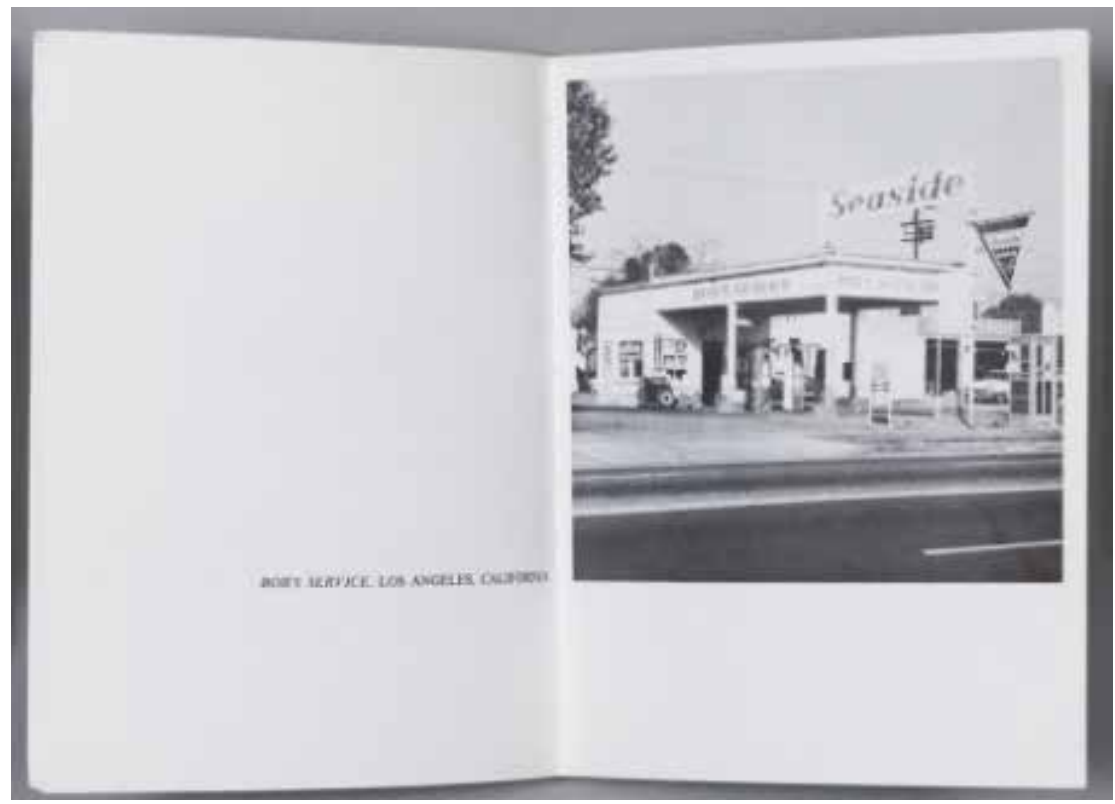

Twentysix Gasoline Stations (1963)

Ed Ruscha

Livro retrata viagem de Los Angeles a Oklahoma City, pela Route 66, por meio de uma sequência

de fotografias dos postos de gasolina ao longo da estrada. Ruscha se diferenciou pelas edicões dos fotolivros em séries temáticas e em formatos pequenos. Estava atento à linguagem e à estética da narrativa fotográfica mediada por um produto de massa, um livreto impresso reproduzido "n" vezes. Para o artista era mais importante a representação de uma ideia por meio de uma sequência de fotos, aliada ao design do produto impresso (o meio de veiculação), do que a fotografia em si. Ruscha negava veementemente ser um fotógrafo profissional.
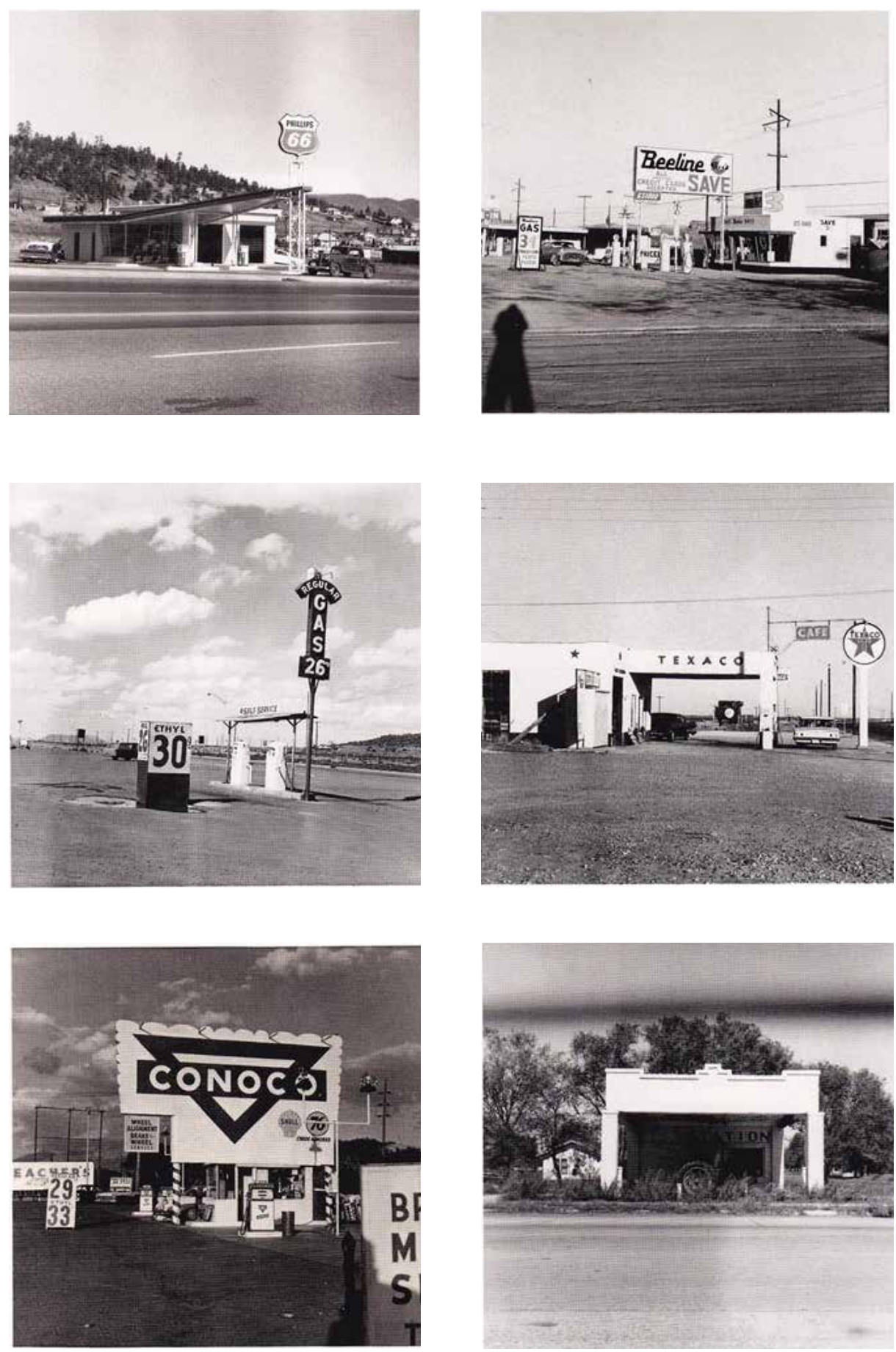


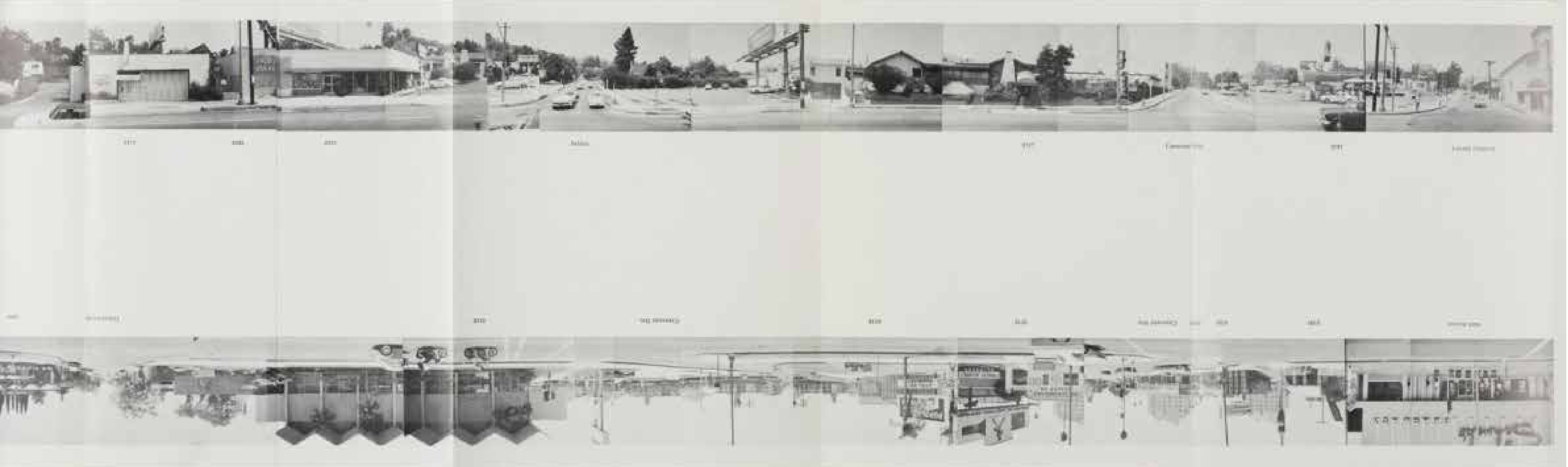

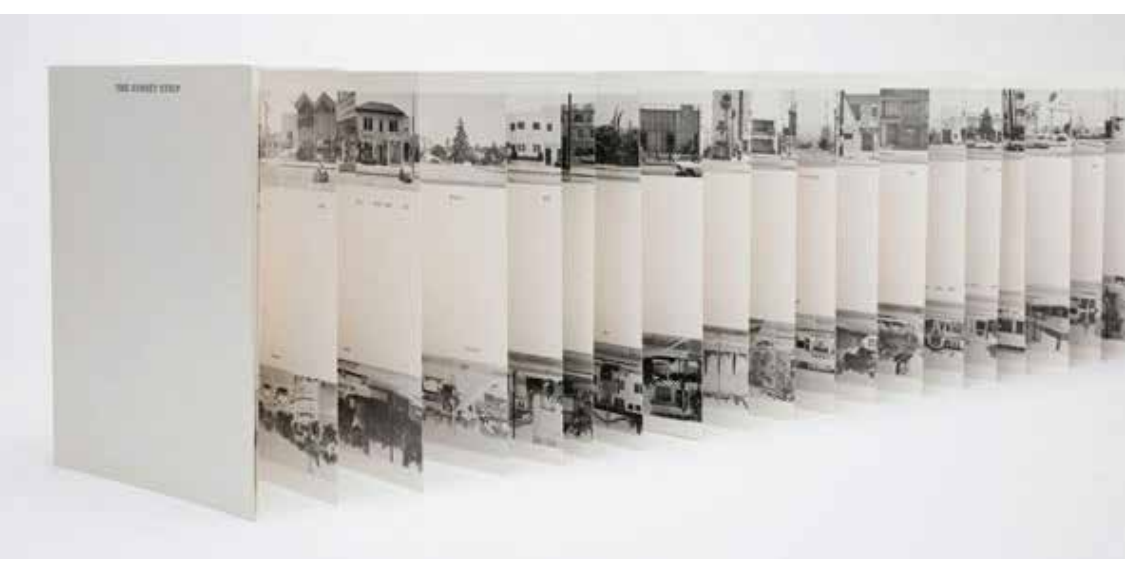

Every Building on the Sunset Strip (1966)

Ed Ruscha

Publicação própria, formato fechado $18 \times 14.4 \mathrm{~cm}$, impresso em off set. 0 autor fotografou todos os edifícios desta rua que atravessa Los Angeles, em ambas as direções, documentando a paisagem

formato sanfona. As legendas marcam os números da rua. A travessia foi feita em um caminhão com uma câmera acoplada na traseira da carroceria.

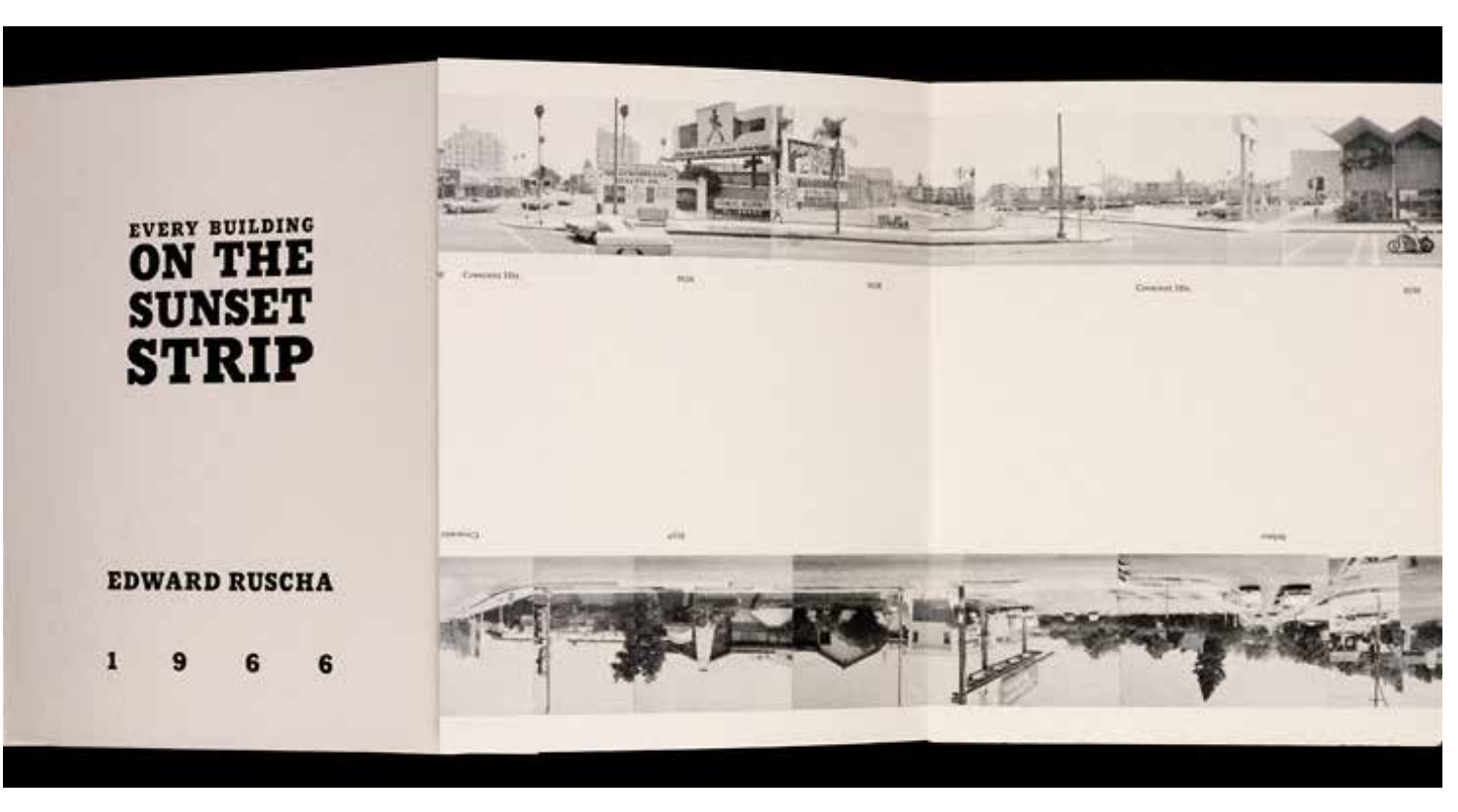


O livro Various small books, referencing various small books by Ed Ruscha (BROUWS, BURTON e ZSCHIEGNER, 2013), editado 50 anos após a primeira pubicação de Ruscha, reúne duas pontas importantes: primeiro, aponta o ineditismo da obra de Ruscha, da mudança de paradigma na fotografia, inserida no campo ampliado da arte contemporânea. Depois, analisa o impacto de Twentysix gasoline stations (1963) e de Every building on the Sunset Strip (1966) a partir de depoimentos do meio teórico-crítico e artístico, apresentando um panorama interessante sobre as questões problematizadas por Ruscha e sua influência na produção de narrativas de outros artistas em formato de fotolivros ou de livros de artistas.

No texto de apresentação do livro, o ensaísta Mark Rawlinson reúne depoimentos preciosos de críticos e fotógrafos. Vários deles, como o conhecido fotógrafo Jeff Wall, foram poucos receptivos à fotografia de Ruscha. Em Marks of Indifference (1995), Wall faz uma reflexão da passagem da fotografia moderna para a contemporânea via "arte conceitual" e enquadra o trabalho de Ruscha nesse contexto: "Conceptual art stopped short, instead shoring itself to a systematic reductivism and amateurization of the photographic medium, positing an anti-aesthetic" (apud BRouws et al, p.20). Para Philip Leider, todos ficaram irritados e aturdidos com Twentysix gasoline stations, mas se sentiram compelidos a entender o novo fenômeno que se apresentava (p.21). Para Iverson, "Ed Ruscha's books are puzzling" (p.21). Segundo o crítico Kevin Hatch, "The Ruscha's photobooks seem to exist in the gaps between media, genre, and practices; in short, they don't fit anywhere very comfortably" (p.21)

A descrição dos livros de Ruscha como "puzzling", fragmentos articulados e juntados como um quebra-cabeça, assim como a dificuldade em classificar seus fotolivros - "existem nos espaços vazios entre mídia, novos formatos e novas práticas" -, nos remetem diretamente às narrativas do Instagram. As críticas ao seu trabalho estão ligadas à natureza dessa fotografia, ao novo procedimento de produção e veiculação de imagens, e à enorme dificuldade de enquadrar a nova linguagem em alguma das categorias prescritas até então. Ele impactava a fotografia depois do surgimento da arte conceitual.

Segundo Rawlinson, o trabalho de Ruscha alinha-se com a "morte do autor" (BARTHES, 1967) e com o conceito de "ensaio" (ADORNO, 1970). Na época, apenas uma parcela de críticos e artistas percebeu o conceito dessa nova fotografia-narrativa.

Rawlinson finaliza seu ensaio de apresentação apontando a obra de Ruscha como uma mudança de paradigma do artista gênio para o artista mediador, que atua por meio de um produto de massa. Da arte contemporânea que nasce da cultura de massa, na qual a ironia, a história, a apropriação e a combinação de todos esses elementos de natureza mais urbana estão presentes. Impossível não as sociar as estratégias de Ed Ruscha com as estratégias de produção e veiculação das narrativas imagéticas fragmentadas do Instagram. Inclusive pelas críticas de muitos artistas que demoraram a perceber o potencial das ferramentas de artemídia desse aplicativo.

É dentro do contexto contemporâneo de mediação e apropriação de imagens e mapeamento que aproximamos as narrativas dos fotolivros às narrativas no Instagram como novas operações de linguagem. No primeiro, o artista mediador utiliza-se do veículo de massa impresso para veicular sua obra. Já as edições no Instagram representam a veiculação do trabalho artístico em um produto de massa digital, as redes sociais. A narrativa não é linear e só passa a ter visibilidade a partir de procedimentos específicos desse meio, como a exploração dos recursos tecnológicos do aplicativo (uso de hashtags e pins de geolocalização).

Os fragmentos de imagens dependem de uma palavra-chave para configurar uma narrativa, um conjunto de imagens colocadas lado a lado que dão sentido a uma história, a uma operação de linguagem. Passamos do folder sanfonado de 
Ruscha, ou de páginas sequenciais, para a tela com imagens decodificadas em pequenos quadradinhos, que juntos e na sequência do visor, da tela, apresentam uma narrativa fragmentada, também organizada pelo tema, ou pela sequência em que a imagem foi publicada.

Apresentamos abaixo um quadro comparativo no qual destacamos quatro aspectos relacionados às narrativas imagéticas impressas e digitais:

i. A construção da narrativa visual da paisagem urbana está relacionada ao ato de caminhar, de fotografar a paisagem, na maioria das vezes, pelo ponto de vista do pedestre.

ii. As limitações inerentes à reprodutibilidade técnica da narrativa, o limite da tiragem e, portanto, a restrição do acesso ao fotolivro em contraponto à infinitude da reprodução digital e da circulação em rede dos ensaios fotográficos on-line. iii. As diferenças entre a linearidade da leitura do livro impresso e a leitura rizomática, em camadas, e sujeita a novos desdobramentos narrativos, na rede. iv. A mudança de superfície material: a passagem do papel como suporte para a tela. Esta ainda mantém a materialidade da superfície (BASTOS, 2010). Dependemos do "quadrado branco", no caso da tela, dessa superfície que emana luz e projeta a imagem decodificada.

A representação da paisagem urbana aparece como tema central em trabalhos de vários artistas que adotam a estratégia do mapeamento e da narrativa. Os célebres Learning from Las Vegas (1972), dos arquitetos Robert Venturi, Denise Scott Brown e Steven Izenour, e On Broadway (2014), de Lev Manovich, são assumidamente inspirados por Every building on the Sunset Strip (1966), de Ruscha. O primeiro utiliza-se da fotografia como linguagem e é apresentado de forma fragmentada e linear, com imagens dos signos do consumo e da cultura vernacular californiana, reproduzidas em um livro.

O trabalho de Manovich utiliza-se do mapeamento digital realizado com dados algorítmicos. 0 resultado formal não deixa de ser uma representação fragmentada da avenida, por meio de imagens coletadas e apropriadas a partir do dado de localização geográfica do usuário do dispositivo móvel, codificado no Instagram. Um exemplo da relação entre estética do banco de dados, mapeamento e arte.

Esses artistas operam na mesma chave de Ruscha, ou seja, as possibilidades e recursos do meio fotográfico, os conceitos de composição e iluminação, são secundários. O que está em jogo é a representação da cidade, ou melhor, de determinado aspecto crítico dela, por meio da linguagem poética da narrativa. Veremos adiante, no tópico Um atlas atual e radicante, o trabalho de artistas que se utilizam de procedimentos similares para a construção de narrativas com imagens extraídas das redes. 


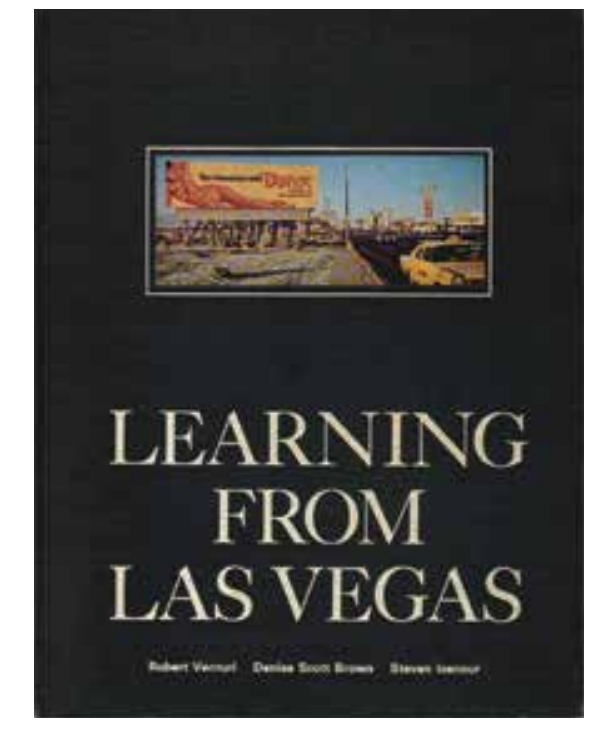

Learning from Las Vegas (1972)

Robert Venturi, Denise Scott Brown e Steven Izenour

Mapeamento iconográfico realizado pelo casal de

arquitetos recém-formados, em lua de mel, e pelo

colega Izenour. A publicação também contém mapas,

anotações e esquemas de uma nova conceituação

urbanística, representados pelo uso diversificado dos

imóveis, com suas placas luminosas (símbolo da era

do consumo e icone da arte POP), pela arquitetura

vernacular, pelo gosto popular e pelo uso de icones

como estratégia e estetica de representação da

cidade. Trabalho emblemático, considerado um marco

teórico do paradigma da arquitetura pós-moderna. Fo

inspirado no fotolivro Every Building on the Sunset

strip de Ed Ruscha. Essa apropriação confere ao
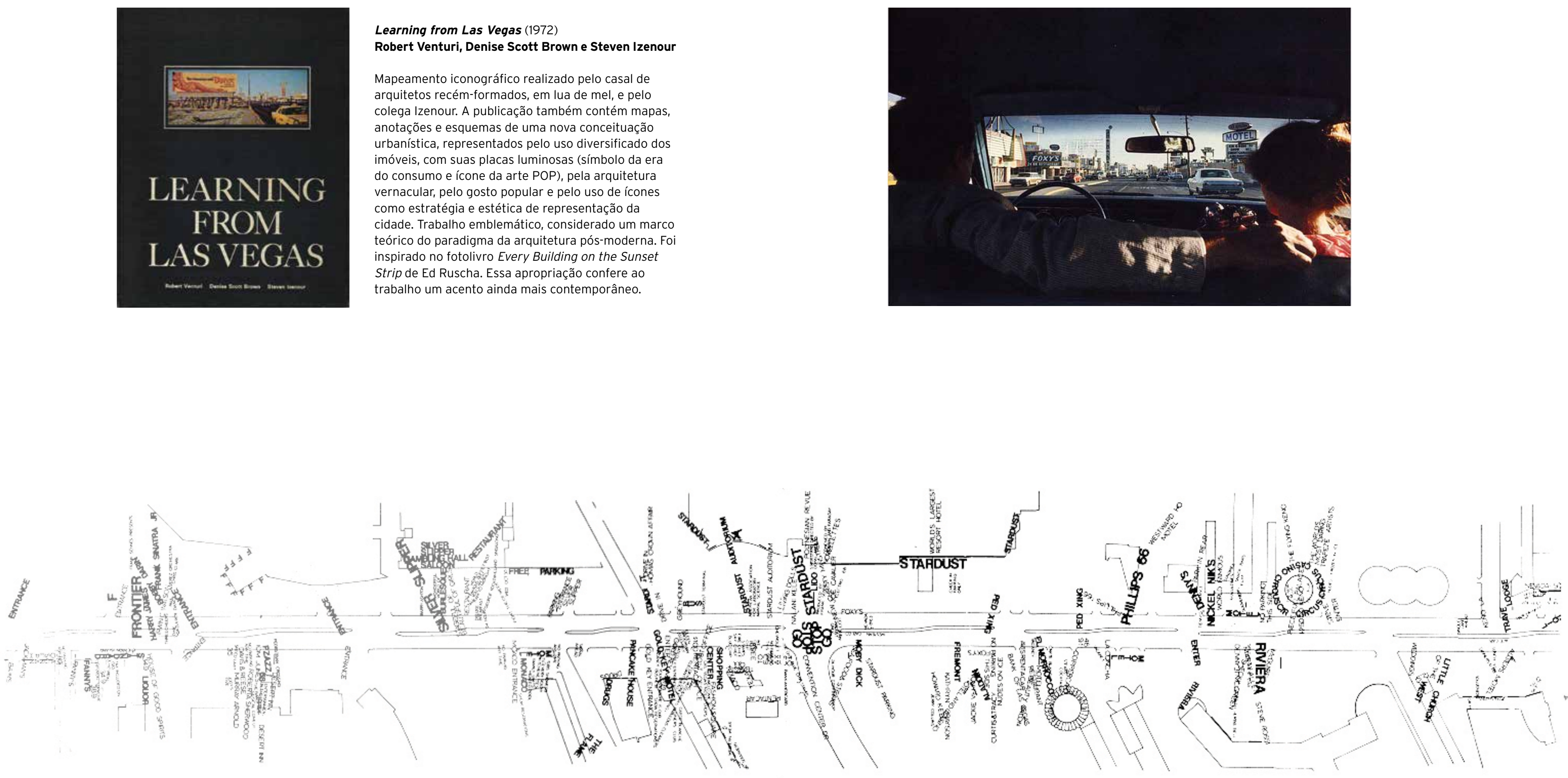

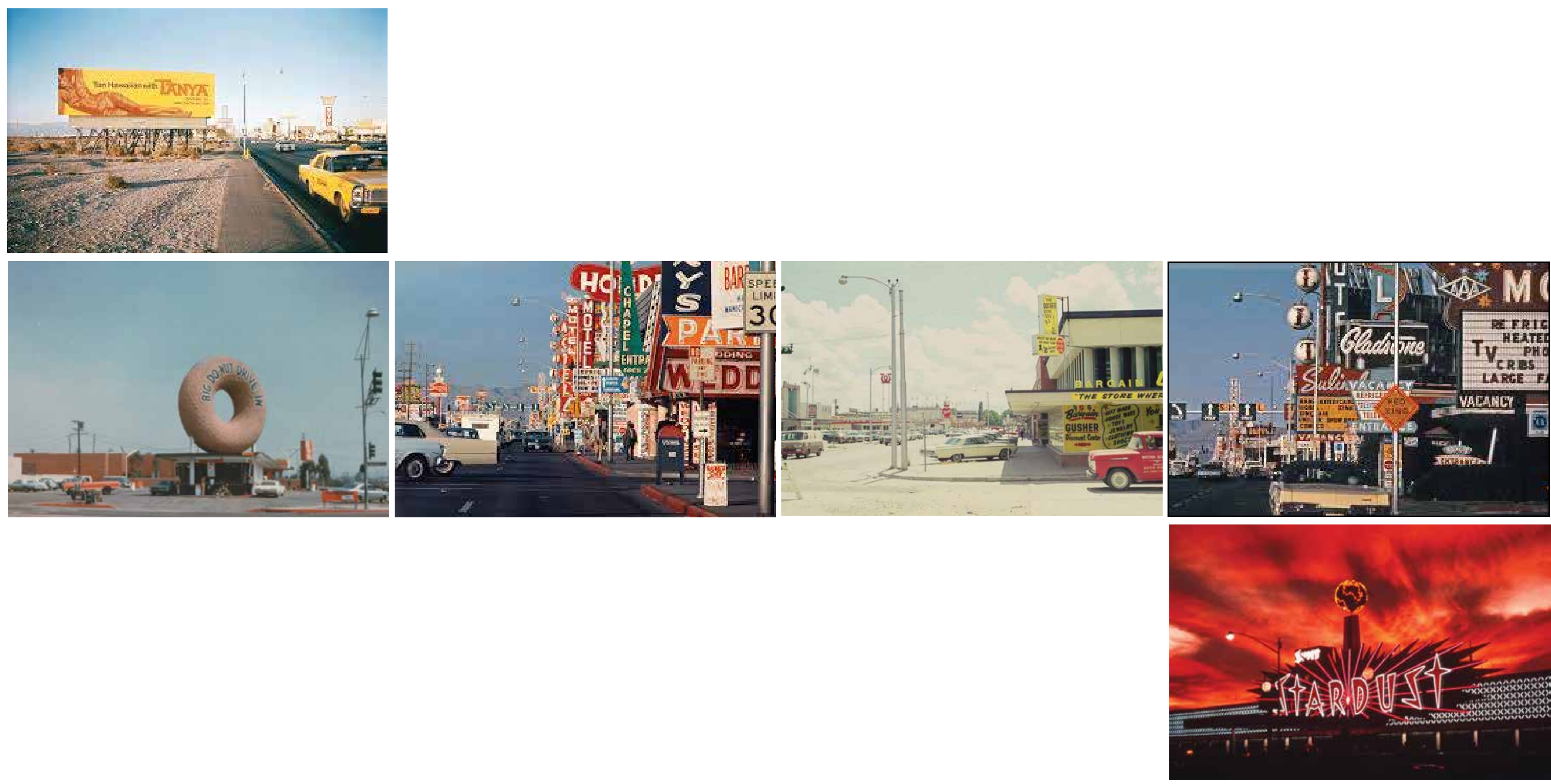

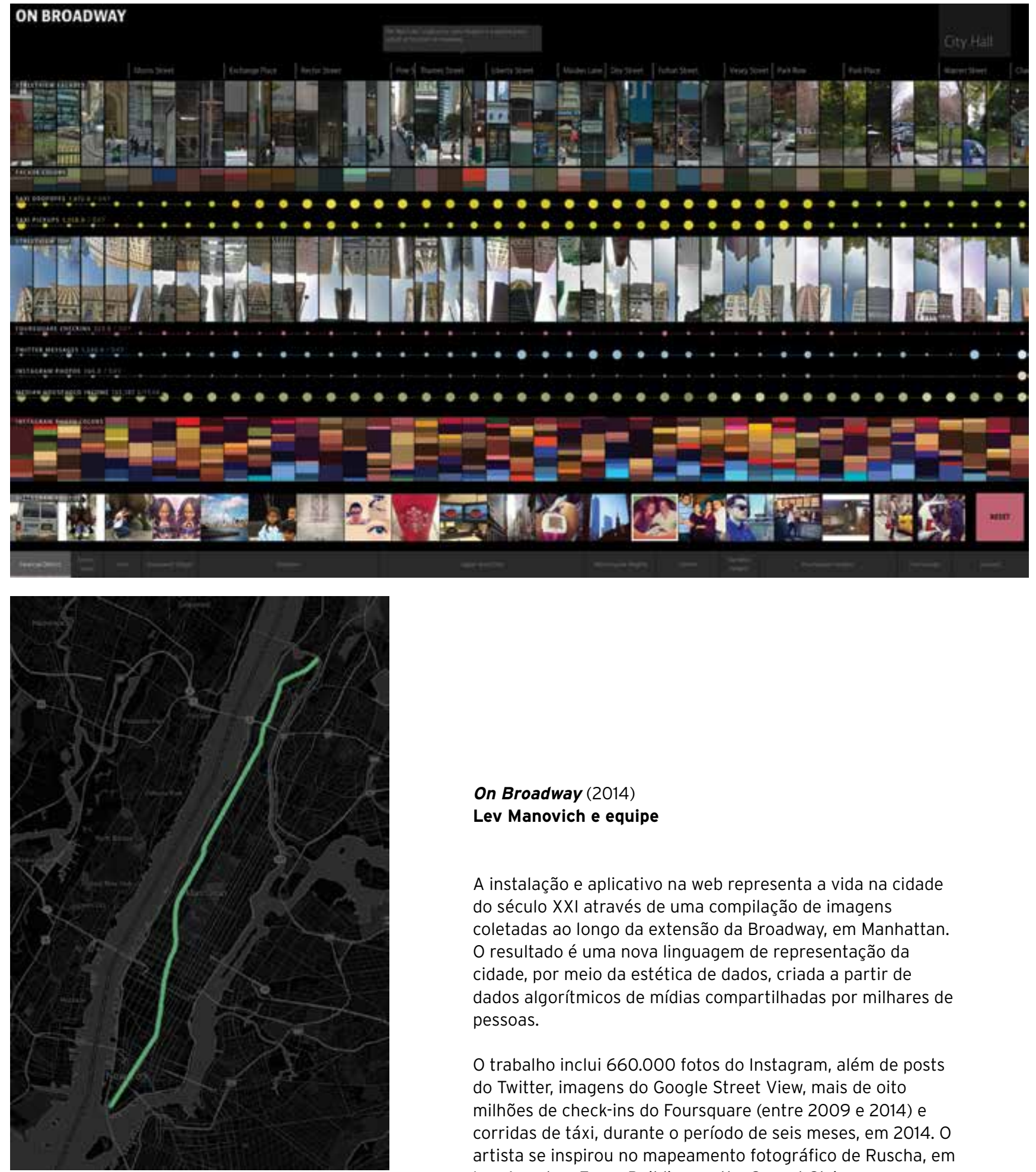

On Broadway (2014)

Lev Manovich e equipe

A instalação e aplicativo na web representa a vida na cidade do século XXI através de uma compilação de imagens coletadas ao longo da extensáo da Broadway, em Manhat $O$ resultado é uma nova linguagem de representação da dados algorítmicos de mídias compartilhadas por milhares de pessoas.

O trabalho inclui 660.000 fotos do Instagram, além de posts do Twitter imagens do Google Street View, mais de oito milhões de check-ins do Foursquare (entre 2009 e 2014) e corridas de táxi, durante o período de seis meses, em 2014 . O artista se inspirou no mapeamento fotográfico de Ruscha, em Los Angeles, Every Building on the Sunset Strip.
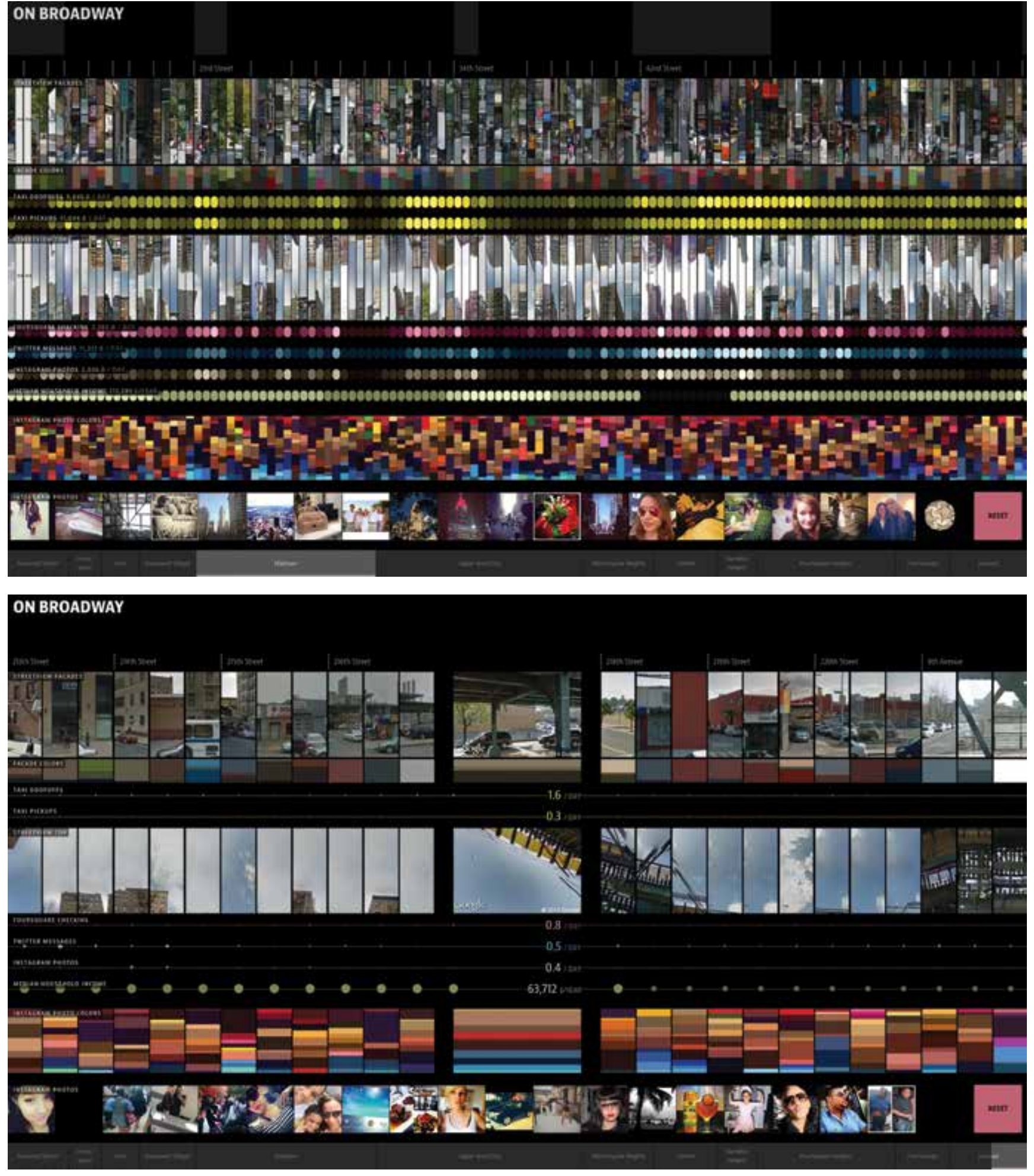


\section{Let's participate and play}

A arte conceitual dos anos 60, da qual Ruscha e Smithson se influenciaram, também é citada por Bourriaud em "Os Radicantes" (2011) e por Mary Flanagan no artigo "Play, participation and art: blurring the edges" (2011) como uma manifestação artística que antecede e pertence à mesma linhagem da arte digital. Para Flanagan, o que está em jogo na arte conceitual é a criação de metodologias e estratégias de representações artísticas individuais, dentro de identidades coletivas. Algo bastante similar ao que ocorre na web arte.

O grupo Fluxus, um coletivo do século XX formado por uma rede de artistas colaboradores de diversos países do pós-guerra, assumiu muito das características do movimento surrealista, desenvolvendo a ideia da produção artística associada à instrumentalização de estratégias sociais e políticas. Incorporavam trabalhos interativos e jogos de linguagem:

Era uma interpretação de arte fruída, com exercícios conceituais e eventos, misturando várias formas de arte e várias formas de concepção e produção artística, envolvendo impermanência, performance e objetos, publicação de periódicos manufaturados, além da distribuição de jogos com regras específicas para serem jogados por uma comunidade global [...]. Realmente a abordagem dos artistas do Fluxus parece, em retrospectiva, com os melhores trabalhos criativos na web neste novo século: impermanência, mutabilidade e integração com a experiência do dia a dia [...]. (FLANAGAN, 2011, p.91-92, tradução nossa).

A arte do Fluxus envolvia a participação do público e acontecia em lugares longe das galerias e dos espaços institucionais, criando pela primeira vez uma ambientação multiuso. Esse lugar não definido, de engajamento coletivo, é amplamente aplicado em trabalhos interativos na web, nos games e nas estratégias de uso artístico das redes.
A produção de vídeo dos anos 70-80 também merece destaque dentro dessa mesma linhagem e tem forte relação com a cultura on-line. A câmera portátil, de fácil captação e publicação imediata, trouxe a democratização da tecnologia e permitiu a produção e distribuição não institucionalizada de trabalhos que lidam com imagem e movimento e mistura de linguagens.

Segundo Flanagan, os videoartistas, guiados pela vanguarda do cinema conceitual, usavam como matéria-prima trechos de materiais veiculados na TV para fazer uma crítica ao consumo da massmedia. 0 mesmo acontece com a rede YouTube hoje, com milhões de visualizações de clips que se utilizam de spoofing (técnica que mascara a origem dos APIs por meio de endereços de remetentes falsificados), trazendo novas formas de mídia.

Flanagan faz uma comparação das bases da arte conceitual com as redes sociais: “A concepção da forma de engajar socialmente o produtor, o artista e a natureza da arte, sua fluidez e possibilidade de intervenções e de criação de eventos são antecessores das redes sociais." (FLANAGAN, 2011, p.93, tradução nossa). Destaca os eventos como fundamentais para entendermos as experiências participativas como parte constituinte da cultura de rede.

A participação do artista combinada ao uso de mídias populares (vídeo e câmeras celulares) constrói uma comunidade de artistas e de audiência em rede. A arte digital levanta questões relacionadas a origem, autoria, comunidade e imediacy (traduzido e interpretado aqui como atributo que pretende dar mais importância ou qualidade ao discurso imediato), de uma maneira única para o ambiente das redes.

Artistas que trabalham com esta ubiquidade assumem muitos papéis de interpretadores e interventores na prática de exibir seus trabalhos, às vezes em espaços tradicionais (galerias) ou "nativos", nas redes onde foram produzidos e veiculados originalmente [...]. Não são apenas 
e-mails ou imagem-arte que são uploaded e downloaded diariamente, mas, num contexto mais amplo, todo um trabalho de cultura de rede, arranjado e colocado para atingir um status de recepção como "networked art". Fazemos parte de um jogo global onde há fluidez entre trabalho, jogo, audiência e ambientes pessoais. O "blend" (fusão do trabalho e do jogo) constitui a "play culture". Todos estão engajados: trabalhadores, jogadores, familiares, amigos podem se encontrar e se reinventar. (FLANAGAN, 2011, p.93, tradução nossa).

\section{Artemídia na história da arte}

"A presença cotidiana da artemídia na nossa cultura merece ser discutida a partir de uma visão mais ampla." (GRAU, 2010, p.5, tradução nossa).

Oliver Grau ressalta a importância de contextualizarmos a produção de artemídia atual, que tem influências mútuas da arte, da ciência e da tecnologia e o status de arte digital. Devemos considerar sua abrangência e inseri-la na genealogia da história da arte das últimas décadas. Além da fotografia, do filme e do vídeo, inseridos nesse contexto entre os anos 60 e 80, a arte digital produzida hoje inclui net art, mídia interativa, genética, telemática, nanotecnologia e outros procedimentos que exigem novas reflexões e mudanças de paradigmas.

Segundo o autor, a exploração estética da interatividade das imagens e palavras cresceu exponencialmente, criando uma nova cultura de imagem virtual. Essa combinação de arte e ciência que usa um sistema tecnológico complexo de gerar novas imagens, novas interfaces, novos modelos de interação e uso de códigos, criou um universo próprio, de acordo com uma estética singular e própria, estabelecida dentro de novos domínios.

A transformação da imagem é uma nova matrix de imagens. E a mídia interativa mudou nossa percepção e conceito de imagem para uma direção mais sensorial e espacial. Podemos experimentar e "sentir" novos espaços, em outras dimensões temporais: " [...] A imagem virtual representa uma nova representação espacial e novos parâmetros temporais, de imagens transmitidas em tempo real. Temos um novo status da imagem." (GRAU, 2010, p.7, tradução nossa).

Para Grau, a história da artemídia e as origens da mídia audiovisual são tratadas, desde os anos 60, como assunto periférico da disciplina da história da arte. É importante conhecer o histórico da artemídia para compreender os valores atuais do presente e do futuro, pois tudo muda a uma velocidade cada vez maior. E, mais ainda, compreender que essa história está inserida definitivamente no mainstream da história da arte, pois cultivamos a mesma proximidade aos estudos relativos à cultura, ao cinema, às ciências da computação, à filosofia e a qualquer outra ciência que lida com imagem.

A distribuição e autoria das produções de artemídia também são tratadas por Grau. Segundo ele, as redes sociais fazem parte de um novo circuito de produção e distribuição da artemídia hoje. Como as pessoas recebem as imagens, como interagem com elas ou como se apropriam do que é produzido e veiculado não são questões meramente comunicacionais ou psicológicas. As redes sociais e os novos modelos de visualização com realidade virtual introduziram novas ferramentas relacionadas às possibilidades tecnológicas de produção e visualização de imagens. É preciso incorporar esses novos processos culturais, científicos e artísticos como um legado da história evolutiva da artemídia.

Dito isso, vamos nos deter nas transformações da imagem para compreender seu processo de hibridização atual. 0 estudo transdiciplinar de análise de imagem realizado pelo historiador de arte Aby Warburg, no início do século XX, é citado por Grau e por outros autores que estudam a imagem contemporânea, entre eles Didi-Huberman: 
No âmbito das artes visuais, o atlas de imagens, Atlas Mnemosyne, composto por Aby Warburg entre 1924 e 1929, que ficou inacabado, constitui para qualquer historiador da arte - e para qualquer artista contemporâneo - uma obra de referência e um caso absolutamente fascinante. Aby Warburg transformou o modo de compreender as imagens. Ele é para a história da arte o equivalente ao que Freud, seu contemporâneo, foi para a psicologia: incorporou questões radicalmente novas para a compreensão da arte, e em particular a de memória inconsciente. Mnemosyne foi a sua obra mestra e o seu testamento metodológico: reúne todos os objectos da sua investigação num dispositivo de "painéis móveis" constantemente montados, desmontados, remontados. (DIDI-HUBERMANN, 2011). ${ }^{4}$

A pesquisa de Warburg é referencial para entendermos a expansão e a imbricação das imagens da arte e as imagens da ciência. Sua pesquisa inclui todas as formas e mídias de imagens e a construção de uma impressionante bibliote$c a$, e nos traz uma possibilidade interpretativa de um todo universal, que pode sempre revelar importantes descobertas em imagens aparentemente marginais (GRAU, 2010).

Interessante recorrer aos painéis do Atlas Mnemosyne para estudarmos a natureza das narrativas formadas por imagens aparentemente heterogêneas. 0 que elas podem representar quando reunidas, diagramadas e apresentadas em outro contexto, lado a lado.

4 "Atlas - Como levar o mundo nas costas?" foi escrito por Didi-Huberman para a apresentação da exposição homônima no Museu Reina Sofía, em Madri, 2011. Disponível em: 〈http://www.artecapital. net/perspetiva-119-atlas-como-levar-o-mundo-\%C3\%AOs-costas--apresentacao-por-georges-didihuberman〉. Acesso em ago. 2016.
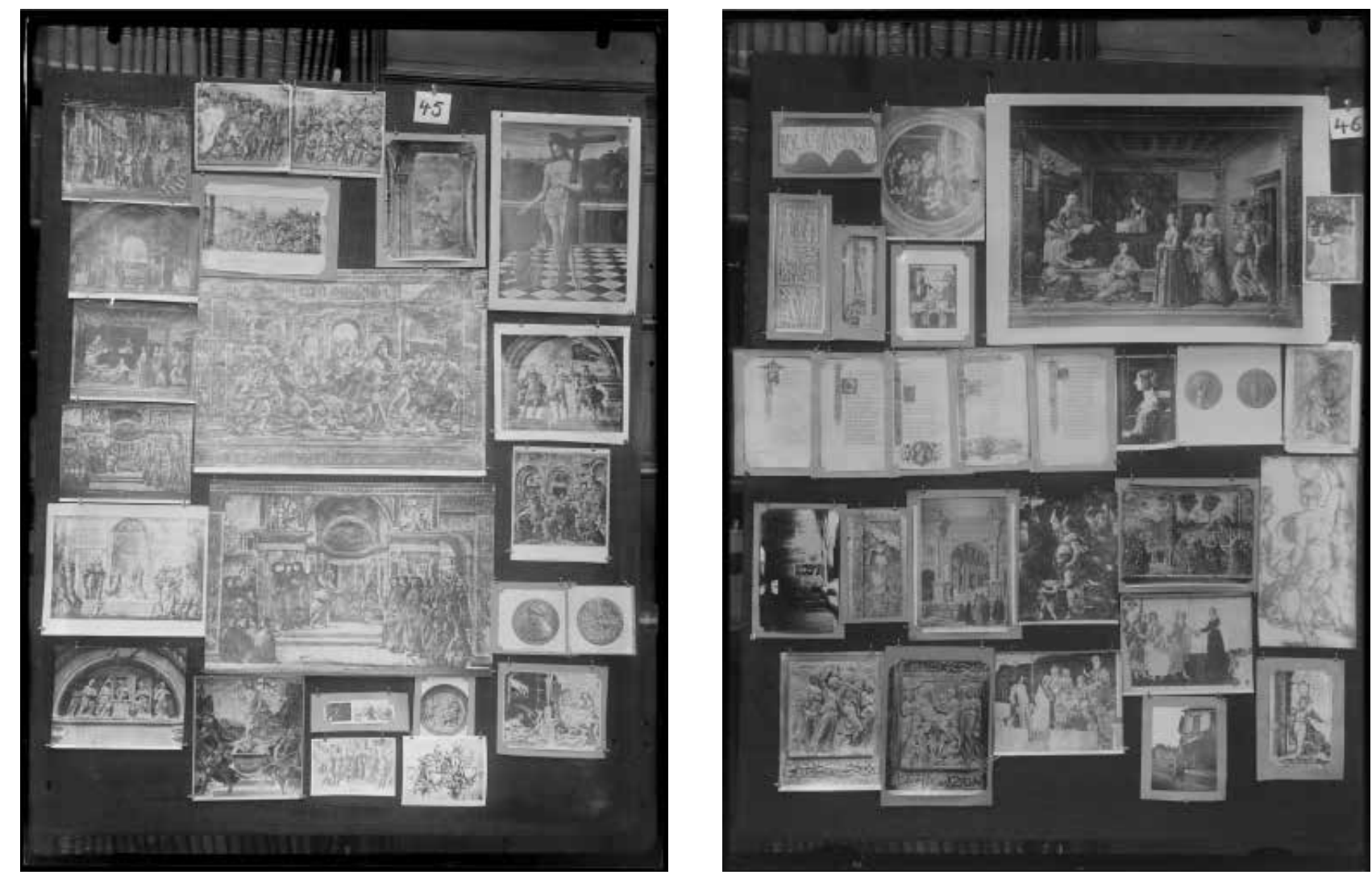

\section{Atlas Mnemosyne (1924-1929)}

\section{Aby Warburg}

Na sua "última versão", o Atlas Mnemosyne consistia em 63 painéis, medindo aproximadamente $150 \times 200 \mathrm{~cm}$, cobertos por tecido preto e moldura de madeira. Warburg fazia e desfazia arranjos da arte, além de imaginatório de adição e subtração de fotografias preto-e-branco da histór contemporâneas à época de jornais e revistas. Os painéis eram numerados no verso e ordenados de forma a criar uma extensa sequência temática.

Warburg pretendia completar pelo menos 79 painéis, mas faleceu antes, deixando o trabalho

inconcluso. O Atlas está "congelado" em um estado no qual pelo menos 971 imagens representam fragmentos da história da arte e da cosmografia, diagramadas sem qualquer identificação, lado a lado, compondo parte das "Wanderstrassen" (ruas caminhantes) de Warburg. Disponível em: <http:// warburg.library.cornell.edu/>. Acesso em mai. 2016. 

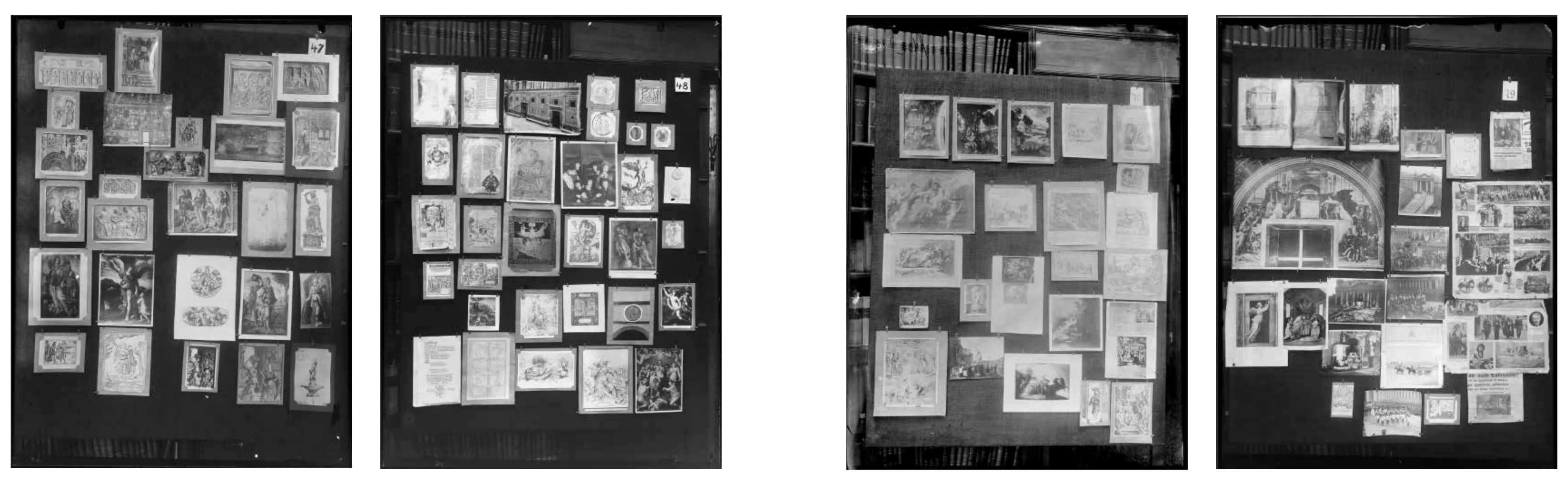


\section{Um atlas atual e radicante}

Em Histórias de fantasma para gente grande, uma compilação de escritos, esboços e conferências de Warburg (2014), encontramos um texto sobre Mnemosyne:

A Mnemosyne, com seu alicerce de imagens (caracterizadas no Atlas por meio de reproduções), a princípio pretende ser apenas um inventário das pré-formações de inspiração antiga que verificadamente influenciaram a representação da vida em movimento na época do Renascimento, contribuindo assim para a formação do estilo [...]. (A. W. 10/6/1929 in WARBURG, 2015, p.366).

Segundo Warburg, o Atlas pretendia ilustrar as experiências humanas e sua representação na arte, o páthos do homem engajado em representar diferentes concepções de mundo: a prática oriental, a do humanismo italiano, as da corte do norte. Ou, em outras palavras, ilustrar o processo de representação dos valores expressivos à época: entre o humano e o pagão, o espiritual e o divino, o orgiático e o cósmico.

Quando comenta sobre sua busca pela expressão própria na criação do Atlas, Warburg explicita a apropriação de imagens como prática criativa: "Esse estí mulo se realizou por meio de uma função mnêmica (isto é, por meio de formas pré-formadas já buriladas e abarcadas pela figuração artística), um ato situado entre a exteriorização pulsional de si mesmo e a figuração formal, consciente e domesticadora [...]. ". (WARBURG, 2013, p.369).

Os painéis representam um conjunto de narrativas, formadas por uma edição de imageria que à época questionava as influências culturais, as raízes de origem clássica e eurocentristas, e introduzia a influência de outras raízes tão pertinentes na formação de uma estética mais "universal" - se é que podemos dizer mais pertinentes às noções de estilo e representação artística para Warburg.
A livre associação das imagens nos painéis e a serialidade destes nos remete à estética radicante de Bourriaud. Ela já se apresentava, de forma inédita, nesse trabalho do início do século XX e nos ajuda a compreender a heterogeneidade da imageria das redes e toda a problematização de autoria, apropriação e ressignificação presente nas narrativas das redes.

Artistas como Dina Kelberman, Joachim Schmid, Erik Kessels, Penelope Umbrico, Michael Wolf, Antoni Abad, Lev Manovich e Giselle Beiguelman utilizam-se de procedimentos similares e adotam o colecionismo de imageria como matéria-prima para a edição narrativa de suas obras. Trabalham na chave da apropriação ressignificação de imagens que circulam nas redes e representam a cultura de massa digital. Os trabalhos são veiculados em diversos suportes, impressos e digitais, ou em instalações interativas, como Small Universe de Kessels (2014) e a exposição multimídia interativa On Broadway de Manovich (2015). Veremos também, no caderno Imageria urbana, exemplos de como imagens mobile tão díspares, de diferentes origens, também podem compor uma narrativa coletiva.

Warburg também renunciava à autoria em nome de uma coletividade introjetada em sua obra. Em termos de construção de linguagem, é notável o pioneirismo da obra na imbricação entre arte e ciência - observada por Grau -, o que nos faz lembrar da importância de nos atermos à história para compreender as transformações das imagens. 

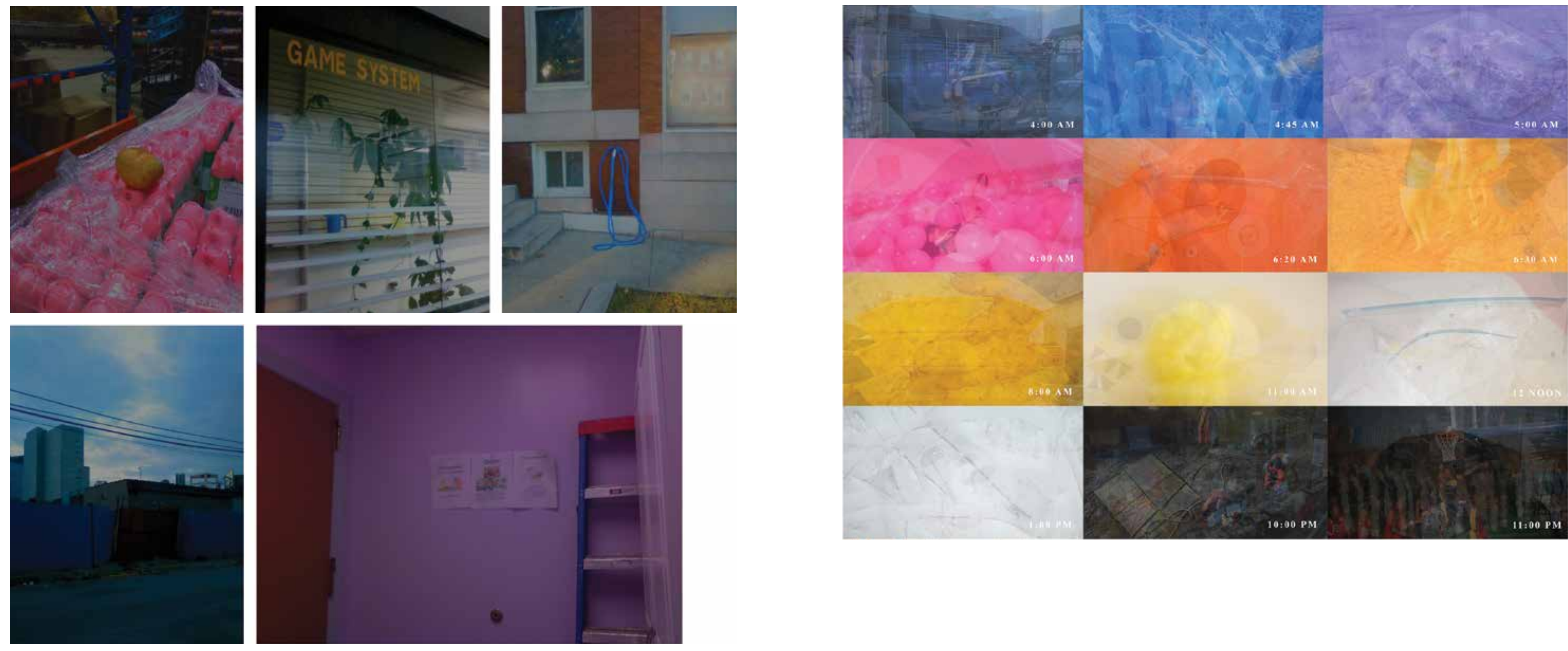

Go Outside (2015)

Dina Kelberman

Trabalho interativo hospedado no website dinakelberman.com/gooutside. 0 aplicativo captura

imagens aleatórias veiculadas na rede (Google, Flickr) no momento em que o usuário está online. A

artista se apropria dessas imagens, criando uma narrativa em sequência cronológica e cromática:

a localização geográfica do usuário. 

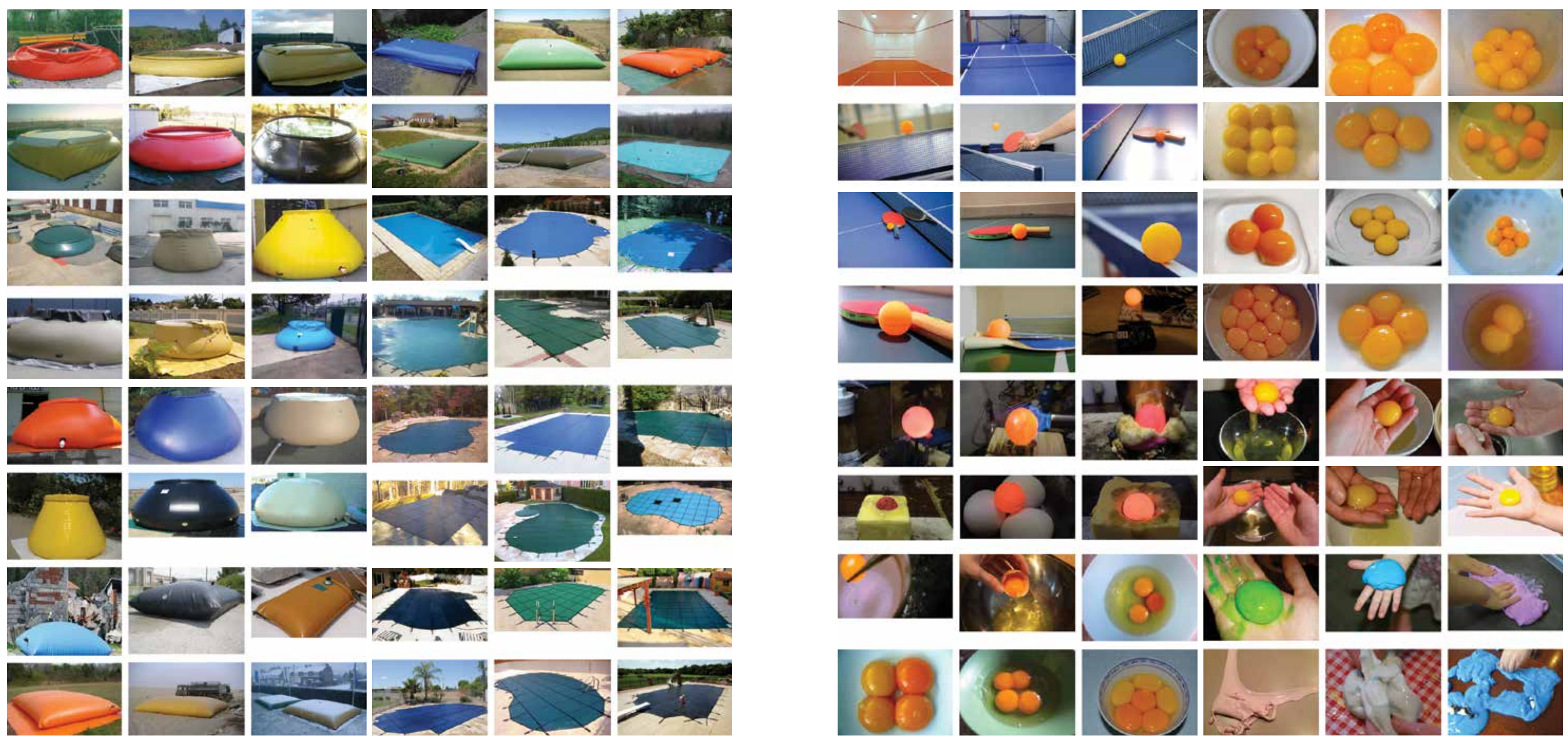

I am Google (2011 - em andamento)

Dina Kelberman

Imageria editada a partir do Tumblr de Kelberman. A artista relaciona o imaginário coletivo, representado pelos mesmos objetos, com associações formais e funcionais para criar uma narrativa contínua com imageria própria. 

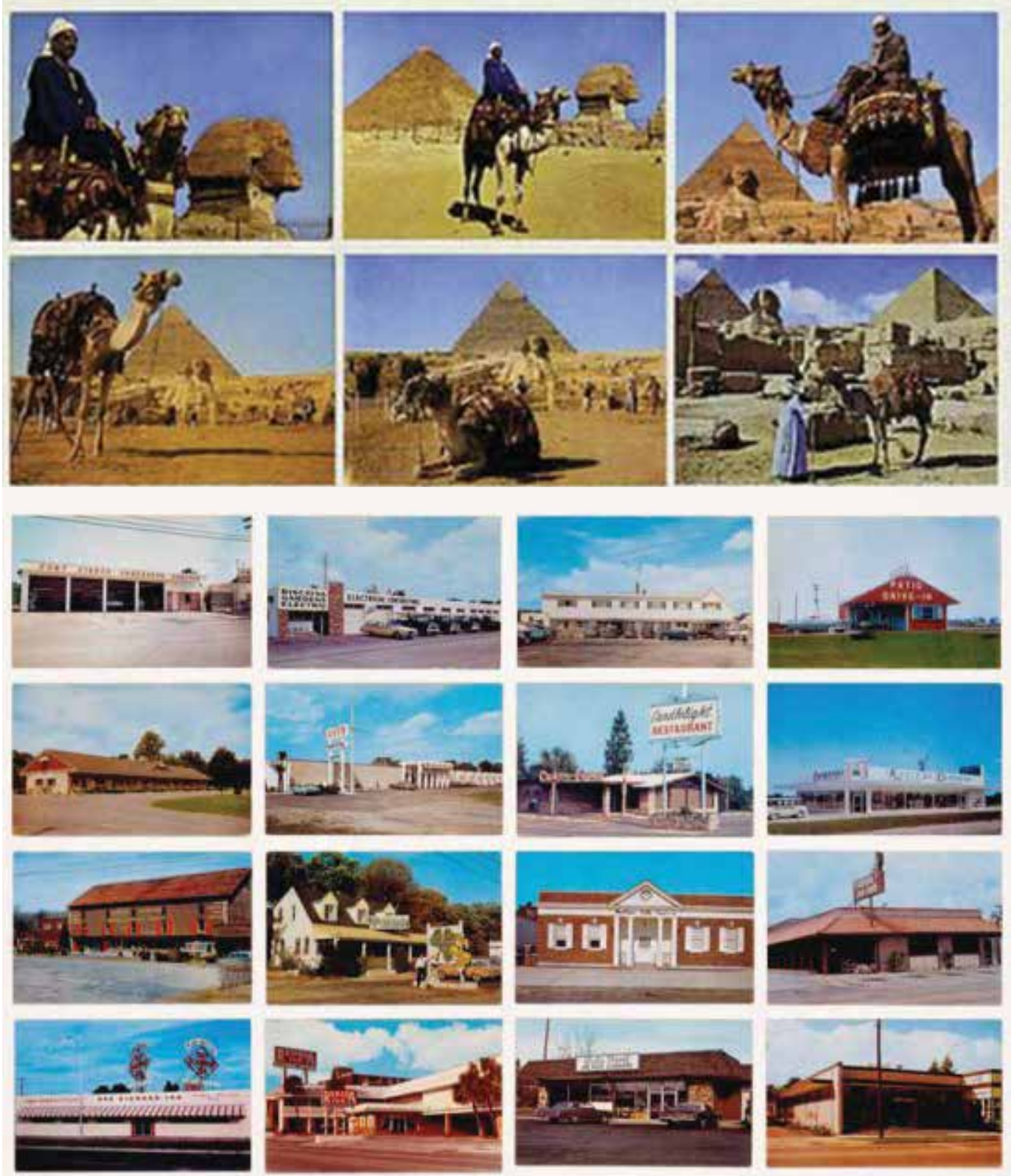

Other People's Photographs (2008-2011) Joachim Schmid

Série de 96 livros explora os temas e padrões visuais do dia a dia de fotógrafos amadores. Imagens encontradas em sites de compartilhamento de fotos como o Flickr foram reunidas em um acervo,
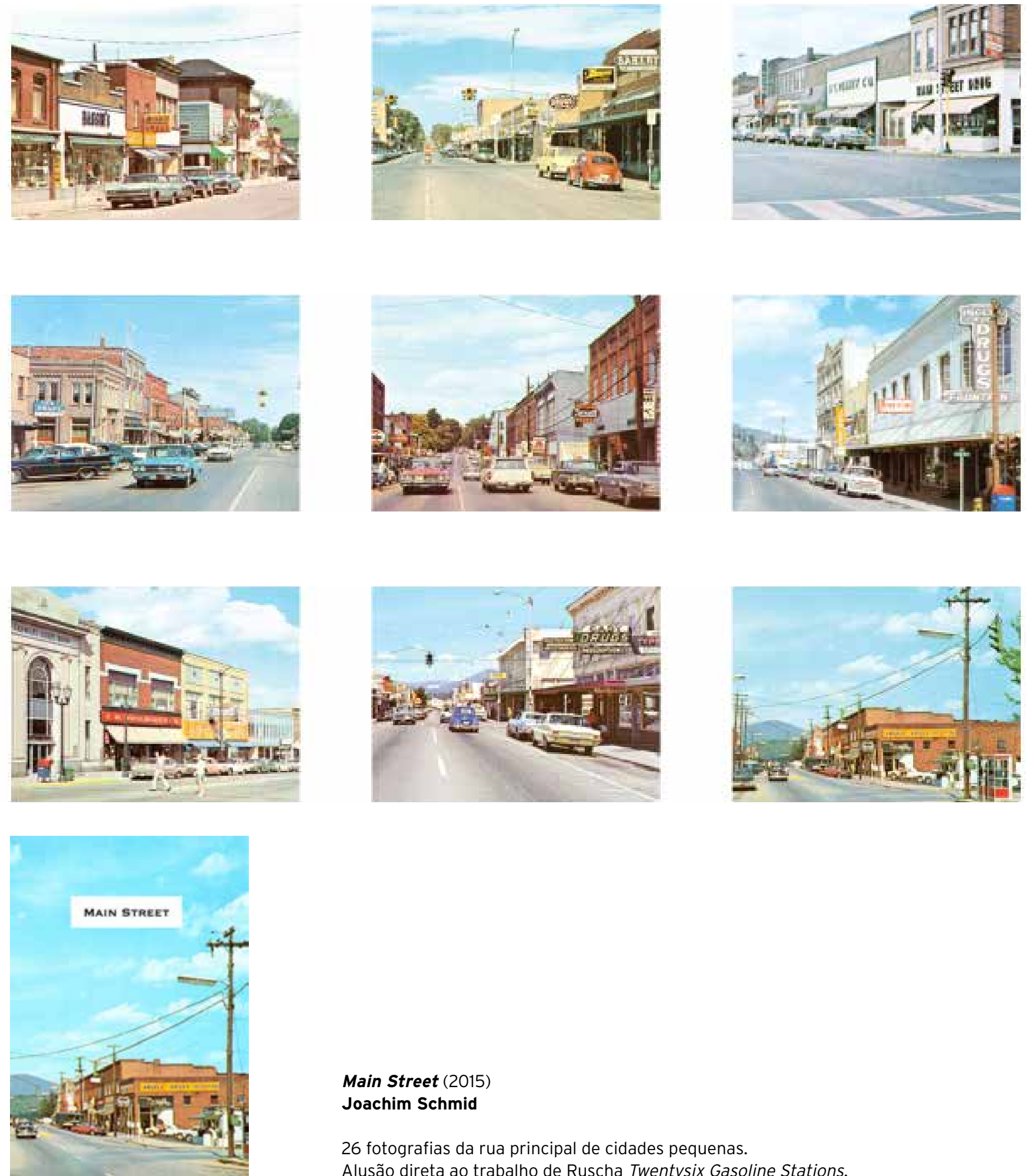

Main Street (2015)

Joachim Schm

26 fotografias da rua principal de cidades pequenas.

Alusão direta ao trabalho de Ruscha Twentysix Gasoline Stations. 

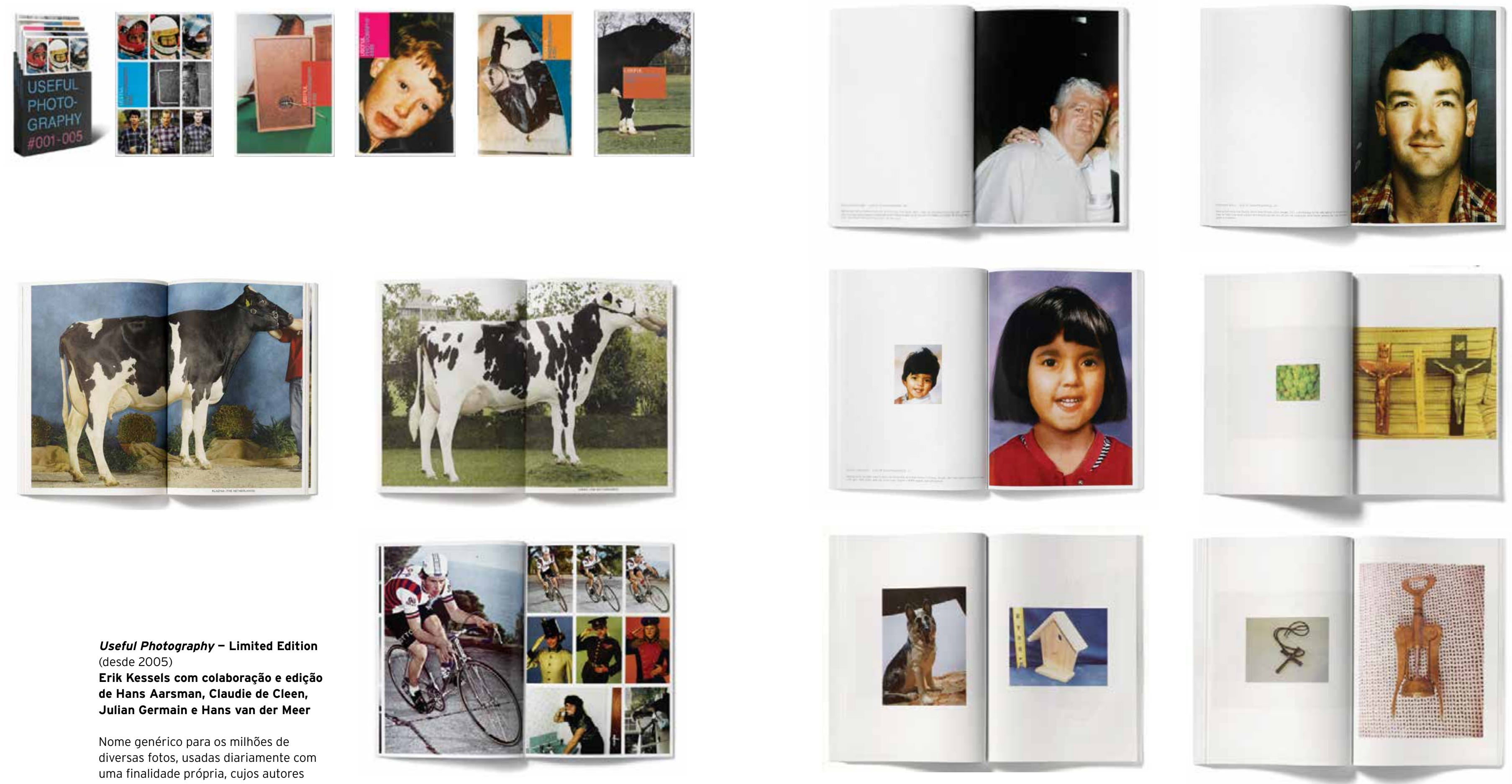

Useful Photography - Limited Edition (desde 2005)

Erik Kessels com colaboração e edição Julian Germain e Hans van der Meer

Nome genérico para os milhões de diversas fotos, usadas diariamente com uma finalidade própria, cujos autores do seu contexto, as imagens produzem novos insights sobre o que é considerado fotografia útil. 


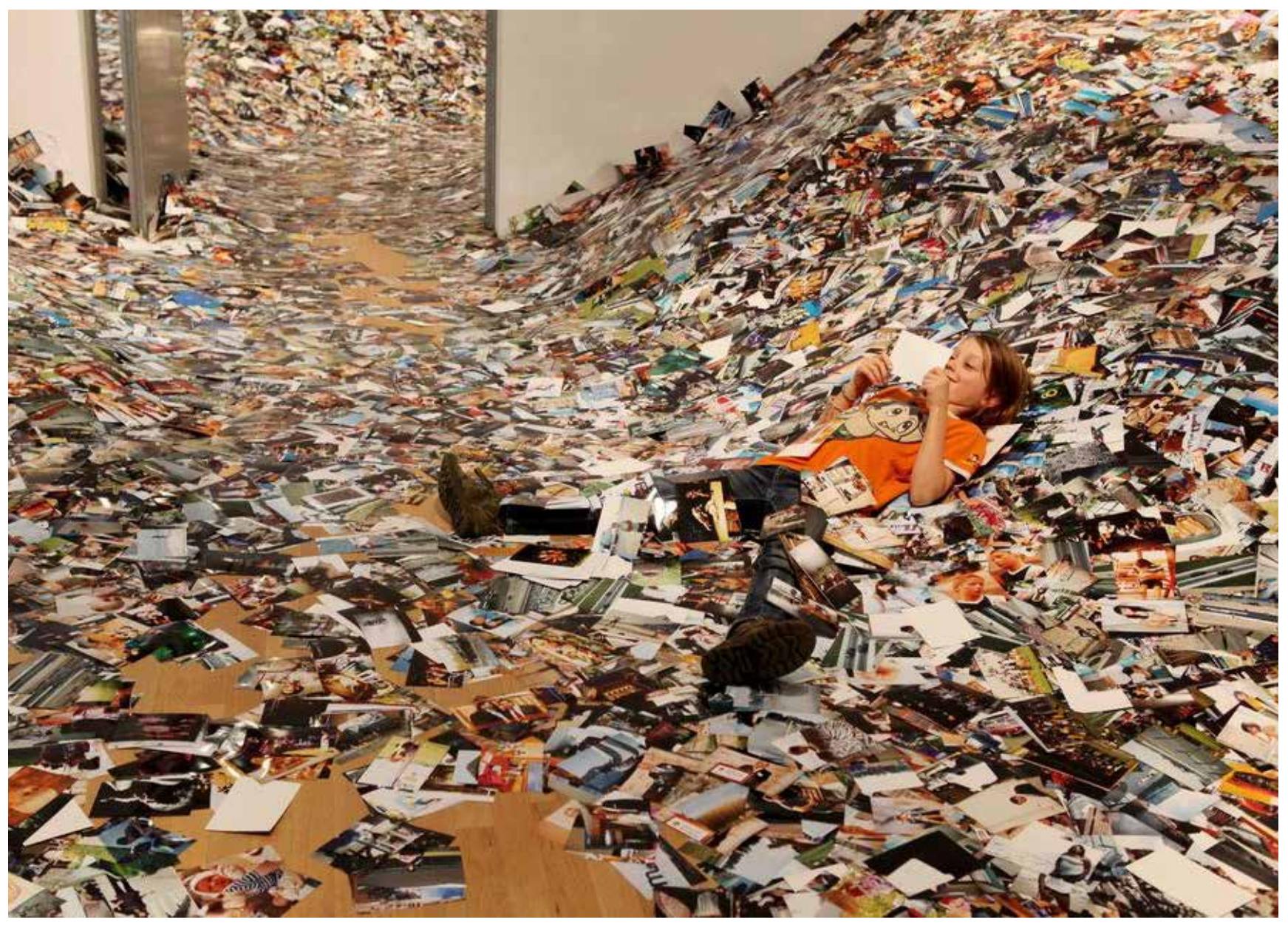

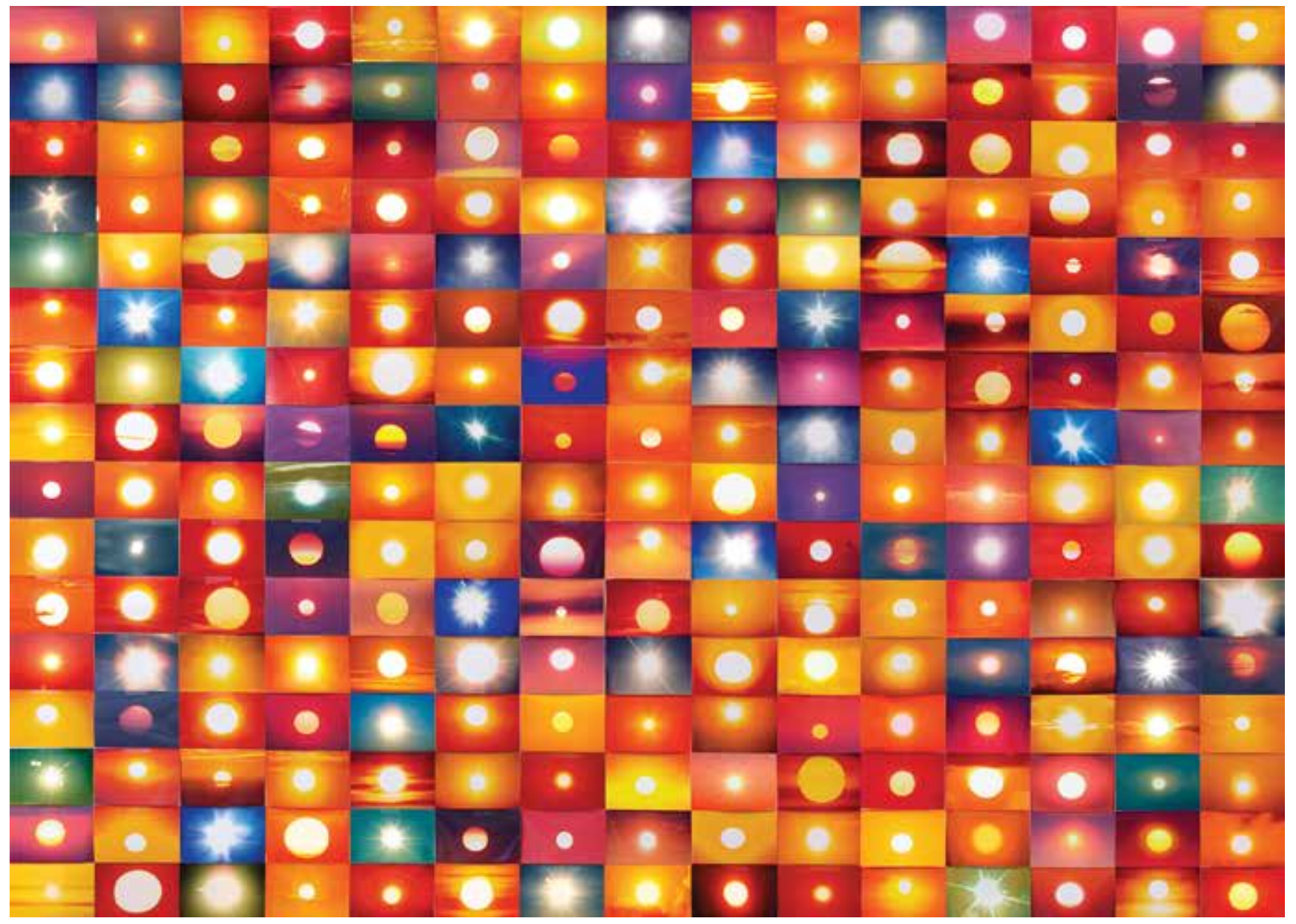

Suns from Flickr (2006)

Penelope Umbrico

Small Universe (2014)

Erik Kess

Este projeto começou quando a artista encontrou 541.795 imagens do pôr do sol ao procurar a palavra "sol" no Flickr. Ela captou e cortou apenas a imagem dos sóis e imprimiu-as no no Flickr no dia da impressão da peça. 


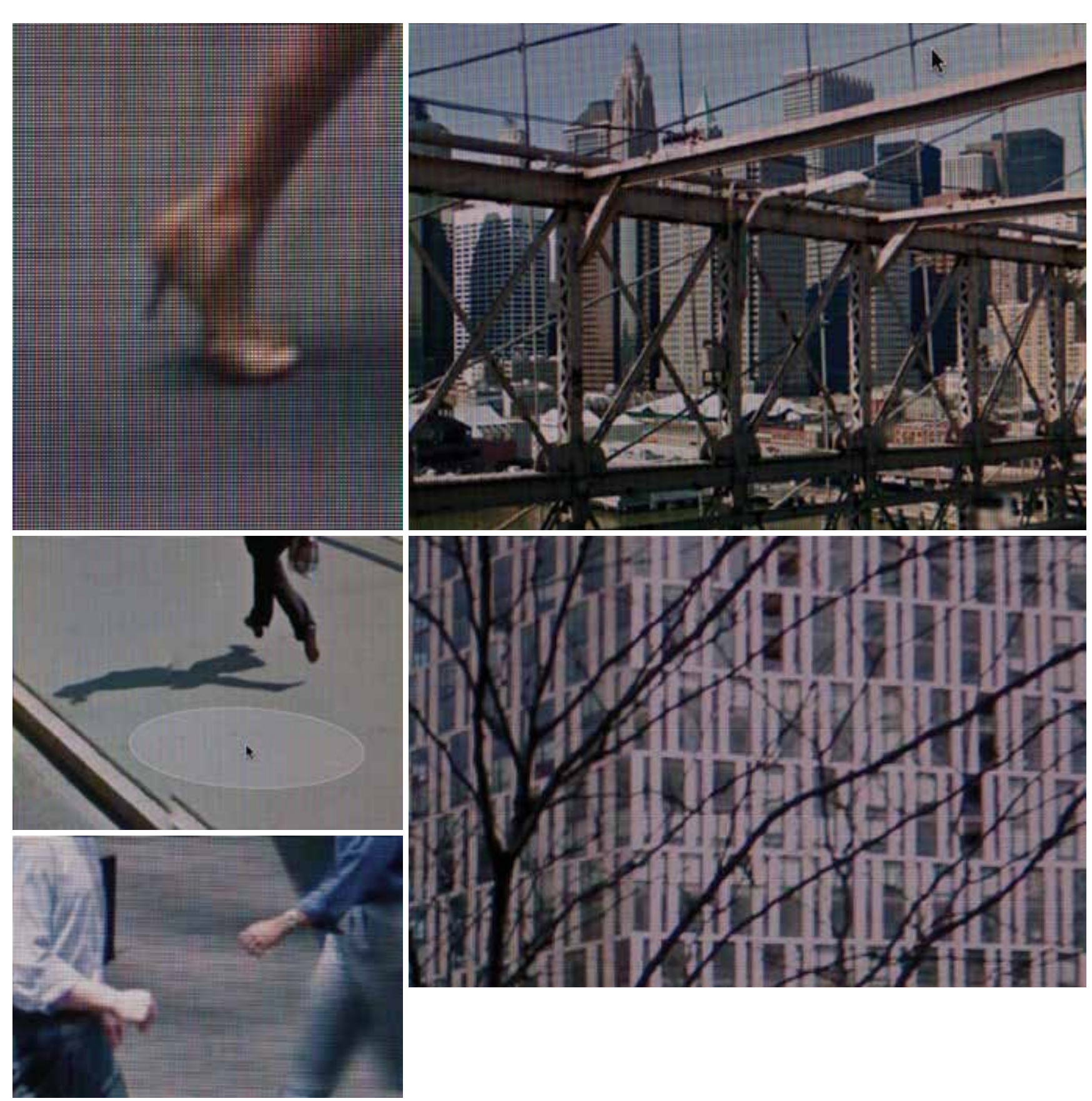

Google Street View: Manhattan (2011)

Michael Wolf

Séries fotográficas realizadas a partir de imagens capturadas do Google Street View. 0 artista lida com as questões de superprodução e veiculação de imagens na internet, visibilidade e opacidade, falta de privacidade e controle. E o irônico parodoxo de fotograr a rua sem sair de casa. 

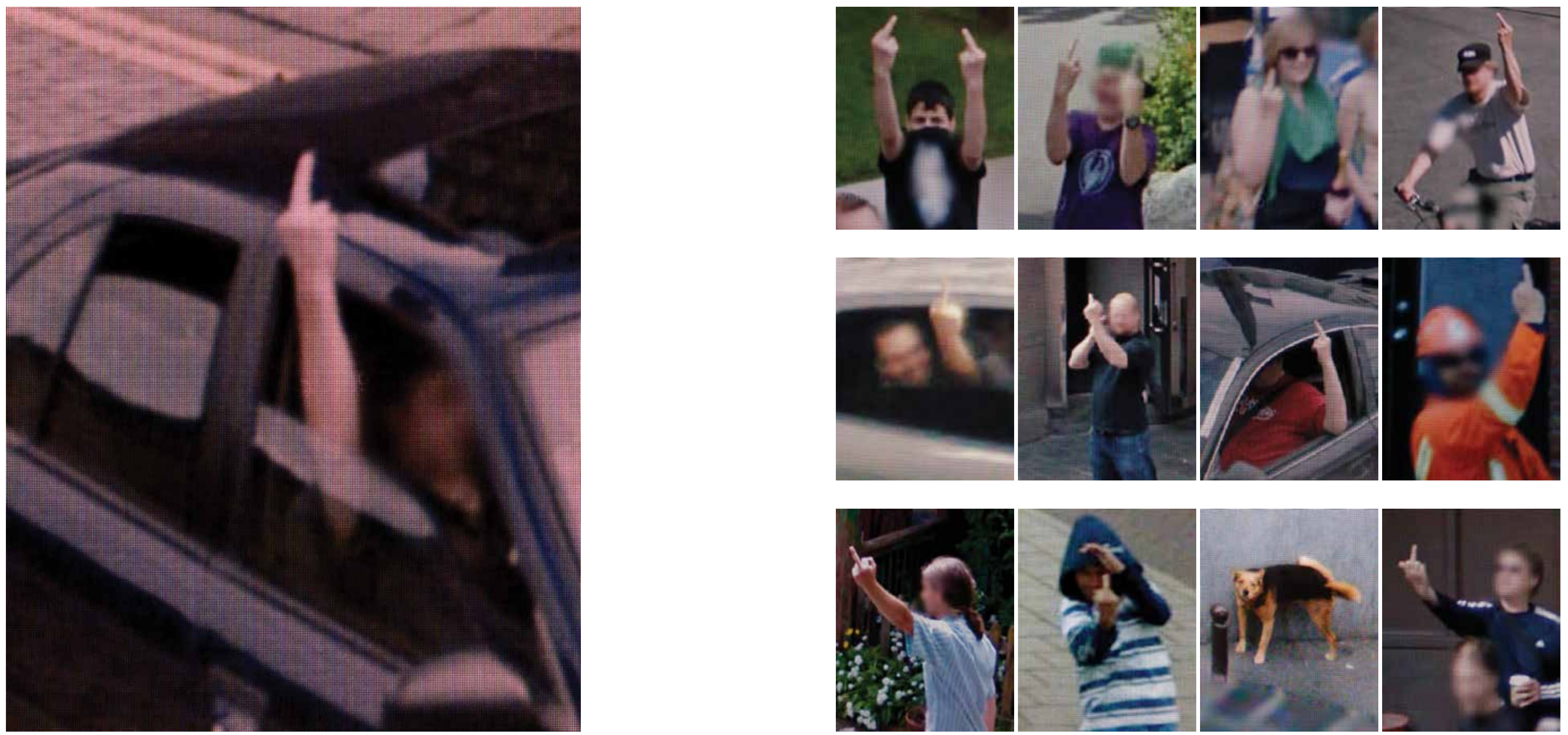


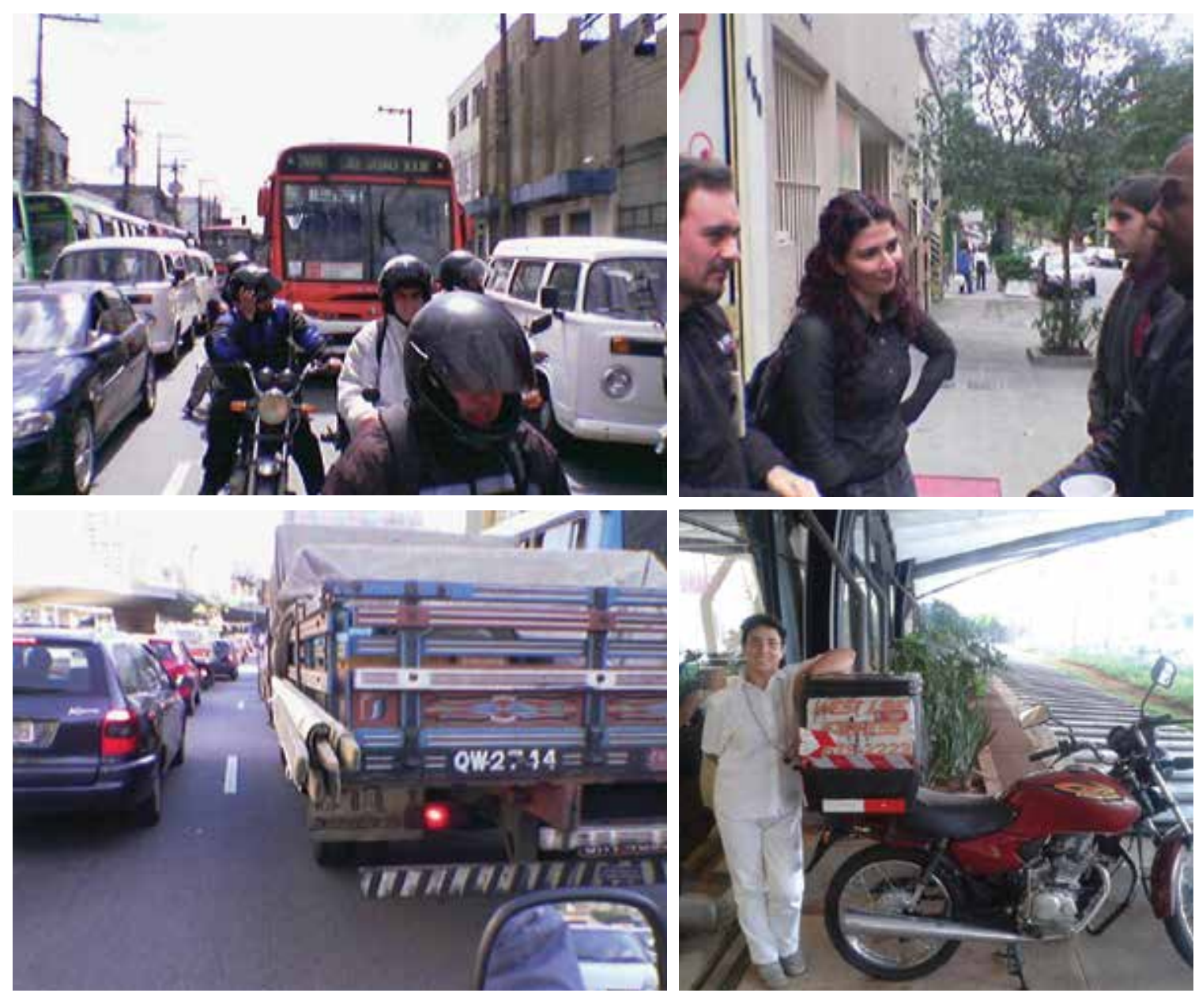

Canal Motoboy (2004 - 2015) Antoni Abad

Abad criou o Megafone.net, um canal de internet que dá voz a grupos discriminados socialmente, como taxistas na Cidade do México, imigrantes em Nova York e prostitutas em Madri. Na versão brasileira, o artista entregou celulares com câmera a motoboys de São Paulo para que registrasse 0 projeto ajudou a dar visibilidade ao grupo e redefinir alguns estereótipos.
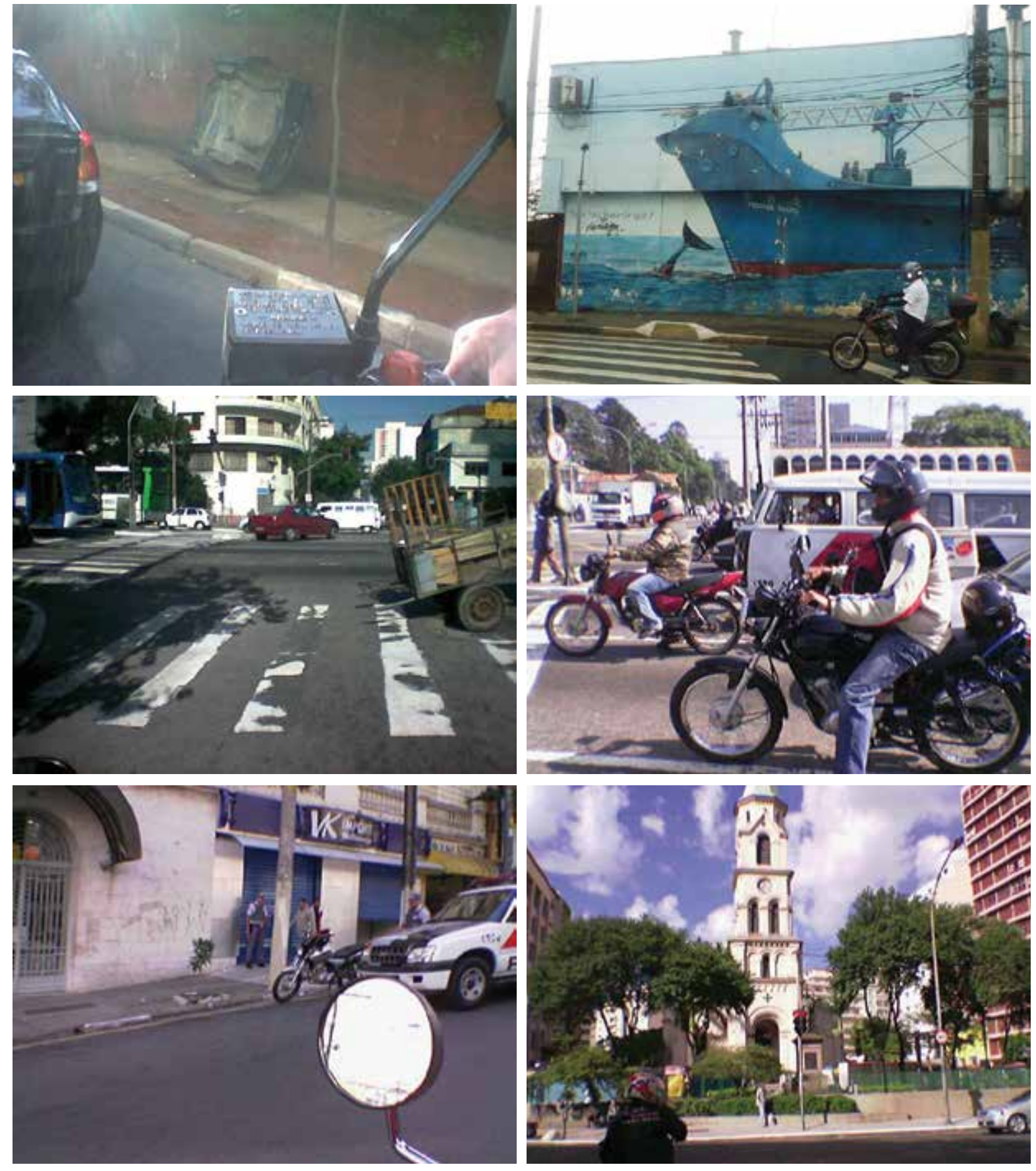

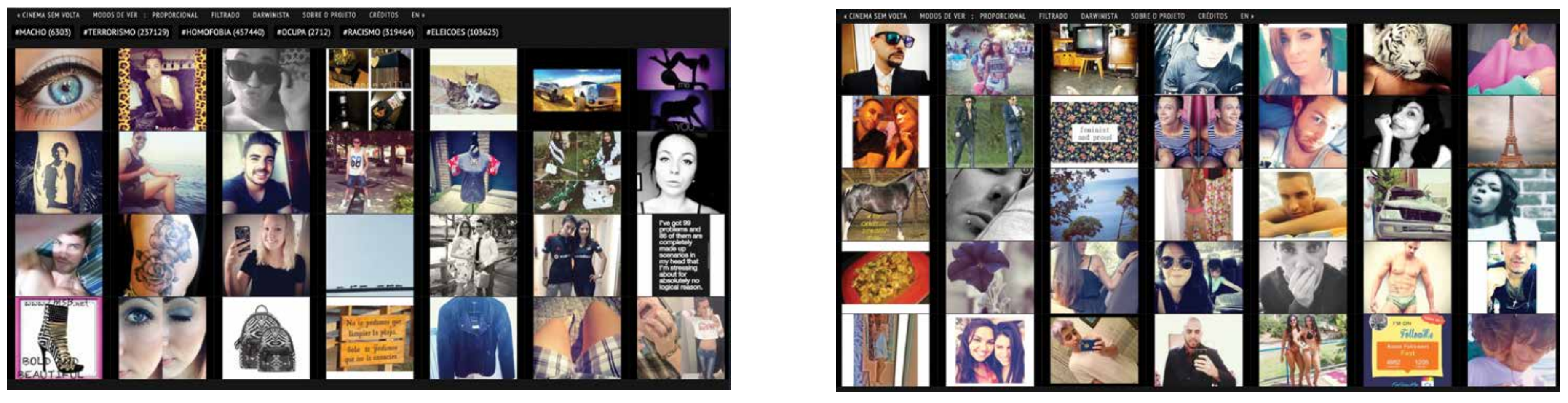

Cinema sem Volta (2014)

Giselle Beiguelman

Aproximadamente 2 milhões de imagens foram processadas ininterruptamente, para compor um mosaico dinâmico em um slideshow infinito sobre a batalha de linguagens que permeia a dimensão estética da experiência política contemporânea. Alimentado automaticamente com imagens do
Instagram produzidas por grupos conflitantes que utilizam as mesmas hashtags, perfomatiza as tensões entre a turba e a multidão.

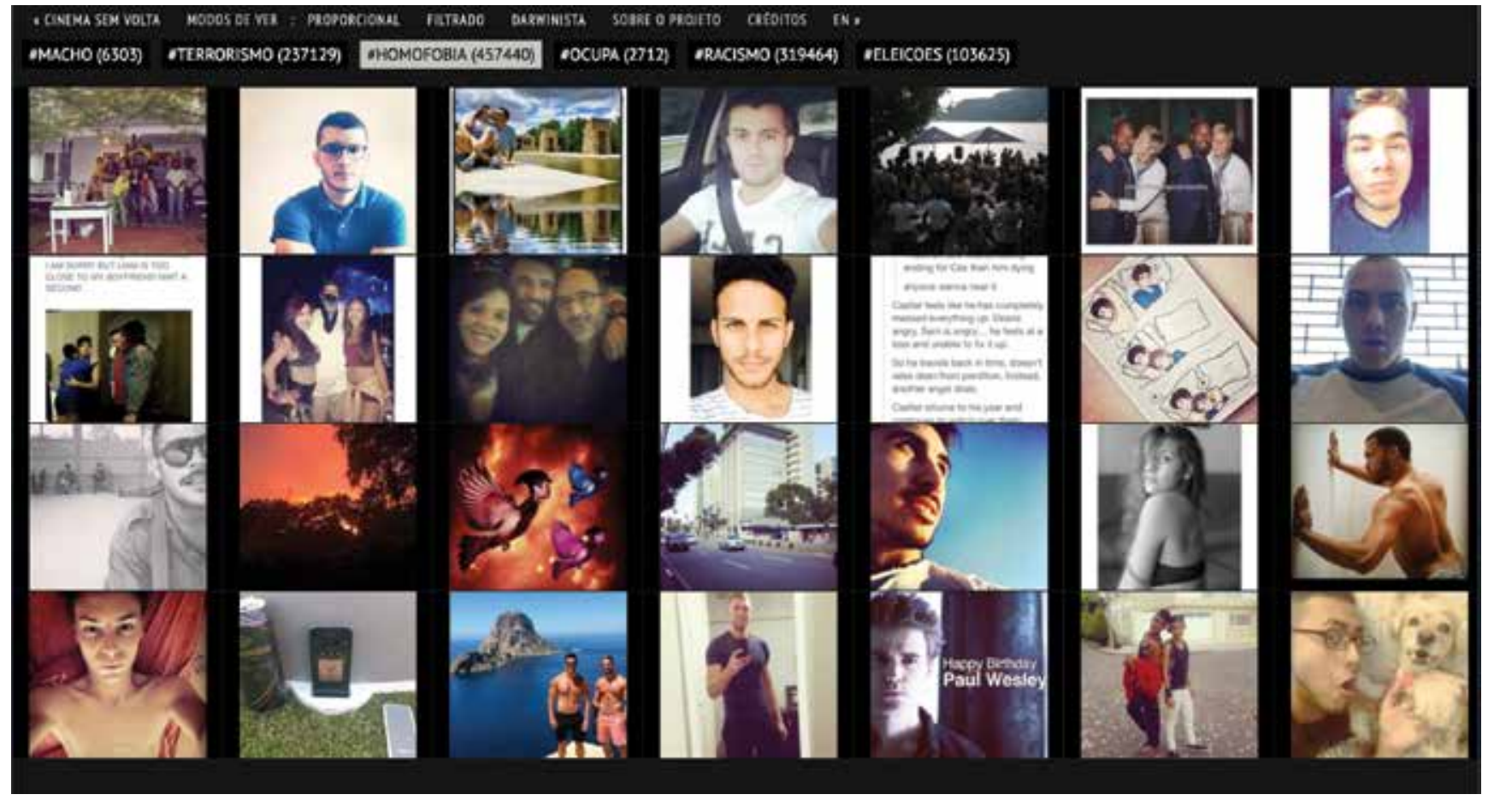




\section{A linguagem híbrida e o espaço cíbrido}

Podemos questionar, a partir do conjunto de trabalhos apresentados neste capítulo, se a percepção do espaço vivido pelo homem contemporâneo mudou ao longo dos anos. 0 binômio corpo e olho permanece o mesmo na apreensão estética das "coisas". E parece-nos natural ampliarmos as possibilidades de apreensão da paisagem e de manifestações no campo das artes visuais a partir do uso de dispositivos móveis.

Nossa relação com o espaço físico se transformou pela possibilidade de estarmos presentes em espaços cíbridos, conectados simultaneamente ao ciberespaço e ao lugar, ao que vemos ao caminhar, às coisas urbanas, à paisagem. Talvez a possibilidade de "entrar na paisagem", como descreve Smithson, com a câmera celular possa mudar nossa apreensão estética, pois imediatamente estamos mediando o que se vê, na medida em que a imagem é produzida, mediada e compartilhada/publicada imediatamente, na mesma tela do aparelho do dispositivo móvel. E temos ainda, dentro desse espaço cíbrido, para o bem ou para o mal, a possibilidade de viver numa mediação contínua, no espaço da rede, onde narrativas reais, surreais, metafóricas e, principalmente, dos afetos convivem diariamente, impulsionadas pelo próprio espaço urbano que passa do estado interativo ao participativo.

As narrativas de Michael Wolf, captadas pelo Google Street View, as narrativas de Dina Kelberman - realizadas também com imagens do Google - e as representações de On Broadway, de Manovich, apresentam um novo paradigma do "andar como prática estética". Não deixam de reafirmar um novo contexto informacional para esta frase: passeamos pelas redes, usamos de coordenadas geográficas para localizarmos as imagens e podemos inverter a lógica e as estratégias dos passeios quando estamos no ciberespaço. E é nesse território informacional que são geradas as imagens de uma miríade de trabalhos que se utilizam da estética das redes como resultado formal.
Voltando à experiência híbrida do caminhante/artista com o uso de dispositivos móveis: o olhar sob o ponto de vista do pedestre é algo inerente do homo sapiens. Olhar, apreender e documentar a paisagem urbana, por meio de câmeras celulares, faz parte da estetização da vida cotidiana (RANCIÈRE, 2013), do cidadão urbano. $E$, no meio dessa superprodução de imagens, de construção de cartografias afetivas de cada cidadão, há a potencialidade de construção de poéticas visuais, que operam no âmbito político, cultural e artístico.

O próximo capítulo, Imageria urbana, dará continuidade a essa arqueologia de narrativas visuais. É uma publicação que pode ser lida separadamente do conjunto desta pesquisa, pelo seu viés poético. Reúne a edição de ensaios coletivos e individuais de imagens mobile capturadas do aplicativo Instagram, organizadas a parti da coleção de imageria da pesquisadora. Representa um conjunto heterogêneo de apropriações e jogos de composição de narrativas urbanas de São Paulo. 


\section{FONTES DE IMAGENS}

https://megafone.net/site/index http://www.desvirtual.com/multitude http://photomichaelwolf.com $\mathrm{http}: / /$ kesselskramerpublishing.com http://robertsmithson.com

http://blogs.getty.edu/iris/new-acquisition-ruscha-sees-la/\#sthash.rLBDlupX.dpuf https://schmidbooks.wordpress.com http://phaidon.com/agenda/photography/articles/2014/july/03 http://dinakelberman.tumblr.com/ http://grahamfoundation.org/public_exhibitions/3878-las-vegas-studio-images-from-the-archives-ofrobert-venturi-and-denise-scott-brow http://warburg.library.cornell.edu/ 
Imageria e poéticas de representação da paisagem urbana nas redes

imageria urbana - \#x 


\section{Imageria urbana - \#x}

Este conjunto de imageria urbana constitui a principal referência para o processo metodológico desta pesquisa: falar de imagens por meio de imagens. Investigamos a natureza e o contexto da imagem mobile a partir de paradigmas teóricos (capítulos 1, 2 e 4) e a partir de uma abordagem prática, de edição, apropriação e diagramação de narrativas visuais compiladas nesta publicação.

O processo de seleção, classificação e edição das imagens deste caderno iniciouse de forma completamente manual, cognitiva, sensorial e estética. 0 ponto de partida foi uma inquietação sobre a estética da imagem produzida e veiculada nas redes e a relação do olhar do caminhante, autor e portador de uma câmera celular, com a rua e a representação da paisagem urbana. A partir de um processo de colecionismo de "print screen" (captura de telas) de posts do Instagram selecionados desde junho de 2012, formamos uma "imagérie" da cidade de São Paulo. A depuração, organização e edição dessas imagens desenvolveu-se dois anos depois, como a principal fonte de pesquisa para uma investigação acerca dessa imagem produzida, mediada e veiculada pelos dispositivos móveis nas redes sociais, especificamente no Instagram.

A singularidade da linguagem imagética em pauta está imbricada com o movimento do corpo, do olho e da câmera "como um terceiro olho na palma da mão" (BEIGUELMAN, 2011). Envolve a comunicação em tempo real das redes e a contaminação da esfera individual pela coletiva. $O$ uso desse dispositivo de produção de linguagem dá visibilidade ao cotidiano, ao ordinário, e potencializa movimentos de ativismo social e cultural, conecta o cidadão e convida-o a relacionar-se de outra maneira com o ciberespaço e com a paisagem que o cerca. Essa conexão entre estética e participação social e política, tema tratado por Bourriaud (2011), Rancière (2009) e Lipovetsky (2014), conforme vimos no capítulo 1, gera uma miríade de produção imagética sem precedentes. 
A princípio, a deriva urbana debordiana parecia responder à questão principal do projeto, de problematizar a poética da imagem mobile por meio de narrativas subjetivas, produzidas e associadas ao caminhar pela cidade. O livro Walkscapes: o caminhar como prática estética de Careri - para quem “caminhar é um instrumento estético capaz de modificar os espaços urbanos, preenchidos de significados, de coisas" (CARERI, 2013, p.28), impulsiou o projeto e direcionou a pesquisa para uma estratégia de mapeamentos etnográficos do nômade contemporâneo (FOSTER, 2014).

No início, o foco do garimpo fotográfico eram séries autorais que representassem imageticamente a cidade de São Paulo e operassem no campo da narrativa da imagem sequenciada, fragmentada, editada e mediada pelos dispositivos móveis e pelas redes sociais. Imagens que, por meio da percepção visual do autor, conseguissem ressignificar um lugar, um território ou um objeto arquitetônico. Podiam estar condicionadas à memória, à história, ao afeto, a experiências sensoriais e estéticas, a circunstâncias políticas, sociais, culturais, emocionais. Começamos pela coleta de imagens de alguns fotógrafos profissionais que estavam usando a rede Instagram para divulgar ensaios pessoais. Entretanto, após investigação do arsenal de recursos tecnológicos disponíveis nos aplicativos das câmeras celulares (uso de filtros, emulação de filmes negativos, lentes aclopáveis ao visor do aparelho celular, filtros de pós-produção etc.), esses ensaios passaram a ser vistos como uma abordagem extensiva da fotografia fine-art reproduzida em livros de arte e em exposições, editadas em outro suporte. Ou seja, era a mesma poética da fotografia tradicional, na sua essência, publicada de forma fragmentada em uma nova interface.

O uso de dispositivos móveis, nesta investigação, apresentou-se então como uma ferramenta adicional para produção, mediação e veiculação imediata de fotografia digital, uma "evolução" da arte contemporânea na incorporação das mídias digitais. Era preciso mergulhar no território informacional e nas especi- ficidades do aplicativo para correlacioná-los com a estética e a poética da imagem mobile.

A partir dessa constatação adotamos a investigação do uso de estratégias tecnológicas intrínsecas ao próprio dispositivo do aplicativo Instagram. Com base nas referências teóricas sobre o uso da tecnologia e das redes na arte (Beiguelman, Flanagan, Steyerl, Paul, Vesna), assumimos a vertente mais tecnológica das narrativas das redes, na chave da artemídia: o uso das hashtags (tags precedidas pelo símbolo \# que funcionam como palavras-chaves personalizadas), bem como o uso dos elementos geolocalizadores - identificados com o ícone do "pin" - e a possibilidade da junção de fragmentos imagéticos monotemáticos.

A estratégia de trabalhar com os algoritmos, como método de pesquisa para a busca de imagens, ampliou substancialmente o campo da pesquisa e sobretudo o recorte e o desenho desta edição de imagens. Assumimos o \# como o grande elemento organizador das narrativas. Surgiram centenas de imagens, organizadas em metanarrativas sobre a paisagem urbana de São Paulo. Entre elas, para citar apenas algumas, \#copan, com 47.369 imagens do edifício, mais 8.675 posts marcados com o pin de geolocalização "Copan"; \#cicloviapaulista (2.519 posts); e \#parqueminhocão (1.939 posts).

Com base nessa estética dos bancos de dados (VESNA, 2007), a coleção de imageria ganhou um outro viés, no qual a autoria da imagem perdeu relevância. Trata-se de narrativas construídas por fragmentos de muitos artistas anônimos. O foco estava no artista comum, na partilha do sensível do "qualquer um" (RANCIÈRE, 2003) e na ressignificação do espaço urbano contemporâneo - o lugar de produção cultural. 0 contexto da pesquisa tornou-se mais narrativo e textualizado, na medida em que as buscas partiram de códigos algorítmicos (palavras-chaves) relacionadas à temas urbanos. A apropriação e o caráter coletivo apareceram como grande característica dessa nova linguagem narrativa. 
No meio de tantas narrativas coletivas, passamos a pesquisar artistas que se utilizam da estratégia do "\#"e driblam o default do aplicativo, criando verdadeiras narrativas visuais personalizadas. Essas imagens distribuídas em galerias virtuais, desvinculadas dos espaços institucionalizados das galerias e museus, inserem essa prática na linha evolutiva da artemídia.

As edições e apropriações das narrativas aqui selecionadas traduzem o processo de depuração das imagens que no fluxo midiático da rede transcendiam o lugar-comum e o código inscrito. São imagens que operam em outro nível de percepção, estão organizadas a partir de posts fragmentados, postados em diferentes dias, reconectados e apropriados a partir da intersecção entre as hashtags, os pins de geolocalização e os nomes dos autores, artistas amadores ou profissionais. 0 uso do \# e da palavra (dado algoritmo) como elemento organizador será aprofundado no capítulo 4, a partir do conceito da "frase-imagem" de Rancière (2013).

Essas narrativas visuais representam a cidade de São Paulo e revelam o ethos do homem contemporâneo. Aqui as fronteiras do espaço onde trocamos nossas experiências, a cidade real e os espaços informacionais não existem. Prevalece a poética e a estética das redes.

Ensaios coletivos, configurados como camadas narrativas temáticas relacionadas a acontecimentos, ativismo político lugares ou temas específicos da cidade de São Paulo. Representam a partilha do sensível do cidadão na sua deriva cotidiana. 


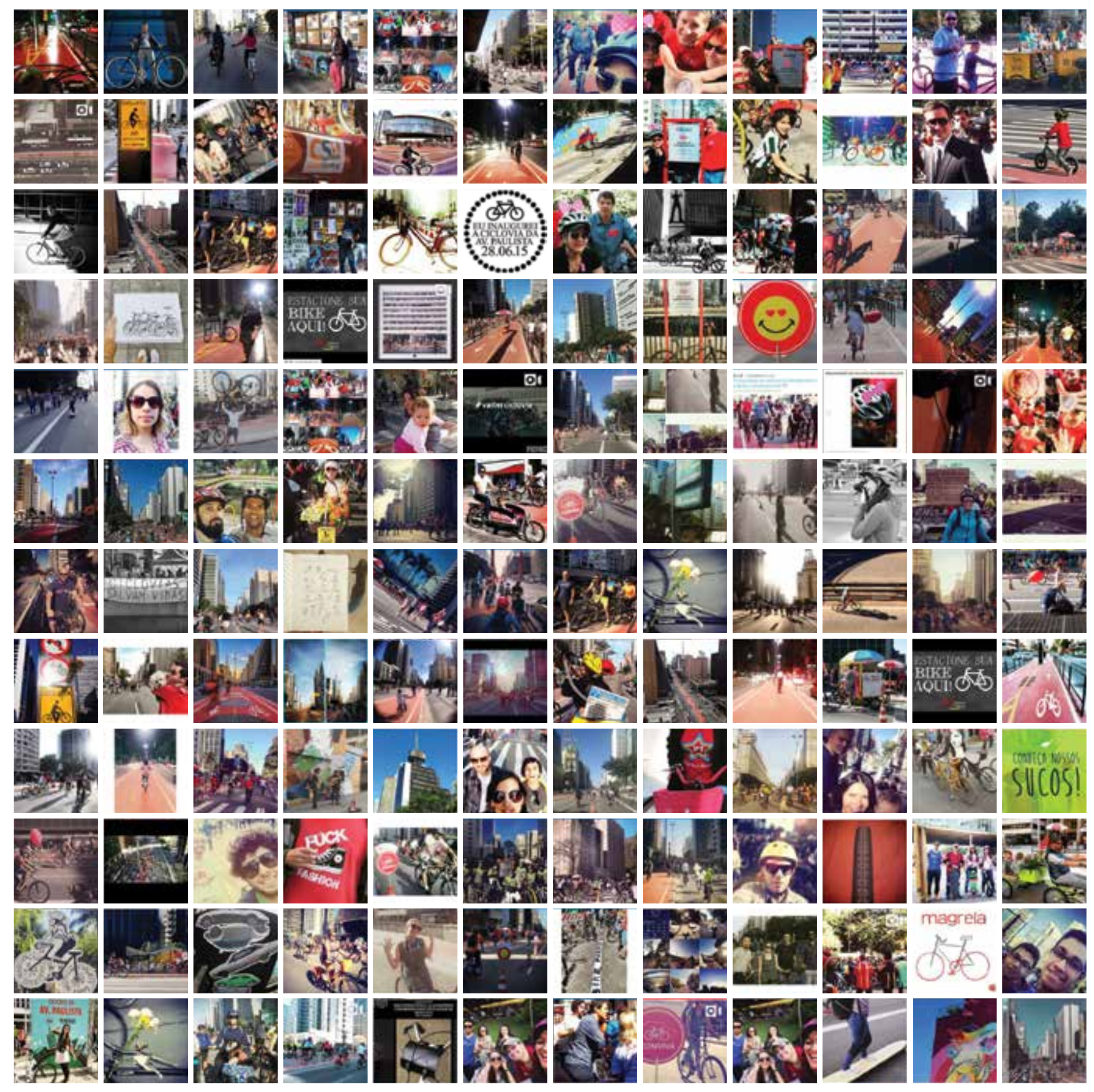

\#ciclovianapaulista

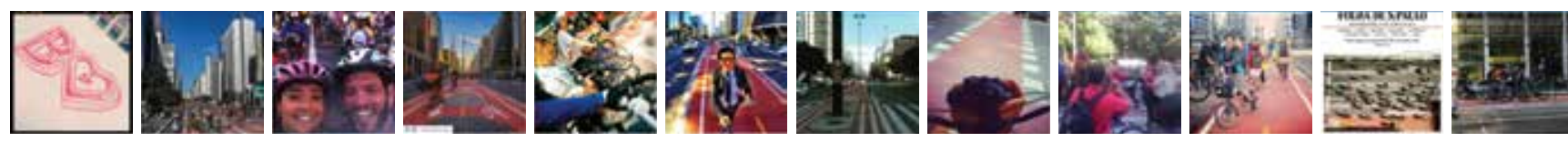

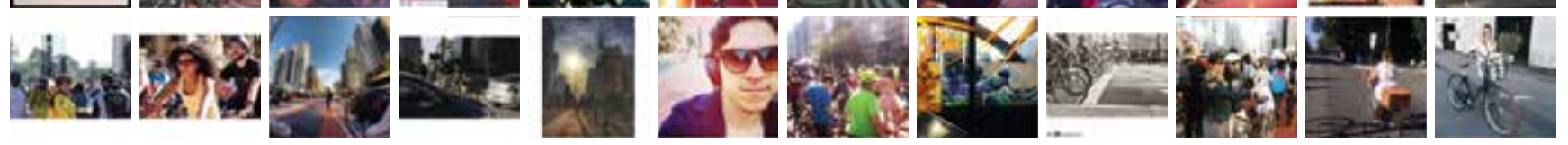

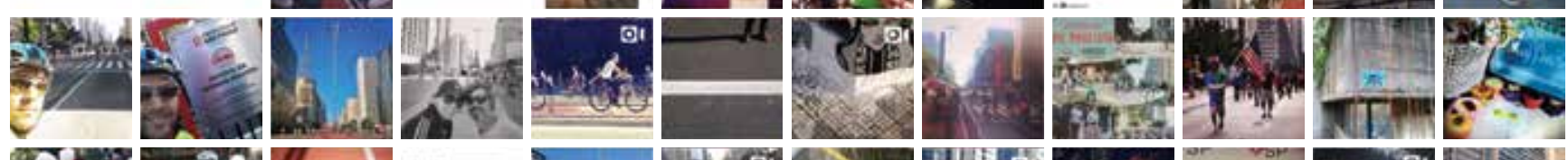

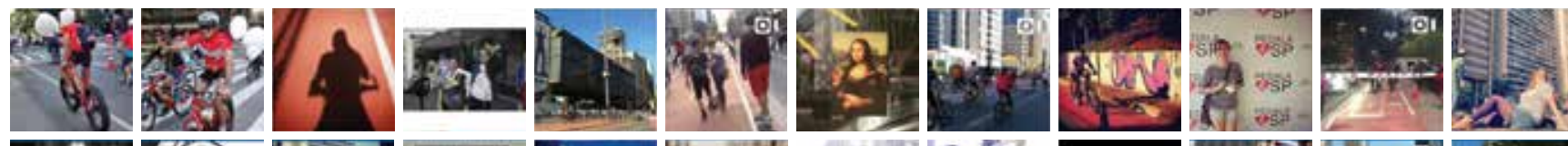

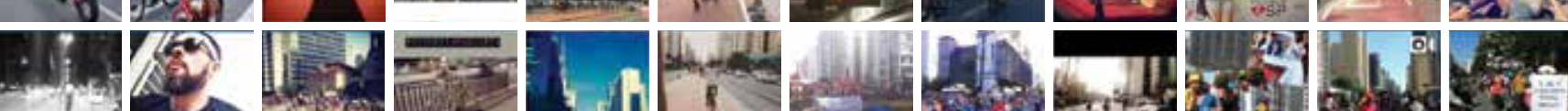

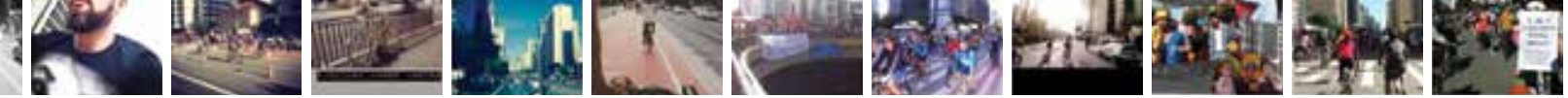

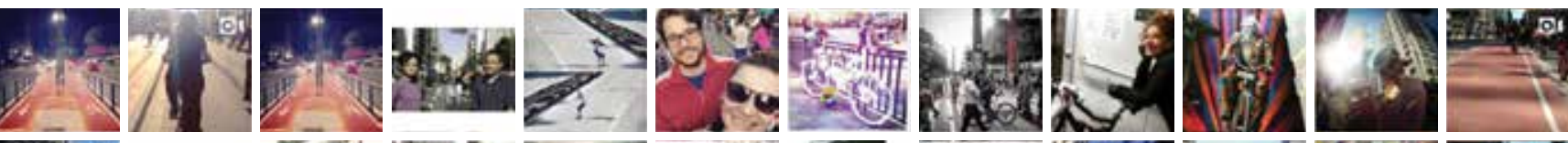

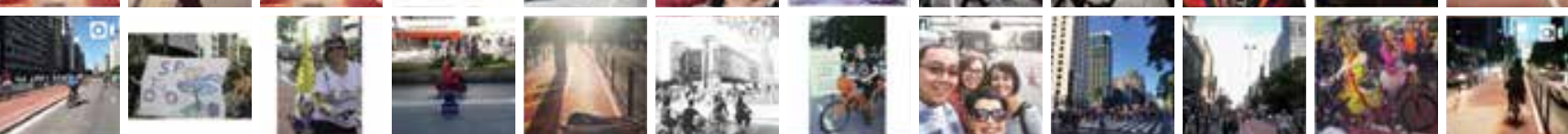

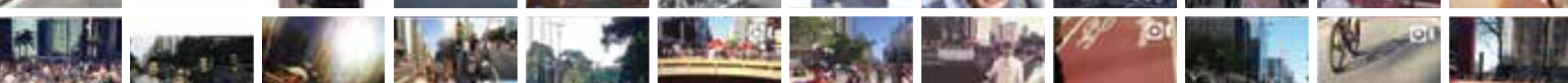

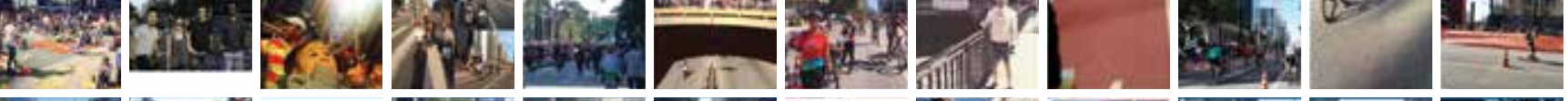
Tib4)

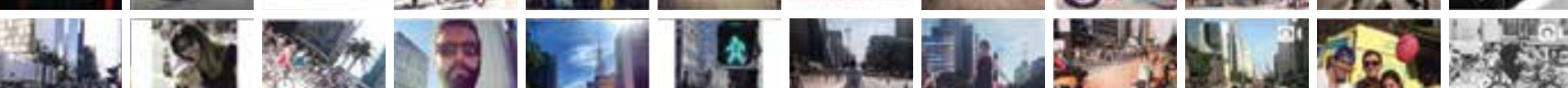

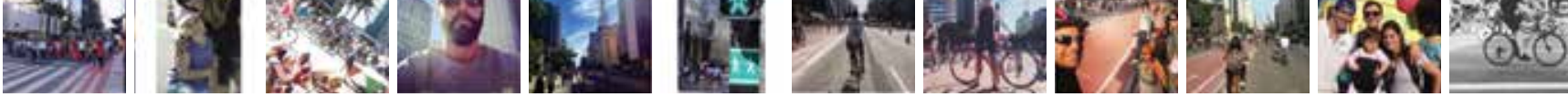

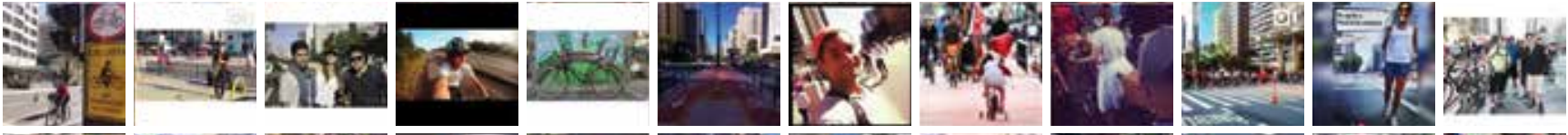

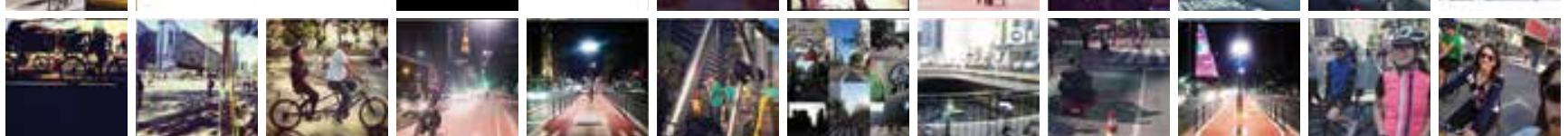


A H.

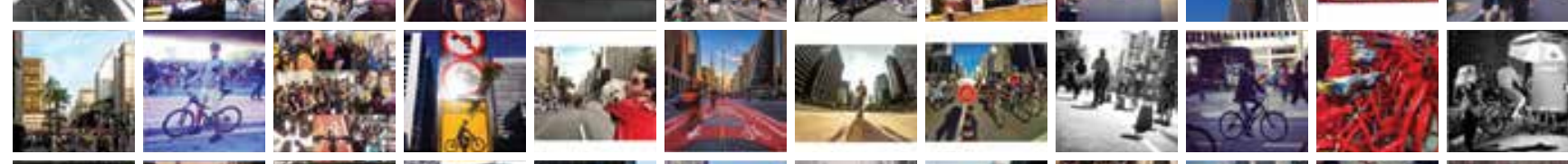

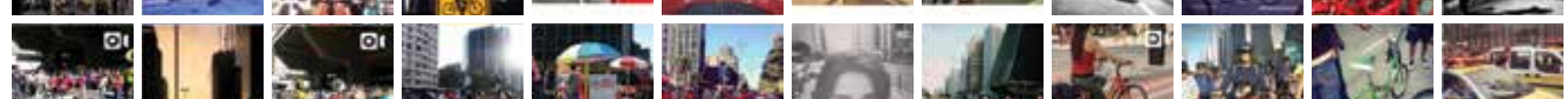

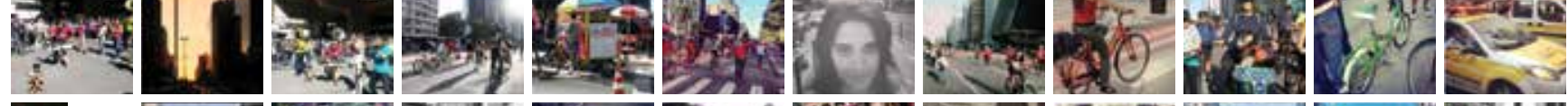
V D.

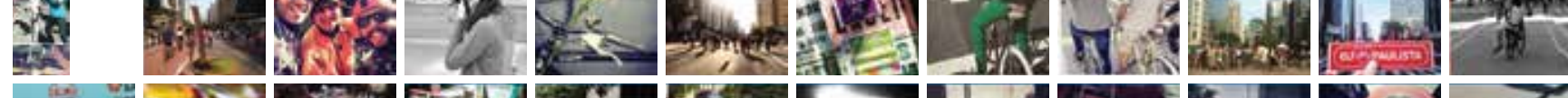

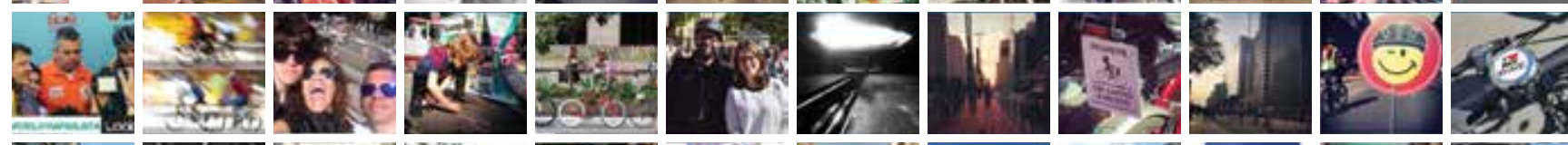
46. 7 I0.

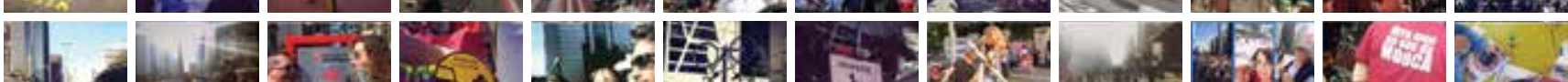
An Li

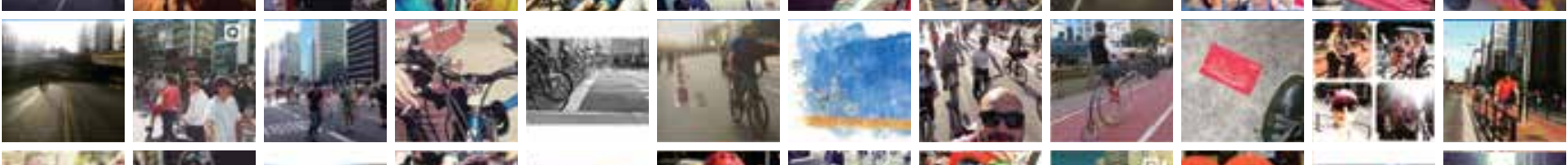

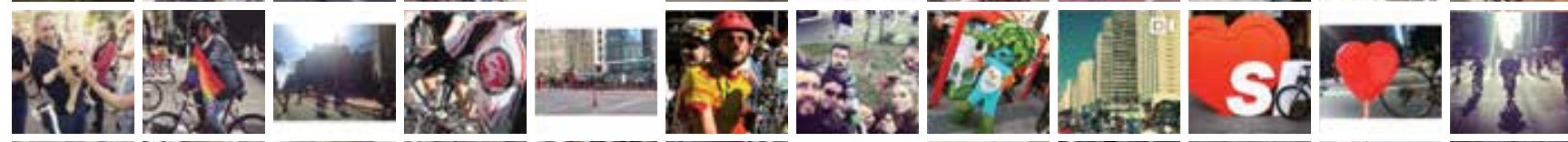
-

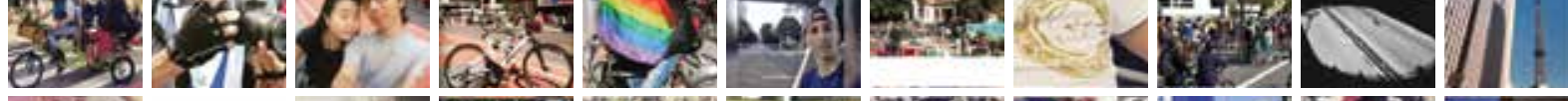

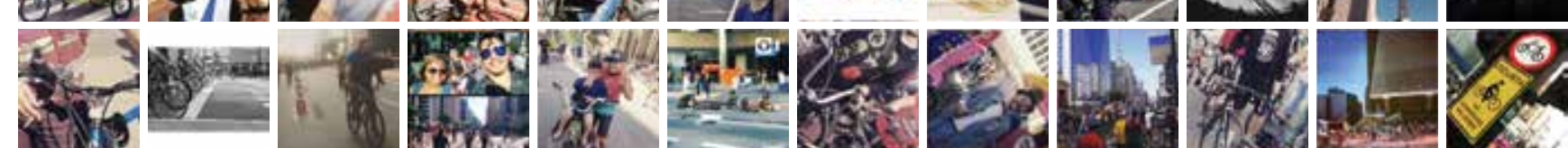

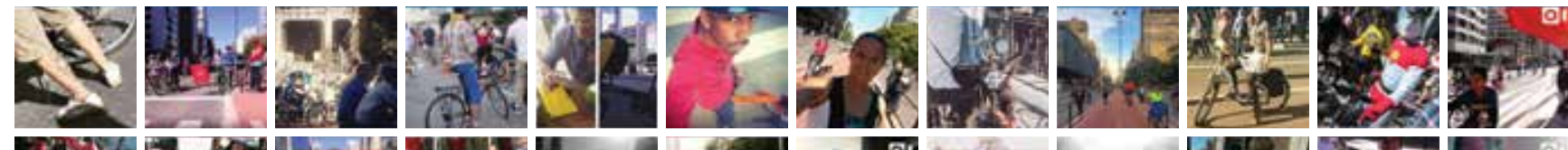
F⿻十

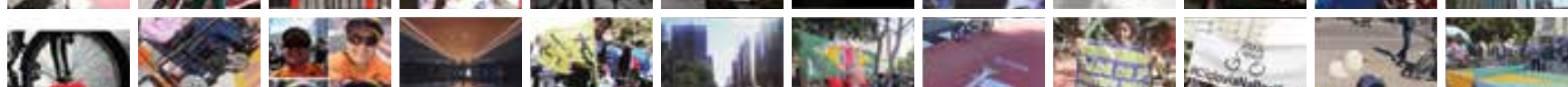

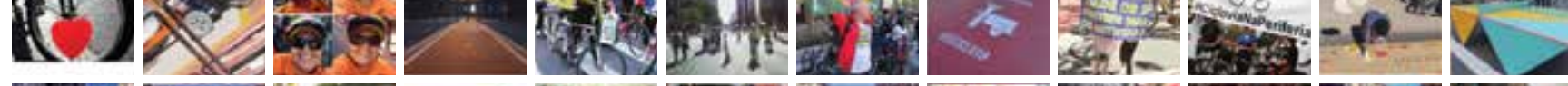

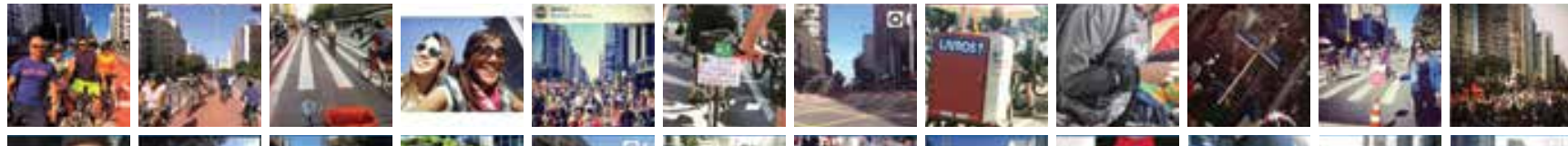

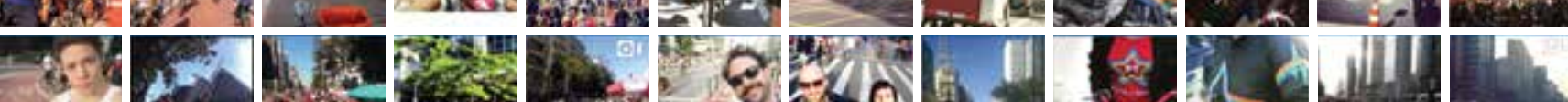

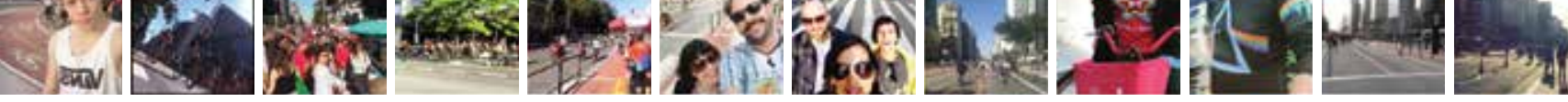

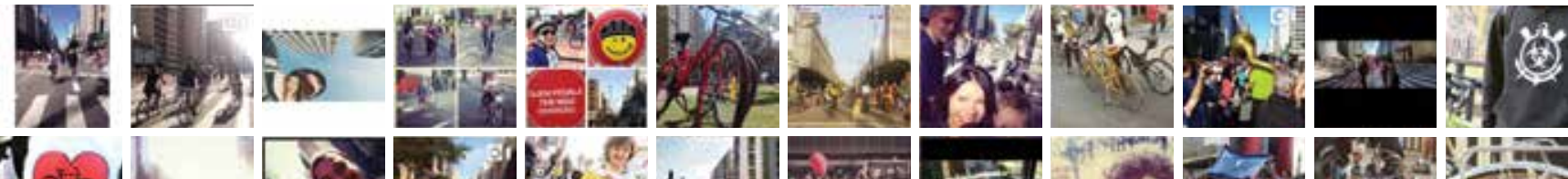

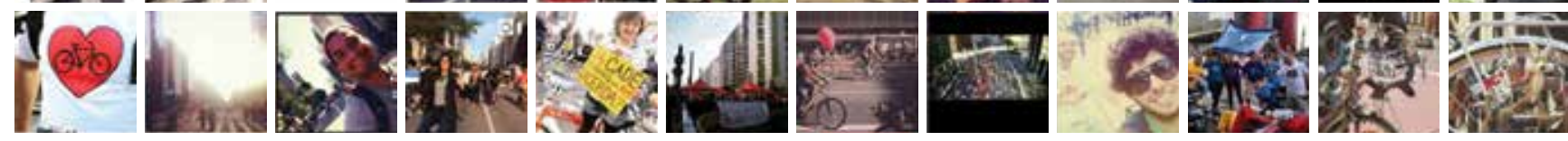

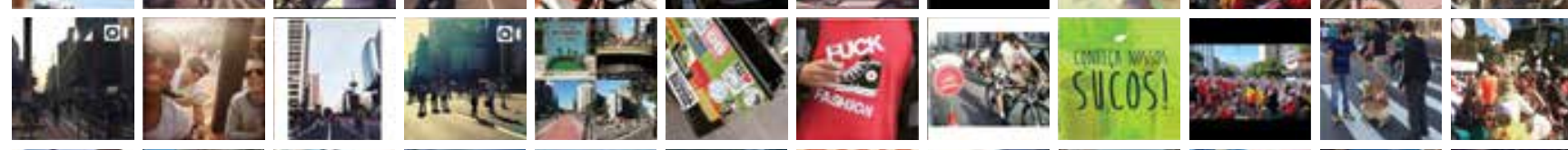

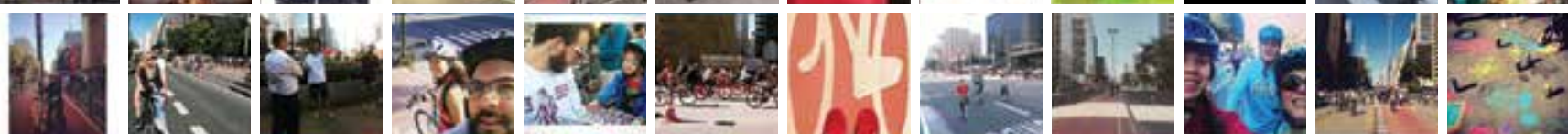

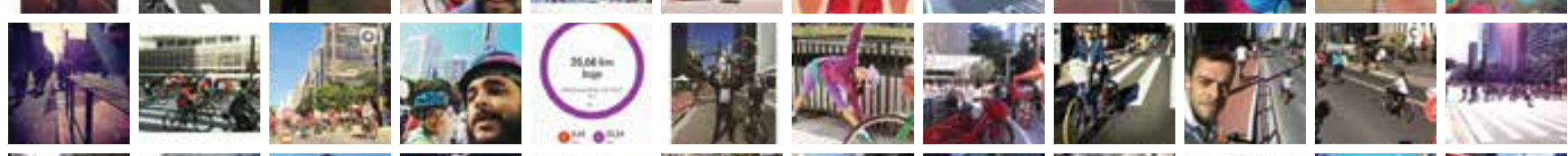

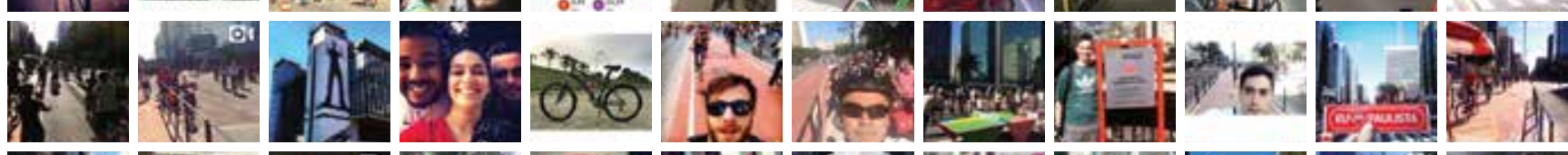

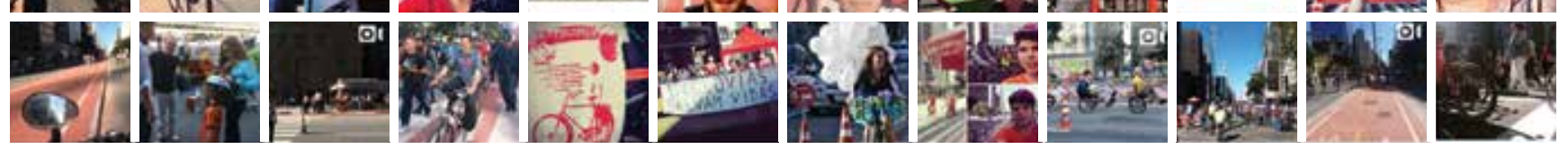



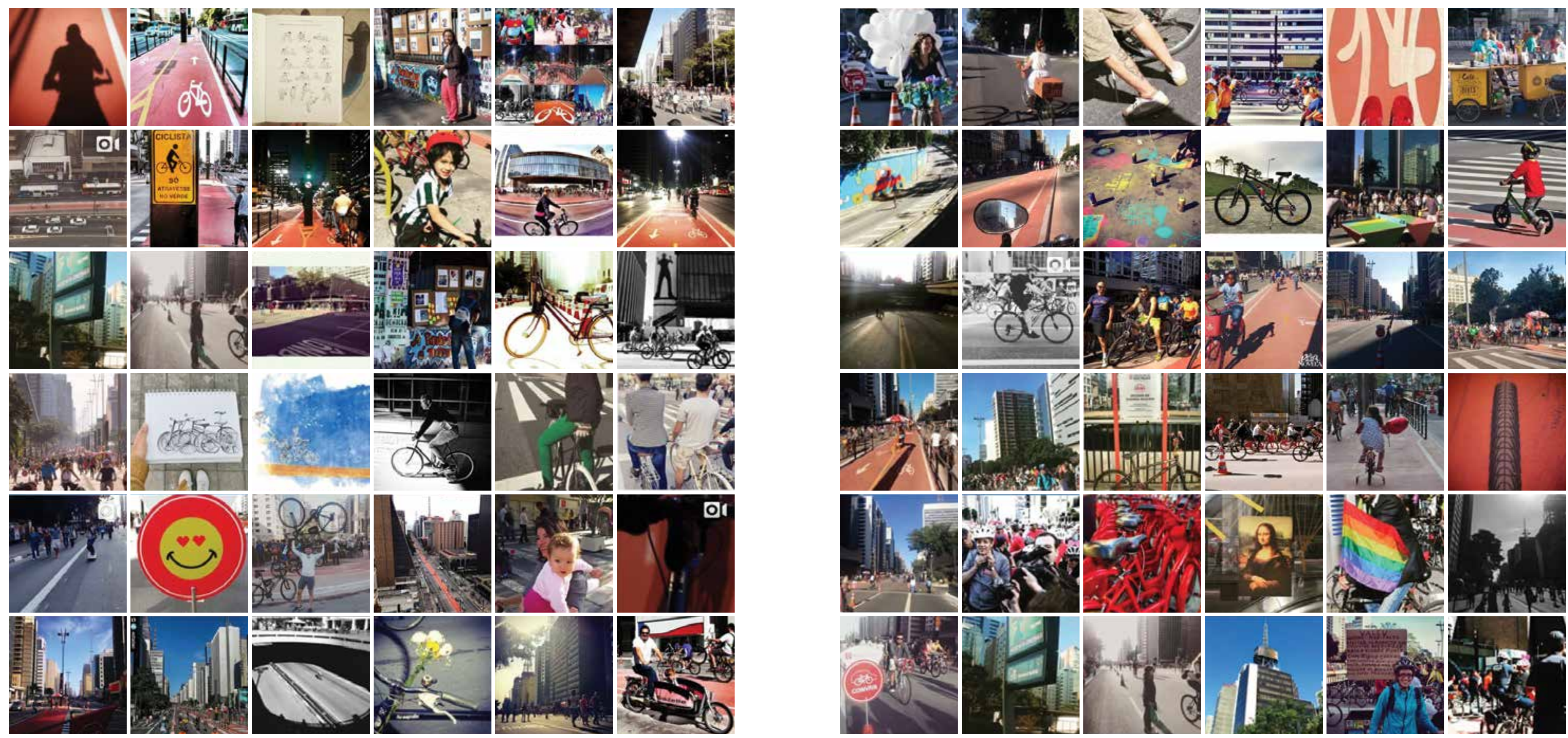

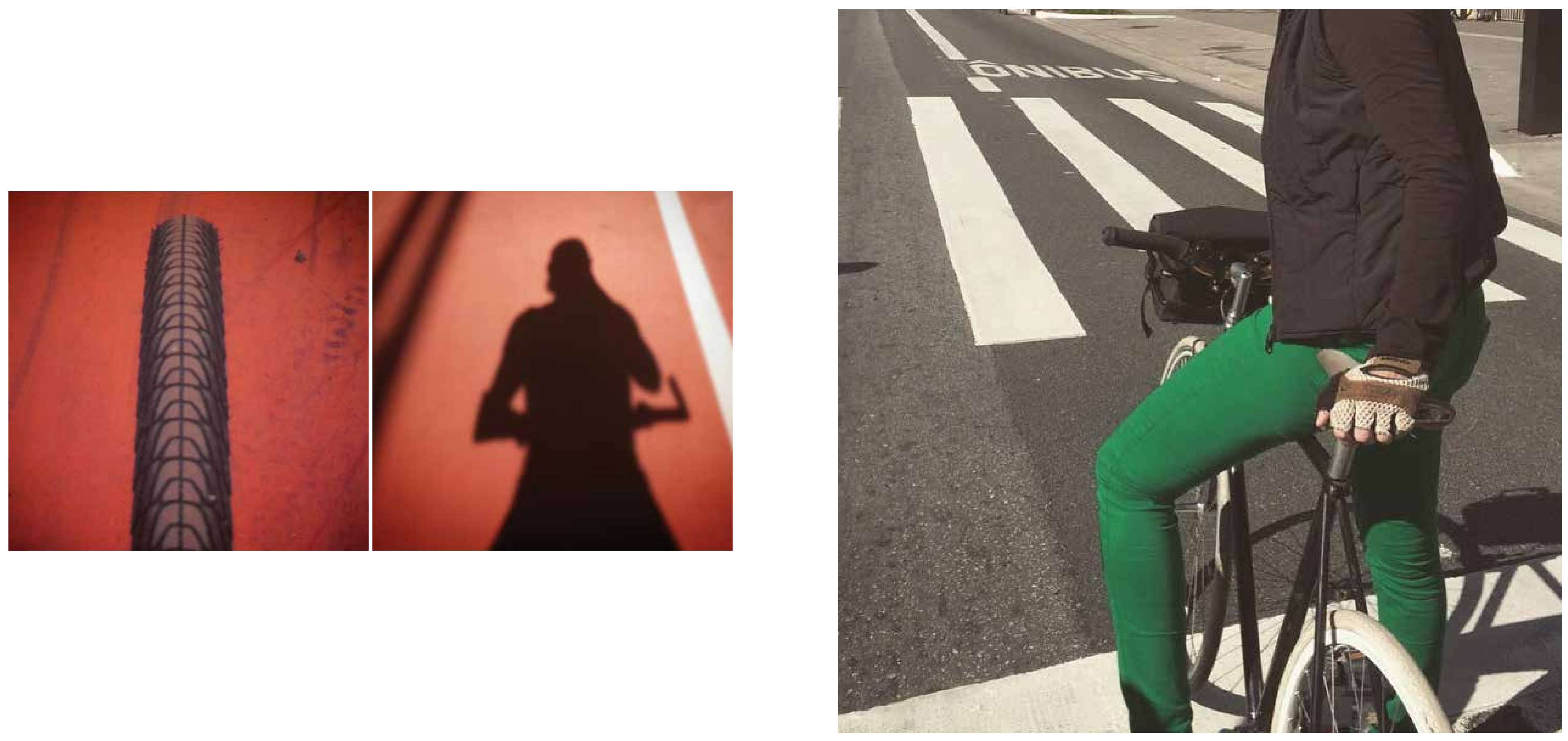

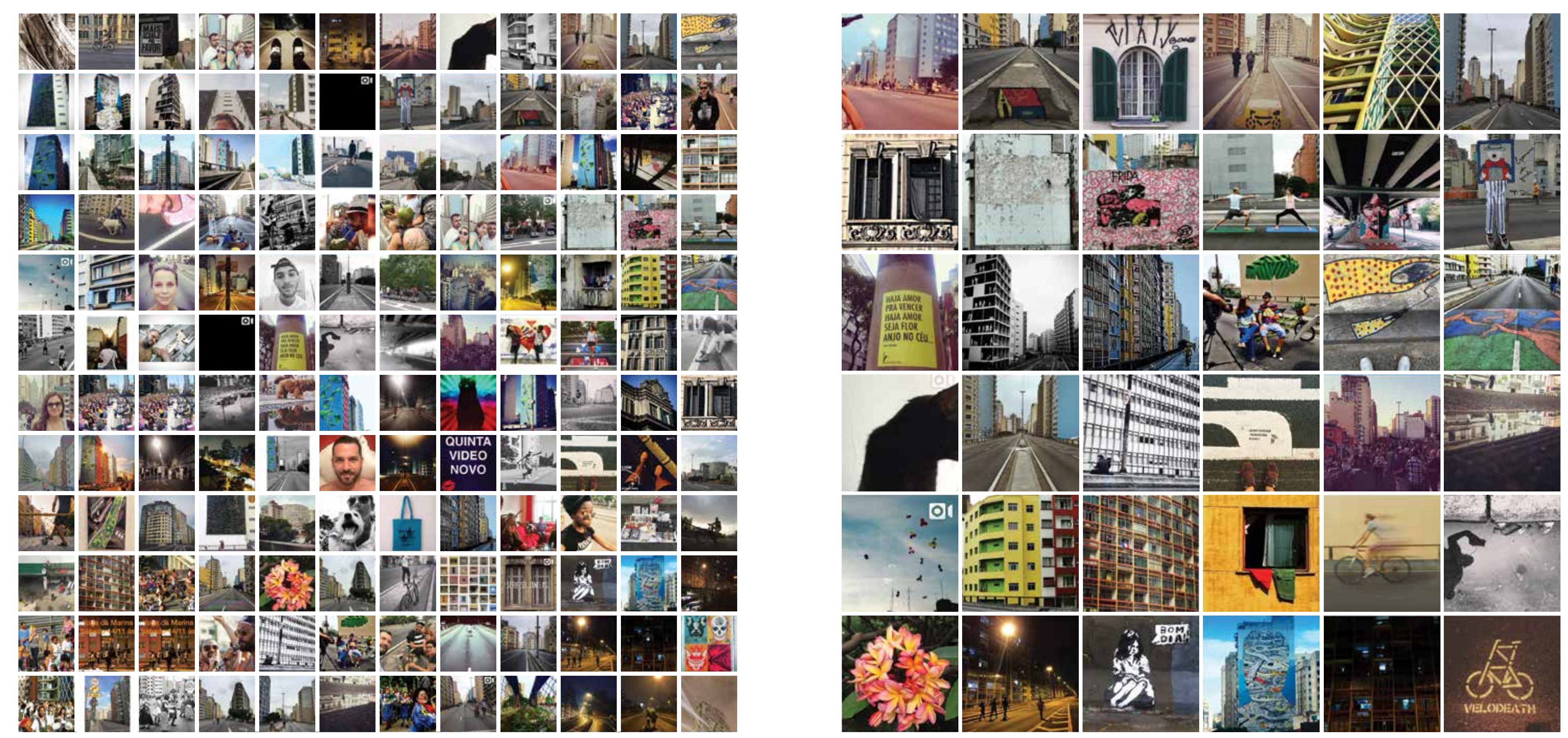

\#parqueminhocao 

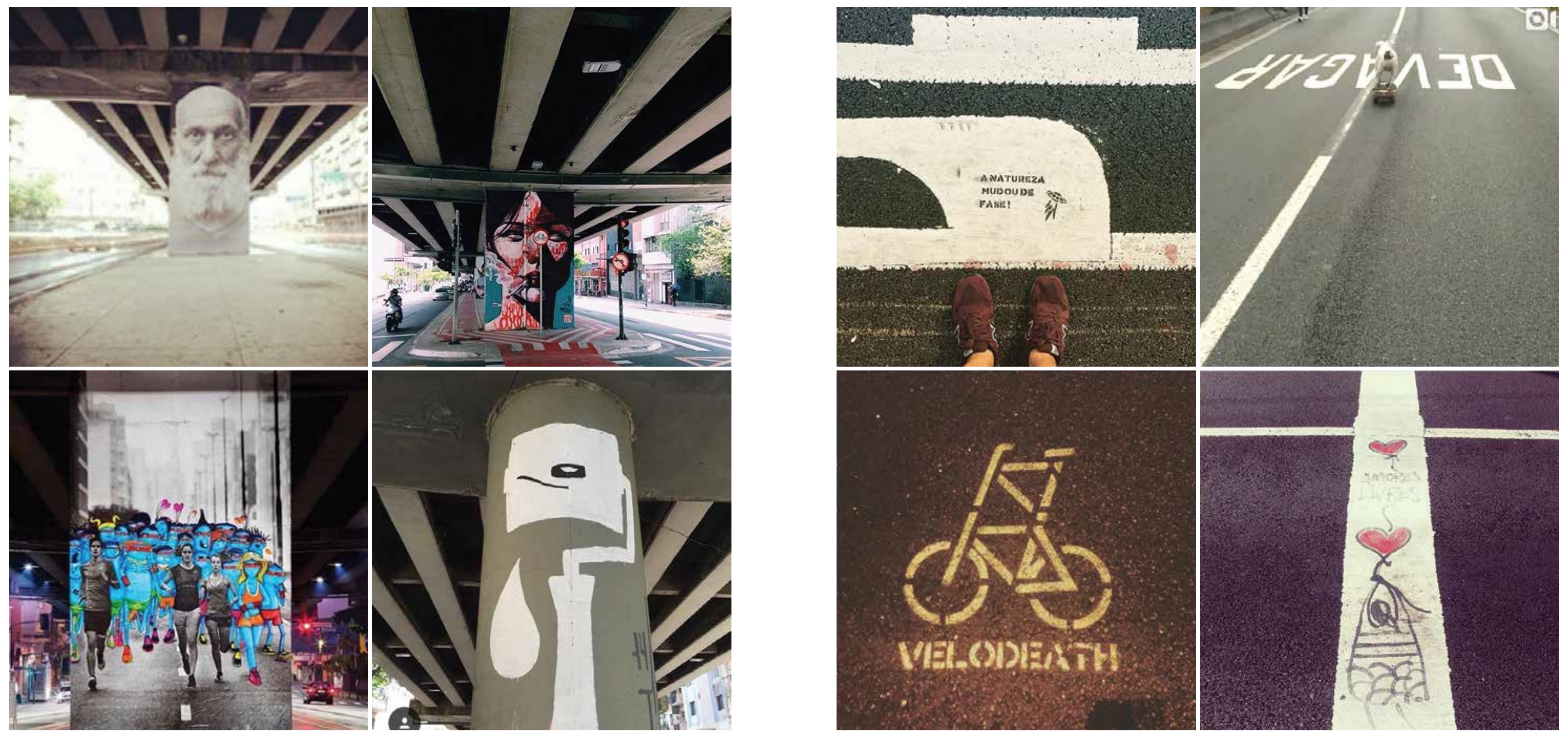

AV. São João: arte urbana nos pilares do viaduto Elevado Costa e Silva, já considerado Parque Minhocao para alguns. Edição realizada a partir do \#parqueminhocao. 

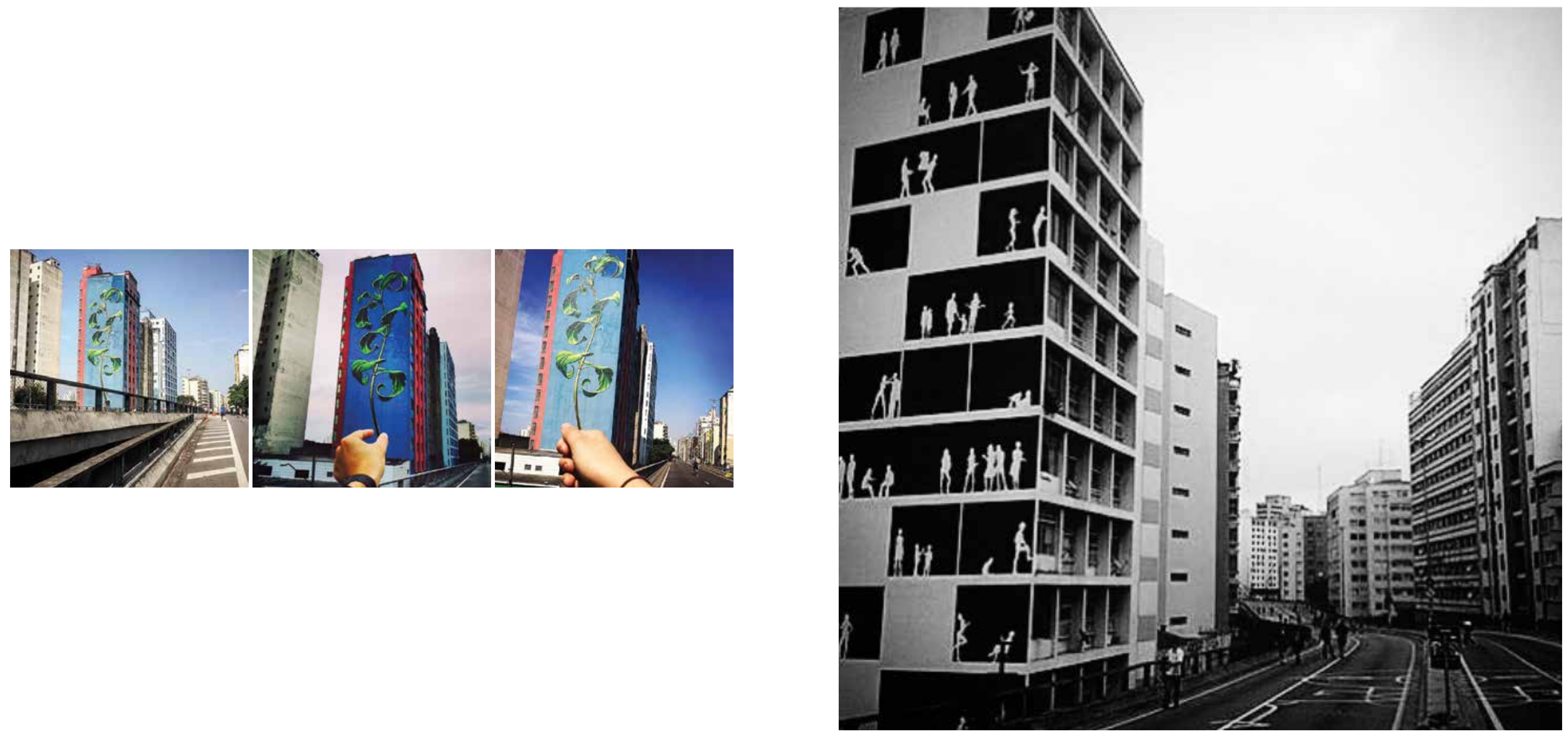

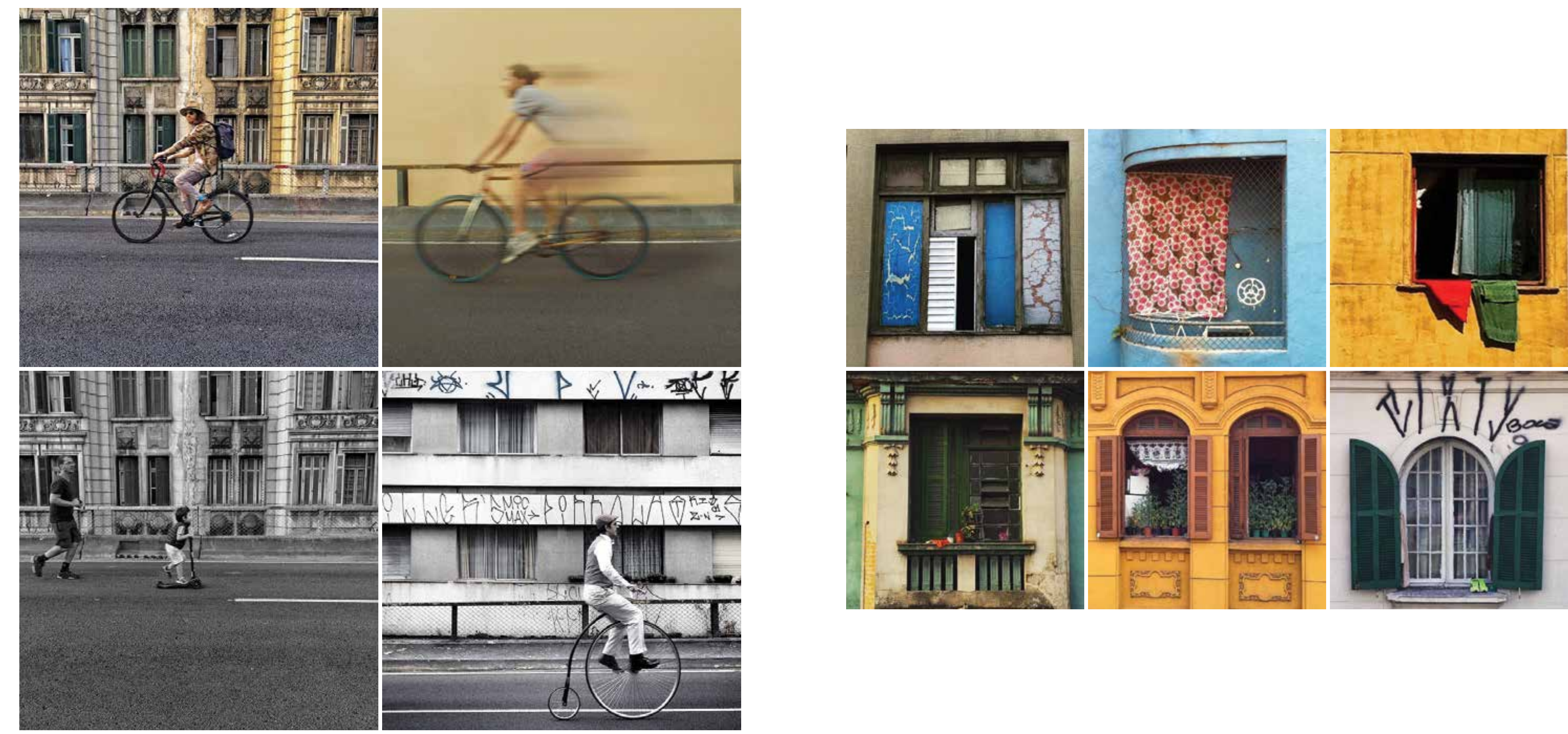

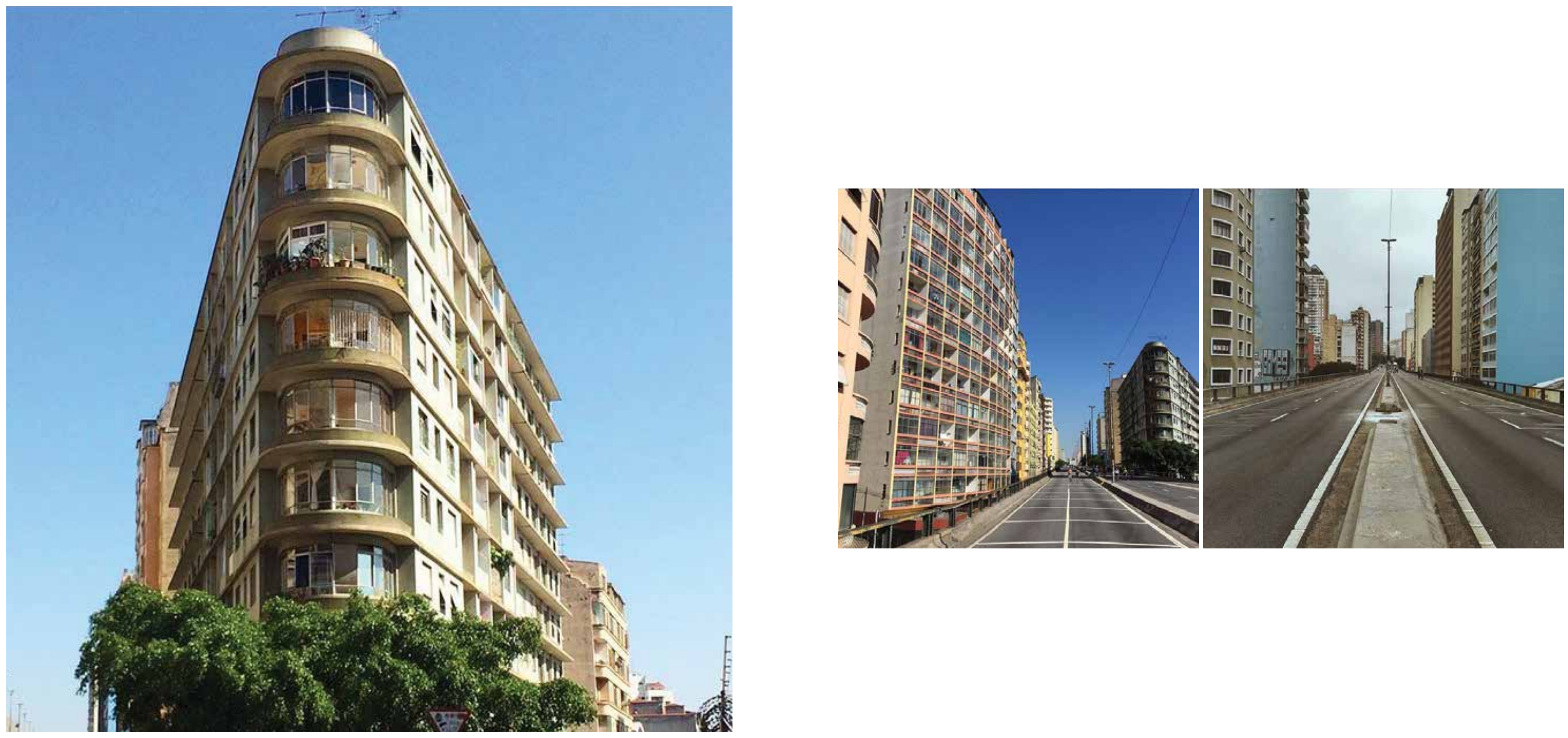

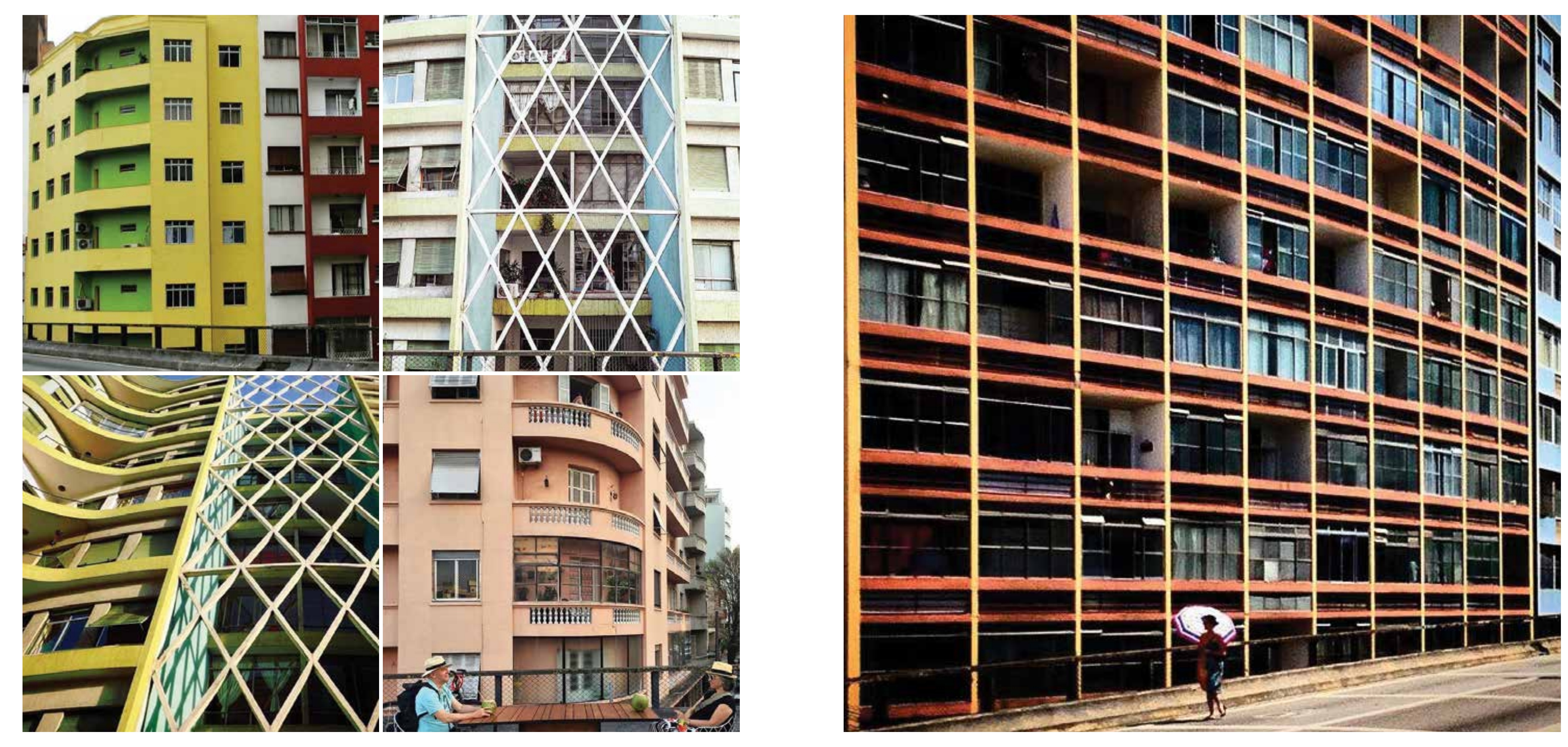

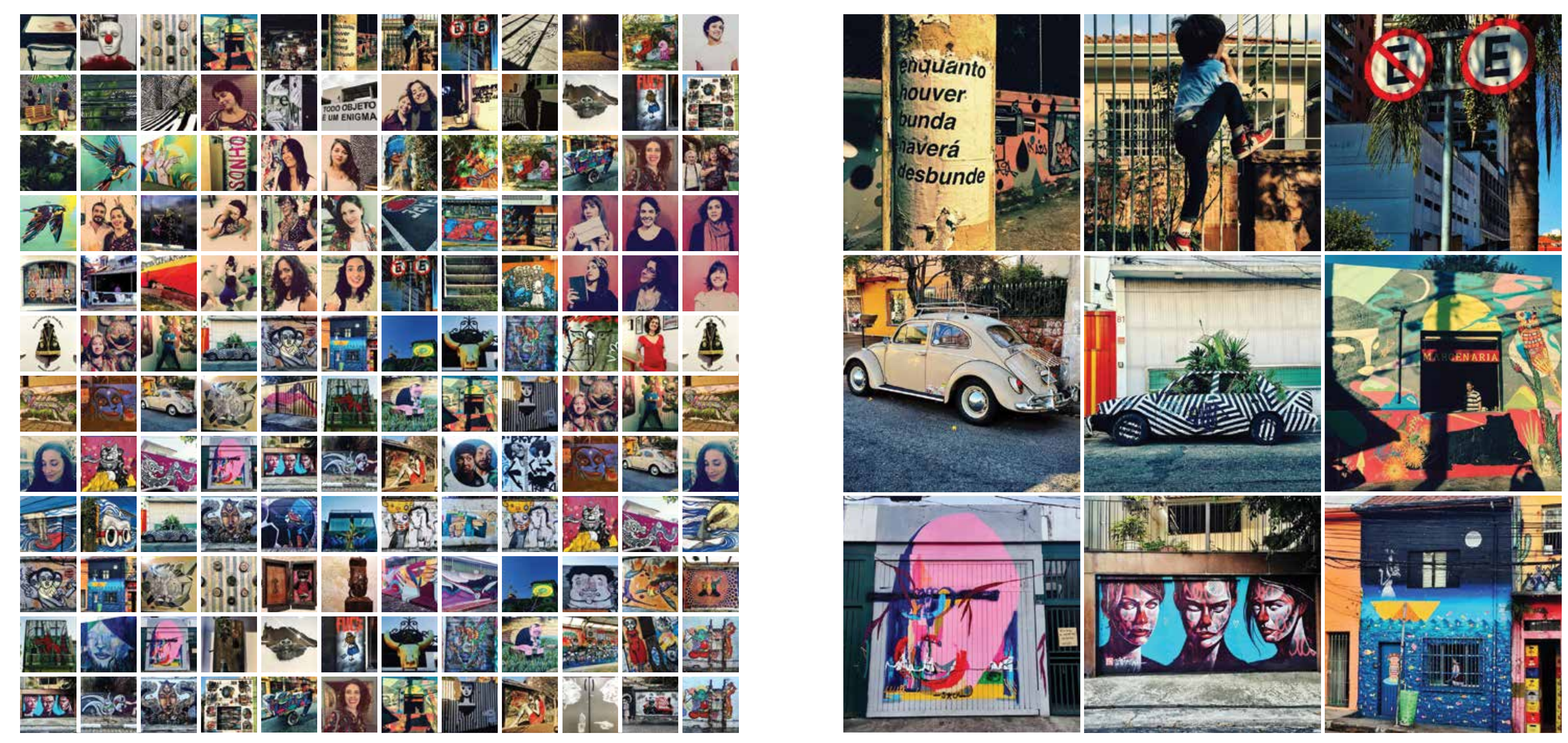

\#rolêvilamadalena 

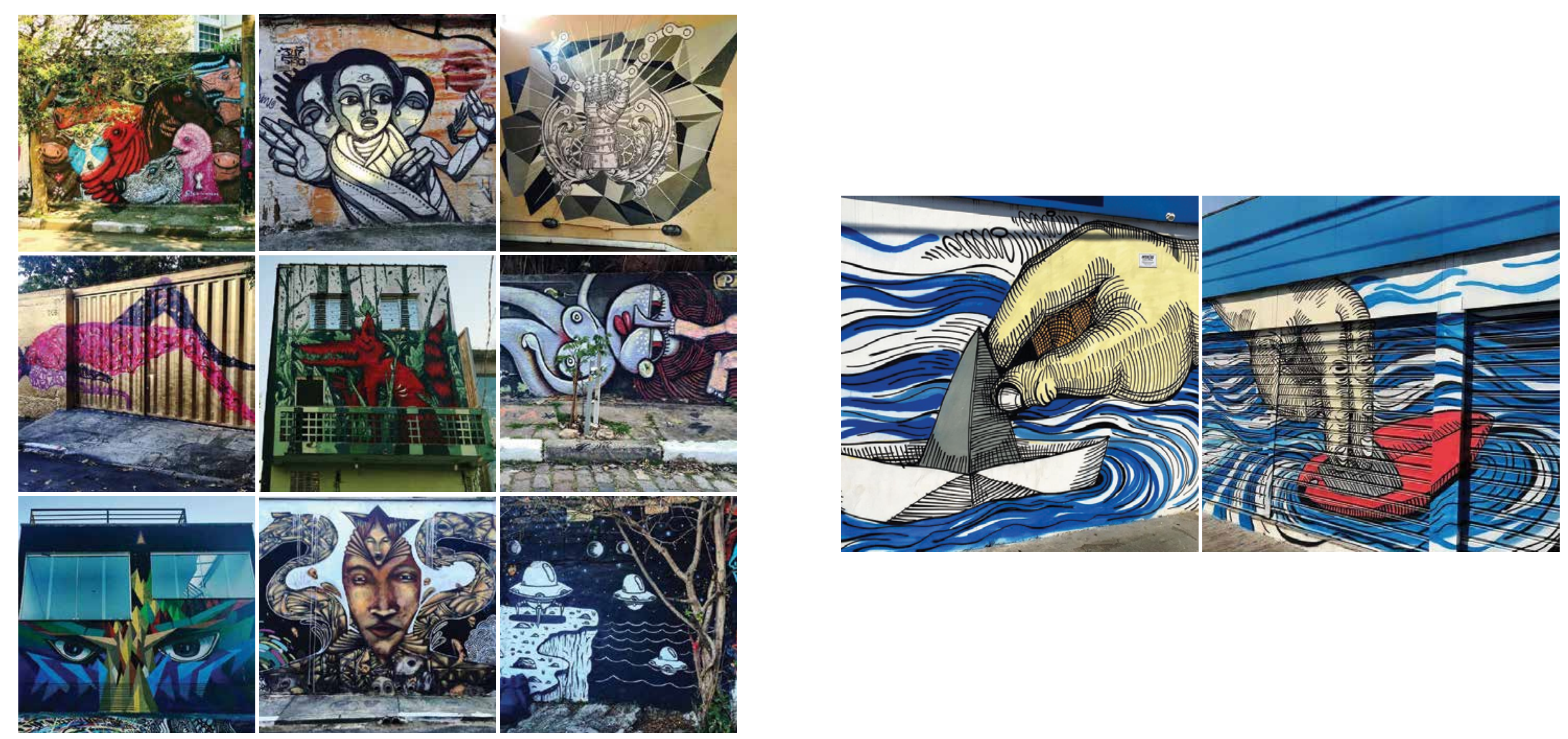

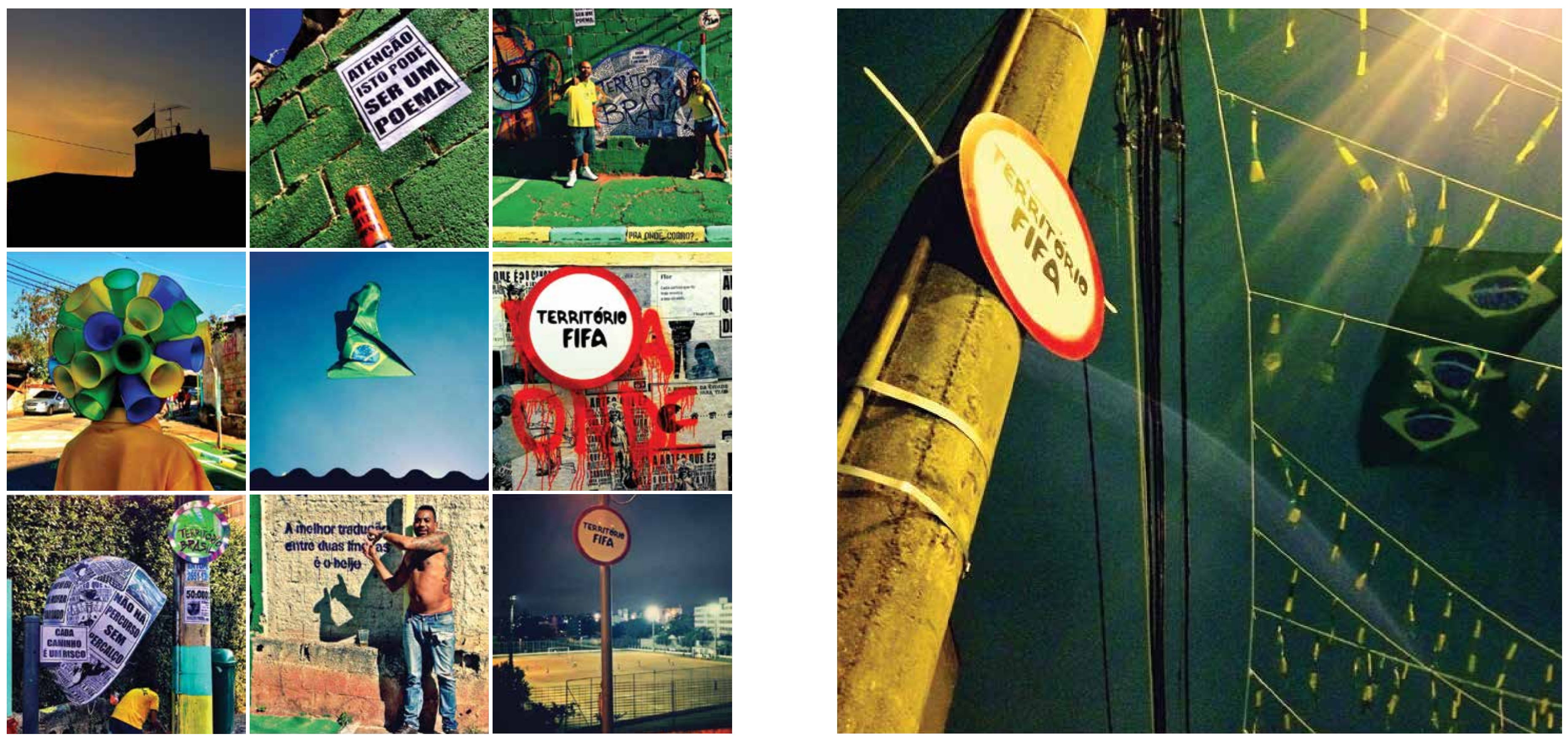

\#rolêltaquera

O ANDAR COMO PRÁTICA ESTÉTICA. Edição realizada a partir da \#rolêitaquera e pelo $\bullet$ Cohab Itaquera. 

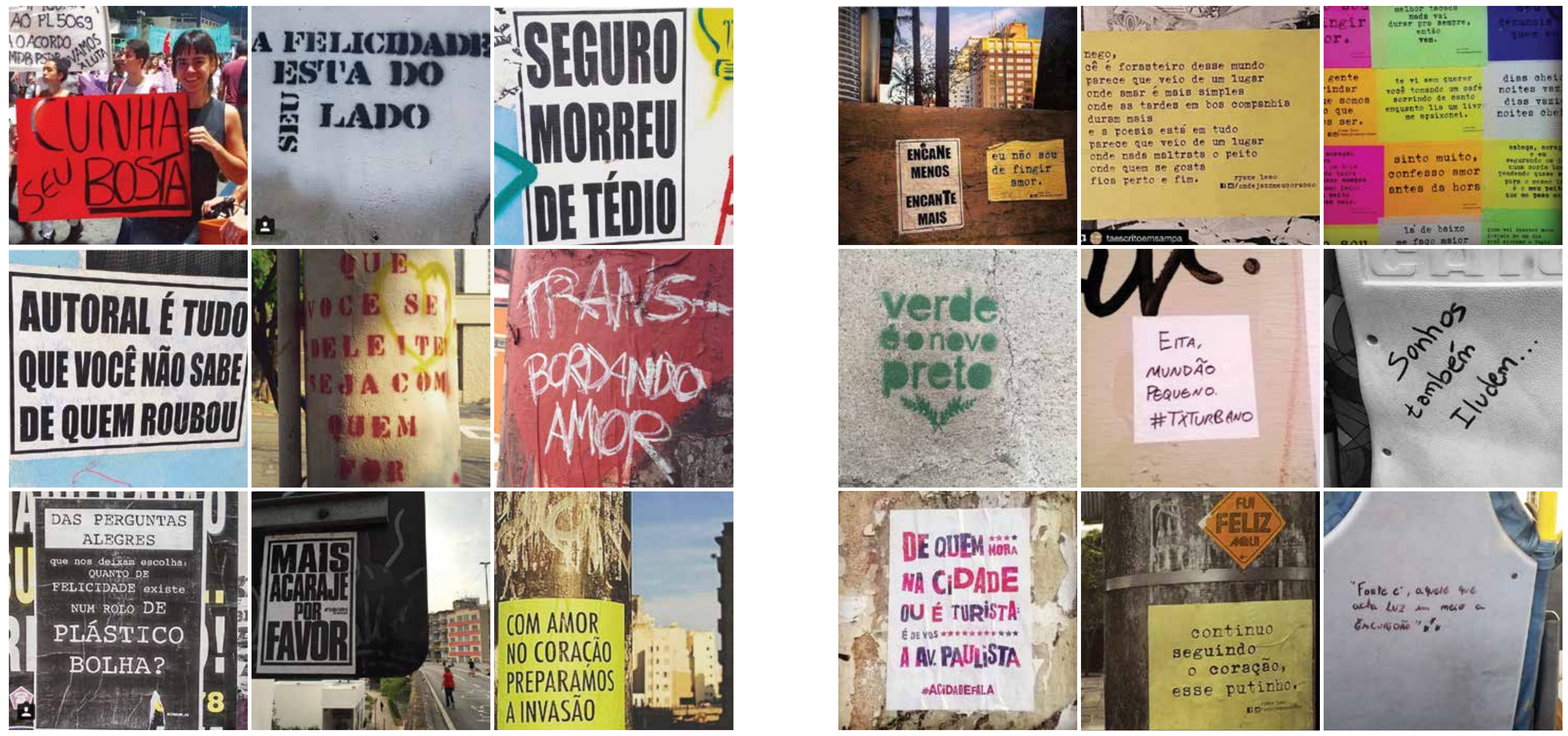

\#taescritoemsampa 

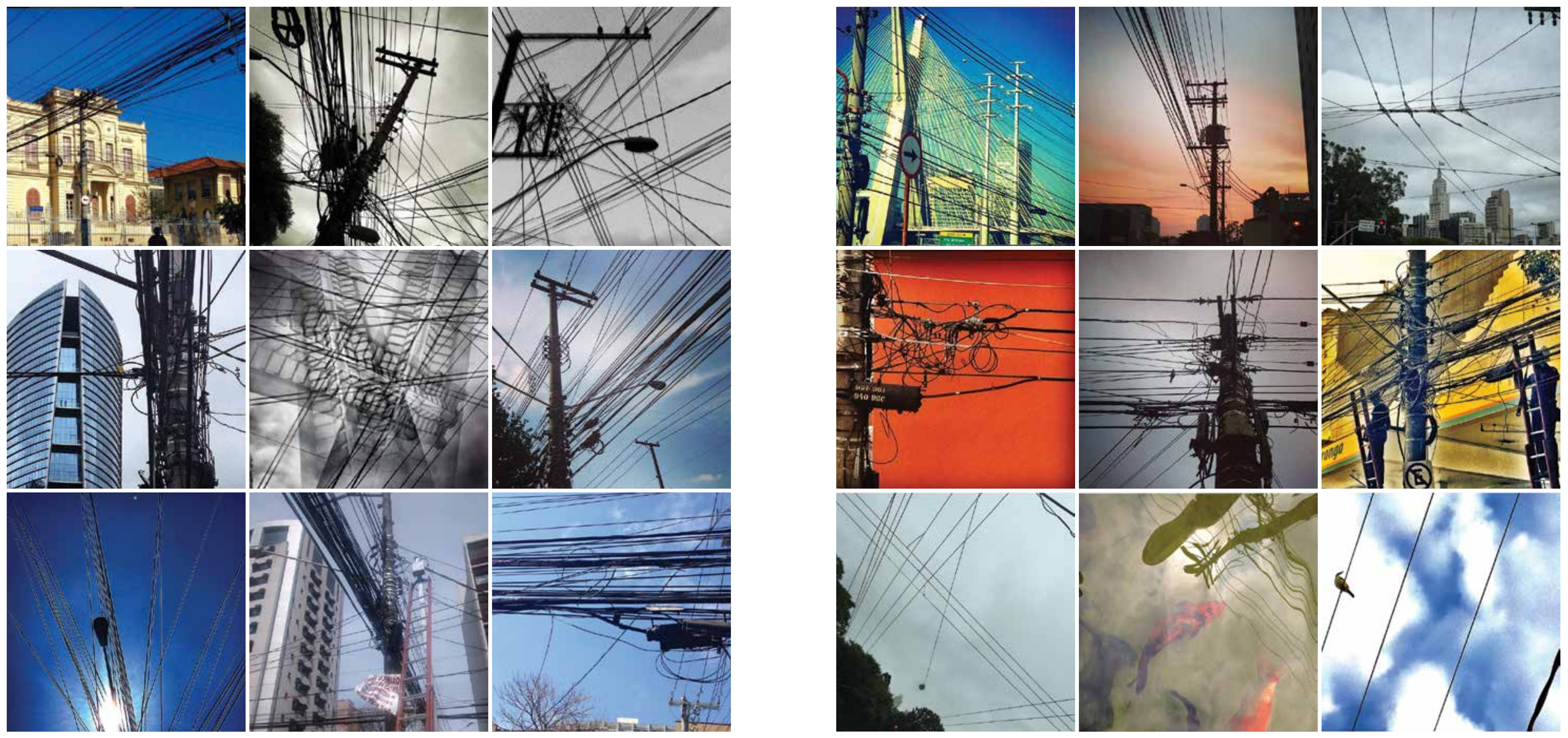

\#malditosfios

1494 posts em 10/11/2015 - Edição coletiva, idealizada e coordenada pelo jornalista Leão Serva E fica evidente a poluição visual causada pelos fios, elementos tão presentes na paisagem paulistana. 


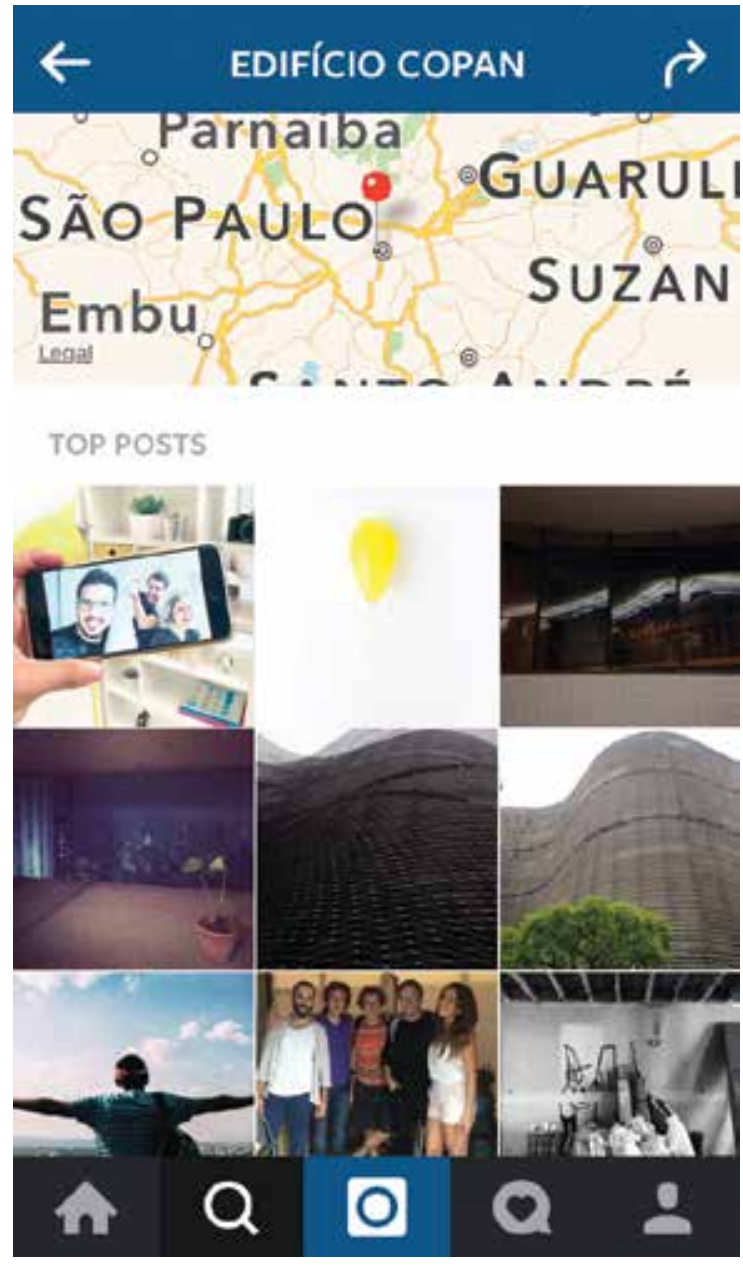

\section{P Edifício Copan}

47.369 posts (em 17/11/2015). Até essa data, o Edifício Copan era recorde de posts de um edifício de São Paulo no Instagram. Edição de imagem realizada a partir da busca pelo "lugar", e pelo $\bullet$ Copan. Por meio de fragmentos coletivos,
realizados por moradores e turistas, temos uma visão completa do exterior e do interior do edifício ícone de São Paulo. Acima, exemplo de desdobramentos de outras narrativas, geradas por novos tagueamentos, nas quais a mesma imagem estará presente.

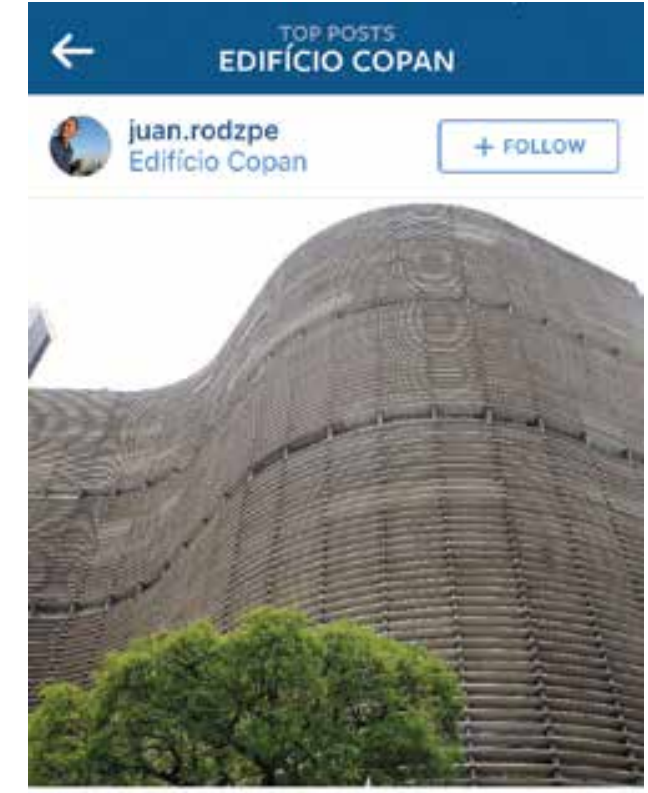

O

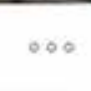

125 likes $12 \mathrm{~h}$

más importantes y emblemáticos edificios

piscos, 5000 habitantes, 1170
pis

departamentos, 72 tiendas y una iglesia

evangetica. La construccion está

de hormigón

dificio Residencial en Amêrica.

\#saopaulo \#săopaulo \#brasil \#brazil

\#igerssaopaulo \# Hrasilien \# \#saopaulocity
\#igersbrazil \#fig saopaulo \#copan \#buildings

Hedificio \#architecture \#ig_brazil _.

\#travellers \#edificiocopan \#saopaulowalk

\#architectureporn \#mytravelgram

\#traveladdict

hstabile wow this is beautifu

\& $\mathrm{Q} \quad \mathrm{O} \quad \mathrm{Q}$ de la ciudad de Sao Paulo, Brasili. Es un

\#picoftheday \#trip ttravel Htraveler
\#n

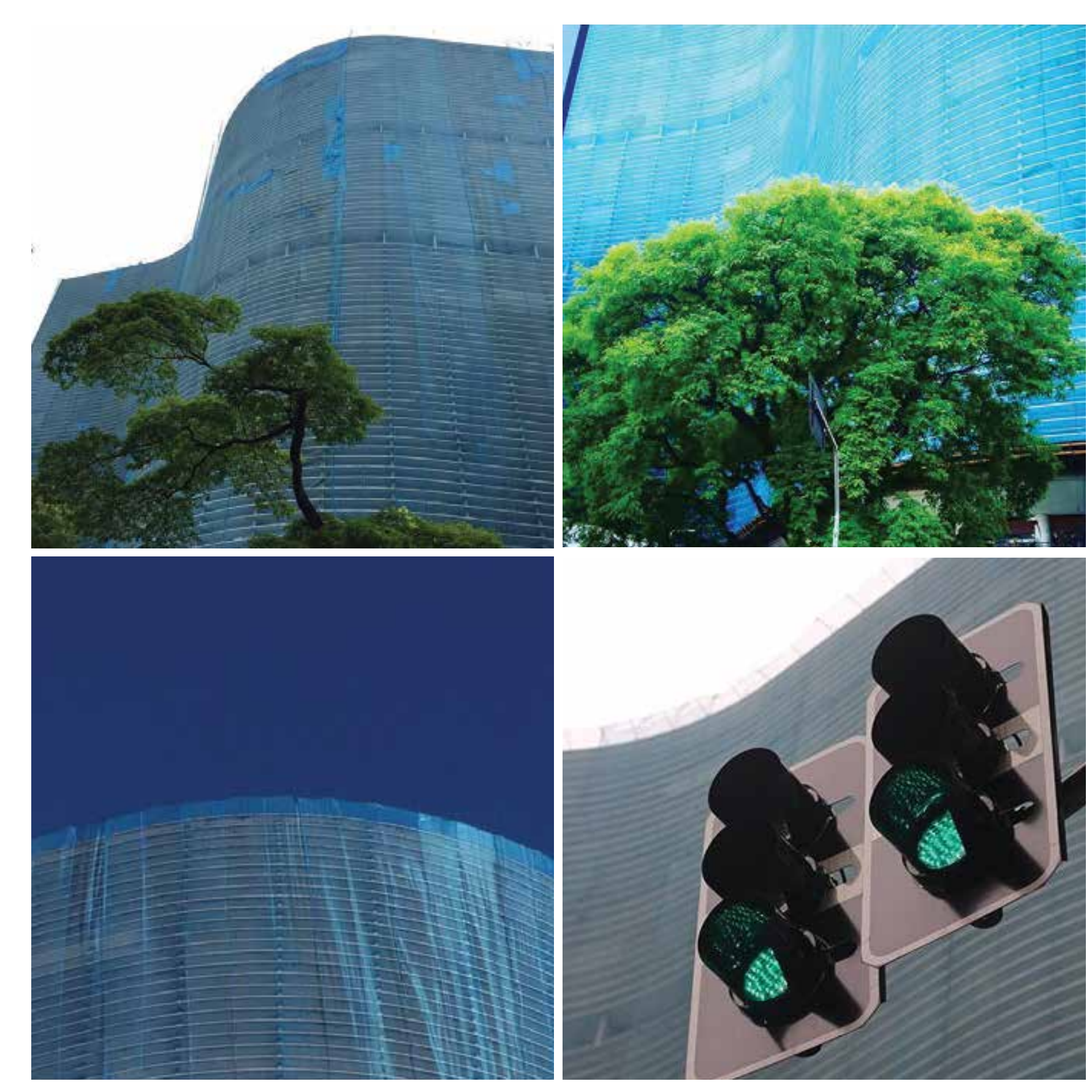



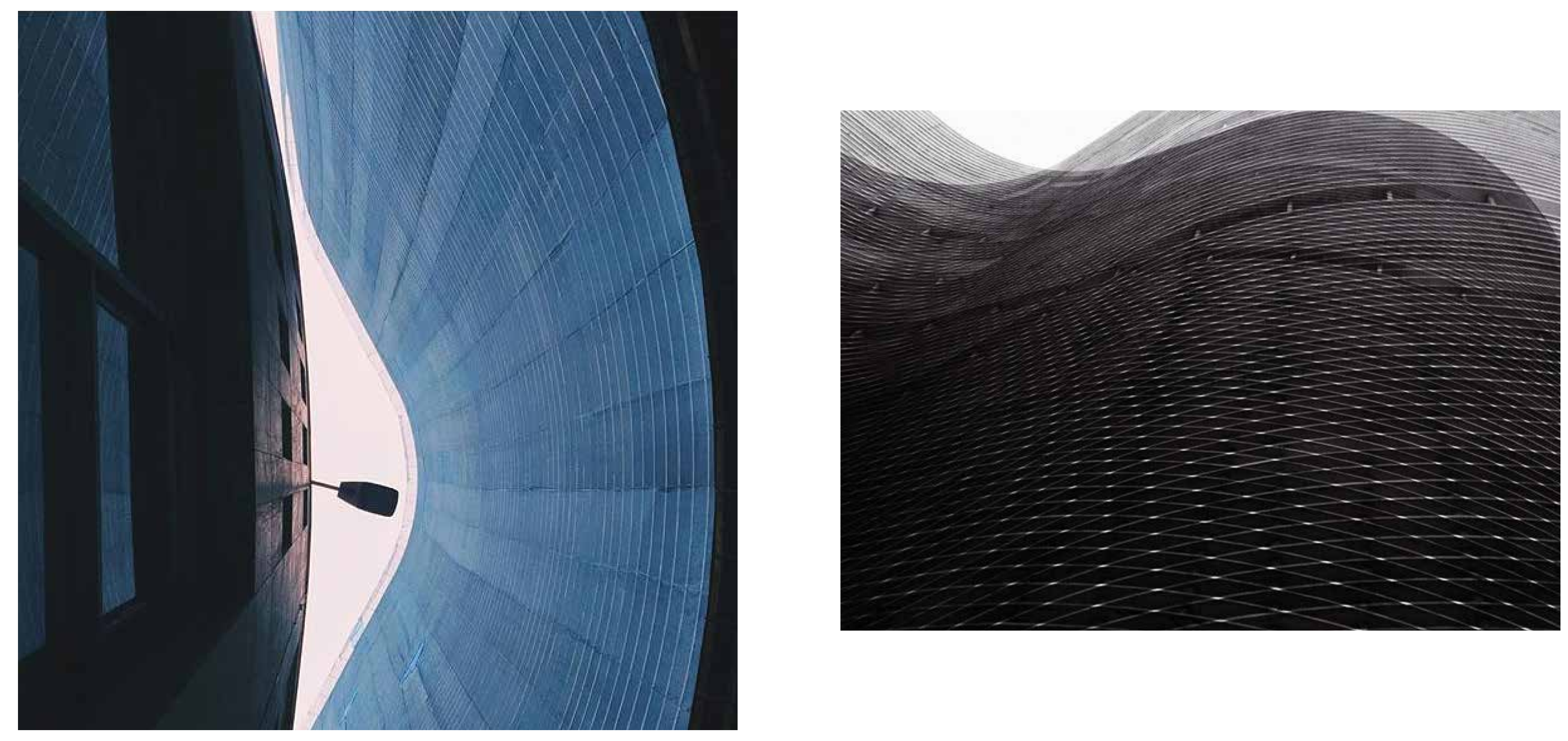

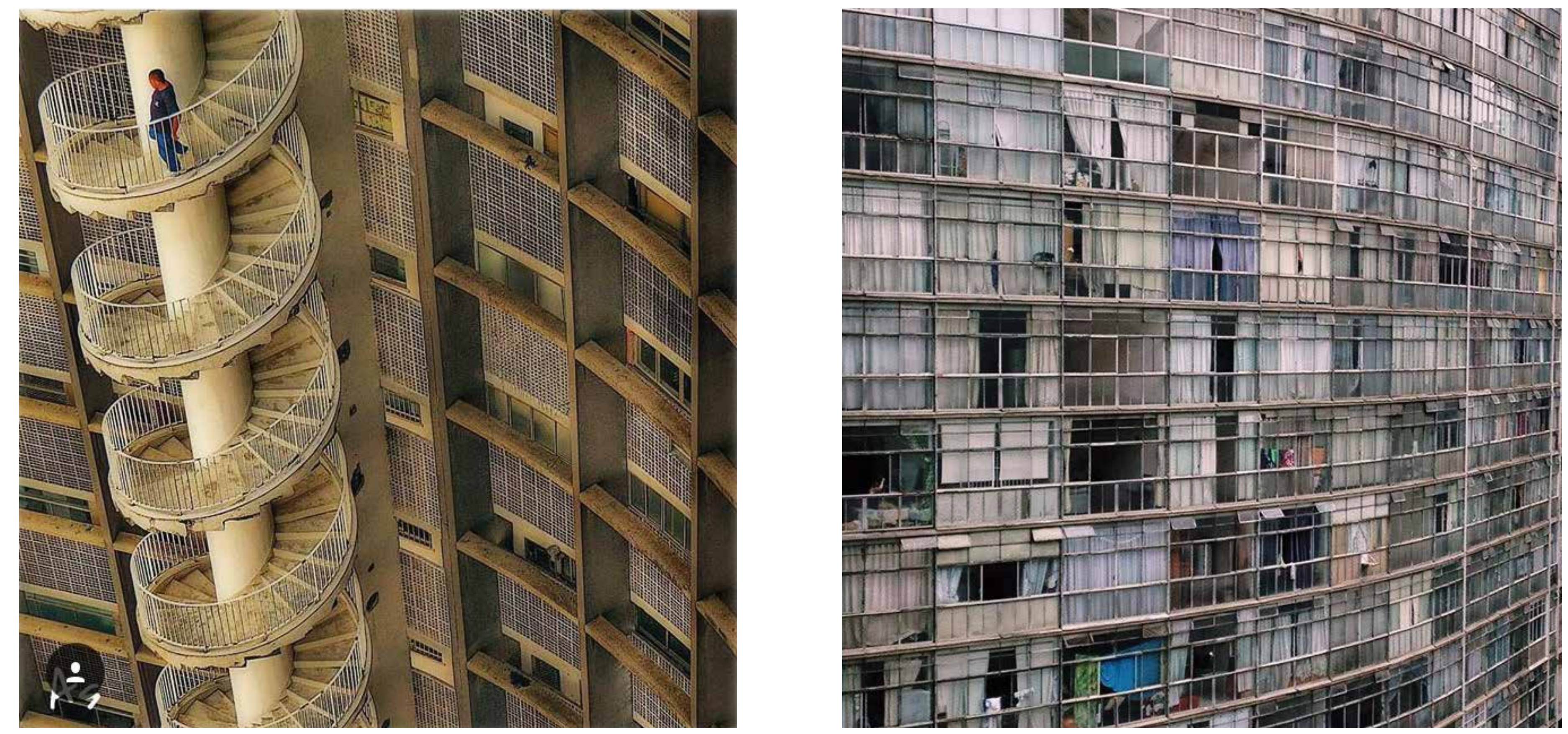

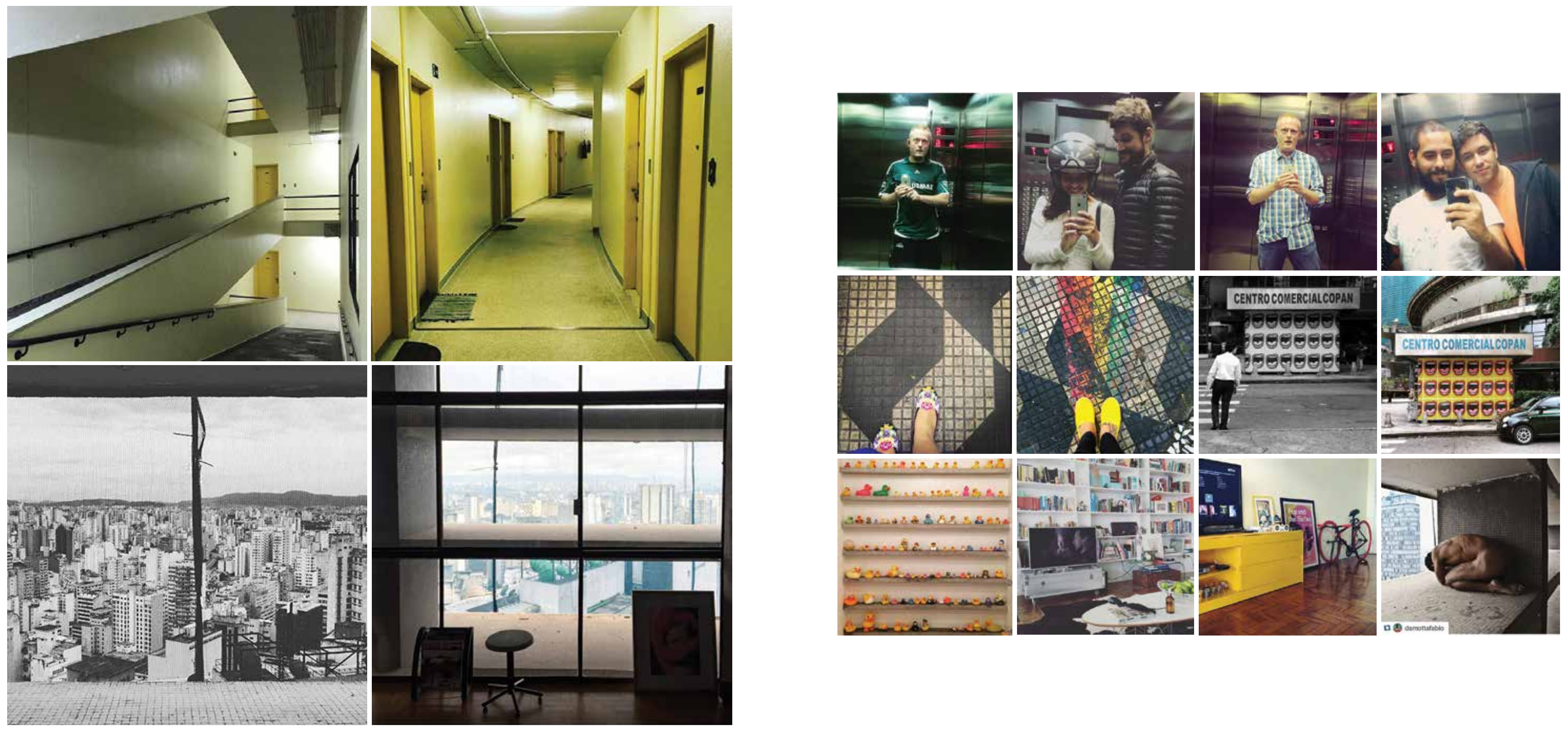


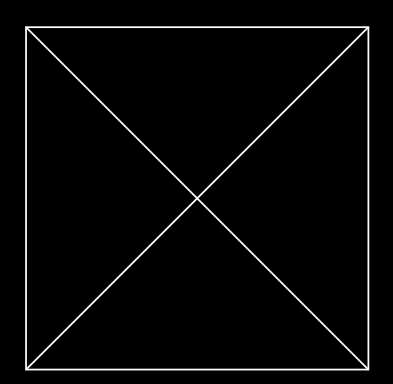

Percepção e subjetivação do lugar

Singularidade poética na representação da paisagem

Edições de ensaios realizados a partir da pesquisa das

postagens de alguns autores cujo trabalho foi acompanhado

durante o período de aproximadamente dois anos (2014 a

2016). São edições apropriadas pela autora desta imageria.

Muitas dessas imagens estão completamente soltas, ou perdidas na rede pois não estão indexadas com nenhum \#

ou $\boldsymbol{\bullet}$, só sendo possível encontrá-las pelo nome do autor

- imagens isoladas, postadas em diferentes dias e locais,

durante operíodo de 2 anos de publicação no Instagram. 

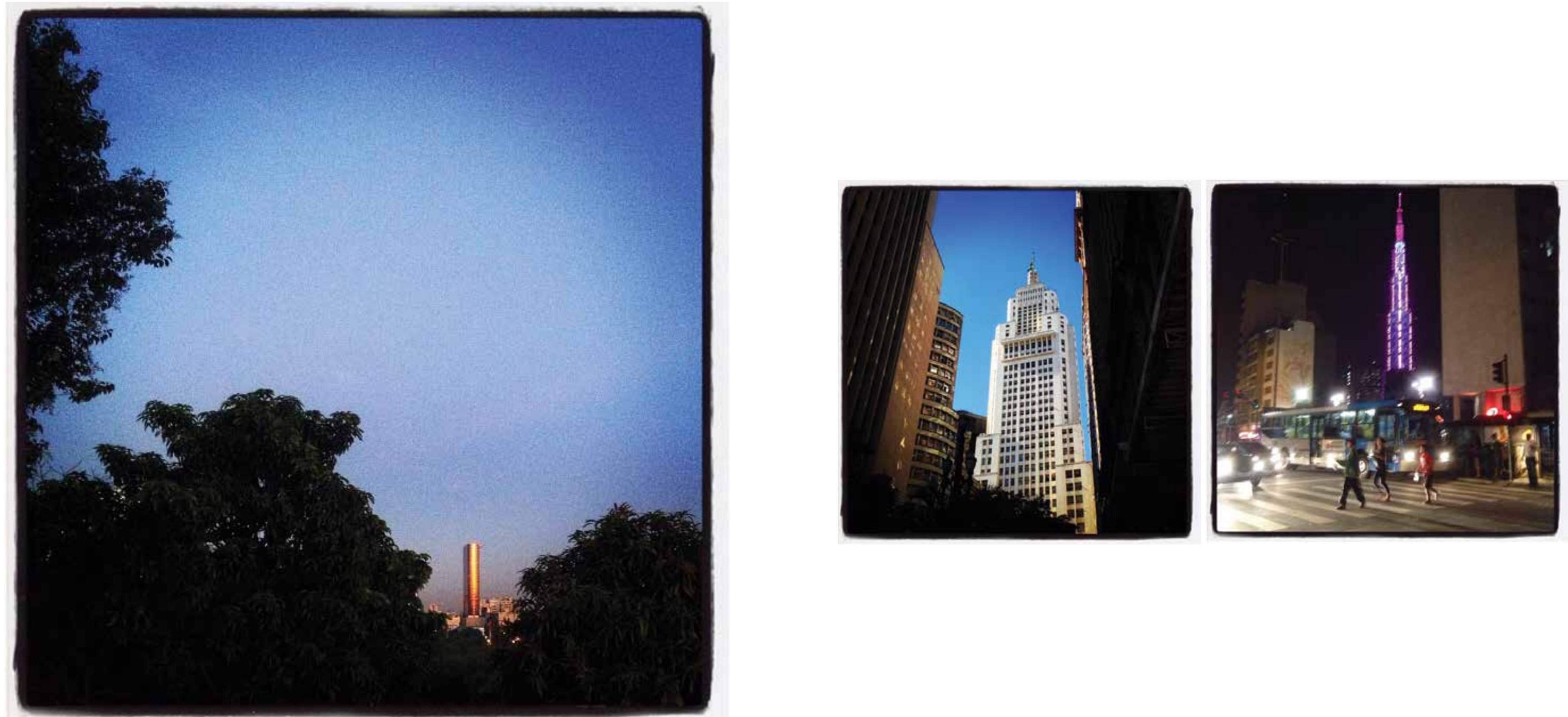

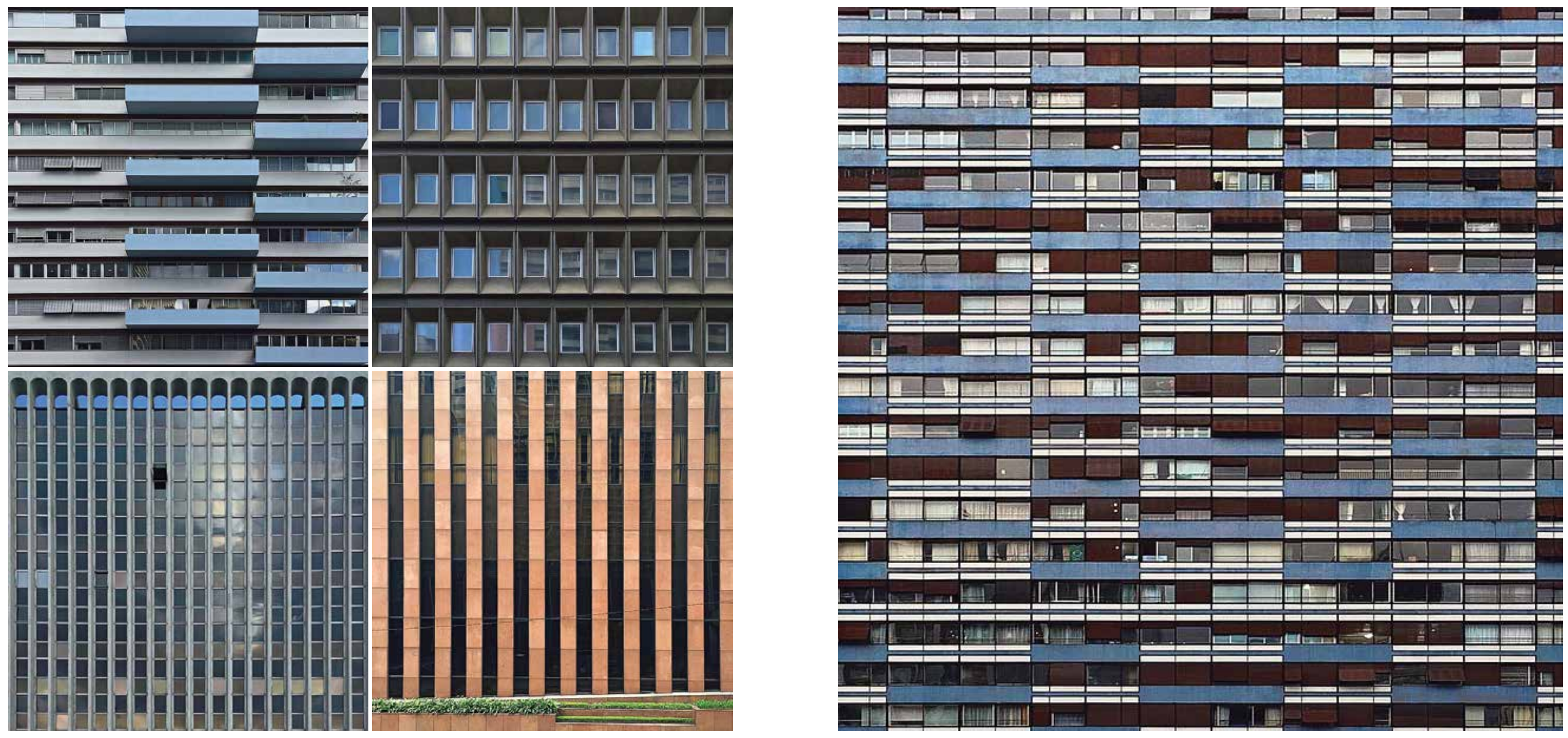

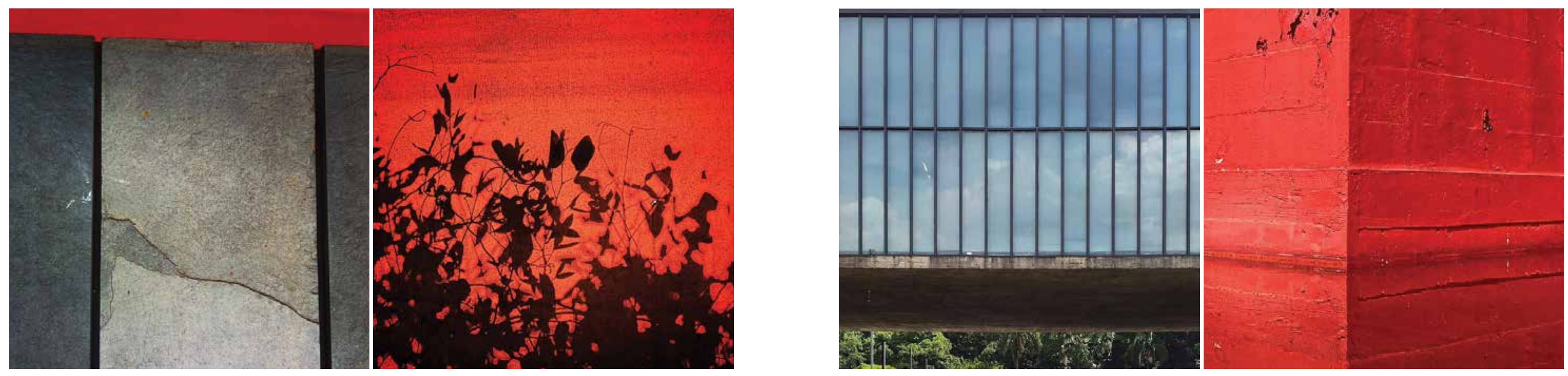

ENSAIOS. Edições realizadas a partir da busca pela palavra-chave MASP, pelo $\bullet$ geolocalizador e pelo cruzamento com o nome dos fotógrafos Miriam Homem de Mello e Danny Zappa. Imagens postadas em datas distintas. 

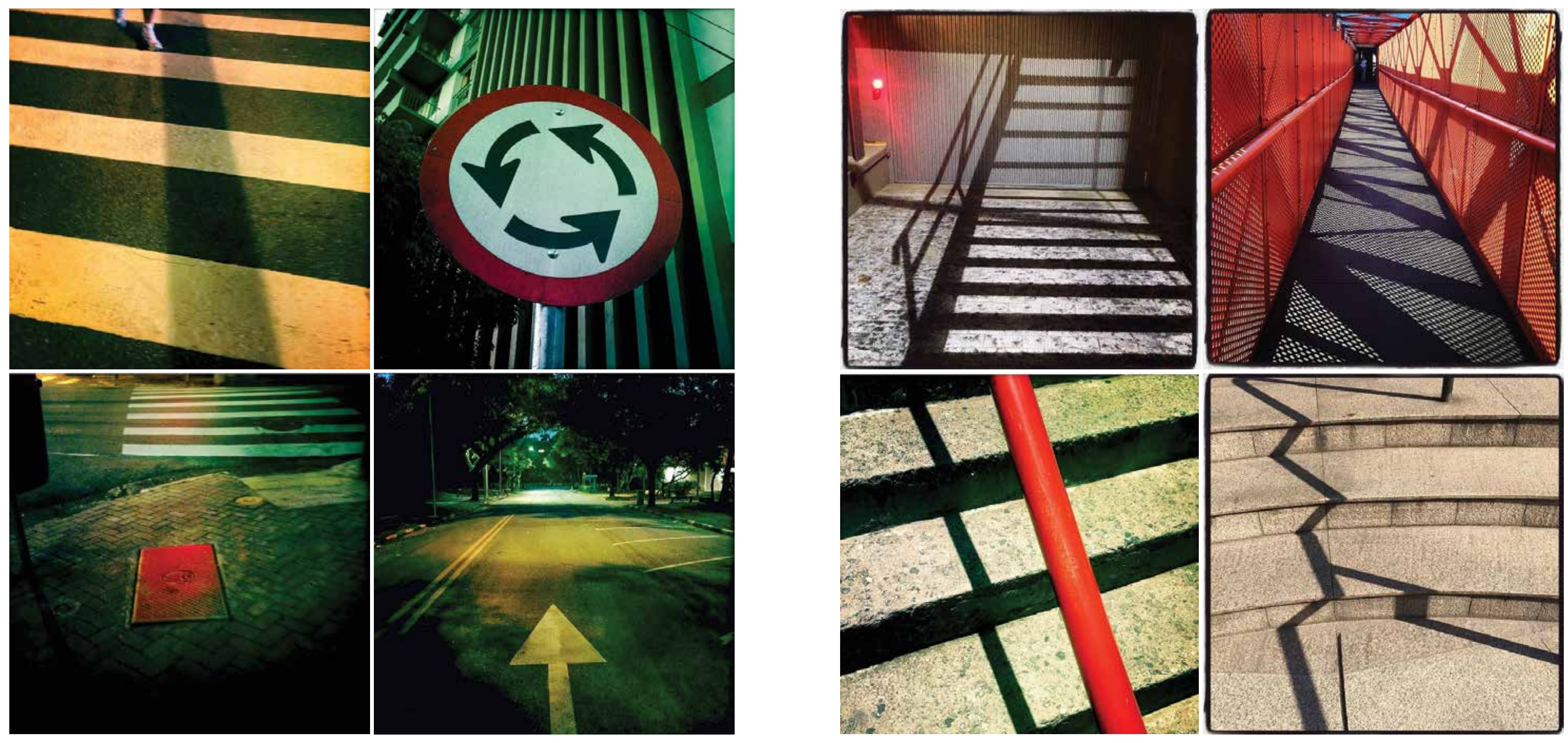

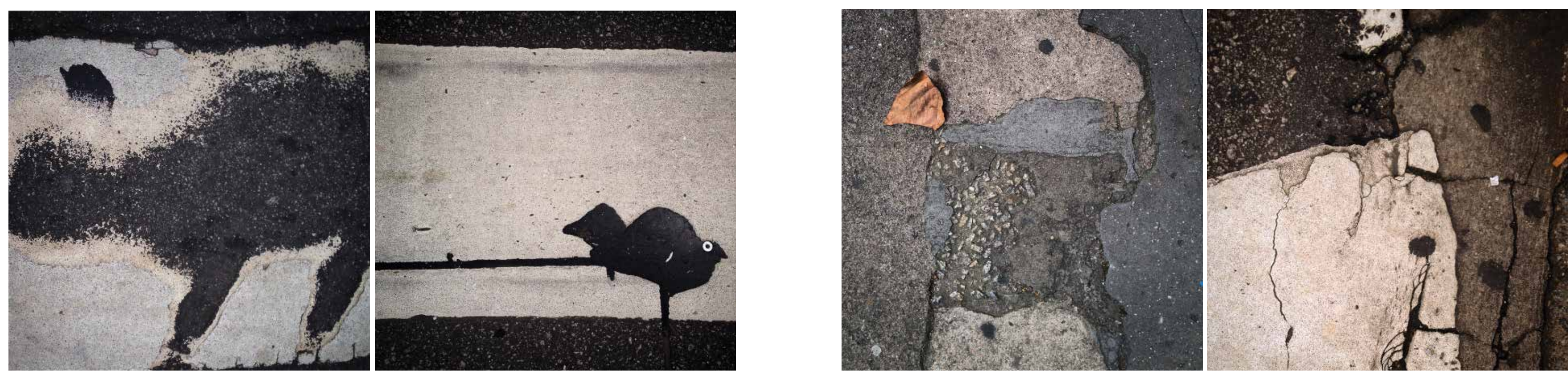

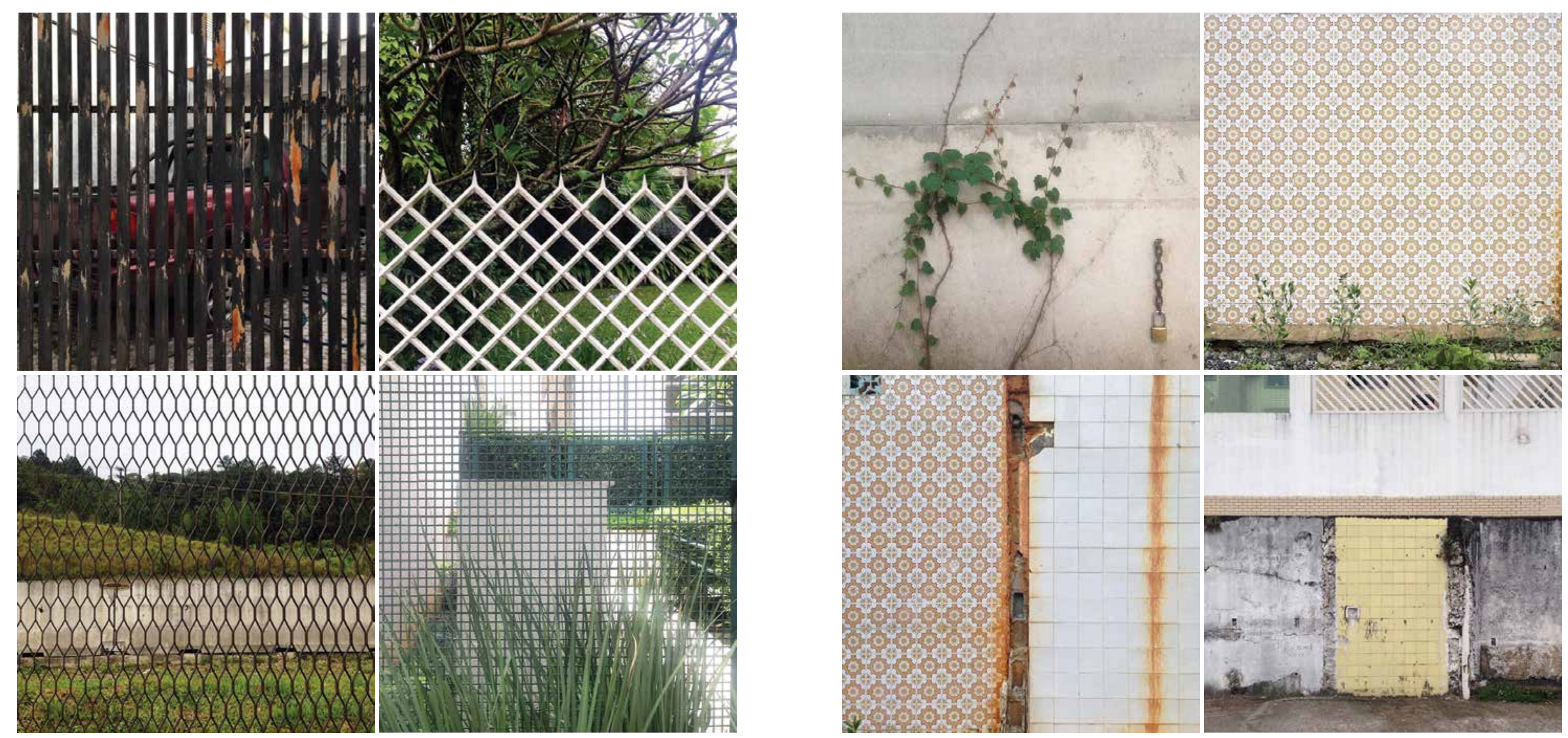

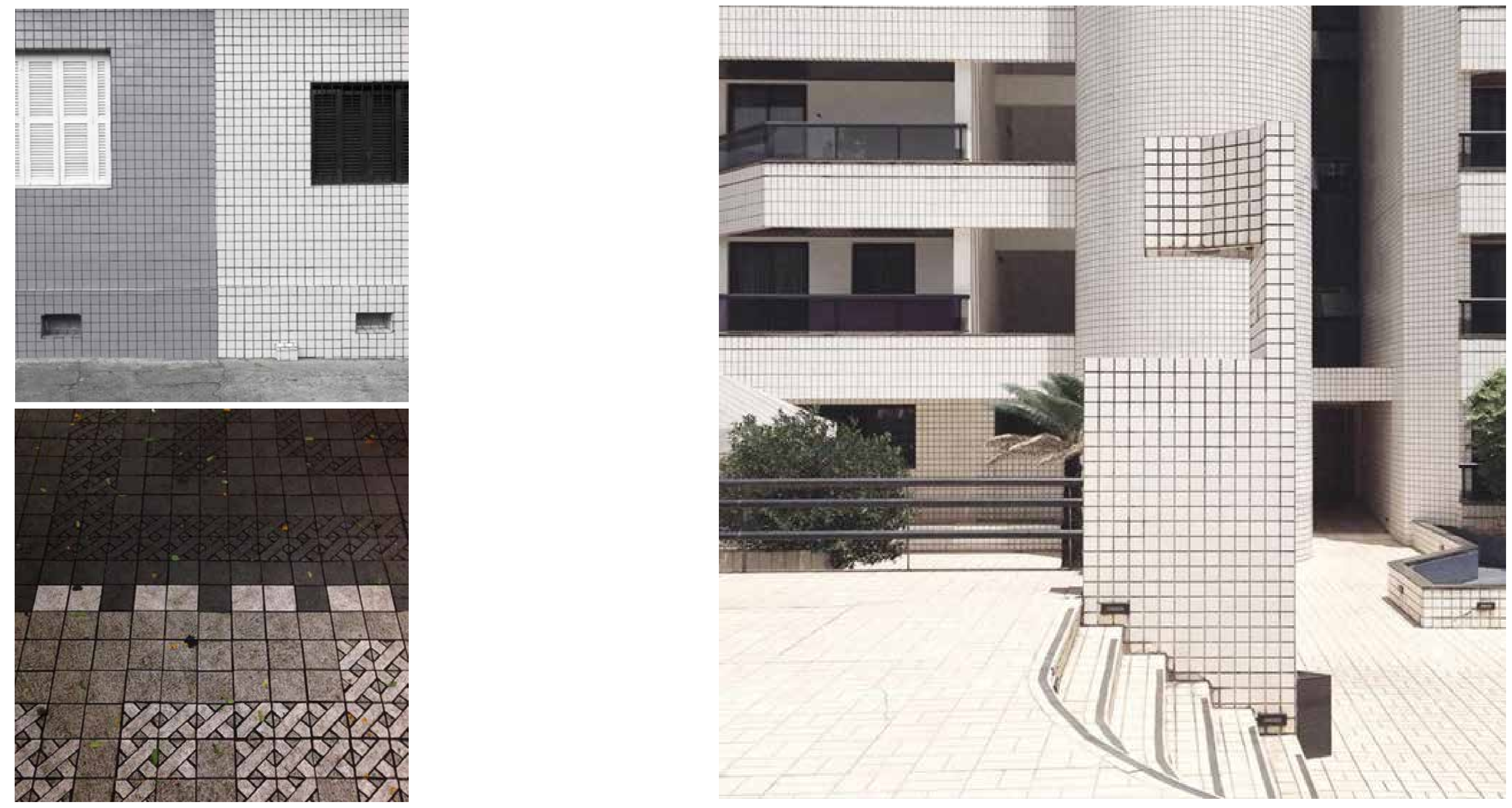


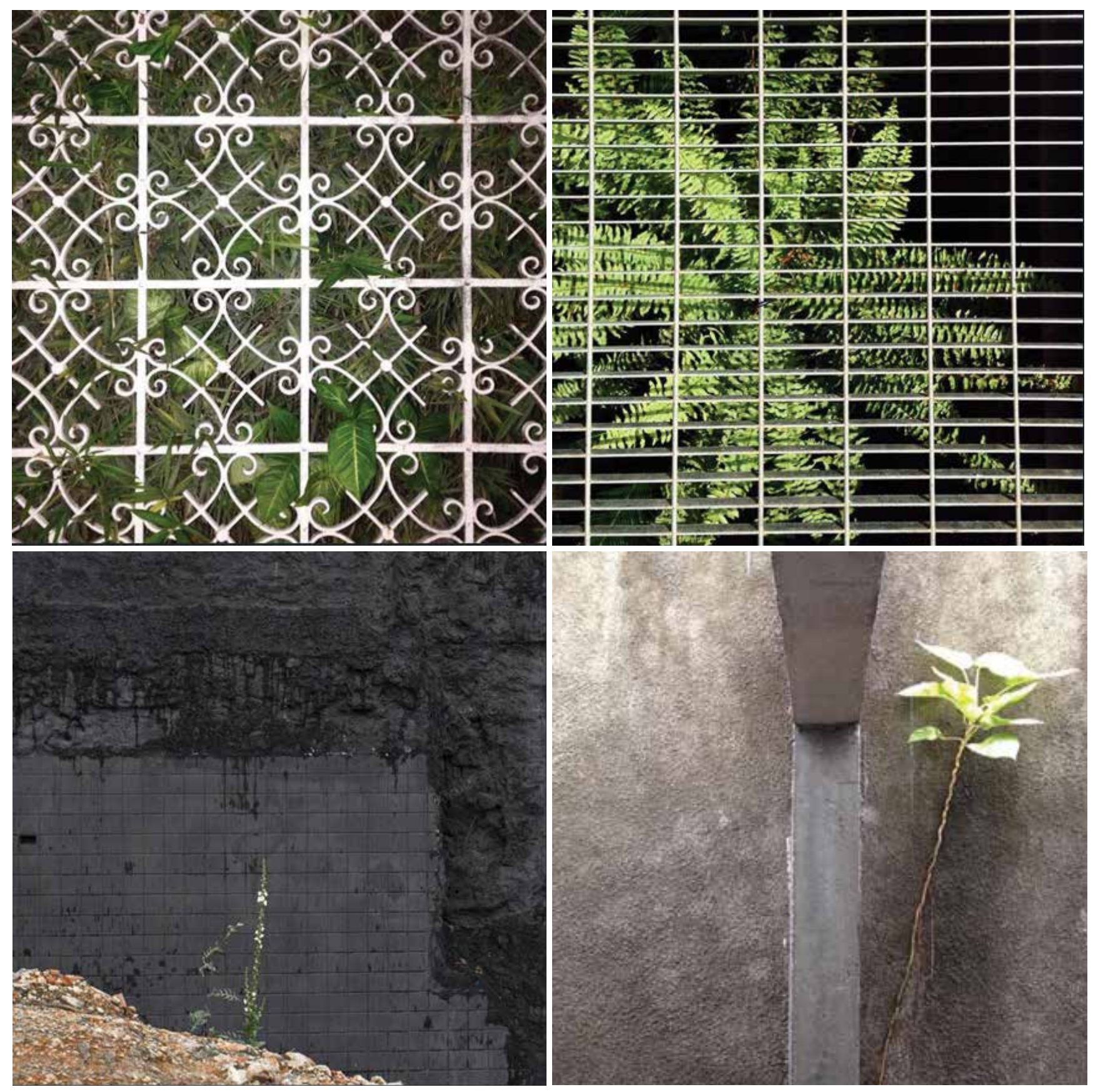

AYETEN क(O) G. (O) हn

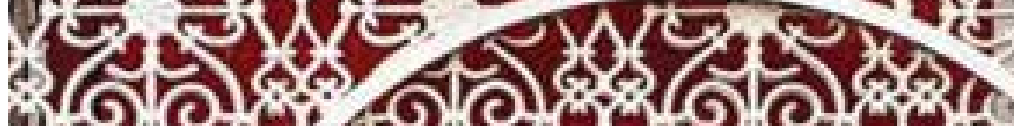

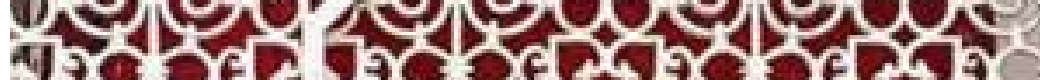

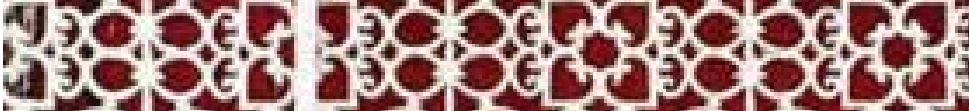
૧.

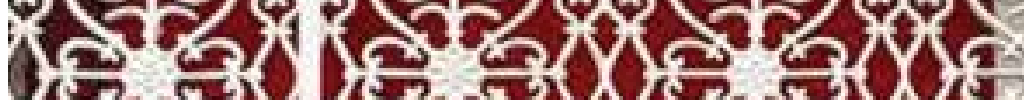

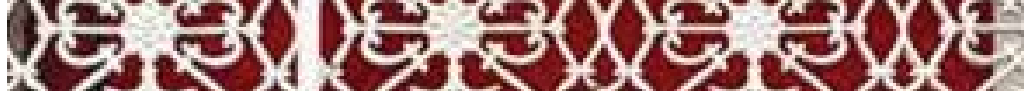

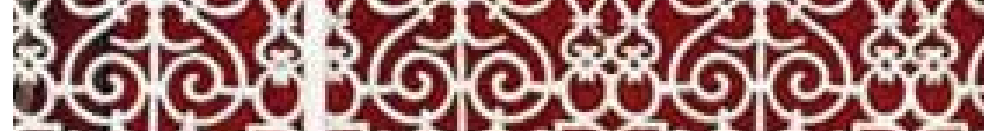

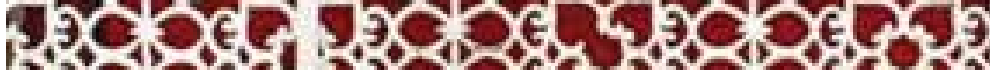

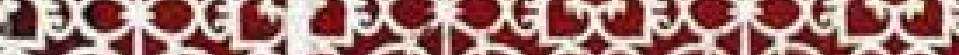

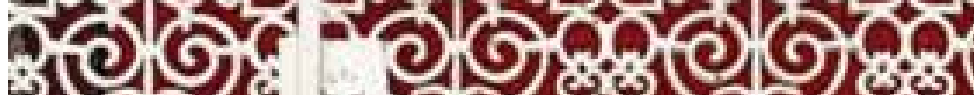

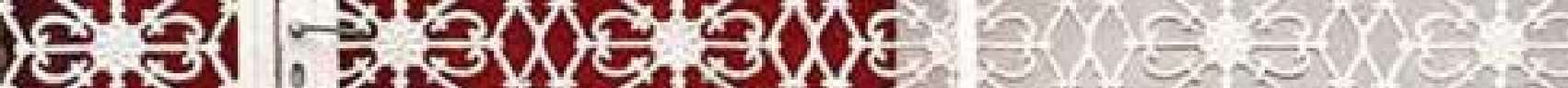

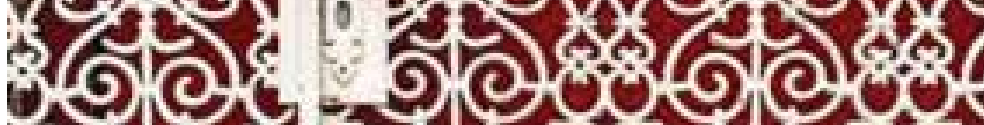

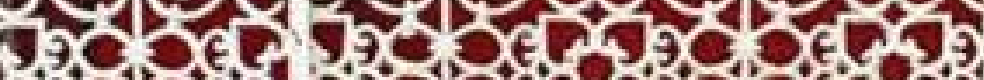

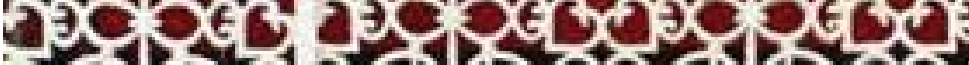

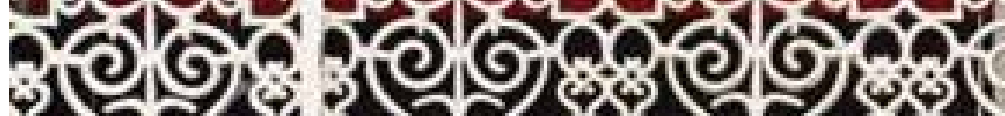
皮 $=2 x$

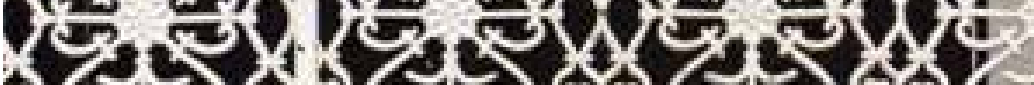
\%)(อ) Y.

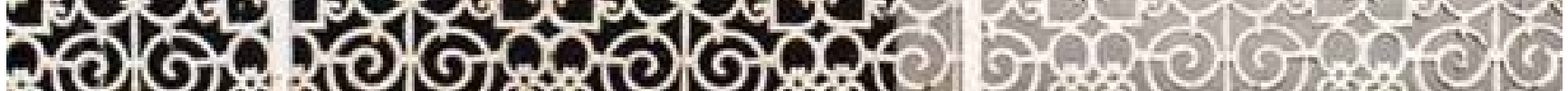




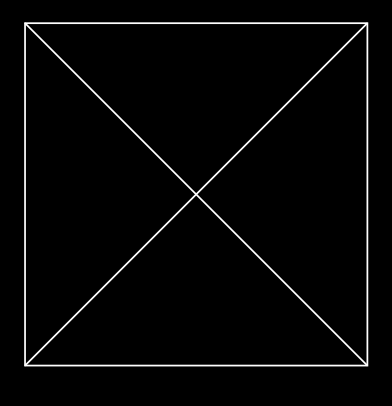

In

$\# \mathbf{X}$

O uso do algoritmo como estratégia artística 

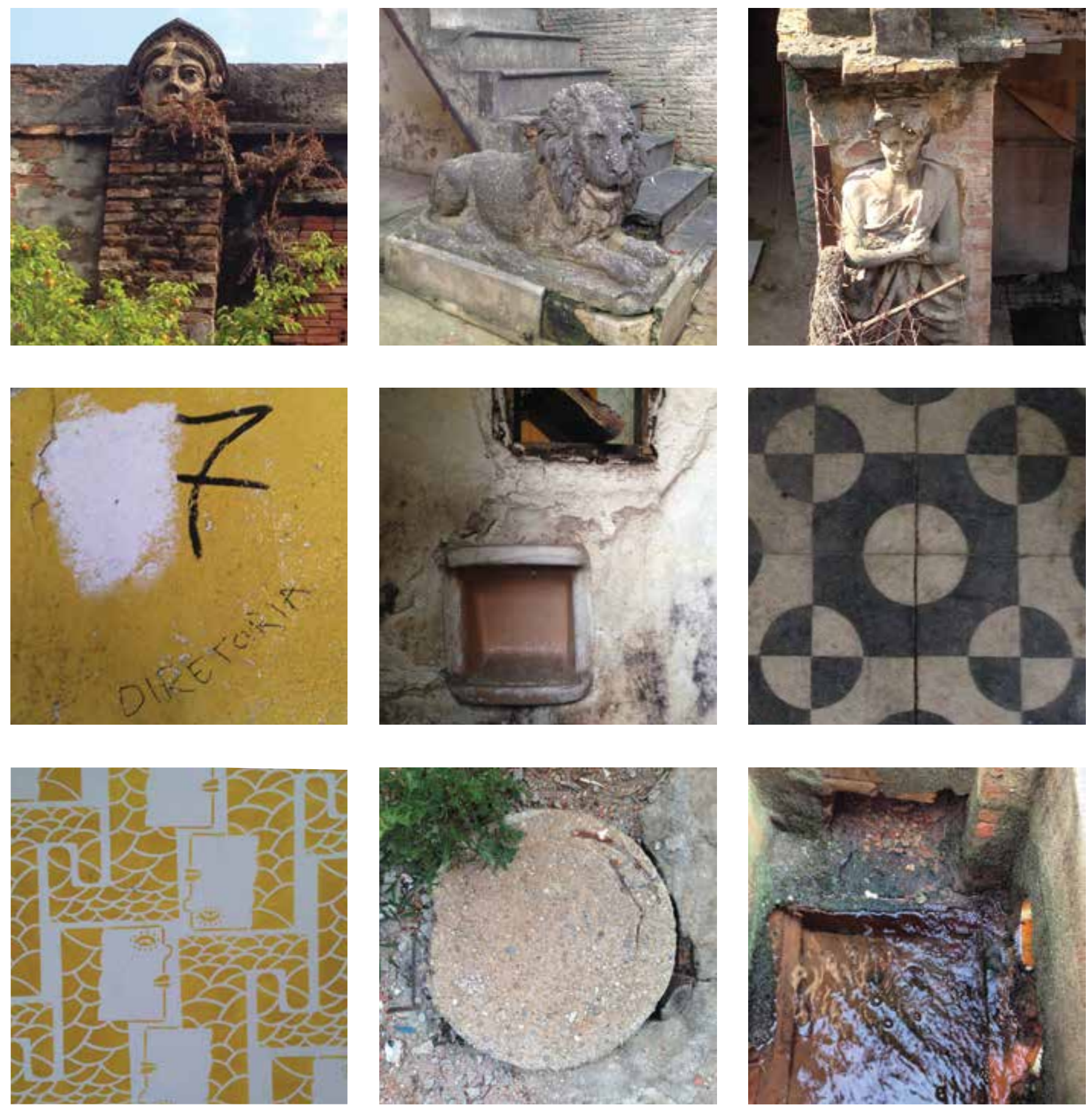
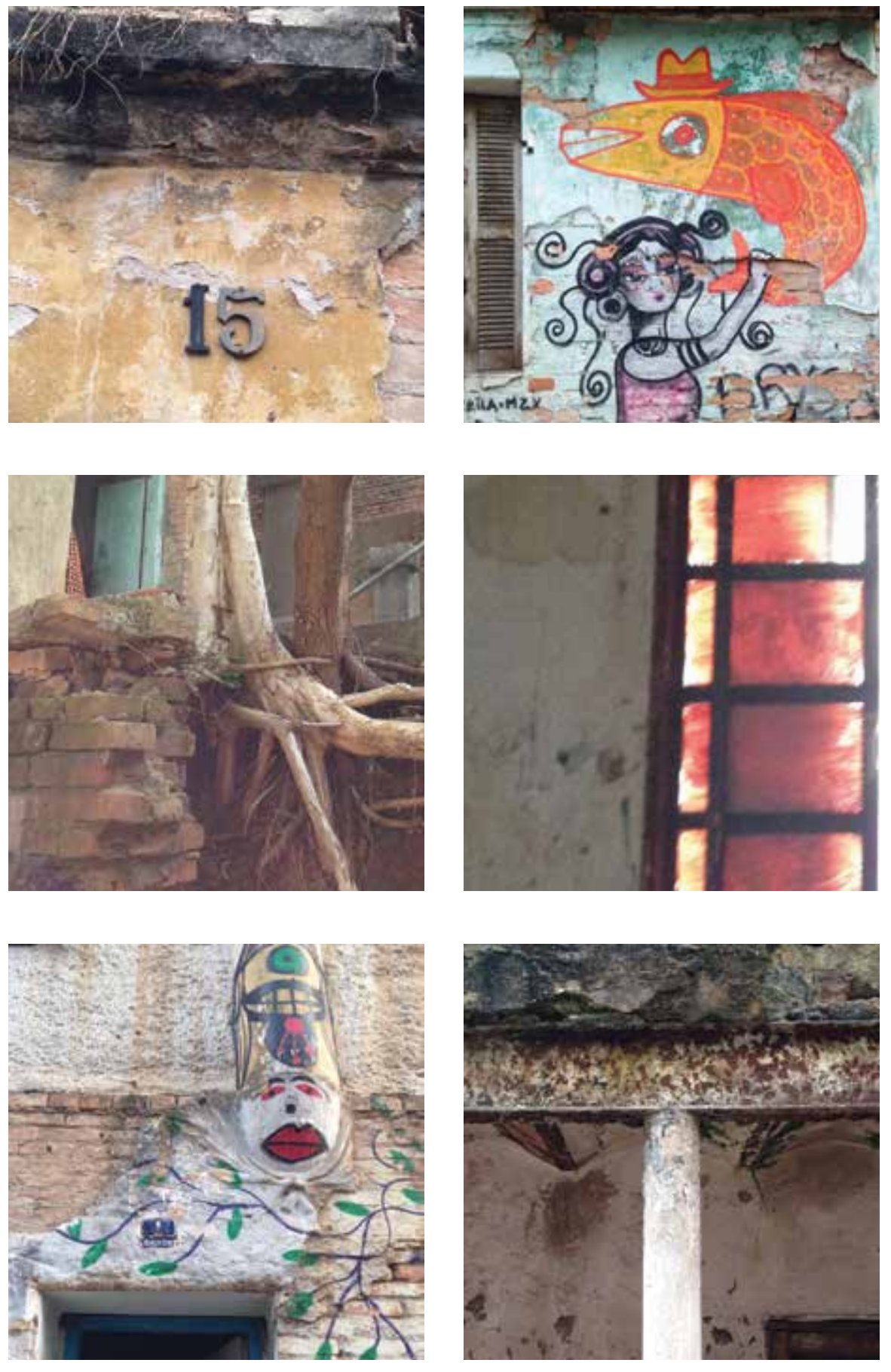

\#melvitororo (2015)

Jogo de memória

Ensaio realizado na Vila Itororó, proposto como parte da investigação desta dissertação aos alunos da disciplina

Lugares de Memória e Consciência: teoria e Intervenção, ministrada pelo prof. Renato Cymbalista.

Os participantes usaram suas câmeras celulares para registrar várias camadas narrativas (eixos temáticos) que representassem

as questões envolvidas com o restauro e novos usos da Vila Itororó: \#melvitororo, \#melvimorar, \#melvilazer, \#melvicultura,

\#melviagua, \#melviagriculturaurbana, \#melvilazer. Editamos as imagens publicadas no Instagram e no Facebook e construímos
um protótipo de jogo de memória, um objeto lúdico e estratégico para sensibilizar os visitantes, sobretudo crianças e jovens, durante a visita guiada ao Canteiro Vila Itororó. 

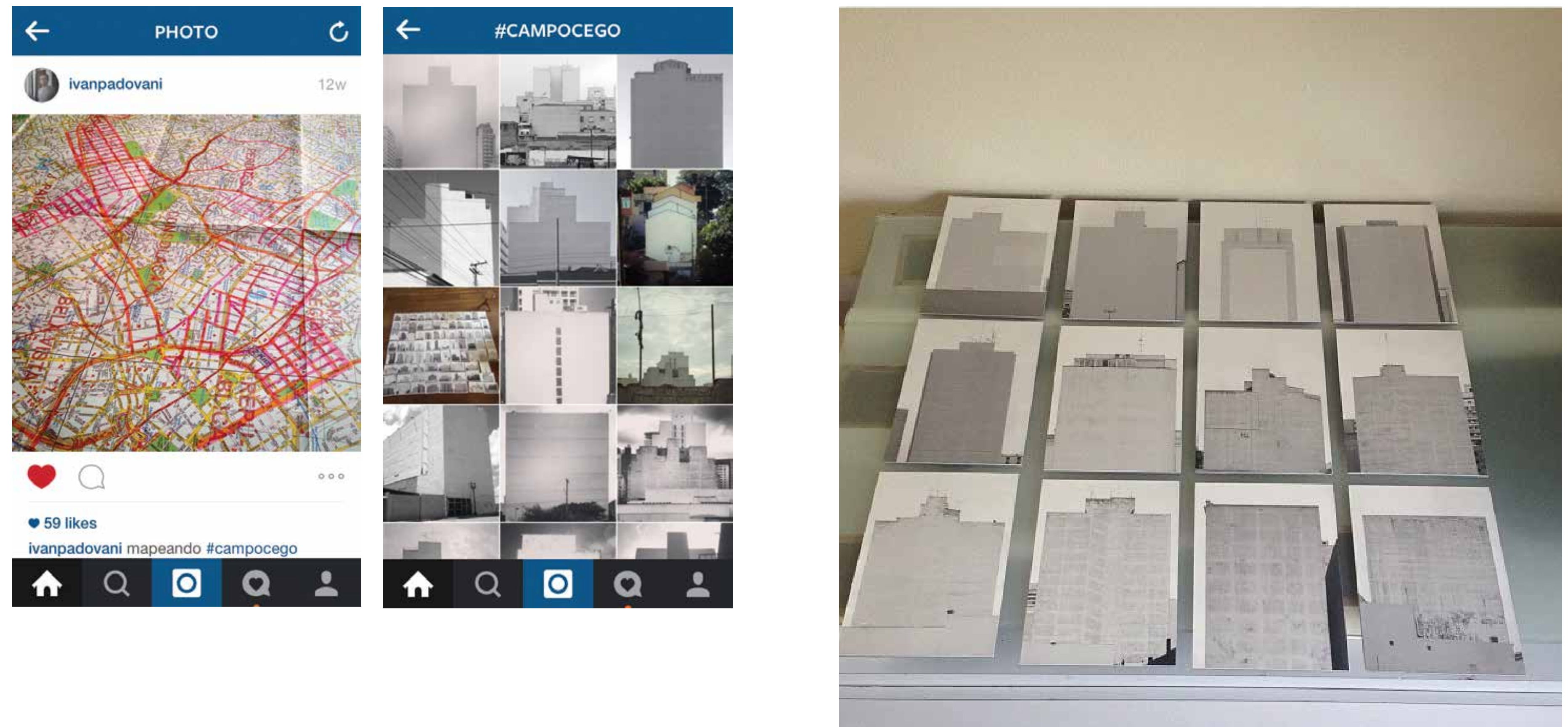

\#campocego (2015)

to das empenas de São Paulo. Esses monolitos brancos passam a ser os marcos referenciais no mapeamento cognitivo do fotógrafo. 0 Instagram foi utilizado como dispositivo de tagueamento dos locais das imagens, depois refotografados com uma

Campo Cego (2015)

Reproduç̃oes impressas em laser film para a montagem do fotolivro. 

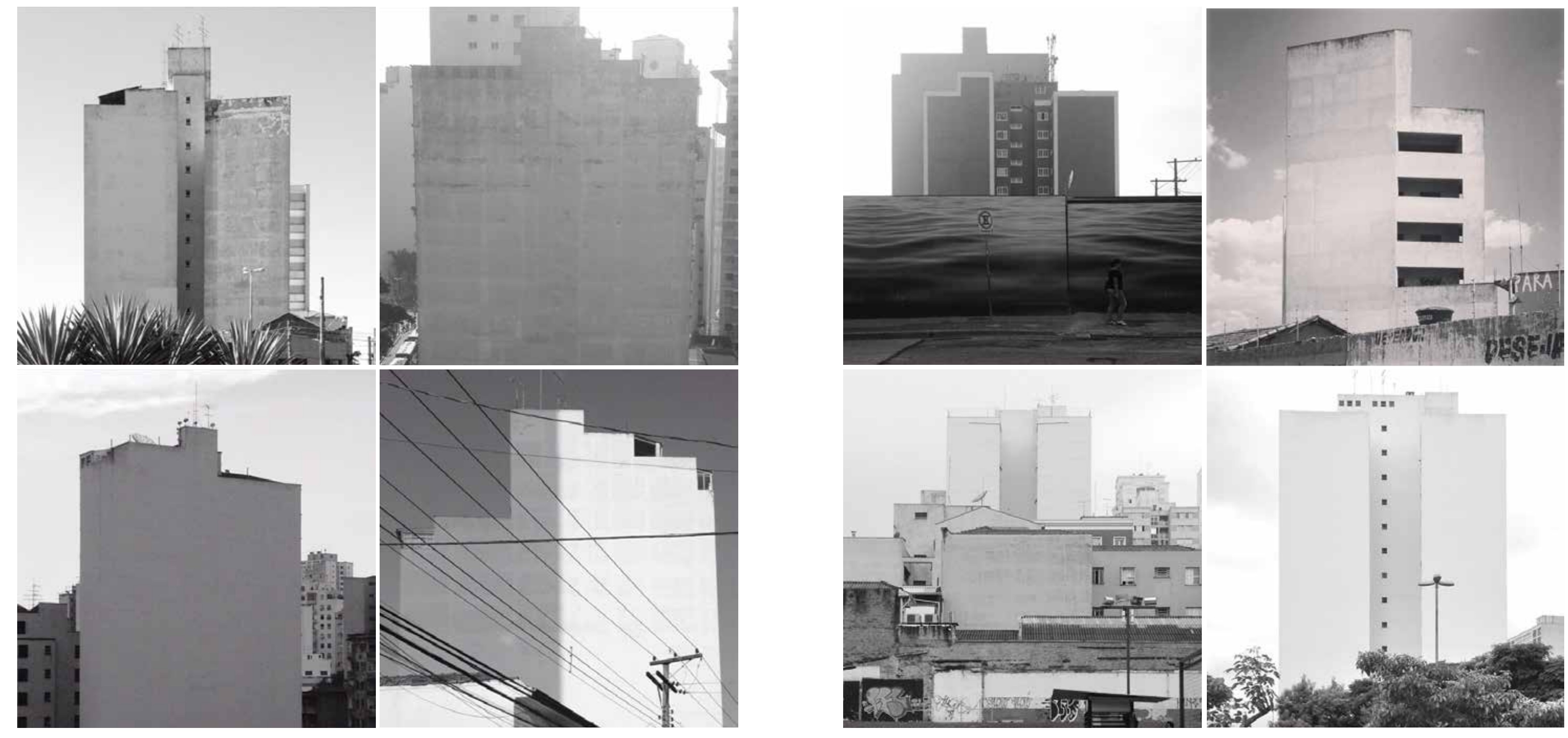

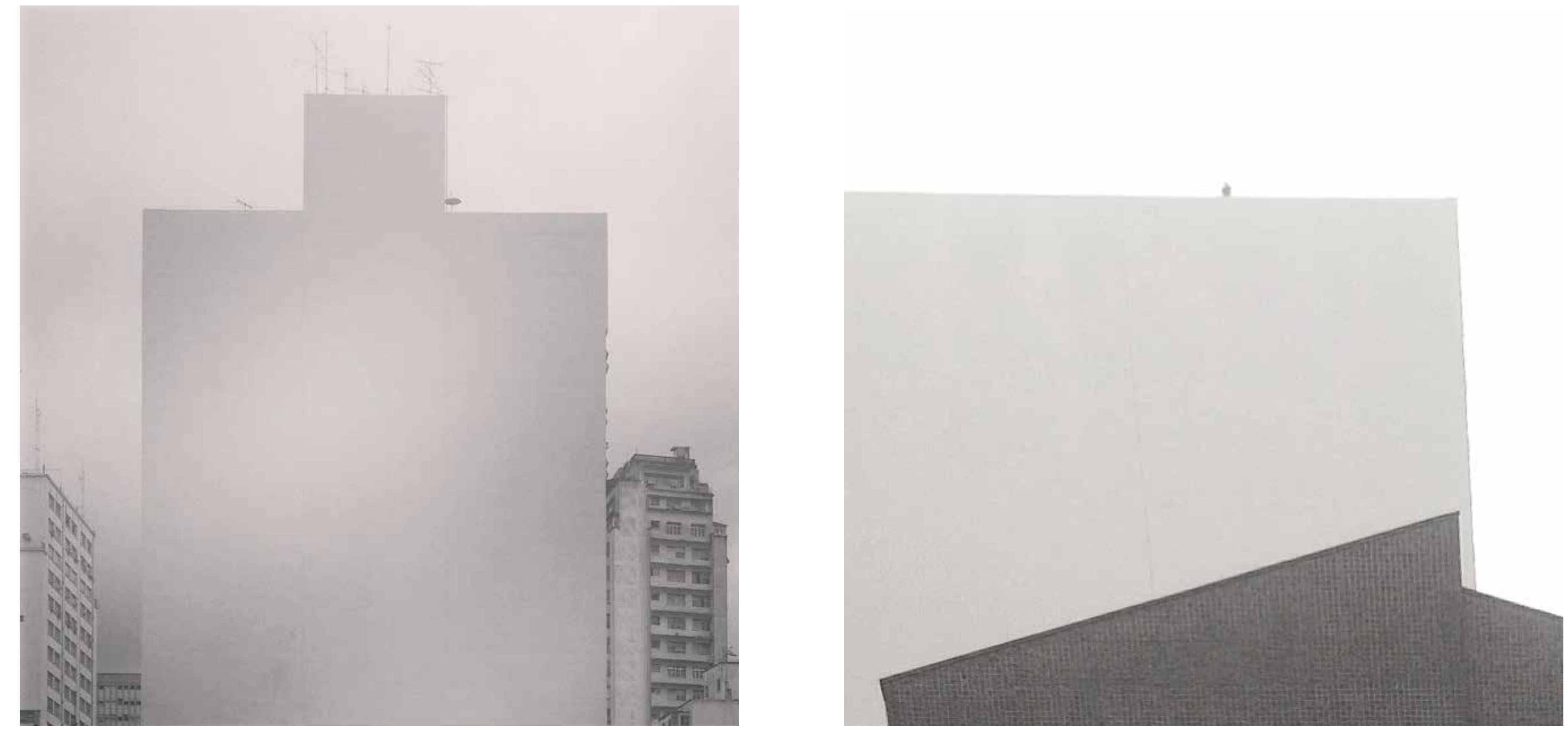

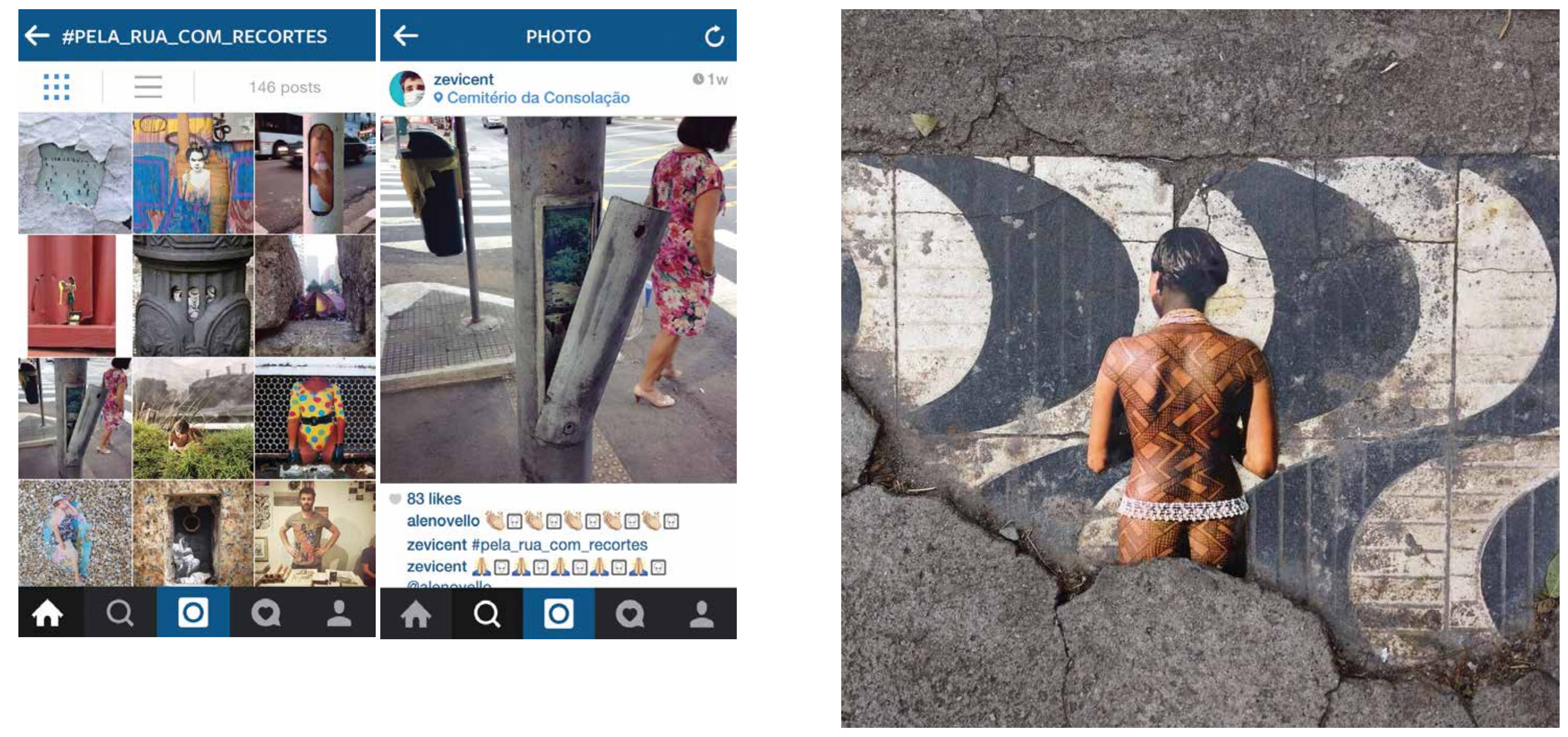

\#pela_rua_com_recortes (2014 - em andamento)

Zé Vicente

Infiltraçôes artísticas na cidade. Frestas e lugares ocupados e ressignificados. 

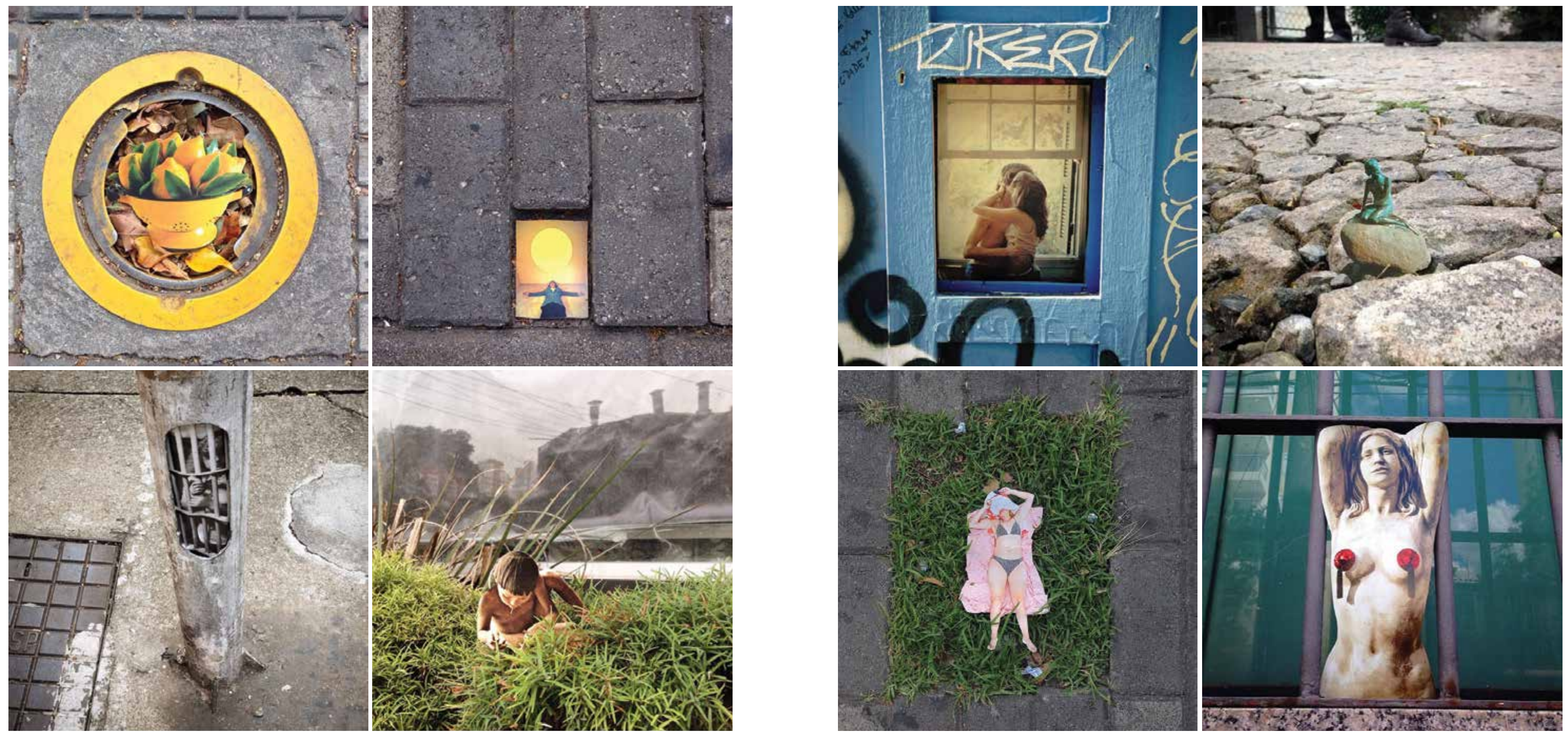

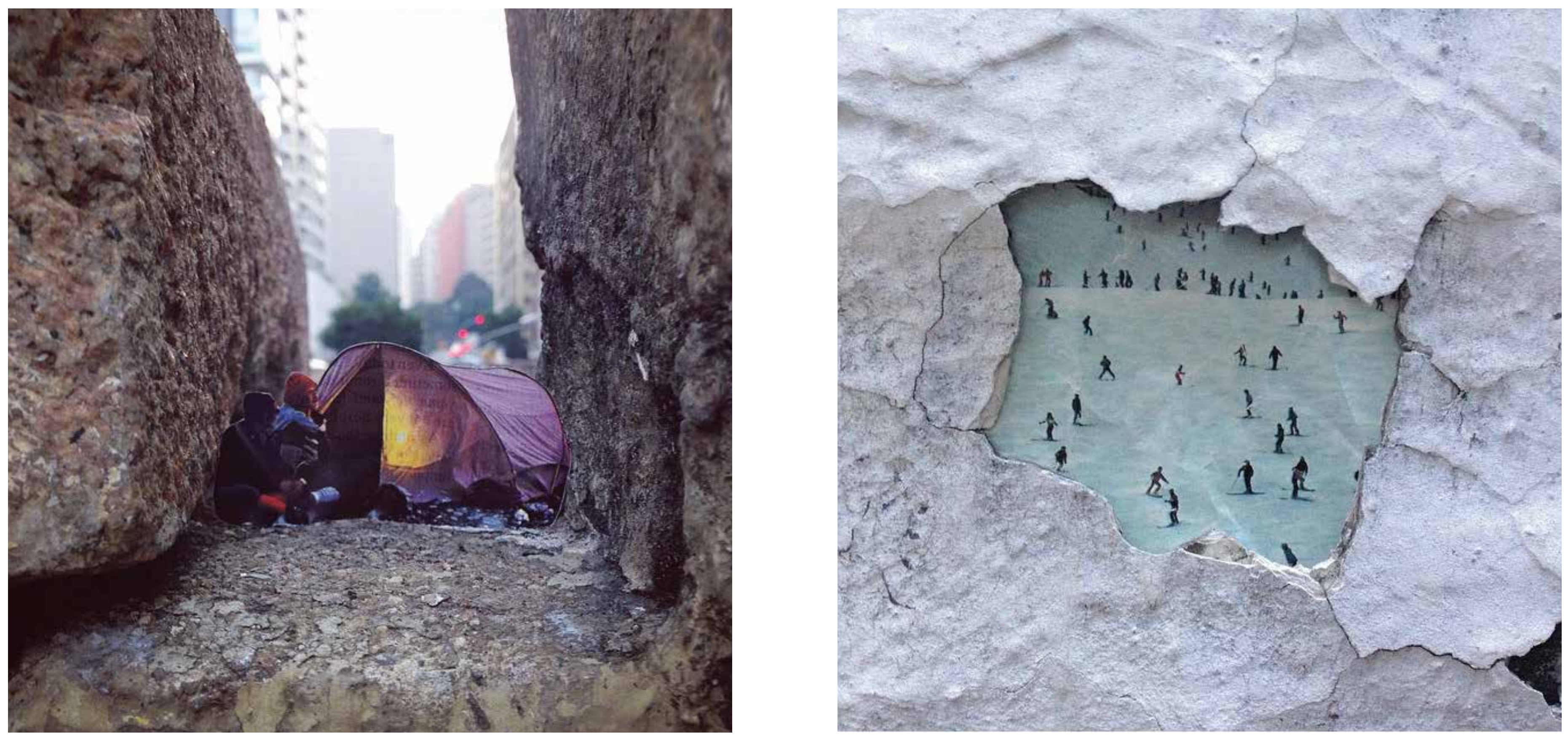

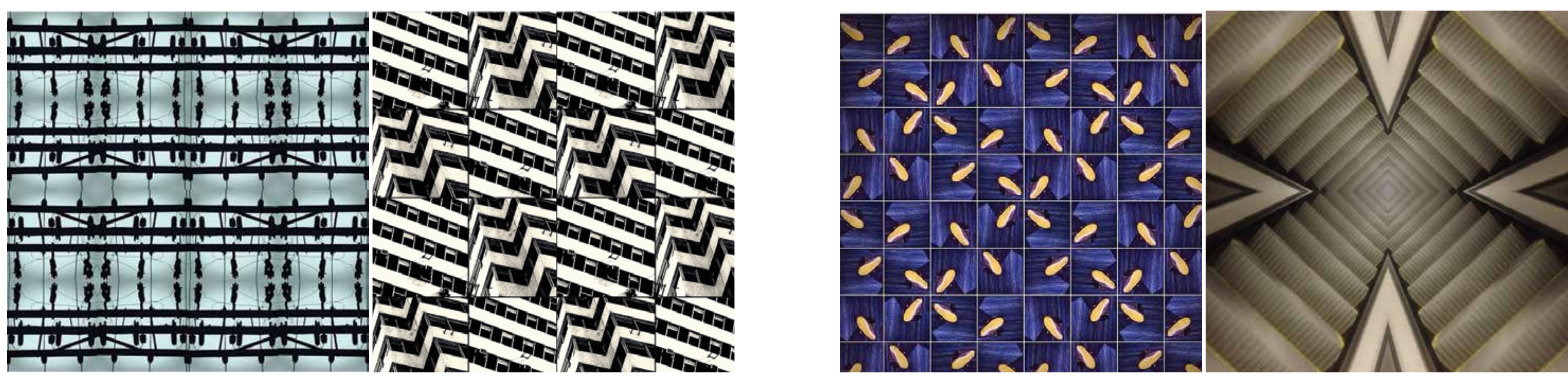

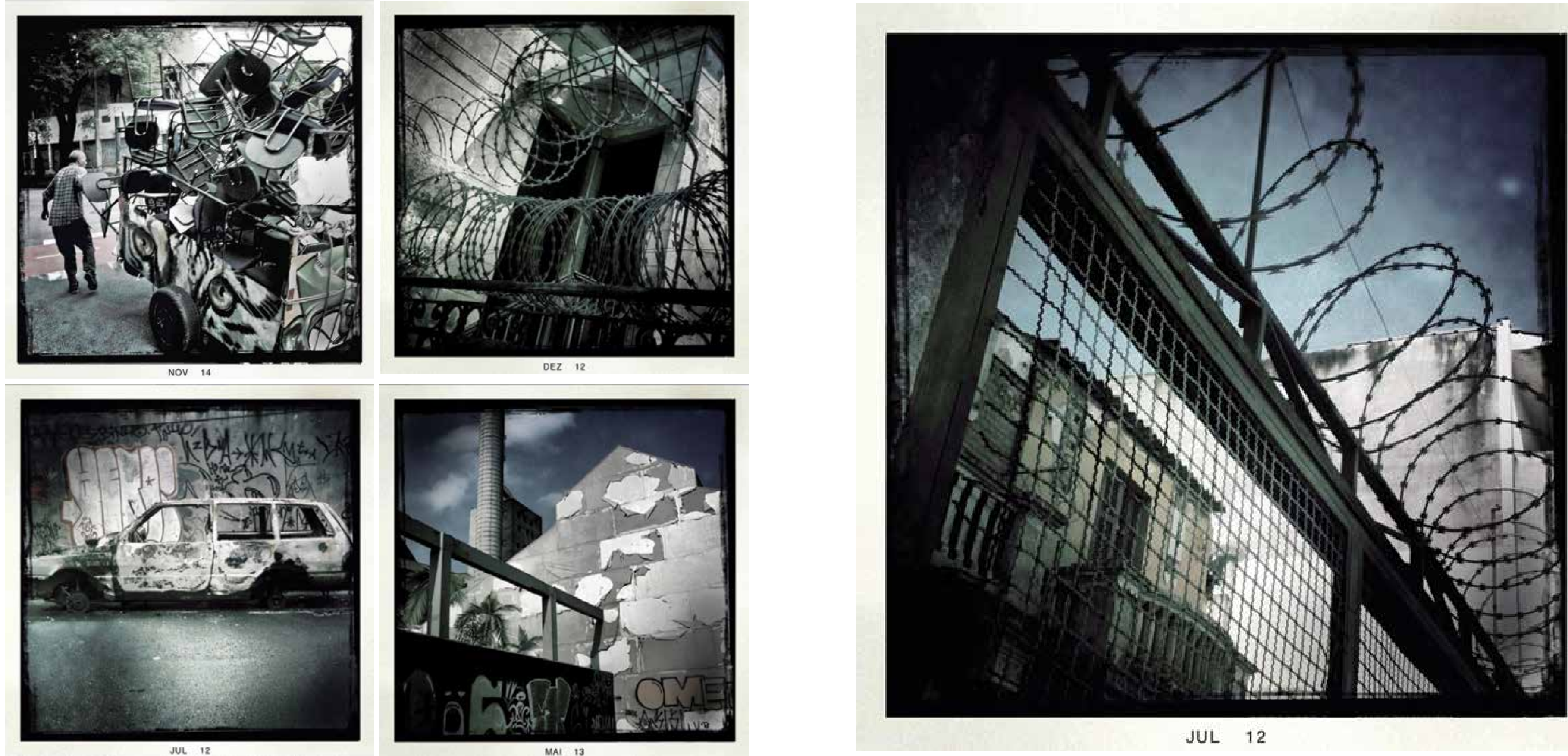

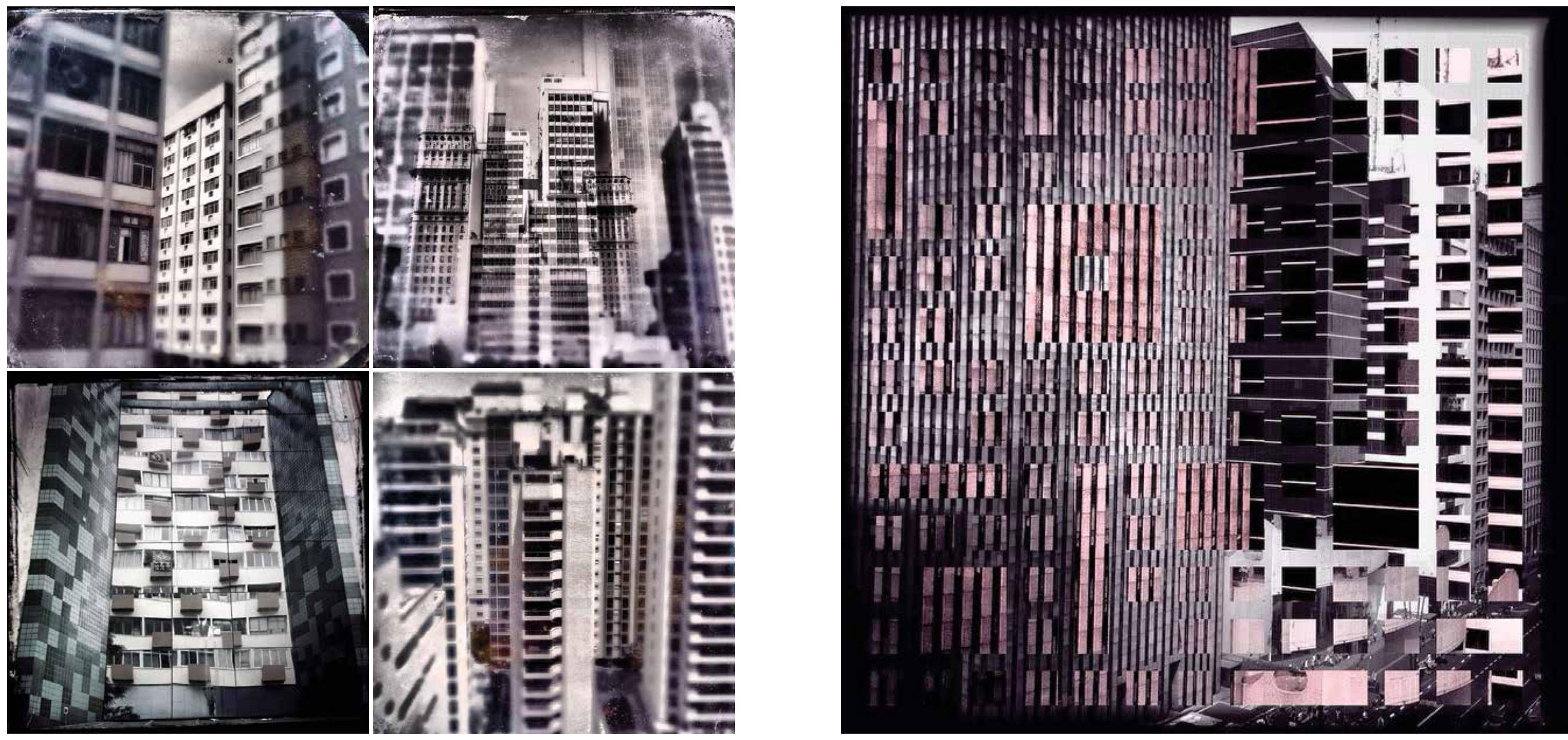

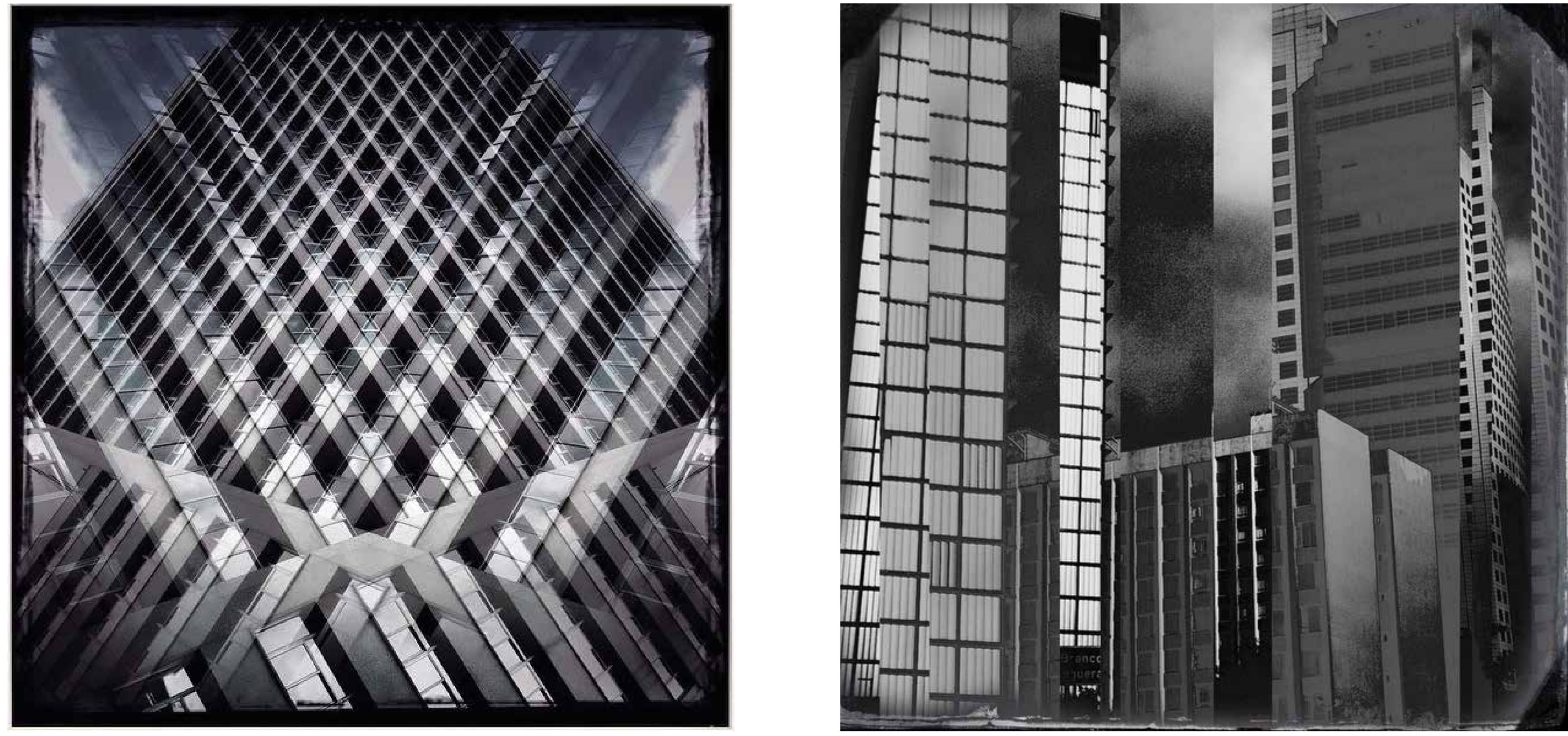

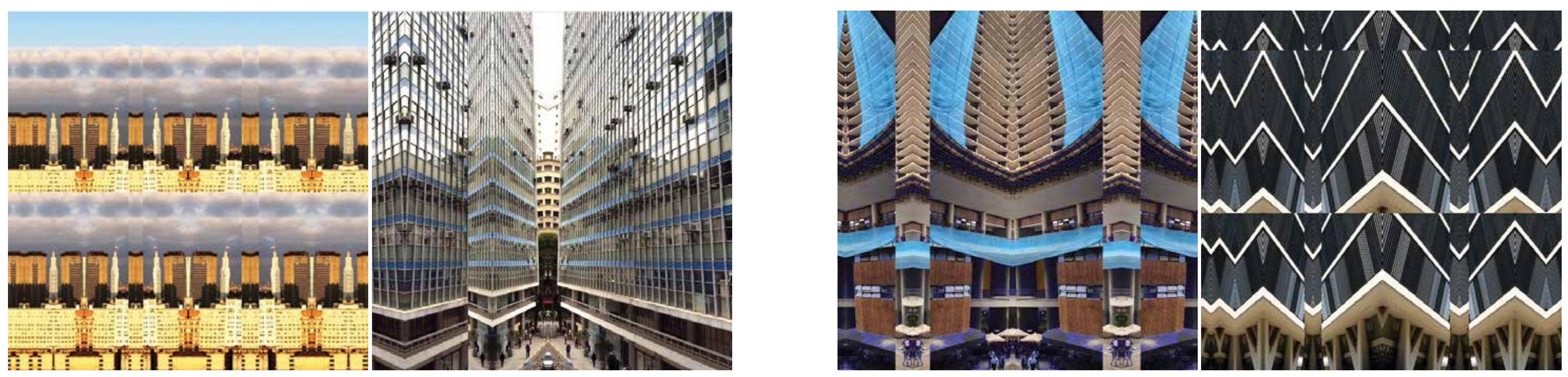

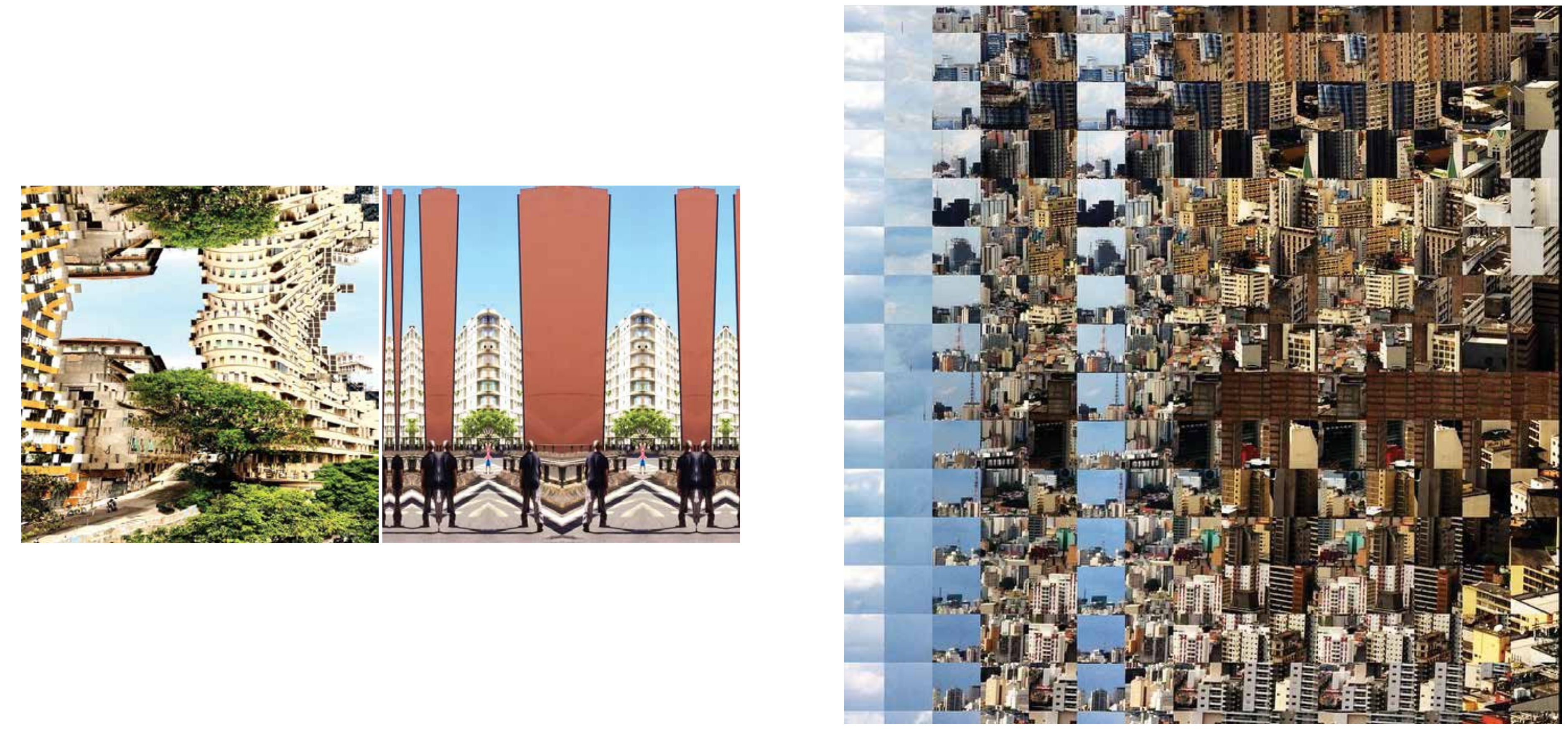
Fontes de imagens:

Todas as imagens do Instagram foram selecionadas no próprio aplicativo ou pelo Iconosquare, gerenciador de contas vinculado ao usuário @didianaprata.

92 


\section{Imageria e poéticas de representação}

da paisagem urbana nas redes

Narrativas nas redes:

Poéticas no fluxo midiático 


\section{Sumário}

VOLUME 1

Introdução mobile:

Contexto, natureza e singularidade

1.1. Multiculturalismo, tecnologia e consumo

1.2. Narrativa radicante

1.3. Superprodução de imagens e estetização do cotidiano

1.4. Imageria: novas potencialidades e funções da imagem

1.5. Natureza tecnológica e numérica

1.6. Redes informacionais

VOLUME 2

Arqueologia das narrativas visuais:

Do Atlas Mnemosyne (Warburg, 1924-1929) a

On Broadway (Manovich, 2014)

2.1. Derivas contemporâneas: estética do deslocamento

2.2. A Instamatic de Smithson e o Instagram de "qualquer um"

2.3. Narrativas imagéticas impressas e digitais

2.4. Let's participate and play

2.6. Um atlas atual e radicante

2.7. A linguagem híbrida e o espaço cíbrido

VOLUME 3

Imageria urbana: \#x

Caderno de imagen

\section{VOLUME 4}

Narrativas nas redes:

Poéticas no fluxo midiático

4.1. Imagens feitas para viajar

4.2. A arte como metalinguagem

4.3. A habilidade do metadado de agregar imagens

4.4. \# (hashtag) $+X$ (palavra-chave)

4.5. A volta do texto. 0 paradoxo da era cibernética

4.6. Criando narrativas a partir de novos contextos e dados

4.7. A frase-imagem

4.8. Estética coletiva e diluição do autor

Considerações finais 
Nesse capítulo trataremos de questões mais específicas pertinentes aos agenciamentos das narrativas visuais com imagens mobile. Analisaremos as imagens do caderno Imageria urbana a partir do novo regime imagético (RANCIÈRE, 2013), sua visibilidade e a potência de significação das narrativas imagéticas nas redes, e de seus atributos como artemídia (MACHADO, 2002). Veremos como se dá a transformação da imagem fotográfica fine-art em uma imagem acessível, de baixa resolução, a poor image, comprimida e digitalizada para ser mediada, para "viajar" instantaneamente nas redes (STEYERL, 2009). Trataremos também da dissolução institucional da arte na era das redes, a partir das contribuições de Hito Steyerl.

No tópico Relação texto e imagem nas redes, será explorada a relação de interdependência da imagem mobile com as hashtags e outros metadados que configuram e possibilitam a identificação das narrativas visuais no Instagram. Partiremos da análise de Wendt (2014) sobre os selfies (os autorretratos que constituem a imagem-símbolo da cultura de massa nas redes sociais) para nos aprofundarmos nas questões relativas ao uso de palavras-chaves e tagueamentos. Veremos com Beiguelman (2003) o hibridismo da linguagem escrita na internet e com Paul (2011) a configuração de contextos nas redes. O conceito da "frase-imagem", de Rancière (2013), contribuirá para a configuração das singularidades dessas narrativas no Instagram.

Por fim, abordaremos brevemente as questões da dissolução do autor, a partir de Foucault (1969). E a construção de estéticas coletivas e o novo papel do autor/artista na net art, com Diamond (2011) e Vesna (2007).

\section{Imagens feitas para viajar}

Voltamos ao exemplo da inauguração da ciclovia da Paulista em junho de 2015 quando cerca de 2.000 ciclistas passaram pela avenida. A grande maioria estava munida de seus celulares, com suas câmeras e dispositivos de tecnologia $3 G$ ou 4G. Não bastava vivenciar a experiência; era preciso documentá-la, mediá-la e compartilhá-la na rede.

A presença simultânea do paulistano no evento e nas redes sociais, como produtor e mediador de registros imagéticos daquele instante, ilustra a condição atual do homem contemporâneo conceituado por Rancière, por Lipovetsky e Bourriaud.

Em um primeiro olhar é inegável o viés afetivo, lúdico e banalizado dessas mensagens imagéticas. Os milhares de fotografias, visualizadas em conjunto, apontam, sob o ponto de vista formal, para a aparente negação dos elementos sensíveis de composição e iluminação inerentes ao trabalho artístico. 0 conjunto de imagens da \#cicloviapaulista reforça a participação social estetizada de um acontecimento líquido, fragmentado. Os filtros disponíveis nos aplicativos também contribuem para a mediação e edição da foto, ampliando as possibilidades estetizantes do jogo. É a imagem como mensagem, muitas vezes desprovida de sintaxe visual. É a imagem direta, como carimbo "eu fui", "estive lá".

Experiência similar ocorre com o conjunto de imagens tagueadas como \#parqueminhocao, \#rolevilamadalena ou \#Copan.

A transformação da imagem de qualidade em uma imagem acessível, produzida para ser mediada, para "viajar" instantaneamente nas redes, é uma das principais características da artemídia e fartamente explorada em trabalhos que envolvem televisão, vídeo e internet. 0 artigo da berlinense Hito Steyerl "In defense of the poor image" (2009) complementa o conceito de Rancière sobre imagérie - abordado no capítulo 1 - e traz à tona a força e importância 
da narrativa imagética que circula, em baixa resolução, nas redes. A autora não só desmonta o fetichismo acerca da imagem em alta definição, dependente da indústria, da produção de filmes e de editores para ser mediada, como defende a produção de linguagem específica para ser veiculada nas redes sociais, livre de produtores culturais, instituições, curadores, editores.

A imagem "pobre" já foi carregada [uploaded], baixada [downloaded], compartilhada, reformatada e reeditada. Ela transforma qualidade em acessibilidade [...]. É uma ideia visual em circulação, uma cópia em movimento, uma aceleração, um thumbnail, uma ideia errante, uma imagem itinerante, distribuída gratuitamente. (STEYERL, 2009, p.1)

A possibilidade de circulação de uma produção mais conceitual e independente é o ponto central do argumento da autora em defesa da circulação das "imagens pobres". Além disso, o acesso a produções de materiais audiovisuais raríssimos, de trabalhos ensaísticos, não comerciais, jamais veiculados anteriormente em circuitos convencionais e que agora foram disponibilizados em redes como YouTube, justifica a circulação de cópias e novas produções das poor images.

O paradoxo entre a livre circulação do novo sistema de produção e mediação de imagens e a dependência de redes como YouTube, Instagram, Facebook, Twitter, controladas por grandes empresas, é outro ponto importante levantado por Steyerl - assunto também tratado por Bastos e Beiguelman, conforme mencionamos no capítulo 1. Dependemos das redes, que são privatizadas, para veicular conteúdos e nossas narrativas e, também, para organizá-los em sistemas de edição apropriados a cada aplicativo, como acontece no Instagram.

Cabe perguntarmos: a longo prazo, qual o destino de galerias de fotos como \#cicloviapaulista, \#parqueminhocao e todas as demais que se tornaram representativas de um novo regime de imagem, dependente da tecnologia de um aplicativo privado, on-line?
Ao mesmo tempo, essas narrativas não existiriam sem a mediação do aplicativo, capaz de não só produzir linguagem, mas dar visibilidade a novas poéticas realizadas com imagens organizadas, repostadas e renomeadas em galerias visuais comuns, identificáveis pelo metadado, sua "legenda". o futuro dessas manifes tações de linguagem na rede é incerto, e sua sobrevida hoje depende de uma captura de imagens ou de uma edição digital, feita a partir dos API (Application Programming Interface)', para garantir sua visibilidade, ao longo do tempo, em outras interfaces que não dependam das redes sociais on-line onde foram publicadas e estão fragilmente arquivadas.

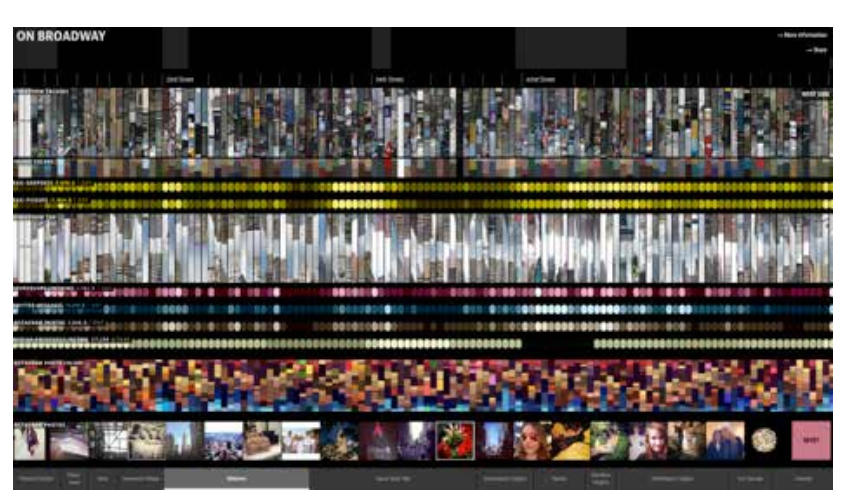

"On Broadway", 2014 - Lev Manovich e equipe. (Ver trabalho completo no capítulo 2, p. 28)

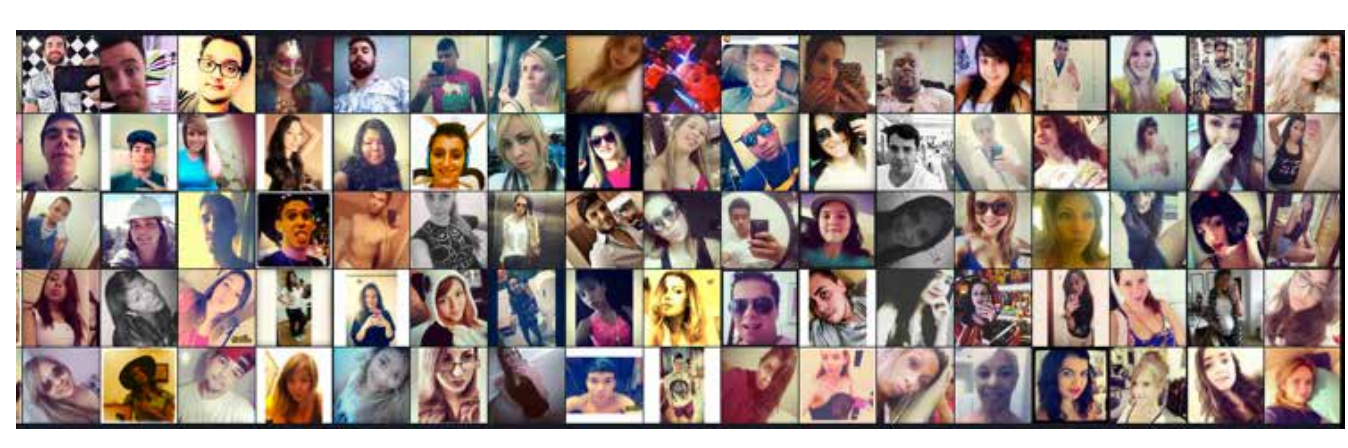

API - Application Programming Interface é um conjunto de rotinas e padrões estabelecidos por um software para a utilização das suas funcionalidades por aplicativos que não pretendem envolver-se em detalhes da implementação do software, mas apenas usar seus serviç̧os. 


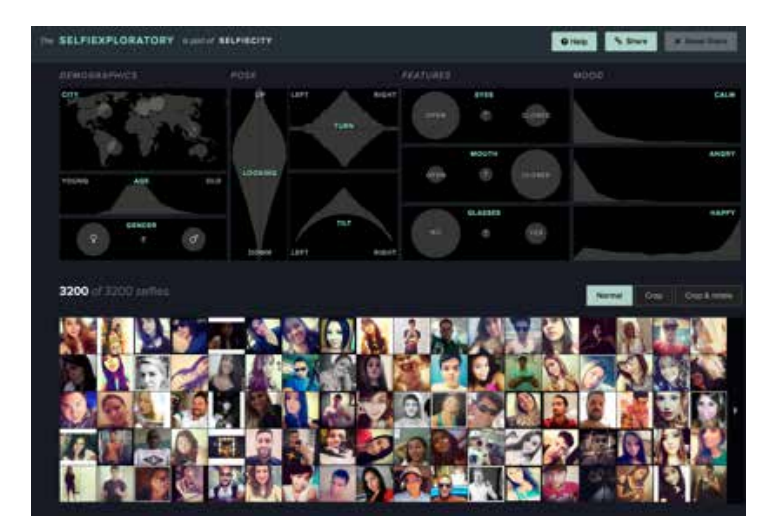

"Selfiecity.net", 2014 - Lev Manovich e equipe

" aplicativo inclui pesquisa teórica e ensaio visual sobre selfies no Instagram: primeiramente, a partir da pesquisa mecânica em um universo de milhares de imagens, selecionamos fotos de indivíduos sozinhos. Em um segundo momento, com o uso de algoritmos, foram selecionadas 3.200 imagens que melhor representam o comportamento e o padrão estético dos jovens em Bangkok, Berlim, Moscou, Nova York e São Paulo.

A edição de narrativas de "imagens pobres" no Instagram parte da pesquisa de superprodução de imagens nas redes e convive não só com o "lado B" da produção de material narcísico (os selfies), pornográfico, paranoico, mas também com outras imagens "sem discurso" definido e, sobretudo, com o controle dos aplicativos. Ou seja, estamos navegando em um território de produção de linguagem extremamente controlado, ao mesmo tempo líquido e, por que não dizer, volátil.

A extensão da visibilidade dessas narrativas em territórios tão desterritorializados faz parte desse novo regime de imagens e merece, certamente, ser reconhecida como uma manifestação de linguagem sem precedentes na história da imagem.

A submissão dessas narrativas ao regime contemporâneo de produção e distribuição de imagem redefine novas perspectivas para o valor de imagem. Steyerl ilumina essa questão com brilhantismo e situa com ineditismo a questão da circulação de imagens nos dias de hoje. Afinal, os trabalhos veiculados on-line, como os de Joachim Schmid, Erik Kessels, Dina Kelberman e Michael Wolf (capítulo 2, p. 40-53), mostram que a edição de imagens das redes e o colecionismo de imageria operam no mundo digital da "terra de ninguém". São imagens desprotegidas, de certo modo, de direitos autorais, que circulam muitas vezes em circunstâncias muito diferentes daquelas em que foram publicadas (devido a seu tagueamento, \# ou pin de geolocalização, ou sua reedição ou repostagem) e representam a estética da artemídia e da fotografia digital.

Em "Por um manifesto pós-fotográfico" (2011), Joan Fontcuberta conceitua a imagem digital na mesma chave que Steyerl. Define, de forma bastante provocativa, o estatuto da fotografia digital nas redes, a fotografia adaptada à nossa vida on-line:

[...] Os pontos fortes deste decálogo (nova consciência autoral, equivalência da criação com a prescrição, estratégias apropriacionistas de acumulação e reciclagem) desembocam no que poderíamos chamar de estética do acesso. (FONTCUBERTA, 2011). 


\section{A arte como metalinguagem}

Para tratarmos das especificidades narrativas da imagem mobile, vale retomar algumas definições do campo da artemídia. A busca de uma ética e de uma estética da era digital e a imbricação de mídia e arte, tratadas por Arlindo Machado (2002), fazem a conexão entre a imageria das redes e os trabalhos artísticos realizados com mediação tecnológica.

Como já visto no capítulo 1, essa nova forma de expressão artística apropria-se dos recursos tecnológicos, da mídia e da indústria do entretenimento em geral (sobretudo da televisão), intervindo em seus canais de difusão para propor novas alternativas qualitativas: "Não há também nenhuma razão por que esses produtos qualitativos da comunicação de massa não possam ser considerados verdadeiras obras criativas do nosso tempo, sejam elas consideradas arte ou não." (MACHADO, 2002, p.29).

Podemos ampliar essa definição, fundada a partir do estudo de produção de linguagem do mundo eletrônico e digital da videoarte, para incluir as narrativas produzidas com imagens mobile dentro dessa proposição. Os artistas-usuários, que hoje usam a rede como local de produção e veiculação de seus trabalhos, descobriram brechas e possibilidades oferecidas pelos softwares e pelo aplicativo Instagram (tagueamento personalizado, uso de geolocalização, livre distribuição de suas galerias de imagens) para produzir linguagem no meio do jogo de troca de imagens estetizantes entre os usuários.

Alguns artistas operam justamente na crítica aos meios e circuitos midiáticos, subvertendo as possibilidades, funções e finalidades. Eles "desprogramam" os circuitos, rompem e questionam a imageria produzida e veiculada nas redes, redefinindo e reinventando a produção de massa. Os trabalhos de Kessels, Schmid, Kelberman, Wolf, Beiguelman, já citados, são referências de artistas que lidam com a metalinguagem dentro das redes, tematizando por meio de coleções de imagens, discutindo e criticando o modus operandi da produção e circulação de imagens. Eles transformam essa estratégia em linguagem poética, ou, como diz Arlindo Machado, em "linguagem de sua mirada metalinguística" (MACHADO, 2002. p.27)

Por esse prisma, as produções de artemídia são singulares, mais subjetivas, desvinculadas do padrão industrial ou comunicacional predominante da tecnologia das redes. As "máquinas semióticas", segundo Machado, formalizam um conjunto de procedimentos conhecidos, herdados da história da arte e da fotografia, já assimilados pelo usuário leigo, comum, ao operar de forma livre sua "câmera".

Afinal, quem faz arte hoje obrigatoriamente enfrenta, a todo momento, a questão da mídia e seu contexto. E ao produzir e compartilhar suas imagens, o usuário nem sempre está ciente de que vivencia uma experiência estética.

\section{A habilidade do metadado de agregar imagens}

Antes de entramos na análise das narrativas visuais com imagens mobile - contextualizadas na chave da artemídia e subordinadas ao código escrito - é essencial mencionarmos o fenômeno dos selfies, os autorretratos, nas redes sociais.

Partiremos da análise realizada por Brooke Wendt em "The allure of the selfie" (2014) sobre o tagueamento de imagens com hashtags, para abordarmos uma questão fundamental da pesquisa, que diz respeito à natureza e singularidade das narrativas no Instagram: a relação entre a imagem e o texto, a legenda, a palavra-chave precedida de \# (hashtag). Ou do pin de geolocalização, um outro algoritmo escrito, rastreável na rede social Instagram.

O uso de hashtags personalizadas permite a organização dos ensaios com imagens mobile, postadas de maneira fragmentada, em dias e horas diferentes, 
Os selfies (autorretratos) parecem ser o símbolo do engajamento de usuários e seus seguidores. Contribuem para a superprodução de imagens ao se apropriarem de temas ou eventos para uma autoexposição e um exercício narcísico sem precedentes dentro da categoria self-portraits na história da fotografia (WENDT, 2014).

Essas imagens evidenciam o padrão de comportamento de estetização do cotidiano dos jovens e levantam questões de pertencimento, identificação e ideação narcísica de uma geração cíbrida (ver trabalho de Manovich à p. 8). Os selfies de usuários no mundo todo apresentam padrões formais muito semelhantes, reconhecíveis em sistemas de leitura de "proxy", programados para detectar, a partir do posicionamento e da forma dos pixels, rostos (STEYERL, 2014).

Wendt cita o aplicativo Instagram como o grande definidor do "look" da geração atual. 0 \#selfie e o \#selfportrait passaram de 439 milhões em junho de 2014. A autora utiliza-se de uma frase de McLuhan, pioneiro nos estudos da relação homem-tecnologia, para elucidar esse fenômeno: "o homem se torna fascinado pela sua extensão em outras superfícies extensivas a ele" (MCLUHAN, 1994, apud WENDT, 2014, p.7). No Instagram, ocorre situação similar, e o jogo entre seguidores estimula a ubiquidade dos selfies como uma marca de distinção.

O comportamento pré-redes sociais e pós-redes sociais marca o modo das nossas expressões. Nas redes, somos fragmentos de nós mesmos, mediados por um retrato, uma porção de nós. 0 uso das hashtags que acompanham os autorretratos nos traz um dado muito interessante, inerente ao funcionamento do Instagram, aplicável às narrativas visuais pesquisadas neste estudo. Conecta-se também com o conceito de frase-imagem de Rancière, que abordaremos adiante. Ao usar a palavra "selfie", o usuário passa a autodenominar-se um metadado. E perde toda a individualidade e a "diferença" no meio de todos os milhões de selfies. O mesmo ocorre com todas as superproduções de imagens tagueadas com a mesma hashtag: \#cicloviapaulista, \#copadomundo, \#taescritoemsampa, \#parqueminhocao, para citar algumas.

A relevância do "fenômeno" dos selfies mereceria ser analisada com mais profundidade, entretanto, não caberá neste espaço, no qual focaremos as representações imagéticas da paisagem urbana.

\section{\# (hashtag) + X (palavra-chave)}

As câmeras celulares "como um terceiro olho na palma da mão" (BEIGUELMAN, 2011) aceleram a produção e veiculação imediata de imagens, muitas vezes precipitada, de percepções sobre as coisas ou acontecimentos. Como a ordem do dia é comunicar por imagens, produz-se uma quantidade de imagens "vazias", sem qualquer expressividade, que passam a ser visíveis apenas quando agrupadas por uma hashtag comum. Em busca de visibilidade e "likes", os usuários passam a taguear suas imagens com uma legenda popular, reconhecível pelo sistema algorítmico dos computadores. Daí a ubiquidade relacionada a diferentes instâncias de visibilidade das fotos, por usuários muitas vezes de localidades e culturas diferentes, fora do circuito de amigos ou seguidores de quem postou a foto.

Os artistas apresentados no caderno Imageria urbana utilizam-se da mesma estratégia de tagueamento. Suas narrativas são organizadas e visualizadas a partir desse artifício: cria-se uma hashtag personalizada para a edição de um ensaio exclusivo, uma galeria virtual de imagens. Esse grupo de "usuários" não está interessado, em um primeiro momento, no número de "likes", como o grupo descrito no parágrafo anterior. Não estão interessados em qualquer tipo de visibilidade, não serão rastreados facilmente pelas buscas algorítmicas, mas se beneficiam da potencialidade dessa função do código escrito, do metadado, para nomear e circular seu trabalho. 


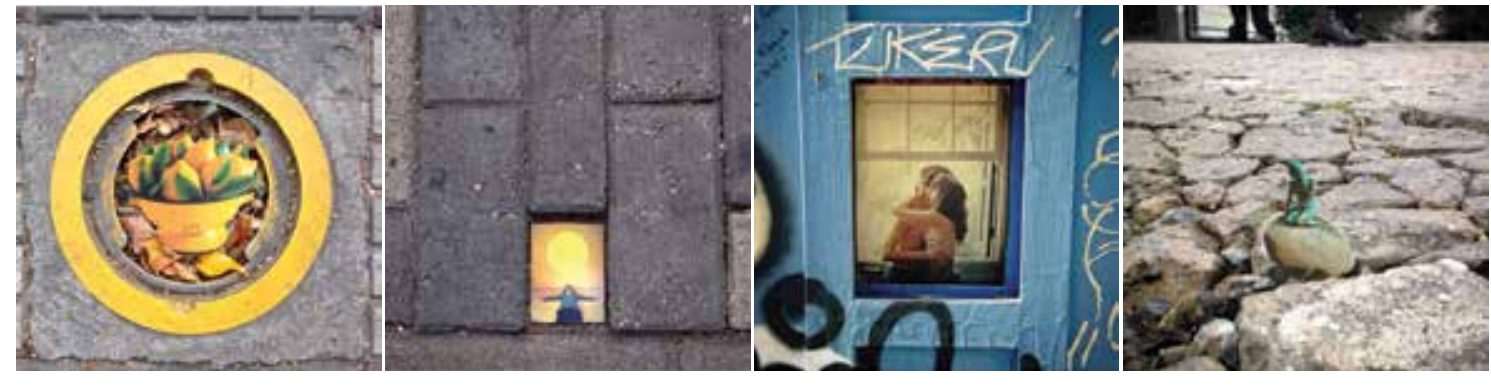

. Humor e ironia fina ao revelar camadas e superposiçōes da deterioração das coisas urbanas.

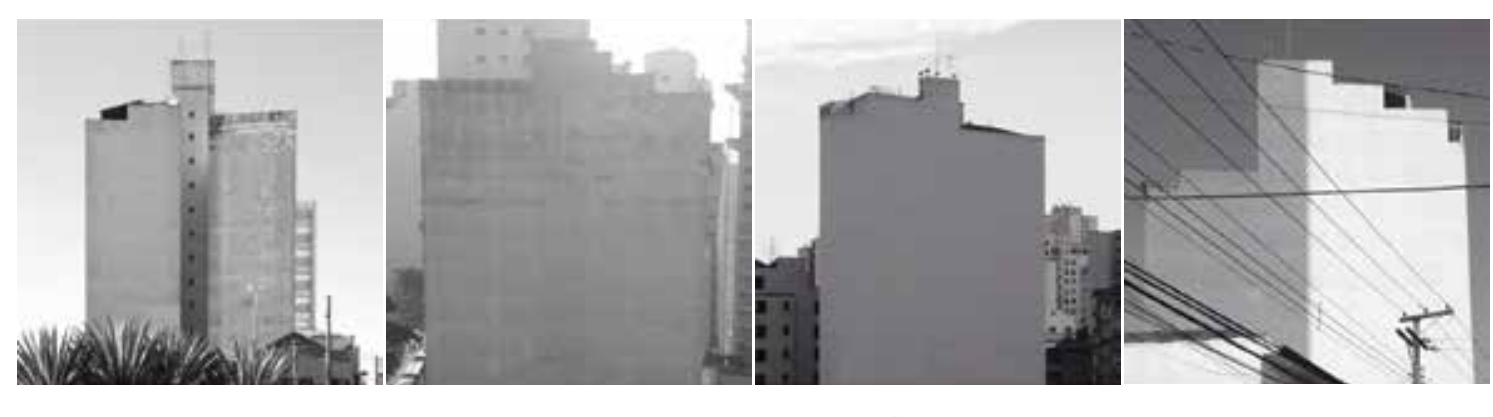

\#campocego - Ivan Padovani - mapeamento das empenas de São Paulo. Esses monolitos brancos passam a ser os marcos referenciais no mapeamento cognitivo do fotógrafo. O Instagram foi utilizado como dispositivo de tagueamento dos locais das imagens, depois refotografadas com uma câmera de grande formato para a produção de um fotolivro.

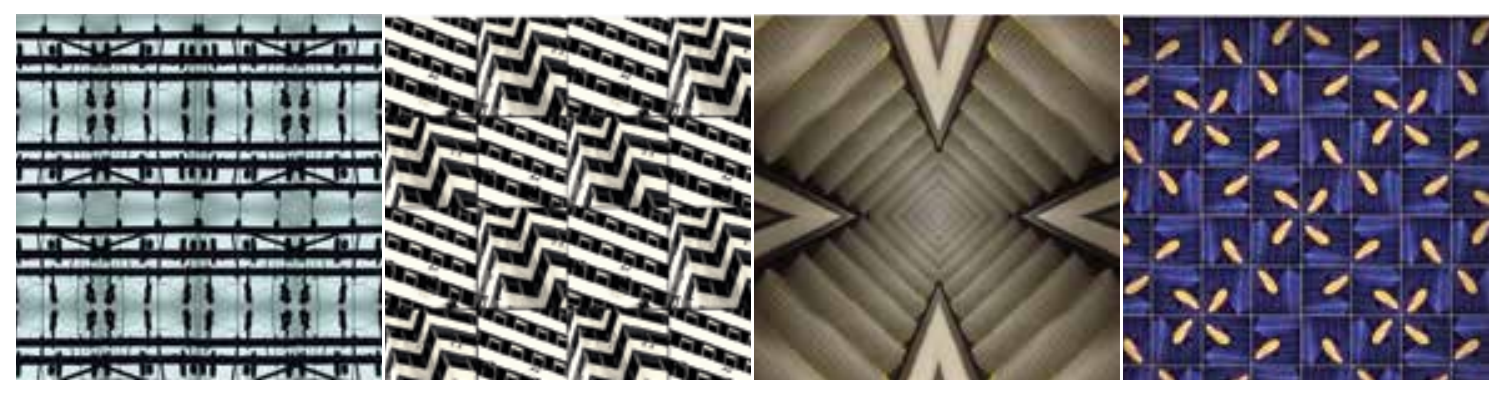

\#gambiologica - Hernani di Mantas - pattern de superfícies urbanas.

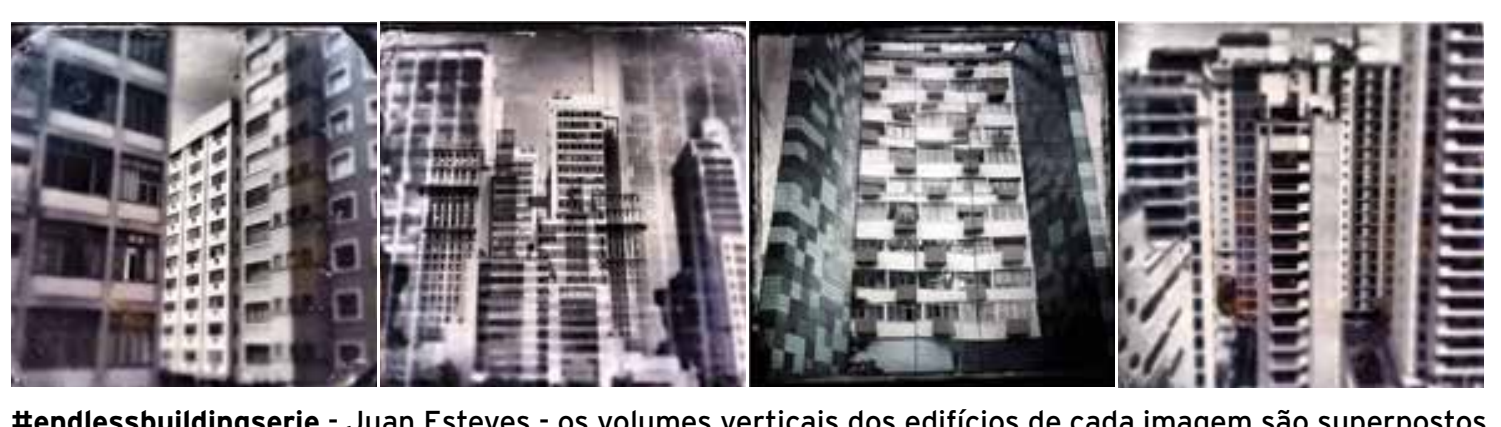

\#endlessbuildingserie - Juan Esteves - os volumes verticais dos edifícios de cada imagem são superpostos por meio de uma colagem realizada com filtros do Hipstamatic - aplicativo usado para produção e edição,
As referências ao lado exemplificam a estratégia de artemídia descrita por Arlindo Machado: esses artistas driblam o default da tecnologia do aplicativo Instagram para produzir linguagem, para criar e circular seus ensaios em galerias personalizadas, organizadas por hashtags (ver ensaios completos no caderno Imageria urbana, p. 65-91).

\section{A volta do texto. 0 paradoxo da era cibernética}

Qual a intenção de escrever para mediar imagens?

Com o uso de hashtags no Instagram, acabamos por consumir mais imagens do que deveríamos e deixamos de contemplar ideias e ensaios sobre outras imagens que desaparecem na rede (podem estar escondidas) devido ao sistema de armazenamento volátil e ao mecanismo bastante restrito do sistema de busca (apenas por autor, hashtag ou localização geográfica). O uso do código escrito, da palavra-chave, torna-se fundamental para a sobrevida da imagem no Instagram.

Para Flusser, a intenção de escrever para mediar os homens e suas imagens pode obscurecer as imagens em vez de representá-las, e insinua outro tipo de relação entre os seres humanos e suas imagens (FLUSSER, 1984, apud WENDT, 2014). Segundo Wendt, a hashtag aparenta ter esse efeito sobre a imagem. Ela imediatamente desencanta, quebrando a imagem em um simples conceito. A posição de Wendt é discutível; talvez se aplique mais aos selfies, pois restringe uma série de encadeamentos de narrativas imagéticas, como visto nos trabaIhos acima. De todo modo, levanta questões importantes relacionadas ao texto e à imagem nas redes.

Da forma como a internet está programada, a imagem que circula na rede será priorizada, ou melhor, terá mais visibilidade se contiver uma palavra-chave, hashtag, título, link, ou seja, um metadado que a transforme em imagem visíve 
a uma audiência não humana. Desta forma, o algoritmo da imagem precede a imagem. (RUBINSTEIN; SLUIS, 2013, apud WENDT, 2014).

A partir da análise de Wendt, vimos que a hashtag junto à imagem passa a ser fundamental. Esse dado aponta para o paradoxo da invisibilidade das imagens nas redes. Provavelmente, uma função não intencional do Instagram, mas um fato fundamental para a análise das narrativas digitais e para o estudo da estética do banco de dados digitais.

Em tempos nos quais nos comunicamos cada vez mais por imagens, temos que estar conscientes de que nossas narrativas, retratos, imagens afetivas de familiares ou qualquer produção estética serão transformados em dados quantitativos, distribuídos pelo Instagram ou por outras redes e, ironicamente, subordinados ao código escrito.

As narrativas líquidas, submetidas aos armazenamentos e códigos da escrita, são tratadas por Giselle Beiguelman em O livro depois do livro (2003). A autora analisa a transformação do texto nos suportes digitais e o hibridismo da linguagem textual no ciberespaço.

Um texto que se transmite em um fluxo de dados contínuo e que demanda pensar um contexto de leitura líquida que não responde ao desenho retangular da janela do monitor nem ao enquadramento da página. Redefinem-se não só as experiências de leitura, mas os lugares de leitura, porque se tornam agora relativas as diferenças entre texto, imagem e lugar, muito embora a metáfora da tela com a página mascare essa situação inédita. Não importa se o que é visto é texto ou imagem. O que pode ser lido, visto ou escutado depende de uma rota textual de endereçamento que não reside na tela, mas que faz o texto se confundir com a noção de lugar e transforma a imagem e o som em um dado da escrita. (BEIGUELMAN, 2003, p.18).
Esse fenômeno, levantado por Beiguelman a partir da experiência da passagem da narrativa linear, do livro impresso, para o livro digital, se aplica às narrativas imagéticas produzidas, manipuladas, reendereçadas e reindexadas nas redes. Podemos dizer que a autora antecipa a grande questão do ciberespaço: o domí nio do código escrito "invisível", ainda quando não havia Facebook nem Instagram e outras redes sociais.

No panorama atual das redes informacionais, no qual a imagem é utilizada como estratégia de linguagem estética e comunicacional predominante, a subordinação da imagem ao metadado levanta um problema cada vez mais complexo: a interdependência entre palavra e imagem.

Por outro prisma, vale lembrar que no contexto de imageria nas redes, a pesquisa de imagens ou a apreciação de um ensaio temático não estão limitados pelas hashtags e pelos sistemas de buscas do aplicativo. A percepção dessas narrativas depende fundamentalmente da ação cognitiva do olhar, está associada a uma experiência sinestésica entre o usuário e as imagens visualizadas na tela.

As imagens que aparecem expostas na tela do Instagram dependem da interação do usuário e de suas escolhas, seus atalhos, buscas, nomeações e apropriações algorítmicas, como definição do uso do pin georreferenciador e a escolha das hashtags (palavras-chaves). Essa experiência tecnestésica (COUCHOT, 2003) pode também ser considerada uma estratégia "tecnoestética". Une o indivíduo e os dispositivos tecnológicos, potencializando todas as etapas de produção, mediação e recepção, em infinitas camadas de leitura. Há um desdobramento imponderável dos agrupamentos de imagens, novas narrativas não-lineares, fragmentadas, colaborativas, em outro tempo-espaço. 


\section{Criando narrativas a partir de novos contextos e dados}

Redes, particularmente as sociais, são as narrativas dominantes das novas artes na mídia e esta constatação fornece uma bagagem histórica de como essas redes se envolveram e moldaram a arte e a cultura contemporânea. (PAUL, 2011, p.104, tradução nossa).

A construção de significado ou de representações estéticas nas redes depende também da flutuação do contexto e do movimento das redes. "Contexto" para Paul está relacionado a uma localização e enriquece as especificidades de um lugar particular atribuindo-Ihe novas características. A autora investiga como a rede de informação reconfigura esses contextos e afeta a produção do significado. Para ela esses condicionantes se aplicam no processo de representação de dados da rede e também afetam a formação de identidade, os sistemas sociais e a produção cultural.

As novas ferramentas das tecnologias digitais, como links e filtros, nos ajudam a entender a cultura hoje. 0 processo de dados coloca o texto (ou, em outras palavras, os tagueamentos) como questão central da informação e do contexto, e dá suporte a um sistema com várias camadas "interpretativas": um texto pode estar relacionado a diferentes contextos e, dependendo dos links "embedded", provocar novos contextos extensivos, muitas vezes bem distantes do "texto" original.

O aplicativo e plataforma Instagram nasceu da ubiquidade do ciberespaço, as sim como as novas plataformas de produção cultural que passam a formar uma comunidade ad hoc.

Paul entende a arte produzida com mídia locativa como a nova forma de arte pública. Esta pode ser translocal e site-specific.
Este recurso encontrou um amplo espectro de atuação para a prática artística que inclui a anotação e apreensão de espaços urbanos e da paisagem com informação: narrativas georreferenciadas, engajamento crítico como efeito cultural do uso da tecnologia mobile. E o aumento do agenciamento das pessoas através da reunião de dados "data gathering". (PAUL, 2011, p.107, tradução nossa).

Os dados reais e virtuais se juntam nas redes sociais. Seguindo esse raciocínio podemos dizer que plataformas como o Instagram são os "ready for use" de distribuição com a facilidade de oferecer uso de filtros para edição das imagens e links informacionais (novos tagueamentos que acionam e ampliam a redes de contato com aquela imagem/mensagem), como um verdadeiro broadcast de narrativas visuais.

Paul levanta ainda um problema que nos parece bem pertinente: o usuário pode desistir da autoria do que produz, mas suas informações pessoais estão sujeitas a "datamining" para fins comerciais. Estamos transitando e trocando nossas experiências estéticas e pessoais cada vez mais em um espaço que se apresenta como "cultural common". O conceito de rede comum está interconectado com a noção de domínio público.

O uso das tags (\# e pin de georreferenciação no caso do Instagram) traz novos paradigmas classificatórios em um contexto de produção dinâmica: "a classificação cria o contexto para a produção do significado, na qual a massa crítica de usuários determina, ou pelo menos ajuda a modelar, o significado" (PAUL, 2011, p.110, tradução nossa). 


\section{A frase-imagem}

Voltamos a uma abordagem mais filosófica sobre a imagem das redes para introduzir o conceito da "frase-imagem", o qual complementa a compreensão das narrativas coletivas no Instagram, a partir de um viés mais semântico.

Em O destino das imagens, Rancière (2013) afirma que, no mundo contemporâneo, as imagens não estão subordinadas ao texto. $E$ a combinação desse jogo, imagem-texto ou texto-imagem, instituiu novos modos de manifestações artísticas. O autor cita Histórias do cinema, de Godard, como o exemplo perfeito de mistura de apropriação de campos da arte e recusa ao purismo das artes de vanguardas (autônomas).

Rancière associa a operação metamórfica da imagem, usada por Godard, com o cubismo, com fragmentos que se somam num jogo simbólico, por meio de metáforas. Cita também Wodiczko e suas projeções nos monumentos oficiais americanos das imagens dos moradores de rua, expulsos pela renovação urbana em Nova York, como um trabalho que também opera elementos heterogêneos em uma montagem simbólica.

É a partir desses exemplos, dessas misturas de linguagens e materialidades que 0 autor introduz o conceito da frase-imagem, a grande parataxe. A imagem pode se manifestar na relação do dito e do não-dito na fotografia. A imagem não é função para tornar o verbo carne. A imagem tornou-se potência ativa de trans formação de um regime imagético. A frase-imagem retém a potência da grande parataxe em uma sintaxe, a partir da junção e do choque de elementos heterogêneos, para fornecer uma medida comum (RANCIÈRE, 2013, p.54-65).

O autor ainda aprofunda os tipos de frase-imagem, aplicando-as ao teatro, ao cinema, à fotografia. Para nós, interessa justamente a questão da visibilidade do "contínuo", que está além do fragmento de imagem, na possibilidade de imagi-
O conceito de frase-imagem nos ajuda a entender a predominância das imagens nas redes dentro de um contexto mais singular: a partir da junção de imagen heterogêneas, colocadas lado a lado pela edição da mesma palavra-chave, como vimos nas edições do caderno Imageria urbana.

O uso da parataxe para a construção narrativa ainda pode ser ampliado e customizado a partir do cruzamento de metadados (\#, pin de geolocalização ou nome do autor), somado à edição cognitiva do artista. Por meio do encadeamento de imagens aparentemente sem relação entre si, obtêm-se infinitas combinações, novas conexões estéticas. Aqui, a imagem predomina e possibilita a construção de novas poéticas, mesmo estando codificada por um código escrito na rede. $O$ metadado (a hashtag) passa a ser muito além de um dado numérico: ele é a pe ça-chave da construção narrativa no Instagram. E essa narrativa visual obedece a uma lógica inversa à lógica da narrativa textual (literária), na medida em que os fragmentos colocados lado a lado na maioria das vezes são aleatórios e não estão dispostos em uma sequência lógica, não obedecem a um enredo preestabelecido, mas constroem a poética narrativa das redes. Os dípticos e polípticos realizados a partir da apropriação de imagens no caderno Imageria urbana (à p. 48-63) são exemplos dessa estratégia. Vale citar também os trabalhos de Dina Kelberman e Penelope Umbrico apresentados no capítulo 2.

\section{Estética coletiva e diluição do autor}

A questão da autoria das produções artísticas distribuídas nas redes tem sido objeto de estudo de alguns autores, como Bourriaud (2011) e Navas (2004), os quais relacionam a cultura remix, introduzida pelos DJs dos anos 70 e 80 , com a representação cultural do século XXI. Destacamos também o uso de informações e de imagens de banco de dados para fins artísticos, a partir de Vesna (2007). 
É a cultura da apropriação, do copy/paste, do deslocamento de significados em novos ready-mades, conforme demonstram as diversas formas de narrativas encontradas nas redes. Não vamos nos aprofundar nesse tema tão abrangente da autoria, mas abordaremos a questão como uma das características dessa prática estética, a partir de Foucault (1969), Diamond (2011) e Vesna (2007).

Em 1969 Foucault já se perguntava: “O que é um autor?".

O autor é ainda o que permite superar as contradições que se podem desencadear em uma série de textos: ali deve haver - em um certo nível do seu pensamento ou do seu desejo, de sua consciência ou do seu inconsciente - um ponto a partir do qual as contradições se resolvem, os elementos incompatíveis se encadeando finalmente uns nos outros ou se organizando em torno de uma contradição fundamental ou originária. 0 autor, enfim, é um certo foco de expressão que, sob formas mais ou menos acabadas, manifesta-se da mesma maneira, e com o mesmo valor, em obras, rascunhos, cartas, fragmentos etc. (FOUCAULT, 1969).

Interessante associar o questionamento da origem do autor feito por Foucault às questões relativas à autoria das narrativas coletivas no Instagram. O deslocamento dos campos discursivos em torno de uma mesma ideia ou tema "de origem", bem como as reedições e apropriações de uma narrativa, seja ela imagética ou literária, permitem-nos indagar sobre as camadas justapostas das autorias individuais - do eu (ou ego) - e das coletivas, organizadas em torno de um discurso comum.

A estruturação das narrativas visuais no Instagram está subordinada ao uso de uma palavra-chave/tema principal. Foucault revela como os signos da mensagem, do relato do narrador, podem estar mais próximos ou mais distantes de seu discurso poético: "todos os discursos que possuem a função-autor compor- tam essa pluralidade de ego", diz (FOUCAULT, 1969).

Segundo Foucault, a "função-autor" é complexa e pode ser analisada a partir de assinaturas definidas (autorais) ou em conjuntos mais amplos, a partir da "tipologia de discursos": podemos retirar do sujeito seu papel de fundamento originário e analisá-lo como uma função variável e complexa do discurso. E termina: "os modos de circulação, de valorização, de atribuição, de apropriação dos discursos variam de acordo com cada cultura e se modificam no interior de cada uma; a maneira com que eles se articulam nas relações sociais se decifra de modo, parece-me, mais direto no jogo da função-autor e em suas modificações do que nos temas ou nos conceitos que eles operam" (p.28). Trata-se do apagamento do autor em "proveito das formas próprias ao discurso".

Esse desaparecimento do autor nos permite descobrir o jogo da função-autor do qual estamos constantemente participando. Transpondo a questão para a realidade das redes, podemos dizer que os transdiscursos das narrativas do Instagram têm várias origens e fazem parte dessa composição autoral realizada por vários autores na elaboração de uma operação de linguagem poética coletiva. $\mathrm{O}$ uso de apropriação faz parte desse jogo da função-autor na medida em que não importa a origem da primeira ideia ou imagem e sim o contexto. Ou seja, o prefixo "trans" introduzido por Foucault - dentro do contexto sociocultural que antecedeu a revolução de maio de 68 na França - se aplica perfeitamente à transdiscursividade das operações das imagens organizadas pelos algoritmos das hashtags nas redes informacionais de hoje.

Nas narrativas do caderno Imageria urbana, observa-se uma predominância do tema sobre a autoria, o que nos permite aproximar os dois conceitos apresentados aqui. A "frase-imagem" de Rancière se relaciona com a composição visual das narrativas das redes em torno da palavra-chave, enquanto o conceito de "função-autor" de Foucault se aplica ao discurso do conjunto dessas imagens, no qual há um apagamento da autoria. 
Para o autor que participa desse jogo das narrativas visuais constituídas por um \# temático comum, sua imagem é única e guarda suas características autorais quando vista isoladamente na tela dos seus seguidores. 0 aplicativo, porém, permite e incentiva o usuário (autor ou receptor) a participar da construção de camadas narrativas transdicursivas que se deslocam do "ego" para o "pathos". Em outras palavras, a estética do banco de dados transita justamente entre os dados pessoais/autorais e os dados coletivos (eventuais, temáticos).

Já os artistas que driblam os temas comuns e criam seus próprios \#, conseguem construir narrativas sequenciais autorais únicas, se aproximam mais das narrativas lineares programadas, como visto em Twentysix gasoline stations (1963) e Every building on the Sunset Strip (1966), de Ed Ruscha, e em Learning from Las Vegas (1972), dos arquitetos Robert Venturi, Denise Scott Brown e Steven Izenour, no capítulo 2. Com a grande diferença de que esses pequenos fragmentos isolados também poderão ser renomeados em novos \#, formando novas narrativas completamente dissociadas das narrativas originais. Ou seja, "\#x", " $n$ ” vezes.

No caderno Imageria urbana apresentamos narrativas cujos agenciamentos foram construídos coletivamente. A estética desses ensaios também é resultado da prática coletiva. Em Mapping the collective, Sara Diamond (2011) aponta o desafio do reconhecimento dessa prática artística que tem de estar focada no indivíduo, na medida em que ele é quem decide se determinado tema ou causa vai Ihe interessar ou não. Aumentar as possibilidades de agenciamento é um objetivo fundamental para os coletivos.

Séries como \#parqueminhocao, \#ciclovianapaulista, \#malditosfios dependem do engajamento dos indivíduos com a causa. Segundo Diamond, as linguagens na internet dependem da escrita e esta coordena as ações coletivas de várias práticas, como jogos, SMS, apropriações e novas associações temáticas como as narrativas do Instagram, configurando uma nova dialética de linguagem. A autora vê essas ações coletivas como performances. Dependem de uma auto- organização e da imprevisibilidade da repercussão.

Para Diamond a coletividade é um método de trabalho. Quando aliada ao uso de sistemas tecnológicos utilizados por pesquisadores, designers e educadores, nos deixa perceber o que é essencial em interação social, descartando todo o lado comunicacional. 0 processo interdisciplinar integra homem e máquina por meio da codificação de dados cuja interpretação e metáfora compartilhada faz parte desse "entendimento" da construção coletiva. Todo o processo de agenciamento artístico é reconhecível, valorizando o senso de colaboração. Isso é fundamental para entendermos as redes e os novos mapeamentos que transcendem a linearidade histórica do tempo e espaço e incluem uma outra dimensão em outros planos temporais.

Segundo Victoria Vesna (2007), há uma nova estética emergente, caracterizada pela incorporação de informações e dados disponíveis nas redes nas estratégicas artísticas. A artista e pesquisadora assume a estética de banco de dados vinda da superprodução de informações disponíveis no fluxo das redes:

[...] A estética do projeto depende da manipulação do artista e sua prática em lidar com dados, como ele navega pelos "back bones" (rede de transporte de dados) das redes dos bancos de dados e consegue vislumbrar informações com uma vocação estética para seu projeto [...]. Como a informação é organizada e o que deve ser publicado de forma estética depende do artista-editor. (VESNA, 2007, p.10, tradução nossa).

Coletividade, uso de dados, colaboração e cooperação são partes da natureza dessa nova prática estética. 0 papel do artista não é apenas o de contribuir no tratamento dos dados e nas novas formas de visualização, mas participar ativamente dessa nova prática coletiva entre o artista e sua audiência participativa. Ele tem que pensar em como transformar dados em novas formas de conhecimento: as "metaobras", como define Vesna. 


\section{Considerações finais}

A edição do caderno Imageria urbana representa um recorte da paisagem urbana de São Paulo subjetivada e mediada por imagens no Instagram. Nos propusemos a pensar a imagem mobile e a linguagem poética das redes por meio de imagens. A compilação destas em uma única publicação representa simultaneamente o objeto de estudo teórico e prático desta pesquisa. A apropriação, diagramação e edição de ensaios coletivos e individuais - organizados pelos infinitos "\#x" e pins de geolocalização - configuram um mapeamento iconográfico de alguns lugares da cidade. A partir desse material - e suas imbricações multidisciplinares - levantamos perguntas sobre a natureza e o contexto da imagem mobile. E a singularidade poética dessas narrativas nos mostrou os caminhos para as respostas.

Procuramos discutir e analisar as novas manifestações estéticas da cultura de massa contemporânea nas redes sociais, partindo da premissa da contaminação dos campos da arte, da tecnologia, da comunicação e dos territórios (o espaço geográfico e o ciberespaço) nos quais essas imagens são produzidas e veiculadas.

Com base nos conceitos de Bourriaud (2013), Rancière (2005), Lipovetsky e Serroy (2015), desenvolvemos um aporte teórico para analisar a relação estetizante com o cotidiano. Essa reflexão contribuiu para o entendimento da linguagem poética, dos modos de ver, produzir e distribuir a imageria urbana contemporânea.

Vimos com Couchot (2003) e Beiguelman (2011) como a interpenetração das redes no nosso cotidiano e o uso dos dispositivos móveis, como próteses do nosso corpo, alteram nossa experiência "tecnoestética" (termo criado por apropriação do conceito de tecnestésico de Couchot) e criam uma tensão entre a materialidade e a desmaterialização do espaço físico e o espaço representado por imagens publicadas nas redes, visualizadas nas telas dos celulares, na palma da mão. 
Elencamos a seguir as principais considerações acerca desta investigação:

i. Associamos o novo regime de "imagéité" de Ranciére (2013) à imageria das redes. Dentro desta classificação, essas são imagens metamórficas, potencializadas por novas funções e atribuições inerentes ao ambiente no qual são produzidas, mediadas e distribuídas. A natureza da imagem mobile precisa ser entendida a partir dessa relação simbiótica com a mídia. Ela não é apenas uma fotografia digital, ela é móvel, uma imagem numérica e em permanente deslocamento e transformação (COUCHOT, 2003) e pode ser interpretada em diferentes contextos a partir dos tagueamentos algorítmicos associados a ela. Por esse prisma, estamos distantes da fotografia tradicional. Trata-se de transdiscursos, transformatos, transmídia. A estética e a discursividade narrativa do autor estão transformadas e remixadas em novas narrativas individuais ou coletivas.

ii. A interdependência entre texto e imagem para a construção das narrativas nas redes representa uma das descobertas mais significativas desta pesquisa. A visualização da imagem nas redes está condicionada a uma palavra-chave para que ela seja reconhecida como um dado algorítmico. 0 sinal \# (hashtag) precedido da palavra-chave é a nova legenda do ciberespaço. 0 processo de dados coloca o texto (ou, em outras palavras, os tagueamentos) como questão central da informação e do contexto dessas narrativas. A investigação sobre o uso de algoritmos vinculados às construções narrativas possibilitou a edição e curadoria de uma imageria urbana, matéria-prima fundamental para a prática estética da autora e para o estudo de contexto e natureza da imagem mobile.

iii. Para entendermos as nuances da artemídia e da imagem mobile, dependemos de uma relação de profunda intimidade com as redes e suas possibilidades. Elas, como estrutura conceitual de sistemas de informação e comunicação, assumem um papel fundamental na formação da net art e na poética e estética das narrativas com imagens mobile. Flanagan (2011) e Bastos (2009) apontaram para a importância de focarmos nessa estrutura de codificação e distribuição de informação, condição essencial para que artistas personalizem seus trabalhos a partir da representatividade estética desses dados. Os códigos da internet oferecem infinitas possibilidades na medida em que compilam uma série de dados de APIs. Concordamos com Flanagan que o estudo da experiência do indivíduo ou a estética da tela vem a posteriori e pode ganhar novas interpretações depois de assumirmos que a estrutura dos sistemas de rede determinam os tipos de trabalho criativo. Ou, pelo prisma de Beiguelman (2011), Machado (2002) e Vesna (2007), precisamos conhecer e dominar as ferramentas para subvertê -las a favor da criação e construção de narrativas imagéticas na net art.

iv. A defesa de Steyerl (2009) das produções artísticas feitas com imagens "pobres", de baixa resolução, produzidas especificamente para viajar no fluxo midiático, é uma quebra de paradigma importante para a artemídia, na medida em que devemos assumir o caráter móvel, democrático, muitas vezes efêmero e não institucionalizado dessas narrativas fugidias.

v. Enxergar as narrativas visuais mobile como uma expressão da arte contemporânea. No capítulo Arqueologia das narrativas visuais, destacamos, dentre tantas referências, o trabalho On Broadway de Manovich (2014) (capítulo 2, p. 28), no qual o artista explora o uso de dados aplicado à produção estética coletiva no Instagram para criar um trabalho de net art sem precedentes. Temos um panorama da paisagem, do fluxo de pessoas, dos serviços e hábitos dos cidadãos nova-iorquinos representado por uma estética dos bancos de dados. É a paisagem da cidade do século XXI retratada nas telas, pela estética das redes. Esse trabalho pode ser considerado uma das respostas às investigações desta pesquisa, um retrato que apresenta uma miríade de possibilidades da net art e inclui definitivamente as imagens do Instagram nessa linha evolutiva da arte. On Broadway exemplifica também o novo papel do artista - tema tratado por Vesna (2007) - que passa a ter um novo campo conceitual para novas alternativas de prática artística, a partir de buscas dos códigos, da própria estética de navegação dos aplicativos e das informações extraídas do fluxo das redes. 
vi. O andar como instrumento estético cultuado por Careri (2013) ganha novas possibilidades quando associado ao uso de dispositivos móveis, de produção de imagem, conexão e distribuição contínua. A paisagem urbana de São Paulo está cada vez mais representada por seus cidadãos participantes do jogo estetizante do cotidiano.

A visualização desse atlas radicante ilustrado e fragmentado da cidade aponta para caminhos muito interessantes na medida em que podemos vislumbrar um mapeamento coletivo da cidade, realizado por cidadãos que usam e representam o espaço público e de convívio social por meio de imagens. Nesse sentido, temos uma ferramenta à mão para novos agenciamentos políticos por meio da arte, da produção de linguagem poética. E consideramos o conceito de mapeamento como uma das possibilidades de continuidade desta pesquisa.

vii. Se os dados dinâmicos das redes sociais são a "paisagem" da cultura contemporânea, eles também precisam ser considerados como um contexto (no sentido de lugar) no qual construímos nossa identidade e nos definimos no ambiente virtual, assim como no "networking" do espaço físico. Segundo Paul (2011), vivemos e ocupamos lugares onde nossos corpos continuam sendo objetos físicos. Já no mundo virtual, podemos ser descritos por múltiplos "selfies", em uma realidade mediada. Essa relação não representa uma dicotomia mas uma interação complexa que afeta o entendimento dos corpos e sua identidade on-line. Os dados, diz Paul, "geram informação digital e 'data sets', existem como processo e não são necessariamente 'visíveis' em outros processos visuais, que se manifestam em múltiplas materialidades." (PAUL, 2011, p.111). Esses dados nos fornecem informações de como sujeitos e identidades culturais se manifestam, como estão organizados social e politicamente.

Ao nos debruçarmos sobre a paisagem urbana de São Paulo a partir das representações poéticas das imagens reunidas nesta pesquisa, entramos em contato com a invisibilidade dos dados que estão por trás das construções narrativas.
E constatamos o contexto ubíquo no qual essas narrativas circulam. No ciberespaço e nos mapeamentos geográficos da cidade.

Ao organizar o conjunto de narrativas mobile em uma publicação impressa, o caderno Imageria urbana, permitimos um "ver lento" dessa paisagem paulistana. Interrompemos o fluxo contínuo das redes e criamos uma pausa para permitir a ampliação dessa experiência sensorial. É um convite ao jogo narrativo, à imersão nessas composições e mapeamentos afetivos. E esse jogo nos inspira a novas descobertas e possibilidades de outras construções narrativas, em diversas interfaces de visualização.

O corpo de imagens apresentado no caderno Imageria urbana nos fornece dados preciosos de como os cidadãos interagem com o espaço público da cidade. A pesquisa abrangeu uma pequena amostra de busca algorítmica, em torno de alguns \# (temas ou palavras-chaves) e pins de geolocalização (nomes de bairros, nomes de ruas ou edifícios). Essa estratégia metodológica mostrou-se riquíssima em revelar modos de usar, vivenciar e subjetivar diversos lugares de São Paulo e poderá ser aplicada em outros projetos. Como em um mapa iconográfico da cidade de São Paulo, publicado em um site ou aplicativo, onde cada usuário "posta" imagens do seu bairro, indexadas por \# e pin de geolocalização, contribuindo para a construção de um atlas radicante da cidade.

Por fim, podemos dizer que as narrativas aqui reunidas nos convidam a um permanente deslocamento, a um devir sobre nossa experiência com o espaço urbano por meio da poética das redes. 


\section{Referências}

BASTOS, Marcus. Mapeamento incompleto de algumas geografias celulares. Geografias celulares. Catálogo. Espacio Fundación Telefónica, Buenos Aires, 2010.

BAUMAN, Zygmunt. Modernidade líquida. Rio de Janeiro: Jorge Zahar Editora, 2001.

BOURRIAUD, Nicolas. Radicante. Por uma estética da globalização. São Paulo. Martins Fontes, 2011.

BEIGUELmAN, Giselle. O livro depois do livro. São Paulo: Peirópolis, 2003.

Arte pós-virtual: criação e agenciamento no tempo da internet das coisas da próxima natureza. Disponível em: 〈http://desvirtual.com/web/wp-content/uploads/2015/03/GiselleBeiguelman_arte_pos_virtual.pdf〉. Acesso em mar. 2015.

BEIGUELMAN, G.; LA FERLA. J. Nomadismos tecnológicos. São Paulo: Senac, 2011.

BENJAMIN, Walter. A obra de arte na época de sua reprodutibilidade técnica. Porto Alegre: Editora Zouk, 2012.

BRISSAC, Nelson. Ver do meio - como mato que cresce entre as pedras. Disponível em: 〈http://iconica.com.br/〉. Acesso em jun. 2015.

BRouWS, Jeff et al. (org.). Various small books: referencing various small books by Ed Ruscha. Cambridge: MIT Press, 2013.

CACCIARI, Massimo. A cidade. São Paulo: Gustavo Gili, 2014

CARERI, Francesco. Walkscapes: o caminhar como prática estética. São Paulo: Gustavo Gili, 2013

CASTELLS, Manuel. A Sociedade em rede. São Paulo: Paz e Terra, 1999

COUCHOT, Edmond. A tecnologia na arte. Da fotografia à realidade virtual. Porto Alegre: Editora da UFRGS, 2003

Da representação à simulação: evolução das técnicas e das artes da figuração. In: PARENTE, A. (org.). Imagem-máquina: a era das tecnologias do virtual. São Paulo: Editora 34, 2011

DEBORD, Guy. Théorie de la dérive. Internationale Situationniste, Paris, n. 2, 1958. 
DELEUZE, Gilles. Foucault. São Paulo: Editora Brasiliense, 2005

DELEUZE, Gilles; GUATTARI, Felix. Mil platôs. Capitalismo e esquizofrenia. São Paulo: Editora 34, 1996.

DIDI-HUBERMAN, Georges. O que vemos, o que nos olha. São Paulo: Editora 34 1998.

. Atlas: como levar o mundo nas costas. Disponível em: 〈http://www.museorei nasofia.es>. Acesso em jan. 2016.

DYER, Geoff et al. Como fotografar a rua sem sair de casa. ZUM, São Paulo, n. 1, out. 2011.

FLANAGAN, Mary. Play, participation and art: blurring the edges. In: LOVEJOY, M. et al. (org). Context providers: conditions of meaning in media arts. Bristol, Reino Unido/ Chicago, EUA: Intellect, 2011.

FLUSSER, Vilém. A filosofia da caixa preta. Ensaios para uma futura filosofia da fotografia. São Paulo: Hucitec, 1985

O mundo codificado. São Paulo: Cosac Naify, 2007.

FONTCUBERTA, Joan. Por un manifiesto posfotográfico, La Vanguardia, Caderno Cultura, 2011. Disponível em: <http://www.lavanguardia.com/cultura/20110511/54152218372/ por-un-manifiesto-posfotografico.html>. Acesso em nov. 2015.

FOSTER, Hal. 0 retorno do real. São Paulo: Cosac Naify, 2014

Design and crime (and other diatribes). Londres: Verso, 2003

GONÇALVES, Diana. Entrevista a Richard Grusin. Disponível em: 〈http://Comunicacaoecultura.com.pt/wp-content/uploads/09.-entrevista-a-richard-grusin.pdf〉. Acesso em abr. 2015.

GRAU, Oliver. Media art histories. MIT Press, 2010.

HARVEY, David. Rebel cities: From the right to the city to the urban revolution. Londres: Verso, 2012.

The Crisis of Planetary Urbanization. Disponível em: <http://post.at.moma.org/ content_items/520-the-crisis-of-planetary-urbanization〉. Acesso em mai. 2015.

FOUCAULT, Michel. 0 que é um autor. Bulletin de la Societé Française de Philosophie, no 3, paris, jul.-set. 1969, p. 73-104. Societé Française de Philosophie, 22 de fev. 1969 debate com M. de Gandillac, L. Goldmann, J. Lacan, J. d'Ormesson, J. Ullmo, J. Wah.
HATCH, KEVIN. Something else: Ed Ruscha's photographic books, October, v. 111, 2005.

HOCHMAN, Nadav; MANOVICH, Lev. Zooming into an Instagram City: reading the local through social media. First Monday (Peer-reviewed Journal on the Internet), 18, n. 7, 1 jul. 2013. Disponível em: 〈http://firstmonday.org/ojs/index.php/fm/article/ view/4711/3698>. Acesso em nov. 2015.

INSTAGRAM. About us. Disponível em: 〈http://www.instagram.com/about us〉. Acesso em jun. 2015

JAMENSON, Frederic. Pós-modernism - or the cultural logic of late capitalism. Durham: Duke University, 1995

LEMOS, André. Mídia locativa e territórios informacionais. Disponível em: 〈http:/ www.facom.ufba.br/ciberpesquisa/andrelemos>. Acesso em mar. 2015.

LIPOVETSKI, Gilles; SERROY, Jean. A estetização do mundo. Viver na era do capitalismo artista. São Paulo: Companhia das Letras, 2015.

LOVEJOY, Margot; Paul, Christiane; VESNA, Victoria. Context providers. condition of meaning in media arts. Bristol, Reino Unido/Chicago, EUA: Intellect, 2011.

MACHADO, Arlindo. Arte e mídia, Galáxia, v. 2, n. 4, 2002. Disponível em 〈http://200.144.189.42/ojs/index.php/galaxia/article/viewArticle/1309〉. Acesso en nov. 2015

A ilusão especular. São Paulo: Editora Gustavo Gili, 2015.

MANOVICH, Lev. Exploring urban social media: Selfiecity and On Broadway. Disponível em: 〈http://academia.edu.html〉. Acesso em nov. 2015

Selfie City. Disponível em: 〈http:// selfiecity.net〉. Acesso em jun. 2015.

PAUL, Christiane. Contextual networks: data identity and collective production. In LOVEJOY, M. et al. (org). Context providers: conditions of meaning in media arts. Bristol, Reino Unido/Chicago, EUA: Intellect, 2011.

RANCIÈRE, Jacques. A partilha do sensível: estética e política. São Paulo: Editora 34, 2005.

O destino das imagens. Rio de Janeiro: Contraponto, 2013.

VENTURI, Robert et al. Learning from Las Vegas. Cambridge: Mit Press, 1977. 
SANTAELLA, Lúcia. Linguagens líquidas na era da mobilidade. São Paulo: Paulus, 2007.

SCHÄFFNER, Wolfgang. A revolução telefônica da imagem digital. In: BEIGUELMAN, G.; LA FERLA. J. (org). Nomadismos tecnológicos. São Paulo: Senac, 2011.

SMITHSON, Robert. Um passeio pelos monumentos de Passaic [1967]. Espaço \& Debates, São Paulo, v. 23, n. 43/44, jan/dez 2003.

STEYERL, Hito. In defense of the poor image. e-flux Journal, n. 10, nov. 2009. . Proxy and politics. e-flux Journal, n. 60, dez. 2014. Disponível em: <http:// www.e-flux.com/journal/proxy-politics〉. Acesso em mai. 2015.

VESNA, Victoria (Ed.). Database aesthetics: art in the age of information overflow. Minneapolis: University of Minessota Press, 2007.

VICENTE, Jose Luis de. Armazenando o eu: sobre a produção social de dados. In: Beiguelman, G. e Magalhães, Ana G. Futuros possíveis: arte, museus e aquivos digitais. São Paulo: Peirópolis/ Edusp, 2014, p. 288-301.

VISCONTI, Jacopo. Novas Derivas. São Paulo: WMF Martins Fontes, 2014.

WARBURG, Aby. Histórias de fantasma para gente grande. São Paulo: Companhia das Letras, 2015. . <http://warburg.library.cornell.edu/〉

WENDT, Brook. The allure of the selfie: Instagram and the new self portrait. Institute of Network Cultures, 2014. Disponível em: <http://networkcultures.org/blog/publication/no-08-the-allure-of-the-selfie-instagram-and-the-new-self-portrait-brooke-wendt/>. Acesso em out. 2015. 